\title{
NORBERT BOTH
}

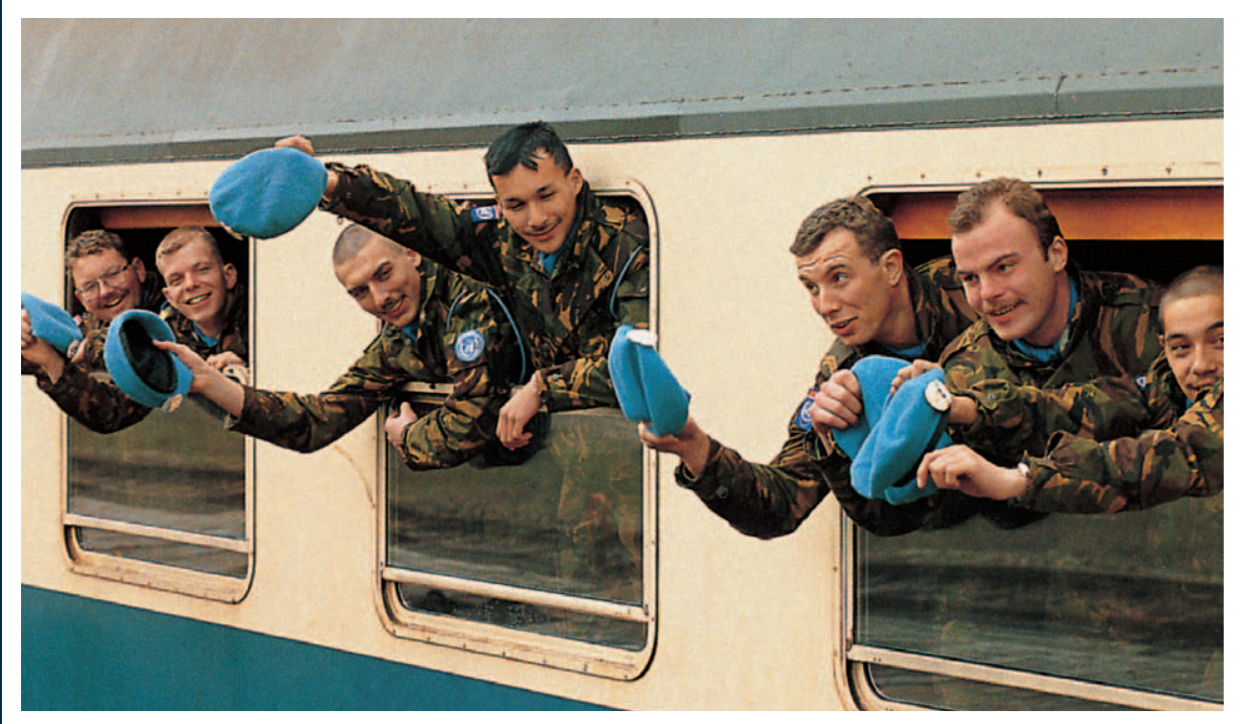

From Indifference

to Entrapment

\section{The Netherlands}

and the Yugoslav Crisis

$$
\text { 1990-1995 }
$$


From Indifference to Entrapment 



\section{From Indifference to Entrapment}

The Netherlands and the Yugoslav Crisis 1990-1995

Norbert Both 
Cover illustration: Dutch military men leaving for Croatia. Photo: ANP, Rijswijk Cover design: Kok Korpershoek [KO], Amsterdam

Lay-out: Magenta, Amsterdam

ISBN 9053564535

(C) Amsterdam University Press, Amsterdam, 2000

All rights reserved. Without limiting the rights under copyright reserved above, no part of this book may be reproduced, stored in or introduced into a retrieval system, or transmitted, in any form or by any means (electronic, mechanical, photocopying, recording, or otherwise), without the written permission of both the copyright owner and the author of this book. 
To Jan and Ada 



\section{Contents}

Preface 9

Abbreviations 13

Chronology 15

Introduction 25

1 The Netherlands and its Foreign Policy System 45

2 An Emerging Challenge, July 1990-June 199169

3 From 'Even-Handedness' to 'Selectiveness' 101

The Dutch EC Presidency, July-December 1991

4 Moral and Political Entrapment 143

International Peace Plans for Bosnia-Herzegovina, 1992-1994

5 Military Entrapment 181

The Commitment to Srebrenica, 1993-1995

Conclusion 225

Bibliography 243

Index 257 



\section{Preface}

This book is based on my PhD thesis from the University of Sheffield, which I successfully defended in May. As I have been employed by the Netherlands Ministry of Foreign Affairs since October 1998, it was arranged that I should offer a copy of the thesis to two separate official investigations that were being conducted in the Netherlands. One of them was the Commissie Bakker, or the Tijdelijke Commissie Besluitvorming Uitzendingen TCBU, a Parliamentary investigation committee set up to assess the domestic decision-making process regarding the deployment of Dutch forces in a number of peacekeeping operations in e.g. former Yugoslavia, Cambodia, Angola and Cyprus (on May 19, 2000). The Netherlands Institute for War Documentation (NIOD), charged with an independent analysis of the events surrounding the fall of Srebrenica, received a copy on May 29, 2000 as well.

The theoretical component of the thesis is represented in the introduction to this book. It covers three sets of literature. The first one deals with the international handling of the Yugoslav crisis. The second represents the contrasting views on the nature of the international system and the role of small states within it, while the third focuses on the foreign policy of the Netherlands. In assembling the empirical component of this book, I used various methodological approaches, including the study of unpublished and public documents, memoirs, interviews, secondary literature and press articles. I would be reluctant to claim that participant observation played an important role, although my perspective on the events covered in this book was inevitably coloured by my time spent as a research assistant for David Lord Owen and my work in the European Affairs Department of the Netherlands Foreign Ministry. 
The core of the primary source material consists of official documents from the archives of the Ministry of Foreign Affairs. The references to the Foreign Ministry's documents have been deleted, given that they only mentioned the files in which they had been found. A full list of the files that were studied is provided in the bibliography. In addition, I was granted access to former Minister of Defence Relus ter Beek's personal papers. While Ter Beek did make use of these papers for his own memoirs, the Foreign Ministry's documents referred to in this thesis are not in most cases available in the public domain. The reasons for not extending my research of the Foreign Ministry's documents to include the (months before the) actual fall of Srebrenica are discussed in the introduction. I am aware I have not seen all the relevant government documents covering the period under discussion (notably Cabinet minutes), but I feel that I have seen sufficient material to be able to provide a well-informed interpretation of Dutch Yugoslavia policy during the period under discussion.

An additional primary source is David Owen's Balkan Odyssey CDROM, which includes several references to Dutch Yugoslavia policy during the period discussed in this book, including a report of a meeting in 1993 between the ICFY co-chairmen and Dutch Foreign Minister Pieter Kooijmans. Use was made too of official letters to Parliament and parliamentary records, as well as some official reports by various institutes, including the UN Secretary General's 'Srebrenica Report'. This book also draws on the growing number of personal memoirs covering the Yugoslav crisis. I also used the statements made by key players during the Public Hearings of the TCBU in the Hague during the period 22 May - 8 June 2000.

On-the-record as well as some off-the-record interviews were conducted with key players. Use was also made of the knowledge gained through the numerous interviews conducted together with Dr Jan Willem Honig for our book Srebrenica, Record of a War Crime. In some cases I received letters from key players explaining their views on particular instances related to the period in which the Netherlands held the EC Presidency in 1991. The opinion polls conducted under the aegis of the Stichting Krijgsmacht en Maatschappij testify to the pro-interventionist domestic mood in which the Dutch decision-making process regarding the military contributions to UNPROFOR took place. 
I dealt with the problem of how to draw a line between knowledge gained as an academic researcher and knowledge gained as a Foreign Ministry official as follows. Upon my arrival in the European Affairs Department, in October 1998, I presented my draft-thesis to the people responsible for the Dutch version of the 'Freedom of Information Act', de Wet Openbaarheid Bestuur. Since then, no new references to unpublished documents have been added to this book.

There are numerous people without whose encouragement and advice this book would not have come about. First of all, I would like to thank Dr Ian Kearns and Professor Stephen George from the Department of Politics of the University of Sheffield. They helped me to channel my enthusiasm for international relations into a successful year (1993-1994) as an MA student and continued to encourage me from then on. I would also like to express my gratitude to the University of Sheffield for providing me with a three-year scholarship from the Basil Hicks Lecture Endowment. I would like to thank Dr John Hawthorne as well as Sue Kelk and Sarah Cooke for their help over the past years.

Between October 1994 and November 1995, I worked for Lord Owen as a research assistant. Apart from Lord Owen himself, I would like to thank Maggie Smart for her warm support during this phase. In London I also met Dr Jan Willem Honig and Dr James Gow, who willingly shared their knowledge about military strategy in general and the Yugoslav war of dissolution in particular, and encouraged me to go on when the road ahead seemed too long to travel. It required the hospitality of Andrew and Bryan Crick, as well as Peter and Ruth Martin, for me to be able to live in London during this period.

Over the years I have had many formal and informal conversations about Western policy regarding the Yugoslav crisis with people from various backgrounds. While I thank them all for their insights, I will only mention by name those with whom I communicated in the specific context of this thesis and who did not pose the condition of anonymity: Commissioner of the Queen Relus ter Beek, Ellen Berends, Ambassador Dr Niek Biegman, Hans van den Broek, Peter Lord Carrington, Ambassador Jan Fietelaars, Harm J. Hazewinkel, Jan Hoekema MP, Bert Kreemers, MajorGeneral Ton Kolsteren, Professor Pieter Kooijmans, Maarten Lak, Prof. Ruud Lubbers, Frank Majoor, Ambassador Muhamed Sacirbey, Herman 
Schaper, General Arie van der Vlis, Dr Joris Voorhoeve, Ambassador Peter van Walsum, and Hanno Würzner. I benefited from conversations with Professor Maarten Brands, who backed up my request for access to the Foreign Ministry's records, and with Dr Bram Boxhoorn, Professor Koen Koch, Dr Dick Leurdijk and Rob Meines.

I would like to thank Peter van Velzen, Ton van Zeeland and the staff of the Foreign Ministry's library for responding with such flexibility to my requests for documentation. Yvonne van Gog of the Rijksvoorlichtingsdienst was kind enough to provide me with compiled sets of press articles. Jacques Leuven, the documentation specialist in the Foreign Ministry's European Affairs Department, deserves thanks for helping to streamline a number of footnotes. I greatly appreciate the fact that my hard-pressed but ever-cheerful colleagues in the European Affairs Department showed interest in what I was doing and enabled me to take some time off during the final stages of writing.

In my immediate surroundings, I am indebted to my grandfather Willem Polderman, who lent me the funds I needed to enroll as an official MA student at the University of Sheffield. My wife Graciella had to cope with the various downsides of years of $\mathrm{PhD}$ work, and I greatly admire her for having consistently encouraged me not to give up. Philippe, many thanks for letting me use your office during the final stages of work. Peter, thanks for applying your whiz-kid talents to solving problems with my 'tupperware computer'. I may have omitted names of people who in reality played an important role in the coming about of this thesis. I apologise and am grateful for their contribution. 


\section{Abbreviations}

CDA Christen Democratisch Appèl (Christian Democrat Party)

CFSP Common Foreign and Security Policy

CSCE

$\mathrm{DAB}$

Conference on Security and Cooperation in Europe

DAV

DGES Directoraat-Generaal Europese Samenwerking, Ministry of Foreign Affairs

DGIS Directoraat-Generaal Internationale Samenwerking, Ministry of Foreign Affairs

DGPZ Directoraat-Generaal Politieke Zaken, Ministry of Foreign Affairs

DVB Directie Veiligheidsbeleid, Ministry of Foreign Affairs

D'66 Democraten '66 (Liberal Democrat Party)

EC European Community

ECMM European Community Monitoring Mission

EPC European Political Cooperation

EU European Union

FRY Federal Republic of Yugoslavia

GAC General Affairs Council: meetings of EC/EU Foreign Ministers

HTK Handelingen Tweede Kamer der Staten-Generaal

ICFY International Conference on the Former Yugoslavia

ICTY International Criminal Tribunal for the Former Yugoslavia

JAP Joint Action Programme, Washington, May 1993 
JNA

MP

NAC

NATO

NIOD

OIC

OSCE

PvdA

QMV

SACEUR

UN

UNHCR

UNPROFOR

VOPP

$\mathrm{VJ}$

VVD

WEU
Yugoslav People's Army (under SFRY)

Member of Parliament

North Atlantic Council

North Atlantic Treaty Organization

Nederlands Instituut voor Oorlogsdocumentatie

Organisation of the Islamic Conference

Organisation for Security and Cooperation in Europe

Partij van de Arbeid (Labour Party)

Qualified Majority Voting (in the EU's Common

Foreign and Security Policy)

Supreme Allied Commander, Europe

United Nations

United Nations High Commissioner for Refugees

United Nations Protection Force

Vance-Owen Peace Plan

Yugoslav Army

Volkspartij voor Vrijheid en Democratie (Conservative Liberal Party)

Western European Union 


\section{Chronology}

1990

23 July Ambassador Albert Nooij warns that Yugoslavia's future as a multinational state is doubtful.

27-28 August Luxembourg Foreign Minister Jacques Poos visits Yugoslavia.

3 October Ambassador Jan Fietelaars succeeds Nooij as Ambassador to Yugoslavia.

22 October GAC instructs Political Committee to 'make recommendations with regard to the appropriate means to encourage the maintenance of [Yugoslavia's] unity in a frame work of democracy.

1991

12-13 February Slovene Prime Minister Lojze Peterle and Foreign Minister Dimitrij Rupel visit The Hague.

27 February US Principal Deputy Assistant Secretary of State for European and Canadian Affairs, James Dobbins, visits The Hague as part of a European tour.

21 March EPC (European Political Cooperation) Troika at level of Political Directors, including Peter van Walsum, visits Washington.

15 May Serbia announces that it will block the rotation of the Yugoslav federal Presidency to the Croat Stipe Mesic.

19-20 June CSCE summit, Berlin. 
20 June

25 June

28 June

28-29 June

30 June - 1 July

1 July

2 July

3 July

7 July

13 July

25 July

27-28 August

7 September

14 September

15 September

17 September

4 October

5-6 October

10 October

18 October
US Secretary of State James Baker consults with parties to the conflict, Belgrade.

Slovenian and Croatian declarations of independence.

Ministerial EPC Troika, including Hans van den Broek, leaves for mediation attempt in Belgrade and Zagreb.

European Council, Luxembourg.

Renewed mediation attempt by ministerial Troika.

Netherlands takes on EC Presidency.

Van den Broek and Van Walsum visit Washington for meetings with National Security Adviser Brent Scowcroft and Secretary of State James Baker.

Embassy in Belgrade warns of departure from Belgrade by Yugoslav Army unit at brigadestrength, with Croatian border town Vukovar as possible area of operations. Brioni declaration.

Dutch border changes proposal distributed to EC partners; rejected out of hand.

France proposes deployment of WEU 'interposition’ force.

EC Foreign Ministers condemn Serbian 'fait-accompli policy'.

First session of EC Peace Conference, chaired by former British Foreign Secretary Lord Carrington, The Hague. Van den Broek receives Croatian Foreign Minister Zvonimir Separovic.

Bilateral German-Italian meeting, Venice.

Netherlands proposes 'lightly armed' WEU force.

Meeting of Lord Carrington, Van den Broek, Croatian

President Franjo Tudjman, Serbian President Slobodan Milosevic and JNA Commander Veljko Kadijevic produces acceptance of principle of recognition of individual Yugoslav republics as possible outcome of negotiations, The Hague.

EC Foreign Ministers applaud agreement of October 4, Haarzuilens Castle, Netherlands.

Van den Broek introduces two-month deadline to negotiations.

Milosevic refuses Carrington's ‘Arrangements for a General Settlement'. 
28 October

8 November

18 November

19 November

26 November

2 December

4 December

\section{9-10 December}

16-17 December

18 December
EC Foreign Ministers threaten 'non-cooperating parties' with 'restrictive measures'.

EC Foreign Ministers announce restrictive measures. Serbian forces take Vukovar.

Memorandum by Director-General for Political Affairs Van Walsum to Van den Broek proposes formal Dutch policy of anti-Serbian selectiveness.

European Christian-Democrat government leaders reach informal consensus on recognition, Stuyvenberg Castle, Belgium.

EC Foreign Ministers introduce 'positive compensatory measures', for Slovenia, Croatia, Bosnia-Herzegovina and (Former Yugoslav Republic of) Macedonia.

German Foreign Minister Hans-Dietrich Genscher confirms seriousness of two-month deadline to WEU assembly.

Intergovernmental Conference, Maastricht, Netherlands.

EC Foreign Ministers decide to go ahead with recognition of independence of individual republics, to take place on January 15, 1992.

Germany announces decision to recognise Croatia and Slovenia.

1992

21 February Security Council adopts resolution 743, establishing UNPROFOR (intended for Croatia only).

Early April Sporadic fighting in Bosnia-Herzegovina turns into open war.

6 April European Community and its member states recognise Bosnia-Herzegovina as independent state.

7 April USA recognises Bosnia-Herzegovina as independent state.

8 June Security Council adopts resolution 758, extending UNPROFOR's mandate to Bosnia-Herzegovina.

6 August ITN broadcasts images of emaciated Muslim prisoners in Serb-run camps. 
11 August

22 August

26-27 August
Clingendael foreign policy analysts Joris Voorhoeve and Theo van den Doel advocate military intervention in International Herald Tribune.

Minister for Development Cooperation Jan Pronk advocates military intervention in Trouw.

London Conference, co-chaired by British EC-

Presidency and the United Nations; agrees principles for settlement for Bosnia-Herzegovina and turns EC Peace Conference into permanent joint EC/UN International Conference on Former Yugoslavia (ICFY).

2 January Professor Pieter Kooijmans succeeds Van den Broek as Foreign Minister.

2 January ICFY presents 'Vance-Owen Peace Plan' (VOPP).

20 January Bill Clinton inaugurated as US President.

10 February US Secretary of State Warren Christopher announces six US steps to help solve the Bosnian conflict.

26 February Ministerial NATO gathering.

17 March Chief of the Defence Staff, General Arie van der Vlis, produces list of deployment options.

16 April Security Council adopts resolution 819, demanding for Srebrenica and its immediate surroundings to be treated as a 'safe area'.

26 April Kooijmans advocates safe areas at GAC, Copenhagen.

2 May Bosnian Serb leader Radovan Karadzic accepts VOPP, Athens.

6 May Bosnian Serb 'Assembly' rejects VOPP (subsequently confirmed in a 'referendum' held on May 15-16).

6 May Security Council adopts resolution 824, expanding the safe area policy to include a total of six Bosnian towns.

7 May Meeting Kooijmans-Christopher at Netherlands Embassy in Bonn, Germany.

19 May PvdA/CDA parliamentary motion calling upon the government to prepare the airmobile brigade for operations in Bosnia.

22 May Joint Action Programme (JAP), announced by the USA, UK, France, Russia and Spain, Washington D.C. 
4 June

18 June

22 June

29 July

9 August

10 August

17 August

25 August

2 September

7 September

7 November

9 November

12 November
Security Council adopts resolution 836, mandating UNPROFOR to deter attacks against the safe areas. Security Council adopts resolution 844, authorising additional deployment of 7600 troops under the light option'.

European Council summit, at which Netherlands pledges a logistical battalion in support of the Security Council's safe area policy, Copenhagen.

Kooijmans protests against ICFY Plan for a Union of Three Republics ('Owen-Stoltenberg plan') in letter to Belgian EC Presidency.

Germany lets it be known that it has reservations about the plan for a Union of Three Republics.

Defence Ministry is informed that UN assignment for logistical battalion is maintenance of former EastGerman equipment to be used by Pakistani UNPROFOR battalion.

Minister of Defence, Relus ter Beek, is advised to 'switch' offer of logistical battalion to airmobile battalion.

ICFY co-chairmen pay separate visits to German Foreign Minister Klaus Kinkel and Kooijmans.

Dutch official tells Under-Secretary-General for Peacekeeping Operations Kofi Annan that the Netherlands remains prepared to participate in safe area operation with battalion of airmobile brigade, UN HQ, New York. Ter Beek formally commits battalion of airmobile brigade in meeting with UN Secretary-General Boutros Boutros-Ghali, UN HQ, New York; meets members of US administration, Washington.

Kinkel and French Foreign Minister Alain Juppé launch 'EU Action Plan' in letter to Belgian Presidency

Ter Beek and Commander of Land Forces, Lt. General Hans Couzy, join advance party of Netherlands

Defence Ministry in Zagreb, Croatia, where options for deployment of airmobile battalion are discussed with UNPROFOR commanders.

Cabinet formally decides to deploy airmobile battalion. 
22 November

30 November

1-2 December

6 December

9 December

11 December

29 December

\section{4}

19 January

27 January

1 February

April

12 May

22 August
Kooijmans tells EU colleagues that he accepts that principles agreed at 1992 London Conference have 'disappeared from sight'.

Bosnian Prime Minister Haris Silajdzic tells Kooijmans that Bosnian government is prepared to fall back on a settlement that awards it one third of the territory of Bosnia-Herzegovina.

Army's Director of Operations, Lt. General Ruurd Reitsma, faxes from Zagreb report and recommenda tion on Srebrenica mission to Lt. General Couzy, who forwards it to Defence Staff.

Netherlands expresses its 'concern' to EU partners about the wish of the Bosnian government to draw in the east-Bosnian enclaves into its future republic. Minister of Defence Ter Beek meets with US Secretary of Defence Les Aspin in margins of NATO Defence Planning Council.

EU Foreign Ministers declare they regard as legitimate the Bosnian government's demands for one-third of the country and access to the sea.

Kooijmans and Kinkel send a joint letter to Bosnian President Alija Izetbegovic, urging Bosnian Muslim forces to refrain from attacks against Bosnian Croat settlements.

Boutros-Ghali received by Prime Minister Ruud Lubbers and other Cabinet members, The Hague. Dutch units depart for Srebrenica The Second Chamber's permanent committees for Foreign Affairs and defence reconfirm their consent to deployment of the airmobile battalion.

Five Dutch military observers taken hostage by the Serbs in retaliation for the use of NATO air power over the safe area of Gorazde.

Ter Beek visits Srebrenica.

Ter Beek's successor as Defence Minister, former Clingendael analyst Joris Voorhoeve, visits Srebrenica. 
18 October Second Chamber's Permanent Committees for Foreign Affairs and Defence are briefed by the army's DeputyDirector of Operations, Brigade-General Ton Kolsteren, about the limited possibilities for evacuating Dutch soldiers from Srebrenica if the need were to arise.

1995

25 May

Air strikes against Pale ammunition dumps in reaction to violations of Total Exclusion Zone around Sarajevo (Bosnian Serb heavy weapons were supposed to have been withdrawn to a distance of at least $20 \mathrm{~km}$ from the centre of Sarajevo, or be placed in Weapons Collection Points monitored by UNPROFOR).

26 May $\quad 400$ UN personnel taken hostage by Serb forces in retaliation for air strikes against Pale ammunition dumps.

3 June Bosnian Serbs take OP Echo (Dutch observation post on the southern perimeter of the Srebrenica safe area).

18 June Last UNPROFOR hostages released by Serbs.

11 July Fall of Srebrenica, followed by mass killings of Muslim men by (Bosnian) Serb forces.

28 August Last British troops withdrawn from the Gorazde safe area; Dutch Cabinet said to be considering a Dutch troop deployment as replacement. 


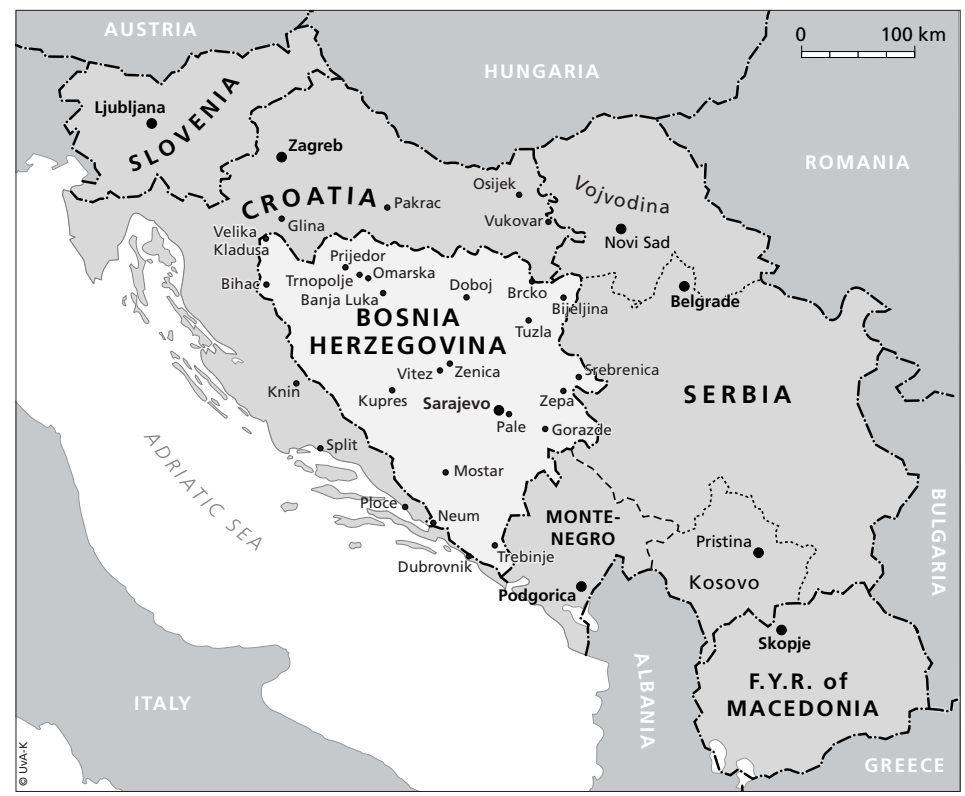

B

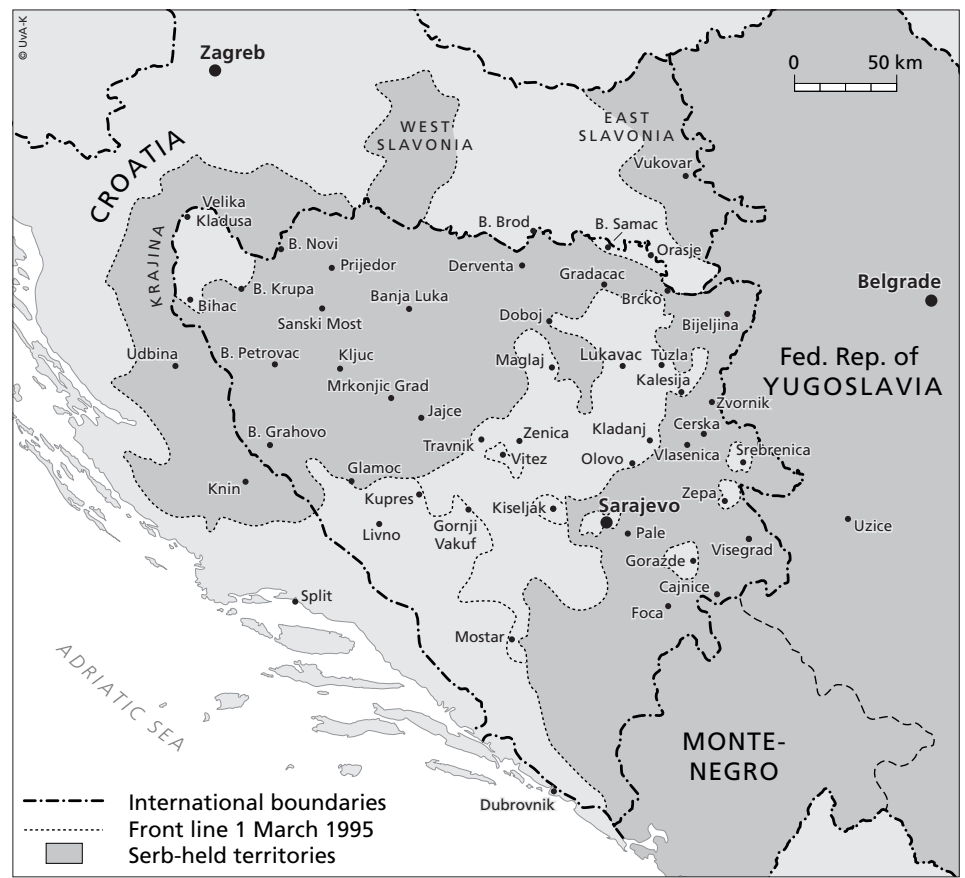




\section{C}

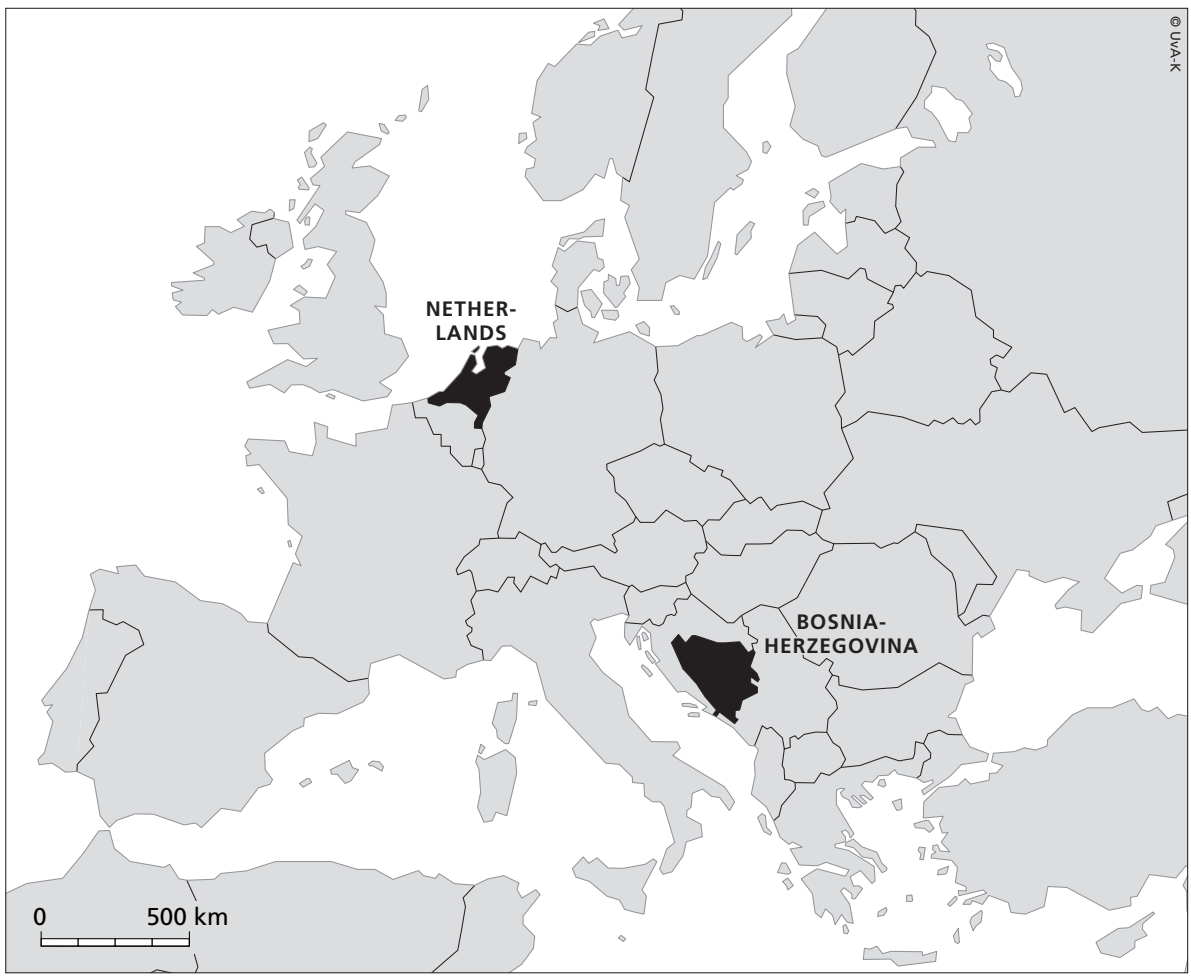





\section{Introduction}

'Srebrenica' will long remain a symbol for the mismatch between the great ambitions and limited margins of Dutch foreign policy with regard to the Yugoslav crisis between July 1990 and July 1995. In July 1995 (Bosnian) Serb forces attacked the enclave which had been declared a 'safe area' by the United Nations Security Council and overran the Dutch peacekeepers who had been stationed there precisely to deter such attacks. Subsequently, Serb soldiers and paramilitaries murdered some seven thousand Muslim men. For the Netherlands, the fall of Srebrenica and the subsequent massacre and, in particular, the feeling of impotence that had accompanied the events as they unfolded, constituted the nadir in five years of involvement in the Yugoslav crisis.

This book is not so much concerned with the fall of Srebrenica itself. There are three reasons for this. First, a substantial body of literature on the fall of Srebrenica is now available (and more is being produced), including a book authored by Jan Willem Honig and myself to which this book would have little to add. ${ }^{1}$ Second, I am employed in the Dutch Foreign Ministry's European Affairs Department as a desk officer with responsibilities covering a wide range of issues regarding the former Yugoslavia. Given the need for a clear demarcation line between knowledge obtained as an academic and the knowledge acquired as an official, it seemed wise to limit the period covered by this book to a period well before my entry into the Foreign Ministry, thus excluding e.g. the 1999 Kosovo crisis. The third reason for confining the period covered by this book to the years 1990-1995 involved the perceived need for consistency in the use of primary source material. The Netherlands Ministry of Foreign Affairs was kind enough to allow me to study its official records 
covering the period of 1990 until well into 1994, by which time the parameters for the Dutch involvement in the events of July 1995 had been firmly set. The documents covering the actual fall of Srebrenica had already been claimed by the official Srebrenica investigation by the Netherlands Institute for War Documentation (NIOD), whose work I did not seek to interfere with. Fortunately, former Minister of Defence Relus ter Beek gave me access to his personal archives, which meant that I could also study the Defence Ministry's perspective on the decision-making regarding the Dutch deployment in Srebrenica. Access to these archives, numerous interviews and a year of research carried out on behalf of David Lord Owen in 1994 and 1995 helped me to give substance to this work.

Dutch readers in particular may feel that the absence of a discussion of the domestic debate in the Netherlands following the fall of Srebrenica is an omission. This debate in my view constitutes a research topic in itself, perhaps primarily for social historians and social psychologists. 'Srebrenica' was a formative experience, one that will influence Dutch foreign and defence policy for years to come. A comparative study of pre-Srebrenica Dutch foreign policy and post-Srebrenica foreign policy might, therefore, be interesting. However, it is with a great sense of relief that I leave such ambitious tasks to the NIOD and the parliamentary commission investigating the Dutch contributions to recent peacekeeping operations.

While this book does not shed a new light on the actual fall of Srebrenica or its impact on Dutch society, it is very much concerned with the road that led the Netherlands to become a player in this event. It retraces the steps taken by the Netherlands in response to the Yugoslav crisis from a year before armed conflict erupted until the fall of Srebrenica in July 1995. It provides an analysis of the intentions and the substance of Dutch Yugoslavia policy and examines whether specific outcomes of the international community's policy towards this crisis can be attributed to the Dutch foreign policy process. The answer to this last question has implications for the answer to a much broader one, namely whether a nongreat power like the Netherlands can exert influence on international affairs, as this book argues is indeed the case.

Before going on to the question of small-state influence, let us briefly discuss why one would treat the Netherlands as a smaller state in the first 
place. After all, the divide between great powers and small powers, which seems so clear-cut in theory, is difficult to define in reality. As one writer on small states puts it: 'Until now there have been as many definitions as authors.'2 There is no point in denying, however, that in the arena of the Yugoslav crisis between 1990 and 1995, there was an obvious difference between what the USA and the Netherlands each could have achieved had the two countries' ambitions been exactly the same. If we define small states, as Robert Keohane has done, by what it is that they cannot achieve - but what great powers can - then the theoretical implications of this study become relevant for the analysis of the foreign policies of the great majority of states currently operating in the international system. ${ }^{3} \mathrm{Keo}-$ hane defines a great power as a 'state whose leaders consider that it can alone exercise a large, perhaps decisive impact on the international system.' States whose leaders recognise that they cannot exercise such an impact single-handedly, or not at all, are 'secondary', 'middle', or 'small' powers. On this basis, the Netherlands ranks as something between a small power and a secondary power, or as former Dutch Defence Minister Joris Voorhoeve once put it, as a 'pocket-sized medium power.' ${ }^{5}$ This brings us back to the question of whether and, if so, how small states can influence international affairs.

There is a mainstream position in the academic field of international relations (IR), called Realism, that sees no real role for smaller states. 'Realists' regard the international system as an 'unregulated competition of states', in which power is the main differential. ${ }^{6}$ In the absence of a central arbitrator, powerful states are better placed than smaller states to acquire power. As the father of 'Structural Realism', Kenneth Waltz, puts it: 'In international politics, as in any self-help system, the units of greatest capability set the scene of action for others as well as for themselves.' In other words, smaller states are in the undesirable position of being compelled by the external environment to make foreign policy in the same way as great powers, i.e. on the basis of rational calculations of interest, despite lacking the intrinsic weight to exert a substantial influence on the international system. However, there are at least four sets of literature, relevant to this book's topic, that question these mainstream Realist premises, the first and second of which leave room for small-state influence in international relations. The third and fourth stress the importance of domestic influences on foreign policy, suggesting that the international system does not by definition compel states to act similarly. 
First, there is a small body of literature which accepts the Realist world view of a competitive international system and the rationality of the state, but argues that small states can be influential nevertheless. This 'dissident' Realist literature argues that small states must 'learn to operate successfully within the arena of Great Power conflicts.' In essence, there are two ways for small states to do this. First, they can mobilise their internal power resources in order to project an image of relative power and exploit the notorious difficulty of defining 'power': the sum of material (military, economic and technological) and immaterial (e.g. morale, ideology) resources, in which case it is quantifiable to an extent, or 'the ability to influence others' behavior.' Secondly, small states may seek to mobilise the power of others. As Michael Handel puts it: 'The diplomatic art of the weak states is to obtain, commit and manipulate, as far as possible, the power of other, more powerful states in their own interests. ${ }^{10}$

A second, more fundamental challenge to the Realist perspective on small states is posed by the Liberal world view that stipulates that the international system can be made more benign through human progress, international cooperation and scientific modernisation. ${ }^{11}$ Liberals believe in the possibility, even logic, of international cooperation on the basis of shared interests, rules, norms, values and ideas. ${ }^{12}$ While they do not focus especially on the role of small states, Liberals are by definition more sympathetic than Realists to the idea that a smaller state like the Netherlands may be 'small yet influential'. ${ }^{13}$

Within the Liberal strand, Neoliberals focus on international cooperation through international 'regimes'. International regimes were defined by the contributors to a special edition of International Organisation in 1982 as 'sets of implicit or explicit principles, norms, rules, and decision-making procedures around which actors' expectations converge in a given area of international relations. ${ }^{14}$ Regimes may enhance the influence of smaller states in two ways. First, regimes enable individual members to pursue their foreign-policy aims collectively. Second, through their common rules, procedures and norms, regimes can level out some of the differences between the bigger and smaller regime-members. Helpful in understanding the impact of regimes on individual states is a description given by The Economist of the international constraints exercised on the UK, in particular by the EU: 'It remains true that the EU has a much wider and deeper authority than any of the other international bodies Britain is a 
member of. NATO confines itself to security; it has no court and issues no laws. The WTO [World Trade Organisation] can overrule government policy, but its competence is limited to trade. By contrast, European law already affects a wide range of activities from agriculture to employment legislation to the environment. By acceding to the EU, Britain accepted that European law outranks British law.' ${ }^{15}$

The third and fourth approaches challenge Realism's assumptions that the external environment is the most important determinant of a state's foreign policy and that the state is a 'rational actor' operating on the basis of carefully calculated national interests. Instead, it is argued that domestic and 'irrational' factors play a vital role in the making of foreign policy.

The 'bureaucratic politics' model as sketched by American authors like Herbert Simon, Morton Halperin (currently a senior official in the US State Department) and Graham Allison stresses the disaggregated nature of the state. What seem to be the strategies of a state are in fact the outcomes of bargaining processes involving many formal and informal participants. 'The participants, while sharing some images of the international scene, see the world in very different ways. Each wants the government to do different things, and each struggles to secure the decisions and actions he thinks best. ${ }^{16}$ From this perspective the government is neither a unitary nor a rational actor. Rather, policy is determined by the conflicts fought, the compromises struck and the coalitions built among bureaucracies, officials, as well as non-governmental pressure groups.

From the bureaucratic-political perspective it is only natural that actual foreign policy does not match the preferred option of any of the individual actors involved in the policy-making process. Moreover, there is a risk that the foreign policy agreed upon by the participants involved is not just different, but is actually more ambitious than any of the participants had intended it to be. This phenomenon has been termed 'coalition logrolling. ${ }^{17}$ Instead of the various interests being bargained into a compromise, they coagulate. Participants agree to go along with a policy that is being pushed by another participant on the condition that their own core interests and views are also included in the proposed policy.

When a policy has finally been agreed, its implementation often looks different from what either supporters or opponents of the policy had 
expected. The difference between the policy as formulated and the policy as implemented is known as 'slippage'. In their enthusiasm, supporters 'may go beyond the spirit if not the letter of the decision', while the opponents 'will manoeuvre to delay implementation, to limit implementation to the letter but not the spirit, and even to have the decision disobeyed'.18

A fourth approach focuses on domestic agreement, rather than disagreement. Such agreement may occur as a result of shared ideas and beliefs. At the most fundamental level of such ideas and beliefs, Judith Goldstein and Robert Keohane identify world views, or 'conceptions of possibility. ${ }^{19}$ Religions may provide world views, as may ideologies. In the broad context of these world views, one can find 'principled beliefs' or 'normative ideas that specify criteria for distinguishing right from wrong and just from unjust. The views that "slavery is wrong", that "abortion is murder", and that human beings have the "right of free speech" are principled beliefs. ${ }^{20}$ Ideas and beliefs, if they are shared by the foreign-policy élite, serve to limit the number of viable policy options, even if the policymakers attempt to ground policy in calculations of the national interest. The reason is that ideas, beliefs, principles and values limit the conceptions of what is rational and in the interest of the state. A policy that would have been chosen, for example, had a mathematically 'objective' calculation of interest been made may be rejected because of a shared notion of a state's historical tradition. It is, moreover, conceivable that the dominant culture prescribes that policy should not even be interest-based but seek to further the promotion of certain ideals.

Against the background sketched above, this book sets out to test the following hypothesis regarding Dutch Yugoslavia policy during the period 1990-1995: the Netherlands, initially disinterested, was at times a strikingly influential player that, however, ultimately failed to avoid entrapment in the Bosnian war. Entrapment, in turn, was caused by the combination of an increasingly competitive external environment and a domestic policy process that was ill suited to such an environment, given that it was driven by moral concerns and hampered by bureaucraticpolitical conflict.

The main hypothesis can be subdivided into four simplified arguments. Firstly, during the entire period under discussion, the Netherlands exercised more influence on the international environment than Realists 
would think possible. Secondly, Dutch foreign policy was even more influential during periods when the international environment surrounding the Yugoslav crisis was marked by a shared desire for cooperation, along the lines of the (Neo)Liberal world view sketched above. Thirdly, a thorough understanding of the Dutch role must address domestic factors, given that these were sometimes more important determinants than the external environment. Finally, underlining that 'influence' and 'success' do not always go hand in hand, it is argued that the Netherlands increasingly 'entrapped' itself in the Bosnian war and the Yugoslav crisis, as symbolised and exacerbated by the static presence of Dutch troops in the isolated Srebrenica enclave in eastern Bosnia during 1994 and 1995.

Given that the term 'entrapment' is not usually taken to mean 'selfentrapment', a brief explanation of the term as it is used in this book may be useful. In his famous article on alliance politics, Glenn Snyder defined 'entrapment' as 'being dragged into a conflict over an ally's interest that one does not share, or shares only partially. ${ }^{21}$ For Snyder, entrapment is one of the 'principal bads' of alliance-membership. ('Abandonment' is the other principal bad, which occurs for instance when an ally realigns with the alliance's opponent, dealigns or fails to give support when the other allies most need it.) The words 'being dragged into' show that Snyder sees entrapment as a third party tactic, even though this party is an ally and not an outright military opponent.

In the case of the Dutch involvement in the Yugoslav crisis, we will adapt and expand Snyder's concept of entrapment. The idea is to take into account domestic politics and to encompass non-military aspects of entrapment. First, I shall introduce the variant of 'self-entrapment', or entrapment as the product of one's own policy. This is not to suggest that an actor will actively and consciously seek his own entrapment, but it does mean that a strongly committed or highly ambitious actor by the very nature of his own behaviour risks finding himself trying to cross a bridge too far. In this sense, entrapment encompasses such notions as 'overstretch' and 'overcommitment'.

Entrapment does not need to be understood in a literal military sense only. In the context of Dutch foreign policy regarding the Yugoslav crisis, I would like to introduce the notions of 'moral entrapment' and 'political 
entrapment', which refer to commitments which could neither be kept nor withdrawn. 'Moral entrapment' refers to instances where an actor commits himself rhetorically to certain moral values and principles at stake, only to discover that he must either moderate the rhetoric and risk losing his reputation for moral virtue, or maintain the rhetoric and thus further raise the expectations. Moral entrapment may develop into, or be augmented by, 'political entrapment' when an actor builds upon his rhetorical concern by making material commitments that cannot be withdrawn without an unacceptable loss of face, nor be kept if international support is not forthcoming. If an attempt is subsequently made to honour the commitment despite the absence of concrete international backing, one risks becoming overstretched and isolated. When the political commitment includes a military component, military entrapment lurks in the shadows of the initial, home-made moral and political entrapment.

Translating theory into reality, the literature on the Yugoslav conflict seems to suggest that the environment in which international policy was made between July 1990 and July 1995 was initially predominantly cooperative in nature, but became increasingly competitive. British military analyst and Balkans expert James Gow speaks of 'a cooperative approach to dealing with problems of international security' at the end of the Cold War. In that context, 'Yugoslavia became a laboratory rat in experiments of collective international diplomacy.'22 On the other hand, each of the multilateral bodies at work in the management of the Yugoslav crisis was 'essentially subject to the will of its member states, or at least of the most powerful and influential ones'. Also, despite an 'aspiration to work multilaterally', there were at times 'strikingly different attitudes and views on certain crucial issues', which 'occasioned bitter disputes at certain points. ${ }^{23}$ Given that the external environment influences individual states' foreign policies, it is important to recognise that the environment in which the Netherlands tried to play a role in the management of the Yugoslav conflict during the years 1990-1995 was not constant.

From the perspective of a smaller member state of the EC - European Union following ratification of the Treaty on European Union by all member states in November 1993 - the environment of 1990 and 1991 was comparatively cooperative and benign. During this period the Europeans were working, as Gow puts it, 'in the spirit of European Political 
Cooperation, in which, as far as possible, the member states of the EC coordinated their foreign policies.'. ${ }^{24}$ Gow's argument is supported by his French Counterpart, Olivier Lepick, who explains that in this 'first phase' France 'tried to promote its objectives through international organisations such as the EC and then the UN, hoping to reach a "legal" solution to the crisis. ${ }^{25}$ However, by mid-1993, as patience with multilateral diplomacy was wearing thin, multilateral cooperation through the EC and the UN increasingly had to make way for inter-state competition and ad-hoc alliances such as the Joint Action Programme and the Contact Group. In May 1993 five countries came together on an ad-hoc basis and formulated the 'Joint Action Programme' which involved the creation of 'safe areas' in Bosnia-Herzegovina. Three of the programme's signatories, France, Britain and Spain, were member states of the EC. Nevertheless, the remaining nine member states had been left out of the initiative and were presented with a fait accompli. According to David Owen, the EC representative and co-chairman of the ICFY, 'it was galling for other EC nations to have these crucial issues pre-empted; yet sometimes the need for quiet decisive action and secrecy will necessitate a smaller group of EC countries taking their responsibilities on national shoulders. ${ }^{26}$ This view was echoed by Lepick, who argued that the international diplomacy surrounding the Yugoslav crisis entered a 'second phase' when 'multilateral approaches seemed hopeless', and France 'favoured an opportunistic coalition with its traditional partners in order to end the violence in the region, an orientation leading to the creation of the so-called "Contact Group" of five countries. ${ }^{27}$

Judging by the number of substantive comments made in the literature regarding the role of the Netherlands, it would seem that the impact of Dutch foreign policy was greater in the early cooperative environment than in the subsequent competitive environment. Regarding the Dutch EC Presidency of July-December 1991, Gow quotes a British official as saying that it was the 'strong Dutch Presidency that made things happen'. Gow explains that the Dutch Presidency was in some respects 'extremely important' and constituted a 'leading element in galvanising EC efforts'.28 Viktor Meier, whose editorials in the Frankfurter Allgemeine Zeitung were important catalysts in shaping German public opinion during the early phase of the Yugoslav crisis, echoes Gow's view to some extent. According to Meier, Dutch Foreign Minister Hans van den Broek dominated negotiations in July 1991 between the Troika of EC Foreign Ministers and the 
various Yugoslav parties (the Troika consists of the Foreign Ministers of the preceding, current and incoming EC/EU Presidencies). Meier even goes so far as to question 'to what extent Van den Broek, who was in the lead here, thereby operated in harmony with the opinion of the assembled EC-states'. ${ }^{29}$ Laura Silber and Allan Little confirm that Van den Broek was a 'domineering' figure in the EC-chaired negotiations of July 1991.30

While these authors all argue that the Dutch EC Presidency played an important role in 1991, other comments seem to indicate that the impact of Dutch policy was strong partly because it represented the interests of a greater number of actors than just the Netherlands. Meier argues that the 'Dutch Foreign Minister acted as the representative of that group of states that from that moment on consequently tried to monopolise Western Yugoslavia policy and whose primary political goal was the reconstruction of Yugoslavia and then to a certain degree the protection of Serbia, as the successor to the lost Yugoslavia, so to speak. ${ }^{31}$ Susan Woodward, in turn, agrees that Dutch Yugoslavia policy cannot be understood in isolation from the wider institutional context and argues that it was coloured by the Netherlands being an 'adamant' supporter of NATO. ${ }^{32}$

Much less attention is paid to the role of the Netherlands and its Foreign Minister(s) after the end of the EC Presidency of 1991. For the most, part the literature focuses on a small number of so-called countries of significance: the USA, the Russian Federation, Britain, France and Germany (the members of the Contact Group set up in 1994). One of the few substantive references regarding Dutch policy concerns the role of the Dutch delegation at the UN EC-hosted London Conference of August 1992 where, according to Silber and Little, it was at the insistence of the Dutch that the EC drafted a tough anti-Serbian declaration. It appears the delegation had threatened it 'would walk out' of the Conference together with the Bosnian delegation if such a declaration were not proposed by the EC. ${ }^{33}$ With regard to the period of 1993-1995, the Netherlands only crops up in the literature in lists of troop contributing countries and similar statistics, but Dutch policy as such is no longer a subject worth mentioning, let alone analysing. While the fall of Srebrenica briefly shifts the focus of the literature back onto the Netherlands, the perceived role of the country is essentially a passive one, with the presence of Dutch peacekeepers in the enclave presented almost as if it were an accident of history, not the outcome, at least in part, of Dutch foreign policy. Not Gow or 
Woodward, nor Silber and Little, for instance, devote any attention to the question of why it was Dutch troops, and not the troops of another country, that were deployed in this UN Security Council-declared safe area.

Apparently, the constraints exercised by the competitive environment between 1993 and 1995 are perceived to have been so tight that the foreign policy of the Netherlands as a smaller state is no longer worth analysing. The literature also seems to indicate that the growing competitiveness of the international environment was the determining cause of the decline in Dutch influence. A probable additional factor was the loss of what one could term the 'position power' inherent in holding the EC Presidency. However, the problem with addressing Dutch Yugoslavia policy as a mere reflection of the demands imposed upon the country by the international environment is that it easily becomes a self-fulfilling prophecy: the Netherlands lacked impact because the environment was great-power oriented and the Netherlands is not a great power. It overlooks the possibility that even in a competitive environment a non-great power may know very well how to promote its interests and views. In addition, such an approach all too easily denies responsibility for policyfailures by smaller powers by explaining them as instances where (perceived) great powers did not exercise leadership. In the specific case of Dutch Yugoslavia policy, a top-down, environment-oriented approach certainly cannot help us to understand how and why the Netherlands became entrapped through its military presence in Srebrenica. By treating smaller states as helpless pawns, the general literature seems to have over-generalised international diplomacy regarding the Yugoslav crisis during the years 1993-1995 and overlooked the possibility for small states to have an impact on international affairs. This raises the question, finally, of which strategies are available for smaller states to exert influence in international affairs.

To speak of foreign policy strategies suggests two things. First, that governments try to act in the conscious pursuit of certain foreign policy goals (despite the objections raised by the bureaucratic politics approach) and, second, that foreign policy is more than just a 'reflection' or 'derivative' of the demands imposed upon a country by the international system. Rather, it constitutes both a state's adaptations to the international system and its attempt to shape the structure of that system according to its own interests and values. ${ }^{34}$ It is said that smaller states not only share 
the ambition of the great powers to shape the international system, but possess a certain ability to do so.

The literature on small states identifies two 'kinds' of strategies which small states may apply in order to influence international relations. The first are best described as Realist or competitive strategies, the second as Liberal or cooperative strategies. It is important to note that the distinction between the two kinds of strategies does not concern the concept of self-interest. Neoliberalism incorporates the idea that self-interest is an important motivation for cooperation. From a Liberal perspective there is a sound rationale for smaller or weaker states to be progressive in their foreign policy. Since they cannot, ultimately, win in an adversarial international system, it is in their interest to 'depoliticise' international relations by setting moral examples, promoting international interdependence and the rule of law. ${ }^{35}$ The main distinction between small state Realists and small state Liberals, therefore, concerns a difference in interpretation of what is in the interest of the small state, namely whether to accept the adversarial international system as a given and compete in it or to promote the creation of a more benign one.

Small states might compete in the existing system by mobilising their domestic resources in order to project an image of relative power or an image of usefulness as a host to economic, cultural, or political activities that are of international interest. Particularly the 'development of their own military power enables them, under certain conditions, to improve their bargaining position'. ${ }^{36}$ Furthermore, power is often 'issue-specific', which may be an important advantage to a small state with regard to situations where it deems an issue very important while a great power does not. Under these circumstances the small state may be more focused, better prepared and more determined than the great power to achieve a particular outcome and may therefore more successfully translate domestic power into 'behavioural' power and come out as the 'winner' in a conflict or in a negotiation with a greater power. ${ }^{37}$

Although 'weak states can achieve much in the conduct of foreign policy through the mobilisation of internal sources, their relatively low strength potential clearly limits their manoeuvrability. ${ }^{38}$ Small states 'rely much more heavily on external strength. ${ }^{39}$ The most important strategy in a competitive system, therefore, is alliance-membership. Subsequently, 
various strategies are available for the smaller allies to mobilise the most powerful states within alliances. ${ }^{40}$ Essentially, the choice is between a positive and a negative approach. In the first case one adopts a 'loyal ally' strategy. Alternatively, one adopts a 'critical ally' strategy.

The loyal ally seeks to gain influence by supporting the great power morally, politically and militarily at important moments. Having thereby confirmed one's (self-)image of loyalty, the small state will seek a reward, for instance the right to have its policy preferences taken into consideration by the great power. Sometimes a loyal ally is seen as 'superloyal'. In this case 'a small state allied with, or otherwise oriented towards, one or the other of the superpowers clearly demonstrates that it will go along with any of the Superpower's values, wishes and actions (and often go even further)... being more religious than the Pope. ${ }^{31}$ Particularly during the 1960s, Dutch academics argue, the Netherlands was a superloyal ally of the USA. ${ }^{42}$

Alternatively, the small ally may seek influence by being a nuisance. It can criticise, obstruct, or even try to blackmail the great power. One important reason for adopting this kind of approach is what one might call the risk of influence-inflation through consistent loyalty. To be perceived as a great power's client may seriously restrict a small state's freedom to manoeuvre in relations with other states. Some Dutch authors argue that the Netherlands by being critical of America's foreign policy regarding South-East Asia, Southern Africa and Central America in the 1970s gained, rather than lost, influence..$^{43}$ The critical ally may go beyond mere criticism of the great power's policy and become an 'unreliable' ally. Through an unreliable ally strategy, a (small) state hopes to gain influence through what are essentially blackmailing tactics. It can demand compensation, either for supporting the great power's policy or for refraining from actions that would run counter to the interest of the great power. ${ }^{44}$ In the extreme case, the unreliable ally could threaten dealignment or even realignment in order to make the great power meet its demands. Another type of ally that tries to gain primarily by demanding concessions from the alliance is the 'impotent' ally. This strategy best shows the potential power that flows from weakness. Ultimately, by threatening to collapse if the great power does not give greater support, the great power may be forced to come to the aid of the small ally, even if it is fearful of an entrapment exercise. ${ }^{45}$ (Not to help the small ally may have serious 
consequences for the credibility of the great power's leadership.) The 'aggressive' ally, finally, seeks influence by playing up 'its ability to start a conflict'. ${ }^{6}$ The aggressive ally will threaten or actually attempt to 'entrap' the great power into a conflict for interests that are not necessarily those of the other allies.

According to the Liberal world view, a small state may apply various strategies to promote the creation of an international system that is less competitive than the present one. Through 'normative strategies', a small state may strive for new, 'generally accepted moral codes in order to contain the role of violence or the threat of it'. ${ }^{47}$ In other words, the small state seeks a qualitative change of the international system by promoting wide acceptance of higher moral standards that make armed conflict morally unacceptable. Alternatively, a small state can apply 'strategies of law and order'. With this kind of strategy, the small state seeks to contain, rather than eliminate, the roots of armed conflict. By promoting as widespread an adoption as possible of international legal standards or obligations associated with membership of international organisations, the small state attempts to raise the cost of initiating armed conflict by making it illegal and therefore punishable. ${ }^{48}$ In short, while normative strategies are geared towards broadening international 'moral codification', strategies of law and order promote wider legal codification.

'Demonstration politics' is recognised as an important normative strategy. This is 'the demonstrative announcement by a state that it wishes a particular principle to be adhered to. With this demonstrative announcement the small state wants to highlight norms that it wishes to be included in the common body of norms that are followed in the decisionmaking on international questions. ${ }^{39}$ Respect for human rights by governments in their relationships with their own populations, long considered an internal affair, is an example of an area where norm-setting has been taking place for some time.

Through a strategy of 'moral guidance' the small state may seek to set moral examples. Exemplary moral behaviour enhances, it is thought, the reputation and authority of the small state. The author of the constitution of the Netherlands and leading Dutch statesman of the nineteenth century, J.R. Thorbecke (1798-1872), emphasised the special role a small state could play at the international level by setting moral examples. 'The 
Netherlands does not take part in the envy and enmity of the great states. Therefore, in the long run, it will be less blinded and misled by a particular enmity in advocating the general law and interest... Dutch statecraft, itself free of the lust for power, is the fairest judge over the ambitions of others. ${ }^{\prime 50}$ In the late 1970s Joris Voorhoeve - whose career was to become strangely intertwined with the Dutch involvement in the Yugoslav crisis, first as director of the Clingendael Institute for International Relations and subsequently as Minister of Defence - seemed to believe that there was still an element of truth in such thinking, arguing: 'The freedom of speech which many Small Powers enjoy in international affairs gives them valuable opportunities for good initiatives in multilateral affairs and in mobilising foreign public opinion for humanitarian goals. ${ }^{51}$

A third normative strategy, similar to demonstration politics, is that of 'public criticism'. The immediate goal of public criticism is to inform international public opinion of the fact that an important international principle or norm is being violated and to rally support for a policy of restoring the international moral and legal order. At the same time the criticism serves to underline the moral quality of the small state itself, as Ole Elgström points out: 'Criticism and the formation of opinion are primarily to be understood as instruments for achieving value promotive goals. ${ }^{52}$ Public criticism may also contain a preventive element, particularly where other small states are harmed by the violation of international norms. 'A passive attitude to the fates of others brings disaster to one's own state in the long run. ${ }^{53}$

Strategies of law and order flow from the belief that shared rules and common obligations help to reduce anarchy and increase order in the international system. As E.H. Carr once put it: 'We are exhorted to establish "the rule of law", to maintain "international law and order" or to "defend international law"; and the assumption is made that, by doing so, we shall transfer our differences from the turbulent political atmosphere of self-interest to the purer, serener air of impartial justice.. ${ }^{54}$ The irony in Carr's remark diverts attention from the fact that the search for an international legal order is not solely motivated by naive idealism. There is little doubt that self-interest too motivates small states to promote it, if only because it is a tool that serves to limit the freedom of greater powers to make war. International acceptance of such limitations is promoted by making as many states as possible accountable for their actions in the 
context of internationally agreed law and by the formulation of sanctions as a disincentive for states to deviate from international standards of behaviour. Thus, the Charter of the United Nations tasks the UN General Assembly to encourage 'the progressive development of international law and its codification.' Whatever the precise mixture of altruism and selfinterest as motives for individual states to take this task seriously, the constitution of the Netherlands unequivocally defines international legal codification as one of the central aims of Dutch foreign policy: 'The government promotes the development of the international legal order. ${ }^{55}$

Another way of promoting law and order is the building of international forms of organisation. In an international system that is power-based and adversarial, small states run the risk of being affected by decisions over which they have had no influence. In order to realise 'optimal decisionmaking, that is involvement in the making of decisions whose external effects affect the small state, a small state will seek to promote the creation of formal decision-making structures in which it can voice its opinions and perhaps influence decision-making. ${ }^{56}$ Small states therefore often promote the creation of international organisations and the building of supranational institutions with formalised decision making procedures.

This book begins with a background sketch of the Netherlands and its foreign policy system, presenting the actors involved, their formal and informal roles, and the action channels through which they can influence the decision-making process.

Chapter two analyses the Dutch response to the Yugoslav crisis in its earliest phase from July 1990 until June 1991. It deals with the question of whether the Foreign Ministry received timely warnings and, if so, what response such warnings triggered. It argues that Dutch policy during this crucial phase in the Yugoslav crisis was highly conditioned by the external constraints of regime-membership and marked, moreover, by indifference.

Chapter three deals with the Dutch Presidency of the European Community from July until December $1991 .{ }^{57}$ It sketches the attempt made by the Netherlands to combine the institutional responsibilities of the EC Presidency with the need for an effective response by the European Community towards the Yugoslav crisis. It argues that Dutch policy during this 
period, which gradually developed from 'even-handedness' into 'selectiveness', was influential and successful. Dutch influence to an important degree derived from the prominent position which the Netherlands occupied in the EC. In addition, Dutch institutional interests regarding European integration functioned as a veritable corset on Dutch Yugoslavia policy, keeping any potential tendencies to abandon the European mainstream in check.

Chapter four is concerned with the Dutch response to the peace plans for Bosnia-Herzegovina drawn up by the International Conference on the Former Yugoslavia (ICFY) between late 1992 and early 1994. While the external environment became more competitive, Dutch policy became increasingly driven by domestic moral concerns. It argues that while the Netherlands was influential and, in the short term, successful, Dutch policy ultimately proved counter-productive. It was during this period that the Netherlands entrapped itself ever more deeply in a moral and political sense, paving the way for a subsequent military entrapment.

Chapter five, finally, analyses the development from moral and political entrapment into military entrapment. It argues that the political and moral parameters set by the Ministry of Foreign Affairs, Parliament and public opinion greatly reduced the freedom of the Dutch Ministry of Defence to apply 'objective' military criteria to the Dutch military involvement in the UN intervention in former Yugoslavia. It also argues that the application of such military-operational considerations was further hampered by the desire on the part of the Army leadership to secure a number of bureaucratic-political interests through deployment of the first ready batallion of the airmobile brigade. This combination of domestic factors made it impossible for the Netherlands to adapt its foreign policy behaviour to a more competitive international environment and stave off military entrapment.

NOTES

1 Jan Willem Honig and Norbert Both, Srebrenica. Record of a War Crime (London: Penguin, 1996); Thom Karremans, Srebrenica. Who Cares? (Nieuwegein: Arko, 1998); David Rohde, Srebrenica: Europe's Worst Massacre Since the Second 
World War (London: Pocket Books, 1997); A. van Staden, De fuik van Srebrenica (The fyke of Srebrenica) (Den Haag: Clingendael Institute for International Relations, 1997); Frank Westerman and Bart Rijs, Srebrenica. Het zwartste scenario (Srebrenica. The blackest scenario) (Amsterdam: Atlas, 1997).

2 Omer de Raeymaeker et alia, Small Powers in Alignment (Leuven University Press, 1974), p. 15.

3 For alternative definitions see: Robert Purnell, The Society of States: An Introduction to International Politics (London: Weidenfeld and Nicolson, 1973); Michael Handel, Weak States in the International System (London: Totowa, N.J.: Frank Cass, 1981); Robert L. Rothstein, Alliances and Small Powers (New York and London: Columbia University Press, 1968).

4 Robert O. Keohane, 'Lilliputians' Dilemmas: Small States in International Politics,' International Organization XXIII, No. 2 (1969), p. 296

5 Joris J.C. Voorhoeve, 'Kansen voor Nederland' (Chances for the Netherlands), Internationale Spectator January 1993 - xlvii - No. 1, p. 3.

6 Kenneth Waltz, 'Theory of International Politics', in: Robert O. Keohane ed., Neorealism and its Critics (New York: Columbia University Press, 1986), p. 115.

7 Waltz, Theory of International Politics, in: Keohane, Neorealism, p. 61.

8 Rothstein, Alliances and Small Powers, p. 34.

9 Keohane, 'Realism, Neo-Realism and the Study of World Politics', in: Keohane, ed., Neorealism and its Critics, p. 11. See also: John Stoessinger, 'The Anatomy of the Nation-State and the Nature of Power', in: Richard Little and Michael Smith, eds., Perspectives on World Politics, second edn., (London: Routledge, 1991), p. 4.

10 Handel, Weak States in the International System, p. 257.

11 Mark W. Zacher and Richard A. Matthew, 'Liberal International Theory: Common Threads, Divergent Strands', in: Charles W. Kegley, Jr, ed., Controversies in International Relations Theory. Realism and the Neoliberal Challenge (New York: St. Martin's Press, 1995), pp. 109-110.

12 See: Mark W. Zacher and Richard A. Matthew, 'Liberal International Theory: Common Threads, Divergent Strands', in: Charles W. Kegley, JR. ed., Controversies in International Relations Theory. Realism and the Neoliberal Challenge (New York: St. Martin's Press, 1995), pp. 107-150.

13 Voorhoeve, Peace, Profits and Principles, pp. 11-2, 20.

14 Stephen D. Krasner, 'Structural Causes and Regime Consequence', in: International Organization, 36, 2, Spring 1982, p. 186.

15 The Economist, January 3rd, 1998.

16 Morton Halperin, Bureaucratic Politics \& Foreign Policy (Brookings Institution, Washington D.C., 1974), p. 5. 
17 Jack Snyder, Myths of Empire. Domestic Politics and International Ambition (Ithaca and London: Cornell University Press, 1991), pp. 17-19, 31-55.

18 Graham Allison, Essence of Decision (Boston: Little \& Brown, 1971), p. 173.

19 Judith Goldstein and Robert O. Keohane, Ideas \& Foreign Policy. Beliefs, Institutions and Political Change (Ithaca: Cornell University Press, 1993), pp. 3-30.

20 Ibid., p. 9.

21 Glenn H. Snyder, 'The Security Dilemma in Alliance Politics', World Politics Vol. 36, No. 5, July 1984, p. 467.

22 James Gow, Triumph of the Lack of Will. International Diplomacy and the Yugoslav War (London: Hurst, 1997), pp. 30-31.

23 Gow, Triumph, p. 156

24 Ibid, p. 29

25 Olivier Lepick, 'French Perspectives', in: Alex Danchev and Thomas Halverson, eds., International Perspectives on the Yugoslav Conflict (Oxford/London: MacMillan and St. Antony's College Oxford, 1996), p. 77.

26 David Owen, Balkan Odyssey (London: Gollancz, 1995), p. 171.

27 Lepick, p. 177.

28 Gow, Triumph, pp. 52-53, 60.

29 Viktor Meier, Wie Jugoslawien verspielt wurde (How Yugoslavia was Lost) (München: Beck'sche Reihe, 1996), p. 392.

30 Laura Silber and Allan Little. The Death of Yugoslavia, revised edn. (London: Penguin Books / BBC Books, 1996), pp. 159-162.

31 Meier, Wie Jugoslawien verspielt wurde, pp. 397-398.

32 Susan Woodward, Balkan Tragedy. Chaos and Dissolution after the Cold War (Washington, D.C: Brookings Institution, 1995), pp. 165, 464n.76.

33 Silber and Little, The Death of Yugoslavia, p. 260.

34 Paul Scheffer, Een tevreden natie. Nederland en het wederkerend geloof in de Europese status quo (A satisfied nation. The Netherlands and the recurring belief in the European status quo) (Amsterdam: Bert Bakker, 1988), p. 26.

35 Scheffer, Een tevreden natie, p. 28.

36 Ibid., p. 258.

37 William M. Habeeb, Power and Tactics in International Negotiation. How Weak Nations Bargain with Strong Nations (Baltimore: Johns Hopkins University Press, 1988). See also: Alfred van Staden, 'Small State Strategies in Alliances. The Case of the Netherlands', Cooperation and Conflict 1995, vol. 30 (1), p. 37.

38 Handel, Weak States, p. 120.

39 Ibid.,p. 103.

40 See: Handel, p. 124; Robert O. Keohane, 'The Big Influence of Small Allies', in: Foreign Policy, No.2, 1971, pp. 164-167; John Odell, 'Latin American Trade 
Negotations with the United States', quoted in: Habeeb, Power and Tactics, p. 7. For a practical example, see: Yihtzak Rabin, The Rabin Memoirs, 2nd. edn. (Bnei Brak, Israel: Steimatzky, 1994), p. 181; Rothstein, Alliances and Small Powers, p. 49.

41 Ulf Lindel and Stefan Persson, 'The Paradox of Weak State Power', in: Cooperation and Conflict XXI, 1986, p. 89.

42 Cf. Alfred van Staden, Een trouwe bondgenoot: Nederland en het Atlantisch Bondgenootschap (1960-1971) (A faithful ally: The Netherlands and the Atlantic Alliance, 1960-1971) (Baarn: In den Toren, 1974).

43 Ph. Everts and G. Walraven, The Politics of Persuasion: Implementation of Foreign Policy by the Netherlands (Aldershot: Gower, 1989), pp. 323-341.

44 Axelrod and Keohane, in: Kenneth A. Oye, ed., Cooperation under Anarchy (Princeton N.J.: Princeton University Press, 1986), p. 240.

45 Keohane, 'Big Influence', p. 180; Joris J.C. Voorhoeve, Peace, Profits and Principles. A Study of Dutch Foreign Policy (Den Haag: Martinus Nijhoff, 1979), p. 319.

46 Voorhoeve, Peace, Profits and Principles, p. 319.

47 Scheffer, p. 42.

48 Cf. Von Dosenrode-Lynge, pp. 68-9.

49 Tove Lise Schou, Norge og EF, quoted in: Von Dosenrode, p. 71.

50 Quoted in: Voorhoeve, Peace, Profits and Principles, p. 51.

51 Ibid., p. 317.

52 Ole Elgström, 'Active Foreign Policy as a Preventive Strategy Against Dependence', Cooperation and Conflict, XVI, 1981, p. 244.

53 Elgström, 'Active Foreign Policy', p. 245.

54 E.H. Carr, The Twenty Years' Crisis 1919-1939 (London: MacMillan, 1995), p. 159.

55 Article 90 of the constitution of the Kingdom of the Netherlands.

56 Mr.B.V.A. Röling, Volkenrecht en vrede (Humanitarian law and peace), 3r d edn.(Deventer: Kluwer, 1985) p. 33.

57 The Presidency of the then European Community - European Union since late 1993 - rotates between the member states. The current, previous and incoming presidencies together form the 'Troika'. Italy held the Presidency during the second half of 1990, Luxembourg during the first half of 1991 and Portugal during the first half of 1992. 


\section{The Netherlands and its Foreign Policy System}

Located in Northwestern Europe, the Netherlands has a population of around 16 million people, squeezed into a territory of only 41,526 square kilometres. The country's origins as a political entity can be found in the sixteenth century. In 1568 a revolt led by William of Orange started in the 'Low Countries' against Habsburg Spain, which, after an eighty year war resulted in the recognition of the independence of the Northern part as the Republic of the Seven United Netherlands at the Treaty of Westphalia. The Southern part (presentday Belgium) remained under Habsburg rule. These seven provinces, with Holland and Zeeland as the predominant powers, had by then become a formidable maritime power with strongholds in, for instance, modern-day Indonesia, South India, South Malaysia, Sri Lanka, South Africa, Brazil, New York as well as dominating trade on the Baltic sea. ${ }^{1}$ The seventeenth century is known as the 'golden age' of Dutch history, famous for its cultural achievements and economic prosperity. ${ }^{2}$ The eighteenth century was a period of stagnation for the Netherlands, as well as being under French influence from 1795 to 1813. Meanwhile, the colonial empire was taken over by the British and only partly restored after 1813. After Napoleon was defeated, the House of Orange was restored and the Northern and Southern Netherlands (Belgium) were united in the Kingdom of the Netherlands. The Belgian revolution of 1830 brought a quick end to this new state and resulted in the formation of the Kingdom of Belgium in 1831. During the First World War, the Netherlands' neutral status was respected. At the beginning of the Second World War, the Netherlands again declared itself neutral, but this time it was not respected. In May 1940, the country was overrun by 
Nazi Germany in five days. The defeat was followed by five years of occupation that saw most of the Dutch Jewish population exterminated in concentration camps.

The Nazi occupation together with the extermination of the Jewish population still constitutes one of the two most influential experiences for contemporary Dutch society. The other one was the 'loss' of Indonesia. Much of post-war Dutch foreign policy can be understood as a quest for compensation for the loss of status as a maritime and colonial power. ${ }^{3}$ The decolonisation of Indonesia was contested by the so-called police actions of the Dutch army during the second half of the 1940s, which left over 6,100 Dutch soldiers dead, a higher proportion of the population (some 9 million at the time) than American casualties in Vietnam. Compensation for this ultimate loss of status as a maritime power was sought in a material sense, for instance through its membership of NATO and through its maintaining a relatively large navy. Compensation was also sought in a psychological sense, though not necessarily by the same elements in Dutch society, through an emphasis on morality and international law, as well as a relatively large development aid budget as instruments of foreign policy. Thus, Foreign Minister Max van der Stoel told Parliament in 1977 'that the Netherlands must sometimes regard as one of its tasks the airing of a principled voice, even if this harms the interest of the [Netherlands as a] merchant.' ${ }^{4}$ According to Paul Scheffer, a columnist for the NRC Handelsblad, the Dutch emphasis on morality in foreign policy sometimes even turned into a 'kind of moral imperialism.' He states: 'Although an emphasis on moral codification is a rational attitude for a small country, it has degenerated more than once into a misplaced sense of superiority and a moralisation of essentially pragmatic conflicts between nations. ${ }^{5}$

The search for compensation in terms of status was hampered by an increasingly negative self-image among the first post-war generation in the 1960s and 1970s. During the first two decades after the Second World War, the fundamental consensus about good and bad had been a binding element in Dutch society and Dutch foreign policy. This dichotomy was easily applied to various developments in the real world. Nazi Germany represented evil during the war, but after the war the atheistic, totalitarian, and Communist Soviet Union, came to epitomise the real evil empire. During the Cold War, the USA and its allies, on the other hand, represented the forces of good. With this world view came the principled belief 
that Dutch 'foreign policy behaviour needs to be (and, in the case of the Netherlands, is) founded on an active choice for good against evil'. 6

During the 1970s, the good-bad dichotomy was modified to include the belief that the Netherlands did not by definition represent the forces of good. Many people who had been born after the Second World War found it difficult to reconcile the self-image of moral virtue prevalent in Dutch society with their knowledge of recent Dutch history. A comparatively large number of Dutch Jews had been put to death in the Nazi concentration camps. Seventy-five per cent of Dutch Jews were killed, in comparison with forty per cent of Norwegian and Belgian Jews, twentyfive per cent of French Jews, while virtually all of the Danish Jews escaped unscathed. ${ }^{7}$ This implied that Dutch society carried a greater degree of moral 'guilt' than parents and grandparents usually admitted. Another burning question was how one could reconcile the supposed Dutch moral virtue with the military campaigns in Indonesia, which in retrospect so obviously violated the principles of self-determination and human rights. Finally, Watergate, US policy in Latin America, and the war in Vietnam destroyed much of the young's faith in the USA and the West as a whole. Instead, in the battle between good and evil, it was the newly independent countries or independence movements in the Third World who were fighting the good fight. During the 1970s, the 'public aversion to NATO was primarily related to the fact that NATO was seen by many as a suppressive institution in the Third World.'

While this essentially negative self-image became a powerful social force from the mid-1960s onwards, it was the Labour/Christian Democrat Cabinet (installed in 1973), which translated it into formal Dutch foreign policy. The 'mundialist' foreign policy of this coalition was rooted in the Labour Party's 1972 election manifesto 'Keerpunt', which stated: 'Solidarity with oppressed groups, wherever they are found in the world, shall replace allied obedience.' Indeed, the Dutch Labour/Christian Democrat coalition showed courage, as one commentator put it, 'by linking up, as a Western government, with the attempt of others to push back Western dominance. ${ }^{10}$

According to some, it took the Netherlands until the 1980s to come to terms with its position in the international system. In retrospect, the 1990s may be said to have witnessed the completion of this process of 
'normalisation'. Although 'Srebrenica' constituted a blow to the Dutch self-image, it was also a sobering experience and was one of the factors that served to further 'pragmatise' Dutch foreign policy. The Dutch armed forces, in turn, played a constructive role as part of the Rapid Reaction Force in Bosnia in 1995 in the NATO air operations over Bosnia during that same period, and as one of the three largest contributors to the NATO air operations over Kosovo. ${ }^{11}$ Within the EU, the Netherlands became a successful bilateral deal maker. In addition, the economic austerity measures (wage moderation and restraint in public spending) taken by successive governments since the early 1980s began to pay off in the second half of the 1990s. The Dutch 'polder model' gained international fame as the country managed to combine strong economic growth and social stability. ${ }^{12}$

\section{The Foreign Policy System: General Characteristics}

The Netherlands is a constitutional, parliamentary monarchy. The constitution, which dates back to 1814 , has been amended several times, mainly to increase the powers and responsibilities of the Cabinet and Parliament. ${ }^{13}$ Given that elections are held on the basis of proportional representation, Cabinets are usually comprised of coalitions of two or more political parties. Before they take up office, the coalition partners must draw up a detailed governing agreement, which serves as the basis of the coalition's policy during its four-year term in office. Between 1990 and 1994, the CDA (Christian Democrats) and the PvdA (Labour) constituted the ruling coalition. In 1994, the so-called purple coalition, consisting of the PvdA, the VVD (Conservative Liberals), and D66 (Liberals) was voted into power.

The Cabinet is accountable to Parliament, or the States General, which in turn consists of a Lower or Second Chamber and an Upper or First Chamber. The Second Chamber of Parliament is the more important: it consists of 150 parliamentarians who are nominated by political parties and elected on the basis of proportional representation by the entire electorate. The First Chamber constitutes a veritable Chambre de reflection, checking whether procedures have been followed and whether laws are clear and not open to conflicting interpretations. Its role in foreign policy is limited. Parliamentarians who become Cabinet Ministers must give up their parliamentary seat. 
The most important means by which Parliament can influence foreign policy is the 'motion'. Parliament may pass motions to reflect the specific requests or opinions of a parliamentary majority. However, as Philippe Everts points out, 'the government is not obliged to carry them out' and Ministers have 'repeatedly refused to act according to the expressed will of the Second Chamber.' ${ }^{14}$ Through a motion of 'no confidence', Parliament may ultimately force a particular Minister or the entire Cabinet to resign. This means that a Foreign Minister and Defence Minister will most likely try to find as broad a base of support as possible in Parliament and within their own party for their policies.

While formally possessing only limited powers, in practice the Second Chamber's voice in defence matters was greatly enhanced by one unique means of parliamentary control over Dutch foreign and security policy. The origin of this means occurred in 1979, when the Dutch government irritated the Second Chamber by announcing the decision to commit soldiers to the UN operation in South Lebanon (UNIFIL) without prior consultation. ${ }^{15}$ The Second Chamber responded by passing two motions, which stated that its consent would depend on the fulfilment of two conditions. In the first motion, Parliament demanded that conscripts could not be deployed outside of the NATO area against their will. In the second motion, Parliament requested that 'the Government, in the future not make decisions regarding the participation of the Netherlands in a UNpeacekeeping force until it had consulted with the [Second] Chamber. ${ }^{16}$ In practice, this meant that although the Second Chamber did not possess the power of co-decision making, the government became obliged to consult it before an actual military deployment was begun. ${ }^{17}$ Although the motion was intended to serve as a brake on the enthusiasm of governments to send troops abroad, during the early 1990s, its effect was the opposite, because it enabled the Second Chamber to also function as a spur to increased troop deployments. In the 1990s, the Second Chamber wanted to further tighten its grip on defence policy through a constitutional amendment giving it the right to co-decide on troop contributions. As a compromise, Parliament approved the Toetsingskader, a set of elements for decision making drawn up by the Minister of Foreign Affairs and the Minister of Defence in June 1995, i.e., one month before the fall of Srebrenica.

With regard to foreign policy, the Second Chamber conducts most of its parliamentary tasks through the permanent committees for Foreign 
Affairs and Defence, in which the parties' foreign and defence affairs specialists have a seat. The larger political parties will each appoint an individual to the two permanent committees. Smaller parties, however, have to improvise. While the two committees may and do meet separately with the responsible Cabinet Minister, they also frequently meet jointly with both the Minister of Defence and the Minister of Foreign Affairs aside from the regular briefings by officials. Debates of a sensitive nature are usually conducted by the parliamentary party leaders. Usually it is only the annual budget debates that attract a full Second Chamber.

Richard Eichenberg has pointed to the sensitivity to public opinion of successive Dutch governments. Commenting on Dutch attitudes on nuclear weapons in the early 1980s, he concludes: 'What seems to be unique about the Dutch case is not the level of public scepticism of security policies but the comparatively strong impact that opinions have had on Dutch governments. ${ }^{38}$ In fact, of all the domestic actors who play a formal role in the making of Dutch Foreign policy, Parliament is the most obviously receptive to public opinion. As Jan Hoekema, a Member of Parliament (MP) and former senior Foreign Ministry official, puts it, it is incredible how we are influenced by what is written in (Dutch daily newspapers) de Volkskrant and the NRC-Handelsblad.' ${ }^{19}$ Well-connected pressure groups, for their part, are able to mobilise like-minded MPs with proposals for posing official parliamentary questions to the government.

\section{The Cabinet}

In the Cabinet, the role of the Prime Minister is that of a broker and coordinator, given that the Cabinet is a multi-party coalition and all the important decisions are the 'collective' responsibility of the entire Cabinet. Between 1990 and 1994, Christian Democrat politician, Ruud Lubbers, was the Prime Minister. His successor was Wim Kok, a former labour union leader, who became the leader of the Social Democrat PvdA and had been part of the Cabinet under Lubbers as Finance Minister. Clearly, in the Dutch political system the position of the Prime Minister, particularly with regard to foreign policy, has not been as strong as in many other democratic systems. His constitutional role is that of primus inter pares. In a coalition government, inevitably some Ministers do not belong to the Prime Minister's own party and are not always willing to agree with him. The Ministers can be quite assertive in defending the 
interests of their own Ministry or party, given that the Prime Minister cannot just dismiss them at his whim. ${ }^{20}$ The formal weakness of the Prime Minister's role is balanced by the shared desire for continued governance and the consequent need for a broker. The degree to which the Prime Minister can use his high profile to assemble direct public support from the electorate may also be important - this is the so-called Prime Minister's bonus. Finally, the European dimension has considerably enhanced the role of the Prime Minister in foreign policy through the European Council of Heads of State and Heads of Government.

Despite the growing importance of the Prime Minister, the key role in Dutch foreign policy is still reserved for the Minister of Foreign Affairs, who heads the bureaucracy that largely determines the agenda of Dutch foreign policy in most areas, including European cooperation. With this major asset, and because he has the formal responsibility of presenting proposals to the Cabinet regarding foreign policy, the Foreign Minister is still 'unquestionably the dominant actor regarding foreign policy in the Netherlands. ${ }^{21}$ The Foreign Minister's position can be particularly strong if he is a member or even leader of a different party than that of the Prime Minister, if he commands the loyalty of his civil servants, and if he exploits his formal powers to the fullest. Thus, in practice, Cabinet decisions regarding foreign policy are usually endorsements of policy proposals by the Foreign Minister. When other Ministries are involved, a prior agreement between the Minister of Foreign Affairs and, say, the Minister of Defence will usually be sufficient to secure an endorsement by the Cabinet. ${ }^{22}$

The position of the Dutch Foreign Minister is further strengthened by the fact that in European matters, the Prime Minister operates on the basis of a Cabinet mandate. It is the Foreign Minister, in turn, who plays the key role in the formulation of this mandate. Usually, the Cabinet offers the Foreign Minister great freedoms in this area. Thus, the Foreign Minister 'has remained pre-eminent in foreign policy'.23 Having said this, there is no doubt that the complex relationship between the Prime Minister and the Foreign Minister with regard to European cooperation can and does cause tensions. There are regular calls for the Prime Minister to be given a greater role in formulating foreign policy. ${ }^{24}$ 
The first three years of Dutch Yugoslavia policy formulation since 1990 were carried out under the responsibility of Hans van den Broek, the long-serving Foreign Minister. Van den Broek was a member of the CDA and was known as an 'Atlanticist'. Described as a 'statesman' by former US Secretary of State James Baker, Van den Broek was famous for his loyalty to NATO and the United States until well after the fall of the Berlin wall. ${ }^{25}$ In Europe, Van den Broek strongly favoured integration on a supranational basis. He was said to hold a tight reign over the Foreign Ministry, to have a preference for 'silent diplomacy', and to possess a detailed knowledge of the 'dossiers' he controlled. His relationship with both Lubbers and Defence Minister Relus ter Beek was uneasy, as was his relationship with a number of foreign colleagues including, and in particular, German Foreign Minister Hans-Dietrich Genscher. Van den Broek's successor, fellow CDA politician Pieter Kooijmans, re-entered Dutch politics following a long absence during which he served as professor of international law at the University of Leiden. A domineering but likeable figure, Kooijmans had a reputation for moral virtue and showed himself to be a fighter for human rights. In addition, the polarising institutional questions regarding the European Union had been pushed into the background following the conclusion of the Treaty on European Union (TEU) in Maastricht, the Netherlands, in 1992.

Finally, Hans van Mierlo, the leader of D66, sailed into the maelstrom of Dutch Yugoslavia policy in 1994, directly after completing long drawn out negotiations for a coalition agreement. Known as an articulate speaker, an exhausted Van Mierlo needed some time to grasp all the details of the current issues in international politics. Van Mierlo's main innovation was to weaken the Atlantic orientation of the Netherlands somewhat in favour of a more European orientation. In the traditional battle with the Minister for Development Cooperation (development aid) over control of the Foreign Ministry, Van Mierlo had a difficult time holding his own. ${ }^{26}$ Van Mierlo complained about the heavy workload, and in 1998 he proposed the introduction of a second State-Secretary.

The Minister of Defence was long recognised as the junior partner in the relationship with the Foreign Minister. For much of the post-war era he was seen as the keeper of the 'iron shop'. Indeed, within the Cabinet, the Defence Minister had for a long time been operating as if he was simply the guardian of the defence budget, meaning he assured that the 
equipment plans of the three armed services were not compromised. In this function, the Defence Minister usually had the support of the Foreign Minister, given their shared interest in maintaining a certain level of military power. In his budget battles with other Ministers, the Defence Minister's position was strengthened by his ability to claim that his budget was tied to NATO 'obligations'. ${ }^{27}$

Three elements partly compensate for the intrinsic weakness of the Minister of Defence's position vis-à-vis the Foreign Minister. First, since the 1970s it has been increasingly difficult to distinguish between the political and military aspects of security, such as the proliferation of atomic, biological and chemical (ABC) weapons. ${ }^{28}$ This development was reflected in the organisational reforms at the Ministry of Defence, where the creation of a Department for General Policy affairs (Directie Algemene Beleidszaken; DAB) increased the Defence Ministry's level of political clout. Second is the fact that he does indeed head the 'iron shop'. Whereas the Foreign Minister may decide what is desirable in terms of military commitments, it is the Defence Minister who determines whether what is desirable is also physically viable. Thirdly, international peacekeeping operations have proliferated and become an increasingly important component of Dutch foreign policy, thereby increasing the Defence Minister's power.

The end of the Cold War triggered an important reform in the Defence Ministry's structure, which in the long term will probably also enhance the position of the Defence Minister. From 1990 to 1994, PvdA Minister of Defence Relus ter Beek initiated and oversaw the implementation of the abolition of conscription and the creation of an all-volunteer army. Given the decreased likelihood of large-scale conflict on the European continent, the Cold-War dividend was cashed in by reducing the size of the armed forces.

\section{The Ministry of Foreign Affairs}

The political leadership of the Ministry of Foreign Affairs consists of two Ministers and a State-Secretary (junior Minister). The 'ship's captain', as Prime Minister Wim Kok once put it, is the Minister of Foreign Affairs. ${ }^{29}$ The other Minister is responsible for development cooperation (development aid), a post that was introduced in 1965. Though without a 
Ministry of his own, the Minister for Development Cooperation annually spends 0.8 per cent of Dutch GDP. According to Voorhoeve, the 'twoheaded leadership [of the Foreign Ministry by the Minister for Foreign Affairs and the Minister for Development Cooperation] has usually (but not always) worked smoothly' ${ }^{30}$ In fact, in the 1990s the inevitable demarcation disputes increased as the zealous and skilled Minister for Development Cooperation, PvdA politician Jan Pronk, was widely perceived to be successfully expanding his control over the Ministry at the expense of successive Ministers of Foreign Affairs. The third political figure is the State-Secretary, a junior Minister with no Cabinet rank but with the formal right to attend Cabinet meetings. The State-Secretary is usually charged with Dutch policy regarding 'European integration'.

The Dutch civil service has traditionally known few appointments that are tied to party-political affiliation. Civil servants are expected to be loyal to the Minister regardless of their political views. In the Foreign Ministry, as in all Ministries, the senior civil servant is the Secretary-General. Usually referred to as ' $S$ ', the Secretary-General's main responsibility is to manage the civil apparatus. Together with his deputy, the SecretaryGeneral coordinates the flow of information from civil servants to the political leadership. As Frank Majoor, a former director of the Security Policy Affairs Department, put it, 'the idea is that the Secretary-General is the guardian of the system. ${ }^{31}$ Interestingly, Majoor was appointed Secretary-General in 2000.

In 1995, the government produced a 'Reorientation'-paper, which was meant as a response to the end of the bipolar international system that had accompanied the Cold War. Since the Reorientation, the formal flow of information to the political leadership has emanated from four Directorates-General, where there used to be only three. Until 1995, the most important Directorate-General in the case of the Yugoslav crisis was the Directorate-General for Political Affairs (DGPZ), headed by the DirectorGeneral for Political Affairs and his deputy. The other two were the Directorate-General for European Affairs (DGES) and the Directorate-General for International Cooperation (DGIS). Since the Reorientation, the regional departments of the DGPZ and the DGIS have merged to become the backbone of the new Directorate-General for Regional and Country Policy affairs (DGRB), led by a Director-General and a deputy. The regional departments are supposed to serve all four Director-Generals 
and all three political leaders and thus play a coordinating role within the Ministry.

The Director-General for Political Affairs and his deputy focus on the classic 'high-politics' issues, such as the Yugoslav crisis, the Middle East and the central African conflicts, and coordinate the Dutch input into the EU's Common Foreign and Security Policy. They are supposed to coordinate the political activities of the other Directorates-General and maintain the general policy line of the Ministry as a whole. ${ }^{32}$ Those sections in the Directorate-General for Regional and Country Policy affairs whose work is highly political will in practice receive their instructions from the Director-General for Political Affairs.

Before the Reorientation, the most influential department under the direct authority of the Director-General for Political Affairs was the Atlantic Security and Cooperation Affairs Department (DAV), renamed the Security Policy Affairs Department in 1995, and subsequently enlarged from approximately 17 to some 27 officials. DAV/DVB is responsible for formulating policy regarding NATO, the Western European Union (WEU), and the Organisation on Security and Cooperation in Europe (OSCE) as well as the various treaties on arms control. Throughout the Cold War, DAV/DVB in practice also managed bilateral relations with the United States, the most important NATO ally. Finally, it is DAV/DVB which maintains relations with the Ministry of Defence.

The European Affairs Department was also heavily involved in the formulation of Dutch Yugoslavia policy, first as part of the Directorate-General for Political Affairs, and since 1995, as part of the Directorate-General for Regional Policy. At the outbreak of the Yugoslav crisis in 1990-1991 the Eastern Europe Division, responsible for bilateral relations with all of the Warsaw Pact members, as well as Yugoslavia and Albania, consisted of three officials - increased to four during the Dutch EC Presidency. Subsequently this was split into an Eastern Europe Division and a Central Europe Division, the latter of which eventually expanded to some ten people, approximately six of whom were concerned with the region of the former Yugoslavia and Albania (Western Balkans). This informal subdivision dealing with the Western Balkans was headed by a 'co-ordinator'. In 1999, a separate Balkans task force was created to coordinate the Dutch input into the recently created 'Stability Pact for Southeastern Europe'. 
The co-ordinator for the affairs of the former Yugoslavia since 1992 has chaired a weekly meeting, which has brought together officials from as many as eight different departments as well as, at times, an official from the Ministry of Defence, in order to discuss current developments and identify options.

Another department that contributed to the making of Dutch Yugoslavia policy was the UN Affairs Department, which controlled communications with the Permanent Mission in New York. The Security Council played a crucial role in international Yugoslavia diplomacy, particularly during the period of the UN's humanitarian intervention in former Yugoslavia between 1992 and 1995, which meant that within the Ministry, the UN Affairs Department was relatively influential.

Hanno Würzner, a former senior desk officer in the UN Affairs Department, gave the following description of the roles played by the different departments: 'For the people in the Atlantic Affairs Department, the main concern was "NATO credibility". This translated into strong support for the use of NATO air power. We from the UN Affairs Department were much more oriented towards the humanitarian side of the UN peacekeeping operation itself. The people in the European Affairs Department studied the nature of the successive peace plans on the table and did not shrink back from taking a moral stance. ${ }^{33}$

There were also other important Foreign Ministry actors, who were active during the period under discussion, such as the Embassy in Belgrade, the Permanent Mission at NATO in Brussels and the Permanent Mission at the United Nations in New York. During the early phases of the crisis, the Dutch Ambassador to France, Henry Wijnaendts, also played an important individual role, first as a special representative of the European Community and, subsequently, as deputy chairman to the EC Peace Conference, chaired by former British Foreign Secretary, Peter Lord Carrington in 1991 and 1992. ${ }^{34}$

\section{The Ministry of Defence}

The other politician in the Ministry of Defence besides the Minister is the State-Secretary. Whereas the Defence Minister focuses on general defence policy and spends much of his time with his senior civil and military 
advisers, in Parliament, with the Cabinet or abroad for meetings with fellow NATO and WEU defence Ministers. The State-Secretary's traditional tasks involve operational responsibility for policies regarding equipment and procurement, as well as with manpower planning if a Minister so desires.

The Defence Ministry's senior nonpolitical figure is the Secretary-General. He is always a civilian in order to emphasise the primacy of the civil over the military. The Secretary-General is mainly responsible for the day-to-day management. The Secretary-General's easy access to the Minister sometimes causes irritation among senior military. ${ }^{35}$

Two other groups of (mainly) civil servants in the Defence Ministry play an important role in the formulation and presentation of defence policy and in the management of the Ministry's external affairs. These are the officials in the Department of General Policy Affairs (DAB) and the senior spokespersons in the department of information, which always has a representative in the company of the Minister.

The DAB officials, in particular, have a reputation for political shrewdness. DAB officials prepare the Minister's statements to Parliament and draft his speeches. A former head of the department once articulated the extent of the DAB's loyalty to the Defence Minister as follows: 'We do everything for the Minister. If he wants a speech on rhyme, he will get it on rhyme. ${ }^{36}$ In a remark which revealed the influence that the DAB officials (are perceived to) have, former Commander of Land Forces Lt. General Hans Couzy once lamented that while a Commander of Land Forces 'does not belong to the Minister's most intimate', the DAB officials are the Minister's 'trustees.' ${ }^{37}$

The highest senior military official is the chief of the Defence Staff. He is the only four-star officer in the Dutch armed forces and the Minister's top military adviser. While formally ranked below the Secretary-General, the chief of the Defence Staff, in practice, is treated as the Secretary-General's military counterpart. Whereas communication between the chief of the Defence Staff and the Minister formally runs through the Secretary-General, a trusted chief of the Defence Staff will be able to develop his own line of communication to the Minister. The chief of the Defence Staff plays a crucial role particularly when Dutch troops are involved in opera- 
tions abroad. Meanwhile, the deputy chief of the Defence Staff assists his superior and becomes the acting chief of the Defence Staff in the latter's absence. Here too, informal influence may be greater than formal influence. The chief of the Defence Staff also functions as a primus inter pares with regard to the commanders of the three armed services: the Royal Army, Royal Navy, and Royal Air Force, all of whom are entitled, however, to approach the Minister directly.

\section{Cooperation between the Foreign and Defence Ministries}

During the period under discussion, apart from regular ad hoc visits and telephone calls between the two Ministries, as well as - sometimes joint telegram traffic, there was no tightly structured framework to ensure the interlocking of political and military views in the policy formulation process. Formal communications between the two Ministries included a daily Defence Ministry briefing on the situation of Dutch troops abroad, attended by an official from the Foreign Ministry's Department for Atlantic Security and Cooperation Affairs (DAV). Officials from the Defence Ministry's DAB were invited to participate in the weekly Foreign Ministry meeting chaired by the Yugoslavia-co-ordinator. Given that these meetings were attended by some 8 different Foreign Ministry departments and sections (dealing with for instance: humanitarian aid, information, European integration and human rights), they were not effective in securing an open and clear communication between the two Ministries.

\section{The Informal Foreign Policy Machinery}

The academic community maintains relatively close relations with politicians, with whom they discuss current issues on the basis of membership of the same political party, or simply on the basis of common interest. Relations between the academic community and the civil service are much less warm. The Dutch Foreign and Defence Ministries still are remarkably closed bureaucracies with relatively little interest in the opinions of the academic community other than those produced in the most influential daily newspapers and television programmes. Nevertheless, given that a select group of academics have relatively easy access to the media they can be influential in an indirect way. 
A number of national newspapers are widely read, while politicians and senior officials (much more so than junior officials) also keep an eye on what is written in such international media as the International Herald Tribune, the Economist, and the New York Review of Books. Domestic and foreign television programmes like NOVA, Netwerk, BBC Newsnight, and $C N N$ are watched with varying degrees of intensity. While it is difficult to estimate the influence of the media on the Dutch foreign policy process, it is clear that the domestic press in particular often succeeds in influencing foreign policy, primarily by provoking parliamentarians to react.

Parliament will not support particular foreign policies unless they are perceived to be backed by a majority of the Dutch electorate. This is particularly true with regard to the question of whether to support the deployment of Dutch troops abroad. Parliamentarians are quite susceptible to public opinion as expressed in polls and through the media. One organisation that regularly monitors the Dutch public's attitudes regarding the involvement of Dutch forces in military operations abroad is the Stichting Maatschappij en Krijgsmacht (Foundation for Society and Armed Forces), which has its own magazine and internet site. ${ }^{38}$

\section{The European Dimension}

Dutch foreign policy is formulated within the framework of a number of international organisations or, more generally, regimes. The regime that intervenes more directly than any other into the Dutch formulating process is that of the European Union. The interlocking of national and European policy formulation takes place in the framework of the Common Foreign and Security Policy, which succeeded European Political Cooperation (EPC) as the EU's 'collective enterprise through which national actors conduct partly common, and partly separate, international actions. 39

Until November 1993, the EC member states were exchanging information, consulting one another, taking joint action in the field of foreign policy through European Political Cooperation. Through EPC, the EC member states aimed to maximise their influence in international affairs by developing common approaches to foreign policy issues. While EPC had gradually been developing ever since the 1950s, it was not until 1987 that the process was formalised as part of the Single European Act (SEA) 
and was provided with a permanent Secretariat to support the country holding the Presidency of the Council of Ministers.

European Political Cooperation was organised on a strictly intergovernmental basis and served as a platform for co-ordinating national foreign policies. Decision making took place on the basis of unanimity. The shared desire for consultations and information exchanges did not mean 'that essential interests would automatically be interpreted in a uniform manner'. ${ }^{49}$ Each member state also used EPC as a platform for maximising national influence and defending national interests. Nevertheless, most member states tried to make EPC work. Until the eruption of the Yugoslav crisis, EPC was regarded as 'one of the few bright spots' of European integration. ${ }^{41}$

The Treaty on European Union (TEU), concluded in Maastricht in the Netherlands in 1991, created a European Union of which a Common Foreign and Security Policy constituted one of the three main pillars. CFSP has retained the intergovernmental basis of EPC, with unanimity as the most important form of decision making. Some areas of decision making, such as disarmament and arms control, were deemed of sufficient 'common' interest to allow for Qualified Majority Voting (QMV). In addition, the Council of Ministers can, by consensus, designate particular matters to be decided by QMV. The treaty also mentions the possibility of eventually framing a common defence policy/organisation. Finally, the Treaty stipulates that the member states will 'to the extent possible, avoid preventing a unanimous decision where a qualified majority exists in favour of that decision.' ${ }^{42}$ Nevertheless, the fact that the most important decisions are still made on the basis of unanimity, indicates that member states are reluctant to risk the possibility of being outvoted on issues they consider to be of vital national interest. The Treaty of Amsterdam, agreed in 1997, foresees common strategies in which decision making is taken on the basis of QMV. By 2000, two common strategies had been formulated, one of which dealt with Russia. The other related to Ukraine.

The 'European Council' of Heads of State and Heads of Government of the EU member states, which commenced as a regular informal gathering, was formalised with the SEA and the TEU and endorsed in Edinburgh in 1992. Given that the European Council 'ensures coordination between the various Councils and the many policy areas now subject to 
European integration', the visibility of the heads of government and state in matters of foreign policy has increased. This development is reinforced by the fact that the European Council, unlike the regular Council of Ministers, can meet 'outside the mainstream institutional framework', and can cut through 'all the procedural formality, which that involves.' ${ }^{43}$ Finally, while the Foreign Ministers have been more successful than most Ministers at retaining their autonomy in their area of expertise, 'the original central coordinating and strategic role' of the Foreign Ministers' General Affairs Council (GAC) 'has been weakened by the existence of the European Council.' ${ }^{44}$ The enhanced visibility of the Dutch Prime Minister in European affairs was recognised in the Reorientation paper of 1995, which notes a greater role for the Prime Minister in the 'presentation' of foreign policy.

Despite the growing importance of the European Council, in most EU countries the Foreign Minister remains the key player for several reasons. The preparations for the European Council are carried out by the various Councils of Ministers, the most important of which is the Foreign Ministers' GAC. Secondly, decisions by the European Council only obtain legal force once they have been adopted by the relevant Council of Ministers according to normal legal procedures. Fiona Hayes-Renshaw and Helen Wallace point out that, 'without the preparatory and executive functions of the Council [of Ministers], the European Council would be unable to function. ${ }^{45}$ In addition, unlike the other Ministers, the Foreign Ministers' competence encompasses both Community and CFSP affairs. Finally and most importantly, the direct influence of the Foreign Ministers is ensured by their physical presence at the European Council as the only other political figures besides the heads of government or state.

In fact, EPC/CFSP has increased, rather than decreased, the domestic powers of most European Foreign Ministers. Whereas the Prime Minister may be gaining influence through the European Council, at the expense of the Foreign Minister, EPC/CFSP has enabled Foreign Ministers to reaffirm their coordinating role vis-à-vis other national Ministers. EPC/CFSP has 'demarcated an area of European cooperation that was unarguably the proper reserve of the Foreign Ministries, and allowed those Ministries to re-establish their traditional positions of primacy within their national civil services. ${ }^{36}$ 
The main advisory body to the General Affairs Council is the Political Committee (CoPo), consisting of the Political Directors from the member states' Foreign Ministries. The political directors prepare the work of the Ministers on issues of foreign policy. The CoPo also oversees the work of specialised working groups. Finally, the CoPo prepares the discussions and conclusions of the European Council of Heads of State and Heads of Government regarding issues of foreign policy. It may do so at its own initiative. The influence of the CoPo in meetings of the European Council is significant, given the presence of its immediate masters, the Foreign Ministers, at the meeting itself. The CoPo normally agrees on CFSP agenda items (which can subsequently be modified by the Foreign Ministers) two days before the European Council. It meets on the first day of the summit to discuss and draft the CFSP declarations to be included in the final conclusions. The individual members of the CoPo are senior figures in their national delegations, and trusted advisors to their Foreign and prime Ministers. ${ }^{37}$

Until the TEU concluded at Maastricht, the CoPo's area of competence was kept very much apart from that of its counterpart involved in Community affairs, the Committee of Permanent Representatives (COREPER). The Political Directors met regularly in the country holding the EU Presidency. From 1993 onwards, several operational procedures were introduced to enhance the unity of purpose between the Political Committee and COREPER in preparing for General Affairs Councils and European Councils. ${ }^{48}$

Much of the groundwork in the attempts by the European Union to coordinate national policies and formulate common policies, is done in specialised working groups. In the context of the Yugoslav crisis, policy coordination initially took place in the Eastern Europe Working Group and subsequently in the Committee on former Yugoslavia (COYUG), later renamed COWEB (Committee on the Western Balkans).

The Ambassadors of the EU member states in any given post, apart from undertaking their own bilateral activities, will try to reconcile their positions as much as possible at regular meetings and thereby present common positions in their host country. In addition, the Ambassadors may be called upon to assist the CoPo to prepare draft declarations for the General Affairs Council and European Council. In the case of the 
Netherlands, a bilateral treaty between the Grand Duchy of Luxembourg and the Netherlands stipulates that Dutch embassies are to represent Luxembourg politically in places where there is no Luxembourg embassy. This is relevant in the context of the Yugoslav crisis, because Luxembourg preceded the Netherlands as EC Presidency in 1991 and did not have an embassy of its own in Belgrade.

Outside the formal policy-making process, the European parliamentary formations of national political parties can sometimes play an important informal role in the making of European foreign policy. In these confederations of political parties, party chairmen and political leaders of likeminded parties in individual EU member states and prospective member states, meet to develop common philosophies and achieve common positions. During the early stages of the Yugoslav crisis, the European Christian Democrats, united under the European People's Party, were a particularly important group, because, at that time, they were in power in six EC member states as well as soon-to-be-member Austria. ${ }^{49}$

The Western European Union, a European defence body without material capabilities of its own, had been 'asleep' for much of the time between its creation in 1954 and 1984. After 1984, the WEU was gradually reactivated over the course of a number of ministerial meetings. ${ }^{50}$ During the Gulf War, the WEU played a role in the naval embargo against Iraq, but in the final analysis most European allies preferred to coordinate their efforts with the United States on a bilateral basis. In July 1992, NATO and WEU Ministers decided to task the WEU with a naval operation in the Adriatic in order to monitor complicance with an arms embargo against former Yugoslavia in UN Security Council Resolution 713 of 25 September 1991 and with economic sanctions imposed on the Federal Republic of Yugoslavia (Serbia and Montenegro) in UN Security Council Resolution 757 on 20 May 1992. At the present time, the movement towards a common European defence body has gained momentum with the agreement that the EU should be able to field a separate force that uses NATO facilities in situations where action is needed but US involvement does not seem likely. 


\section{The Global Dimension: NATO, the OSCE, the UN and ad hoc Groups}

The North Atlantic Treaty Organisation (NATO), founded in 1951 on the basis of a treaty signed in 1949, ties the United States, most Western European countries as well as Turkey into an intergovernmental military alliance. NATO decisions are made in the North Atlantic Council (NAC). The NAC is composed of permanent national representatives and meets at least once a week. The NAC also meets at a ministerial level (Ministers of Foreign Affairs and Ministers of Defence), as well as at the level that involves heads of state. But decisions are equally valid regardless of the level at which the NAC meets. Decisions are made on a strictly intergovernmental level and requires unanimity. An international staff headed by the Secretary-General supports the work of the NAC and its various political and military committees. NATO's political and military headquarters are both located in Belgium. SACEUR, NATO's commander-inchief for Europe, has as a rule, been an American national. NATO's involvement in the Yugoslav crisis between July 1990 and July 1995 was restricted to the provision of air power, which was to be called in at the request of the United Nations.

The Organisation for Security and Cooperation in Europe (OSCE) was founded in 1975 with the signing of the Helsinki Final Act as the Conference for Security and Cooperation in Europe (CSCE) and finally became an 'Organisation' in January 1995. It is the only platform available that deals with the European security environment and includes all European countries (except the Federal Republic of Yugoslavia, whose membership is currently frozen), plus the United States, Canada and, as observers, Japan and South Korea. The Charter of Paris of November 1990, concluded with a summit of the then 34 participating states' heads of government, created a permanent Council of Ministers. It also created the Committee of Senior Officials to prepare the ministerial meetings. At last, there is now a permanent Parliamentary Assembly, a permanent Secretariat in Prague, a Centre for Conflict Prevention in Vienna and an Office for Democratic Institutions and Human Rights (ODIHR), based in Warsaw.

The United Nations was founded in 1945, with the Netherlands as one of its original members. Its main bodies are the General Assembly, the Secu- 
rity Council and the UN Secretariat. The secretariat is headed by the UN Secretary-General. The Security Council functions as the chief decision making council. All UN member states have agreed to accept and carry out the Security Council's resolutions in accordance with the UN Charter. The Security Council consists of fifteen members, five of whom occupy a permanent seat (the United States, Britain, France, China, and Russia) and possess veto powers. The ten non-permanent members are elected by the General Assembly to serve two-year terms. The United Nations became involved in the Yugoslav crisis on 25 September 1991, when the Security Council imposed an arms embargo against the whole territory of the former Yugoslavia. Between 25 September 1991 and 28 April 1995, two months before the fall of Srebrenica, the Security Council adopted no fewer than 73 resolutions directly related to the situation in the former Yugoslavia. ${ }^{51}$ Some of the most important resolutions were resolution 743 (21 February 1992), which established the United Nations Protection Force (UNPROFOR); resolution 759 (11 December 1992), which authorised the preventive deployment of a UN force in Macedonia; resolution 819 (16 April 1993), which demanded that Srebrenica and its surroundings be treated as a safe area; resolution 824 (6 May 1993), which expanded the safe area status to include not only Srebrenica, but Sarajevo, Tuzla, Zepa, Gorazde, and Bihac; resolution 836, which gave a mandate to UNPROFOR to deter attacks against the safe areas; and resolution 844 (18 June 1993), which authorised a reinforcement of UNPROFOR to enable it to carry out resolutions 819,824 , and 836 .

Apart from formal organisations, ad hoc groups of countries also played a role in formulating international policy with regard to the Yugoslav crisis. The five countries who signed the 'Joint Action Programme' on 22 May 1993 constituted an ad hoc group, that shared interests regarding the Yugoslav crisis as the basis for its brief existence. The Contact Group, made up of the US, Britain, France, Germany, Russia and later Italy, was founded with the Yugoslav crisis specifically in mind. The Contact Group evolved out of the impatience of its members concerning more formal multilateral consultation and decision making mechanisms. In neither case had the Netherlands been invited to join, prompting protests that regular mechanisms had been bypassed. 


\section{NOTES}

1 See: C.R. Boxer, The Dutch Seaborne Empire 1600-1800 (London: Penguin, 1990).

2 See: Simon Schama, The Embarassment of Richess: An Interpretation of Dutch Culture in the Golden Age. (London: HarperCollins, 1987)

3 Alfred E. Pijpers, 'Dekolonisatie, compensatiedrang en de normalisering van de Nederlandse buitenlandse politiek' (Decolonisation, compensation urge and normalisation of Dutch foreign policy), in: N.C.F. van Sas, ed., De kracht van Nederland: Internationale positie en buitenlands beleid in historisch perspectief (The strength of the Netherlands. International position and foreign policy in historical perspective) (Haarlem: Becht, 1991).

4 Quoted in: C.J. Visser and S. Rozemond, 'Nederland en het opkomen voor mensenrechten' (The Netherlands and the fight for human rights), in: M. van Leeuwen et al., Het Woord is aan Nederland. Thema's van buitenlands beleid in de jaren 1966-1983 (The Netherlands has the floor. Foreign policy themes in the years 1966-1983, Clingendael paper) (The Hague: Sdu: 1983), pp. 204-205.

5 Scheffer, Een tevreden natie, pp. 44, 45.

6 Jan Willem Honig, 'Myths That Keep Small Powers Going', Paper for the Conference 'Mythen in den Internationalen Beziehungen', Centre Franco-Allemand de Recherches et Sciences Sociales, Berlin, 10 April 1995, p. 4.

7 J.C.H. Blom, Crisis, Bezetting en Herstel. Tien Studies over Nederland 1930-1950 (Crisis, Occupation and Recovery: Ten Studies Concerning the Netherlands 1930-1950) (The Hague: Universitaire Pers Rotterdam, 1989), p. 134.

8 Pijpers, 'Dekolonisatie' in: Van Sas, ed., Kracht, p. 213.

9 Keerpunt 1972. Regeerakkoord van de progressieve drie, (Turning Point 1972: Government Manifesto of the Progressive Three), p. 7.

10 D. Bol, quoted in: Hellema, Buitenlandse politiek, p. 278.

11 There is one interesting anecdote related to the Dutch participation in the NATO air operations over Bosnia in 1995. Dutch squadrons usually carry a provincial flag next to the national flag. One of the squadrons thus carries a red and white chequered flag that is virtually identical to the Croatian national flag. When jets from this squadron participated in air raids over the Serb-held town of Foca, attacking a number of bridges there, the rumour quickly spread among Bosnian Serbs that the Croatian air force had bombed Foca.

12 See: Jelle Visser and Anton Hemerijck, A Dutch Miracle. Job Growth, Welfare Reform and Corporatism in the Netherlands (Amsterdam: Amsterdam University Press, 1997).

13 Voorhoeve, Peace, Profits and Principles, p. 56. 
14 Everts and Walraven, eds., The Politics of Persuasion. Implementation of Foreign Policy by the Netherlands (Aldershot: Gower, 1989), p. 103.

15 Honig, Defense Policy, p. 234.

16 Motie-Brinkhorst, in: HTK, 1979, 15441, no.7.

17 Drea Berghorst, Very Good News. De besluitvorming over de uitzending van een luchtmobiel bataljon naar Bosnië-Herzegovina (Very Good News: The decision making regarding the deployment of an airmobile battalion to Bosnia-Herzegovina), MA thesis, 1996 NGIZ award, Free University of Amsterdam, July 1995, p. 34 .

18 Richard C. Eichenberg, 'The Myth of Hollanditis', International Security, Autumn 1993, p. 145.

19 Interview Jan Hoekema, The Hague, 4 February 1997.

20 Voorhoeve, Peace, Profits and Principles, p. 57.

21 Everts and Walraven, Politics of Persuasion, p. 88.

22 Interview Relus ter Beek, Assen, 4 July 1997.

23 Voorhoeve, Peace, Profits and Principles, p. 77.

24 Most recently by Voorhoeve: NRC-Handelsblad, 6 March 1998.

25 James A. Baker III, with Thomas M. DeFrank, The Politics of Diplomacy: Revolution, War \& Peace, 1989-1992 (New York: G.P. Putnam's Sons, 1995), pp. 89-90.

26 See: Oppewal and Seroo, 'Dubbel interview', Internationale Samenwerking, pp. 20-25.

27 Honig, Defense Policy, p. 144.

28 Everts and Walraven, p. 89.

29 De Volkskrant, 2 March 1993.

30 Voorhoeve, Peace, Profits and Principles, p. 58.

31 Interview Mr. F.A.M. Majoor, The Hague, 10 July 1997.

32 Everts and Walraven, p. 73.

33 Interview Hanno Würzner, The Hague, 21 September 1999.

34 Henry Wijnaendts, Joegoslavische Kroniek Juli 1991 - Augustus 1992, Amsterdam: Rap, 1993.

35 H.A. Couzy, Mijn jaren als bevelhebber (My years as Commander) (Amsterdam: L.J.Veen, 1996), p. 17.

36 Interview Bert Kreemers, The Hague, 19 June 1997.

37 Couzy, Mijn jaren als bevelhebber, p. 14.

38 See: Jan van der Meulen, 'Einde Missie?' (End of Mission?), Maatschappij en Krijgsmacht, Vol. 17, no. 4, August 1995, pp. 3-6.

39 Christopher Hill and William Wallace, 'Actors and Actions', in: Christopher Hill, ed., The Actors in Europe's Foreign Policy (London: Routledge, 1996), p. 5. 
40 Juliet Lodge, ed., The European Community and the challenge of the future, 2nd ed. (London: Pinter, 1993), p. 228.

41 Stephen George, Politics and Policy in the European Union, 2nd ed. (Oxford: University Press, 1991), p. 218.

42 Quoted in: Fiona Hayes-Renshaw and Helen Wallace, The Council of Ministers (London: MacMillan, 1997), p. 52.

43 Hayes-Renshaw and Wallace, p. 161.

44 Ibid., p. 165.

45 Hayes-Renshaw and Wallace, Council of Ministers, p. 164.

46 George, Politics and Policy, p. 221.

47 Hayes-Renshaw and Wallace, p. 168.

48 Ibid., p. 93.

49 See: Thomas Jansen, Die Entstehung einer Europäischen Partei. Vorgeschichte, Gründung und Entwicklung der EVP (Bonn: Europea Union Verlag), 1996.

50 Lodge, The European Community, pp. 258-259.

51 The United Nations and the Situation in the Former Yugoslavia. Resolutions of the Security Council and Statements by its President, 25 September 1991-28 April 1995; (New York: UN Department of Public Information, April 1995). 


\section{An Emerging Challenge, July 1990 - June 1991}

By July 1990, Yugoslavia was in deep crisis, although most European governments did not notice it. In the various elections that had taken place in the individual Yugoslav republics during the second half of 1990, communists-turned-nationalists, or anti-communist nationalists had won overwhelming victories. 'Yugoslavia no longer exists', declared Slovene Foreign Minister Dimitrij Rupel in July 1990, having just been voted into power as part of the pro-independence coalition DEMOS. ${ }^{1}$ In the Serbian province of Kosovo, ethnic Albanians declared that Kosovo would no longer be a province in Serbia but one of the federation's constituent republics. Kosovo's autonomy had already been withdrawn by Serbian President Milosevic and the two Kosovar representatives purged from the federal Presidency. The year 1990 saw further purges of leading Albanians from their positions. Both Slovenia and Croatia demanded that Yugoslavia be restructured into a confederation of sovereign states. Croatian Serbs, in turn, declared that if Croatia were to become independent, they should be given the right to secede from Croatia and remain part of Yugoslavia. The Croatian government responded by sending its own special police into ethnically mixed Serb-Croat areas to replace the existing police. A violent incident between Croatian Serbs and Croats took place as early as September 1990 in the Croatian town of Glina, followed by shoot-outs in Pakrac and in Plitvice National Park in March 1991. In the meantime, various rounds of negotiations between the republics failed to produce reconciliation. A serious clash between Croatian policemen and Serb militiamen on May 2, 1991, in the Croatian village of Borovo Selo finally put the Yugoslav crisis on the international-political map. When 
Serbia subsequently blocked the regular rotation of the Yugoslav federal Presidency to the Croat Stipe Mesic (elected in 2000 as Croatian President on a reformist ticket), the Yugoslav crisis had become a serious foreign policy issue for Europe and America.

Turning to the international environment surrounding the Yugoslav crisis, one sees three organisations dominating the scene between July 1990 and June 1991. These were the CSCE (later: OSCE) through its principles and norms covering the relations between its member states, the EC (later: EU) through its European Political Cooperation (EPC), as well as NATO, through which the USA managed European security.

The external constraints placed by CSCE, EPC and NATO on their members were strong. They were felt all the more strongly in the Netherlands, a country whose foreign policy élite upheld the notion that international regimes were by definition beneficial to its security and status. The prospect of holding the EC Presidency during the second half of 1991, with the responsibility of chairing an Intergovernmental Conference on a treaty for a real EU, reinforced the Dutch self-perceived role as champion of supranational European integration. If there was a specifically Dutch foreign policy aimed at dealing with the Yugoslav crisis during this period, it only existed as part of various regime-building exercises. In other words, any activity directed towards the Yugoslav crisis at this stage was essentially a by-product of the broader aim of creating the EU.

Two additional factors should be borne in mind, the first of which is that Dutch policy with regard to the emerging Yugoslav crisis was the exclusive affair of the Foreign Ministry, as the public simply did not have an opinion on the issue yet. Secondly, the question of whether the Netherlands exerted influence at this stage of the crisis is not relevant, given that during its opening phase this was not an issue on which any government desired to be influential, but more like a hot potato which governments sought to pass off to each other.

The first half of this chapter is devoted to the policy-making process in the Dutch Ministry of Foreign Affairs regarding the emerging Yugoslav crisis. It will describe the warnings emanating from various quarters and the lack of a serious response to these warnings by the political leadership. The second half will show that this absence of a concrete response 
must be understood in the context of the international environment in which the Dutch Foreign Ministry operated. In particular, the EuroAmerican consensus that the principle of territorial integrity should be at the centre of diplomacy served as a tight constraint on Dutch policy.

\section{Early Warnings}

Nothing better illustrates how long the Yugoslav crisis remained unwanted as a political issue than the failure of the regional experts in the Dutch diplomatic service to obtain a serious hearing for their assessments from their bureaucratic and political superiors. The failure by the EC and the US to deal with the Yugoslav crisis with more rigour at an earlier stage was not due to a lack of intelligence information. The early-warning system itself worked on both sides of the Atlantic. In November 1990 the US intelligence community presented the Bush administration with a complete National Intelligence Estimate (NIE) on Yugoslavia's approachng disintegration. The NIE warned of 'a Serbian quest for hegemony within Yugoslavia, a popular desire on the part of many Slovenians, Croats, and others for a looser federation and, barring that, for independence, depth of feelings of the people of Yugoslavia and the likelihood of brutality', and 'the impossibility of maintaining the unity of Yugoslavia.' However, the co-ordinator of the American team that had written the NIE, DutchAmerican Marten van Heuven, later explained that 'nobody was glad to get this predictive assessment' and, worse, that it was 'ignored'. The main reason for the hesitant Western response was distraction by other foreign policy issues: the possibility of a collapse of the Soviet Union; the Gulf conflict of 1990-1991; a partial US withdrawal from Europe; German reunification; and the process of European integration in the run-up to the establishment of a European Union. ${ }^{3}$ All these issues seemed more important than the Yugoslav crisis. The collective mistake of the West, then, was not so much a failure to recognise that the Yugoslav federation was in crisis but to underestimate its potential for posing a fundamental challenge to the new post-Cold War international order.

The staff that occupied the Dutch Embassy in Belgrade on the eve of the Yugoslav wars of dissolution cannot be accused of grossly misinterpreting or misrepresenting developments in the Socialist Federative Republic of Yugoslavia in 1990 and early 1991. Nor, in fairness, can the Embassy be said to have been slow or lazy in its reporting. Moreover, if the Dutch 
Ambassador was one of the EC Ambassadors whom German journalist Viktor Meier argues were 'arrogant', even 'hostile', towards the independence-seeking Yugoslav republics of Slovenia and Croatia, this was due in the first place to instructions emanating from The Hague. ${ }^{4}$

'Dark clouds are gathering above the multinational state of Yugoslavia... The continued existence of the (con)federation as a viable state seems to be hanging from a silk thread. This warning was sent to the Dutch Ministry of Foreign Affairs in The Hague by the Dutch Ambassador in Belgrade, Albert Nooij, on July 23, 1990. Nooij had been given a new assignment and had just paid farewell visits to Croatian leaders in Zagreb and Serbian leaders in Belgrade. Two days earlier, Nooij had reported his conversation with Serbian Foreign Minister Dr Prlja. Quoting Prlja, Nooij had written: 'Serbia will not let itself be forced by Slovenia and Croatia into a confederate governmental structure. Those republics will not succeed in pushing the always underprivileged Serbia down to its knees through economic means of coercion. Serbia has shown before that it can survive on its own and will do so, albeit with difficulty, in future. The Serbs are... pessimistic about the continued existence of a viable Yugoslavia.'

The difficult conversations with Serbian and Croatian politicians led Nooij to conclude that the differences between Serbia and Croatia 'had deteriorated to the extent that there was in fact no longer a basis for a continued common existence'. He assessed that a possible scenario was the break-up of Yugoslavia into a confederacy encompassing Slovenia, Croatia and possibly (a part of) Bosnia-Herzegovina, and a greater Serbia encompassing the provinces of Kosovo and Vojvodina, Montenegro and possibly the rest of Bosnia-Herzegovina. (It was unclear how Macedonia fitted into this.) Nooij explained that it was uncertain how this would come about. Serbian president Milosevic had emphasised, Nooij continued, that in that case the borders between the republics would have to be revised - by force if need be - so that every Serb again lived in Serbia without, Nooij stressed, having to leave his present home in Croatia or Bosnia-Herzegovina. Croatian President Tudjman would in that case probably want the same for 'his' Croats.

On August 18 the Embassy in Belgrade sent another warning to The Hague. Following the departure of Ambassador Nooij, the Chargé 
d'Affaires, Dirk Hasselman, was running the Embassy. Hasselman had been posted in Yugoslavia for nearly three years and was very pessimistic about its future. ${ }^{5}$ In his message he warned that the silk thread on which the survival of the Yugoslav federation was still hanging, was about to break. The three most important indications for this, according to Hasselman, constituted a strike by the Albanian community in Kosovo, a decision by Slovenia that its conscripts could no longer serve outside Slovenia and Croatia, and a referendum on independence among the Serbs in Croatia, which was to be held the next day.

During the winter months of 1990, the Embassy temporarily moderated its alarmist stance. On October 3, the day of German reunification, it began to operate under a new Ambassador, Jan Fietelaars. Fietelaars had been prepared and briefed in The Hague. There, the atmosphere had been optimistic: a new European order was said to be coming about as a result of the end of the Cold War. Many Central and Eastern European countries would join up with the European Community, which was soon to become a full-blown economic and political union. Yugoslavia, Fietelaars had been told, would become a member state following a large financial injection to help it service its international debt. Moreover, Fietelaars had been prepared for his job in the classical way, obtaining much of his information from standard textbooks and the Yugoslav Embassy in The Hague, whose information was, however, unreliable, given that it was run by 'a frightened Slovene who stuck precisely to the Communist party-line'. ${ }^{6}$ As a result, Ambassador Fietelaars initially underestimated the depth of the Yugoslav crisis and its potential for largescale violence.

While Hasselman disagreed with Fietelaars, the reporting from Belgrade temporarily sounded less gloomy than before. Thus, on October 19, following a meeting of all EC Ambassadors in Belgrade, Fietelaars sent an evaluation of recent developments. In its conclusion, which Fietelaars argued was shared by all the Ambassadors, he stated that the process of Yugoslavia's disintegration was reaching its final stage and that a long period of negotiations for a new form of cooperation between the Yugoslav republics was about to begin. He concluded: 'Particularly at the start of these, the regression, the theatre and the violent incidents may continue to take place. But one can say that civil war and extreme violence remain unlikely.' 
Fietelaars' more optimistic view may have influenced attitudes in The Hague, although it is impossible to know to what degree. If it did influence attitudes, its main effect would have been to confirm an already existing complacency and disinterest. In any case, Fietelaars soon realised that Hasselman's pessimism was justified. 'Within the space of three months he had completely converted me. His analyses and predictions were correct. So I began to think differently. By the end of December 1990/ early January 1991 I had come round and said: "something very nasty is going to happen here." And it was in that sense that we began to report. ${ }^{17}$ One of the clearest hints of what was yet to come was given by President Milosevic himself in a lunch meeting with Ambassadors from the EC on January 16, 1991. According to the report from Belgrade, Milosevic had made it clear that if Yugoslavia were allowed to break up, Serbia would seek to carve out a new state for itself. This new state would not be restricted to the territory of the constituent republic of Serbia. Milosevic said that he was ready to let Slovenia go and that Macedonia was still under discussion. However, he wanted to be absolutely clear about the Serb-inhabited parts of Bosnia-Herzegovina and Croatia: they would be part of the new state. He explicitly warned the Ambassadors: 'If this is not attainable peacefully, one forces Serbia to use the tools of power which we possess, but they [the other republics] do not.' As the crisis developed into a war, Fietelaars understandably became an outspoken advocate of a forceful international intervention, including a military component, against Serbia and the Yugoslav army.

The second group of officials trying to put the Yugoslav crisis on the political map were the three people who made up the Eastern Europe Division in the Ministry in The Hague, in particular Harm Hazewinkel and Ellen Berends, the respective head and deputy-head of the division. While the Embassy and the Eastern European Division worked in tandem to push Yugoslavia as a foreign policy issue, the Eastern European Division did not share the Embassy's interventionist stance. By the time the Netherlands succeeded Luxembourg as holder of the EC Presidency, the Embassy and the Eastern European Division had begun to part company on the question of intervention, with the latter favouring a managed disintegration including, if necessary, border changes between the various republics. 
Between July 1990 and June 1991 the Eastern European Division, like the Embassy, tried hard to capture the attention of the bureaucratic and political leadership for developments in Yugoslavia. Thus, in a clear sign of support of Ambassador Nooij's early warning, Ellen Berends, the Division's deputy-head, wrote a telegram to the Dutch permanent representation at NATO, warning: 'On this side too it is judged that the situation in Yugoslavia is very explosive and that there is a real danger of a break-up of the federation.' Berends posed 'the question of whether the West possessed the means to stop such a development' and argued:

'Although with the break-up of the federation the danger of (armed) conflicts between the former constituent parts of the federation is real, increasingly the question seems justified of whether preserving the unity of the federation at all costs results in a much more stable situation. One is increasingly under the impression that federal cooperation in the federation has simply ceased to exist, and it is doubtful whether the central government will then possess the means to keep alive this federation, other than through the use of force.'

The message was timely and correct and was followed by numerous other warnings. Despite Fietelaars' initial optimism between October-December 1990, the Eastern European Division did not divert from its pessimistic line. On October 23, the Division warned: 'A break-up of Yugoslavia, however little desirable from the Western point of view, remains one of the possibilities. Already, the country is largely being kept together by negative considerations.'

An important reason for why the Eastern European Division adopted a line in favour of a 'managed disintegration' was that Hazewinkel and Berends believed that in the Yugoslav context, the principle of territorial integrity came with continued authoritarianism. ${ }^{8}$ It would turn out later that theirs was a minority position. But for now, what was important was that the Division sketched the dilemma and presented it to the DirectorGeneral for Political Affairs and the Minister of Foreign Affairs. The dilemma was sketched in a note, signed by the Director for European Affairs but drafted by the Eastern Europe Division, for the attention of the Director-General for Political Affairs for a meeting of the Political Committee on November 14 and 15, 1990. The note reflected a German intervention to the same effect made several days earlier in NATO and read: 
...one will, by the way, not be able in the future to ignore the question of which choice must be made, if it were to turn out that democracy and human rights would be better served by a partitioning of the country than by holding on to the unitary state. The way things are now, the greatest advocates of unity in Yugoslavia do not seem to be the greatest advocates of democracy.

Several months later, in April 1991, the Eastern Europe Division launched another small-scale campaign to impress their Minister of the urgency of the situation in Yugoslavia. In minutes for a General Affairs Council on April 8, Hazewinkel and Berends warned Van den Broek that the situation in Yugoslavia was worsening and that civil war was far from inconceivable. The officials also questioned the utility of the Western reliance on Yugoslavia's Federal Prime Minister Ante Markovic, whose power base, Hazewinkel and Berends argued, had to a large measure been eroded. A week later, in preparation for a General Affairs Council on April 15, the Eastern Europe Division began to sound somewhat desperate as they asked Van den Broek: 'How realistic is the hope for an undivided Yugoslavia in the light of the Slovene determination to realise, through secession, its endeavour to achieve independence no later than coming July, as well as the increasingly far-reaching tendency that is now notable in all individual republics? In the file for yet another (informal) ministerial meeting, which took place in Mondorf-les-Bains, Luxembourg, on April 27 and 28, the Eastern Europe Division again questioned the realism of the European approach:

The chance of a solution, whereby Yugoslavia continues to exist with a central authority that deserves such a name at all, is getting smaller and smaller... The Twelve have consistently... held the position that the territorial integrity and unity of Yugoslavia must be preserved. The question nevertheless has to be asked whether a point will be reached, or perhaps is already near, where the only possibility is to manage the disintegration of Yugoslavia in such a way that bloodshed is prevented and a part of the federal structure possibly preserved. 
The Eastern Europe Division had not sounded so desperate before, and understandably so. For within the space of two weeks Yugoslavia suddenly and belatedly did become an acute foreign policy issue for the EC Ministers of Foreign Affairs. However, this was not the result of a shift in the body of opinion among the Ministers regarding the wisdom of continued support for Yugoslavia's territorial integrity, but because a constitutional crisis in Yugoslavia made clear that the possibility of disintegration was more than just an academic speculation.

\section{The Response}

The regional experts believed, to their great frustration, that the bureaucratic and political leadership had not taken their early warnings seriously. Looking back on this period, Berends commented: 'Even though we tried to sell our views to anyone who would listen, the general response was: "you must be exaggerating".' 9 As for their minutes and memoranda, Berends and Hazewinkel once mockingly suggested their superiors had seemed less interested in what they had written than in the colour of the paper they had used. ${ }^{10}$

Similarly, Ambassador Fietelaars bitterly complained that he had been unable to convince the Ministry in The Hague of the urgency of the situation in Yugoslavia. According to Fietelaars, his reports were either ignored or dismissed: 'Initially, the reaction was: "You are too closely involved. Get some distance and let it cool down for a while." I jammed the radio; I was a buzzing bumblebee flying around someone's head, and distracted from the work everyone was occupied with. I honestly never succeeded in convincing The Hague. The department found our predictions exaggerated and Cassandra-like.' ${ }^{11}$

Given that their views did not translate into policy, it is understandable that the Yugoslavia-experts assumed they were not being taken seriously. The question remains of whether this assumption is valid. The frustration shared by all those who sounded the alarm is based on the belief that their written messages, their main channel of communication to senior officials and the Minister, were read either superficially or not at all. In other words, the Yugoslav crisis was ignored, they argue, because Yugoslavia was not considered important. If this is true, then the Netherlands and, perhaps, other EC member states compounded errors made in 
the USA during this period by treating the Yugoslav crisis with a degree of misplaced arrogance. For, regarding the USA, former National Security Staff member David Gompert argues that the absence of a serious response by the US administration to early and correct intelligence information about the Yugoslav crisis, was not due to an unwillingness to take this information seriously. 'Rather, despite considerable deliberation and diplomatic action, no good option emerged to arrest the accelerating, awful logic of break-up and war.'12

The three obvious targets for the attempts by the Embassy and the Eastern Europe Division to have the Yugoslav crisis recognised as a priority foreign policy issue were, apart from the Foreign Minister himself, the Director-General for Political Affairs and the Atlantic Security and Cooperation Affairs Department (DAV). Of these three (groups of) actors, it seems that the Director-General for Political Affairs was the first to become seriously engaged with the issue.

On the eve of 'the Yugoslav war of dissolution', despite the need for a new perspective on Central and Eastern Europe, the Dutch Foreign Ministry still very much reflected Cold War traditions, both in terms of bureaucratic structure and general mentality. Inside the Ministry, three foreign policy themes had long outweighed all others in importance to the extent that they had become veritable ideologies. These were loyalty to NATO and the USA, the building of a supranational European economic and political union, and, third, the promotion of international order and society. In none of these three foreign policy themes had a place been reserved for the countries of Central and Eastern Europe, all of whom had been tossed into a single basket labelled 'Warsaw Pact'. The primacy of these three policy themes and the corresponding lack of real interest in Central and Eastern Europe were reflected in the structure of the Ministry. The functional departments focusing on NATO, EC/EU and UN affairs, not to mention the various departments in the Directorate-General for International Cooperation [development aid] had become much more important than the regional desks responsible for bilateral political relations. This made it possible that on the eve of the Yugoslav war, only three officials were responsible for relations with Central and Eastern European countries, including the Soviet Union. ${ }^{13}$ 
Without the help of more powerful departments, the Embassy in Belgrade and the Eastern Europe Division carried insufficient bureaucratic clout to serve as catalysts for an active approach towards the Yugoslav crisis. The obvious department to help the Embassy and the Eastern Europe Division, would have been DAV. Responsible for NATO, WEU and CSCE affairs, DAV could always count on being listened to by the Director-General for Political Affairs and his deputy as well as, crucially, by the Minister. The head and deputy-head of DAV, while formally ranked below the Director-General for Political Affairs and his deputy, during times of crisis were heavily relied upon for advice concerning political-strategic and military-strategic matters.

DAV remained aloof from the Yugoslav crisis until after war had already broken out. While the DAV officials naturally received copies of the relevant messages regarding Yugoslavia, there had been no serious discussions between the officials of DAV and the Eastern Europe Division regarding Yugoslavia. Hazewinkel and Berends mentioned 'compartmentalisation' of the Ministry as one of the causes. Rather than face the great changes of 1989-1991 together, officials spent much time and energy on 'co-ordination' and 'conflicts'. The bureaucratic leadership of the Ministry was said to have promoted bureaucratic conflict by openly stimulating 'competition between the directorates', rather than e.g. creating a single 'task force' to develop a coherent approach to the new situation in Central and Eastern Europe. ${ }^{14}$

According to Herman Schaper, Deputy-Head of DAV in 1990-1991, critics are right to point out that DAV was not involved enough in developing a policy for the Yugoslav crisis. However, Schaper believes that this passivity on the part of DAV was not caused by arrogance or bureaucratic conflict but by institutional constraints, political priorities and the absence of credible policy options. As Schaper puts it, from the perspective of the USA and, by extension, the Netherlands, developments in the Soviet Union were 'much more important' than developments in the Balkans. 'Yugoslavia was a sideshow', both for him and his colleagues as well as for Foreign Minister Hans van den Broek. ${ }^{15}$ While 'the Eastern Europe Division's analyses were fine', the question remained 'what to do about it. It was clear that the existing approach was not working, but was one supposed to promote fragmentation? The answer was "no" because Yugoslavia was not to set a precedent for the Soviet Union. ${ }^{16}$ 
Apart from the fact that Yugoslavia was regarded as a sideshow to the possible disintegration of the Soviet Union and was not to function as a precedent, institutional constraints also played a role. According to Schaper, the 'warnings emanating from Belgrade' did at one point trigger the question of 'whether we should have a look at Yugoslavia'. But, Schaper explained, 'Yugoslavia lay outside the NATO area and therefore was not our subject'. Moreover, Schaper and his staff were 'very busy with Maastricht and the CSCE. We were working sixty to seventy hours per week. That is why, for me, the most important lesson of this period is: "The immediate drives out the important." 17 Schaper acknowledged there had also been a denial of the problem: 'Following Tito's death we had heard many times that Yugoslavia would fall apart. The military were training for the possible start of a Third World War in Yugoslavia. We were hoping so hard that nothing would happen that we did not want to think about it too hard.'18

The Director-General for Political Affairs (equal to the 'Political Director' in most countries' Ministries of Foreign Affairs), Peter van Walsum, began to critically review existing EC policy with regard to the Yugoslav crisis in February 1991. While late in the day, this was some three months before Van den Broek and the other EC Foreign Ministers began to regard the Yugoslav crisis as a serious issue. According to Van Walsum, if the regional experts believed their warnings about Yugoslavia went unnoticed between July 1990 and June 1991, they were wrong: 'Because since Tito's death everyone had really been waiting for the disintegration of Yugoslavia, the admonitions by the Eastern Europe Division were not exactly hot news.' ${ }^{19}$

Like Schaper, Van Walsum believes that, rather than disinterest or distraction, a combination of political priorities and institutional constraints made it hard for Dutch officials to formulate a credible response to the Yugoslav crisis. The main political priority after the end of the Cold War was, it seemed, to prevent fragmentation and preserve as much as possible the territorial status quo in Central and Eastern Europe. In Van Walsum's words, 'that one had to try to keep the country [Yugoslavia] together for as long as possible was a kind of dogma for the [EC foreign] Ministers'. ${ }^{20}$ At the institutional level, Van Walsum argues, Dutch policy was formulated within a framework where more powerful countries, the USA in particular, assumed that it was both desirable and possible to keep 
Yugoslavia together as a country. On that basis, the US and other Western countries gave priority to territorial integrity over the right to self-determination. As for the EC, Van Walsum argues that Dutch foreign policy was constrained by the fact that the EC member states, including the Netherlands, were not so much driven by a shared desire for effective policy as by a shared desire for consensus. ${ }^{21}$

In fact, Peter van Walsum, who had been appointed Director-General for Political Affairs in 1989, was more receptive than most to the warnings emanating from the Eastern Europe Division. Having served in Bucharest from 1967 until 1970, Van Walsum had travelled through all of SouthEastern Europe. He strongly believed that provisions for minority rights alone could not solve the nationality question of Yugoslavia. For that reason, as the Yugoslav crisis deepened, Van Walsum 'did not feel at all comfortable with our [the EC's and the Dutch] unconditional support for the unity of Yugoslavia.'22

Despite Van Walsum's scepticism about the realism of continued Western support for Yugoslavia's territorial integrity, it took until February 1991 for him to become seriously engaged over the issue. Thus, the Eastern Europe Division's note of November 1990, which sketched the dilemma that democracy and human rights might not go together well with territorial integrity, had not inspired Van Walsum to make an intervention in the ensuing meeting of the Committee of Political Directors. Instead, the political directors had 'solved' the dilemma by concluding that the EC should continue to support the Yugoslav federal authorities led by Prime Minister Ante Markovic. Several months later, however, he made this very point in meetings with EC and US officials. Something had obviously happened to focus his mind more closely on the Yugoslav problem.

What really sparked Van Walsum's interest was a visit to The Hague by Slovene Prime Minister Lojze Peterle and Foreign Minister Dimitrij Rupel on February 12 and 13, 1991. While the invitation to Peterle and Rupel had come from a Dutch employers union, meetings had also been scheduled with Foreign Minister Van den Broek and Prime Minister Ruud Lubbers. However, a few days before the arrival of the Slovene politicians, their meeting with Van den Broek was cancelled and replaced by a meeting with Van Walsum. The reason for the cancellation was that Van den 
Broek decided that the meeting clashed with the agreed EC strategy of formally distinguishing between Yugoslavia's federal and republican leaderships, as part of the overall EC policy of support for the territorial integrity and sovereignty of the Yugoslav federation. Van den Broek's Belgian colleague, Mark Eyskens, also cancelled his meeting with Peterle. For his part, Prime Minister Lubbers decided to receive Peterle nonetheless, having changed the format of the meeting from one between heads of government into one between members of the Christian-Democrat European People's Party.

Van Walsum was taken aback by what he viewed as the ruthless determination with which the Slovenes seemed to be striving for independence. ${ }^{23}$ According to Hazewinkel, the 'outright irresponsibility and indifference of the Slovenes regarding the rest of Yugoslavia' struck the Dutch officials who attended the meeting. ${ }^{24}$ According to Dutch minutes of the meeting Peterle said that the Yugoslav conflict should be 'internationalised' and that Slovenia and other republics 'should be recognised by the EC when they became independent'. He said that he 'regretted' that the international community, which had 'initially cheered for democracy, was now reluctant. He did not believe it likely that violence would occur in Slovenia. He believed there could be fighting between Serbs and Croats in Croatia, but 'this did not seem to worry him'. Peterle argued that those republics that were in the process of democratic reforms ought already to be given a clear prospect of membership of organisations like EFTA or the Council of Europe. The overall impression left on the Dutch was that 'Slovenia would in any event want to declare its independence, regardless of the consequences this could have for other individual republics, even if it would be accompanied by violence.'

The Peterle visit marked a turn in Van Walsum's thinking. While he had been careful to stay well within official policy during the meeting, the confrontation with Slovene nationalism convinced him that the EC policy of support for Yugoslavia's territorial integrity would neither stop Slovenia from declaring independence, nor prevent the rest of Yugoslavia from falling apart. ${ }^{25}$ During the meeting itself, Van Walsum had pointed out to Peterle that it would be difficult for the EC member states 'to differentiate within states', meaning that it would not be easy to offer individual Yugoslav republics the prospect of membership of international bodies as long as the Yugoslav federation was an internationally 
recognised sovereign state. It later turned out turned out that Van Walsum's careful wording had convinced the Slovenes that the Netherlands was much less supportive of their cause than Belgium and Germany. For, upon Peterle's return to Ljubljana, the honorary consul in Ljubljana, Matija Skof, informed the Dutch embassy in Belgrade, that the meetings in the Netherlands had been disappointing. The Slovene interpretation was correct to the extent that the Dutch government remained firmly within the EC/NATO consensus on support for Yugoslavia's territorial integrity. Van Walsum, however, was increasingly doubtful that this consensus was built on the right assumptions. He began to air divergent personal views in meetings with EC and US officials. ${ }^{26}$

The first occasion for Van Walsum to express his doubts was a visit to The Hague by a senior US official. The USA at this point in time had launched a veritable campaign for greater action on the part of the Europeans to do more to prevent a crisis in Yugoslavia and preserve the country's territorial integrity. Thus, on February 27,1991 US Principal Deputy Assistant Secretary of State for European and Canadian affairs, James Dobbins, visited The Hague as part of a tour around several EC member states. Washington, Dobbins explained, would like to see the EC member states take on a more active role. The existing policy of support for Yugoslavia's territorial integrity, Dobbins added, needed to be maintained as it was certain that the alternative, disintegration, would trigger a civil war. Van Walsum, however, referred to the recent visit by Peterle and said that in the EC the fear was growing that stressing the integrity of Yugoslavia was a lost cause'. He added that there was some hesitation in the EC to take up too strong a position, because one did not want to 'identify oneself beforehand with all the means that Belgrade might resort to in order to maintain the country's unity. After all, it was mostly precisely those with the worst human rights record who championed the unity of the federation most strongly.'

Three weeks after the meeting in February, there was another opportunity for Van Walsum to share his views directly with the US administration. An EPC Troika, consisting of Van Walsum and his Italian and Luxembourg counterparts, visited Washington on March 21 and again met with Dobbins. Dobbins repeated the criticism that the EC had not sufficiently exploited its capacity to influence Yugoslavia. The Italian Political Director conceded that the Europeans had been 'slow' in their reaction. But 
Van Walsum disagreed and said that 'it was not so much European sluggishness which was an obstacle but the dilemma that in Yugoslavia the proponents of unity as a rule were not the greatest proponents of democratic and economic reforms.'

Clearly the dilemma sketched in the Eastern Europe Division's note of November 1990, namely that democracy and territorial integrity could perhaps not be supported at the same time, were now part of Van Walsum's own reasoning. However, according to Van Walsum, his interventions were 'fruitless.'. ${ }^{27}$ Political reality dictated that the Netherlands should remain within the EC/US consensus and this consensus centred on a policy of support for the territorial integrity of the Yugoslav federation.

According to Foreign Minister Hans van den Broek, 'before May 1991, Yugoslavia was not a topic for discussion among the EC Ministers of Foreign Affairs. ${ }^{28}$ While mentioned in ministerial declarations, the Ministers themselves did not actually discuss Yugoslavia until its constitutional crisis placed the country on the diplomatic agenda in May 1991. Given this general lack of interest, there were few incentives for Van den Broek to take the warnings emanating from within his Ministry too seriously.

When Yugoslavia was mentioned in ministerial meetings, Van den Broek adopted a low profile, despite the warnings emanating from within the Ministry. Van den Broek felt he could not speak freely on the issue of Yugoslavia's potential disintegration. The reason was that Yugoslavia was always discussed in the context of the potential disintegration of the Soviet Union and the desire of the Baltic States to become independent. With regard to the Baltic States, Van den Broek was hampered by what he regarded as an embarrassing historical legacy on the part of the Netherlands. ${ }^{29}$ In 1942, when the exiled Dutch government had entered into official diplomatic relations with the Soviet Union, it had implicitly recognised the Soviet annexation of the Baltic States by not making a reservation regarding this issue. Most Western states had not recognised the Soviet annexation. Given the Netherlands' formal recognition of the Soviet Union's annexation of the Baltic States, Van den Broek felt the Dutch government could not openly support the Baltic states in their quest for independence. 
Another reason for Van den Broek not to bring up his officials' concerns about Yugoslavia's potential disintegration in ministerial meetings was his basic agreement with the general Western approach to the disintegration of the Soviet empire, which was to preserve the status quo as much as possible. To preserve the status quo meant giving primacy to the principle of territorial integrity over the principle of the right to self-determination. Van den Broek later reflected: 'My thinking, with the majority of EC member states was fed by the idea "fragmentation, my god, what is that going to be?" [US Secretary of State] Jim Baker was also of that opinion. The aim was to prevent a fragmentation of Yugoslavia because of the unforeseeable consequences of a splintering of Europe, of which this could prove to be the beginning. "Imagine", we said, "that the whole of Europe would partition itself along ethnic lines", that was a nightmarescenario.' ${ }^{30}$

A third and final reason explaining Van den Broek's apparent indifference regarding the Yugoslav crisis in 1990 and early 1991 was his focus on other policy questions. For Van den Broek the questions of European integration and NATO cohesion were far more important than developments in Yugoslavia. ${ }^{31}$ This also meant that Van den Broek was less interested in the quality of a Dutch response to the Yugoslav crisis than in the perceived need to be in the mainstream of collective European and transatlantic approaches. Indeed, so well known was Van den Broek's loyalty to NATO that the following joke was sometimes heard in European diplomatic circles: 'The USA does not need its embassies in Europe, given that it already has the Netherlands to champion its interests.' US Secretary of State James Baker recognised as important the role Van den Broek played in Europe as a defender of common Atlantic interests and as a bridge-builder between Europe and the USA. Having toured all of Europe in early 1989 to discuss the modernisation and reduction of short-range nuclear arms, Baker concluded: 'Yet of all my stops... it was my meeting in the Netherlands with Foreign Minister Hans van den Broek that may have been the most important of all... He passed me a paper with some ideas. Conceptually, he was right, and it was the first time, but far from the last, that I would see this astute statesman suggest a solution to diplomatic deadlock. ${ }^{32}$

Not surprisingly therefore, Van den Broek's first explicit intervention in EPC in the context of the Yugoslav crisis dealt with procedure, not the 
actual crisis. On June 17, 1991, he opposed a proposal by the Luxembourg Presidency to organise an ad hoc gathering in the margins of the upcoming CSCE ministerial Council meeting to be held in Berlin on June 19 and 20. The gathering was intended to bring the non-EC member states Austria and Hungary in line with EC and US policy. The two countries had adopted positions in support of the independence-seeking Yugoslav republics of Slovenia and Croatia, which clashed with the EC and US emphasis on Yugoslavia's territorial integrity. ${ }^{33}$ The Luxembourg Presidency proposed to hold a meeting between the EC Presidency, the European Commission, Italy, Greece, the USA, Hungary and Austria. However, Van den Broek, supported by his French and Spanish colleagues, declared that he opposed the Luxembourg idea, not because of the intended pressure on Austria and Hungary but because of the proposed format of the meeting, which would include two member states, Italy and Greece, on purely geographical grounds. Instead, he proposed a meeting of only the EC Presidency, the USA and Austria and Hungary. Van den Broek had his way: it was decided that only the EC Presidency and the European Commission would join the US in the meeting with Austria and Hungary.

The policy of supporting Yugoslavia's territorial integrity was kept up ad absurdum. Hence, when the declarations of independence by Slovenia and Croatia were issued, the Netherlands had difficulty in devising a diplomatic response that would neither insult the Slovenes, nor upset the Yugoslav federal authorities. When Rupel invited the EC Ambassadors to attend the formal celebrations of Slovenia's independence on June 26, it was decided that Ambassador Fietelaars could not take part. Fietelaars wrote a draft reply, which read: 'Professional considerations will make my presence at the ceremony impossible.' On June 24 The Hague approved this draft. In response to further questions from the Embassy in Belgrade, the Ministry responded that there was a possibility that the Netherlands would not recognise Slovenia and Croatia. The Embassy officials could normally visit the areas but would have to avoid creating the impression of implicit recognition. There should for the time being be no official contacts at ambassadorial level but one had to be careful not to insult the Slovenes and Croats unnecessarily. The honorary consuls in Zagreb and Ljubljana would continue to report to the Embassy in Belgrade. 


\section{External Constraints}

The refusal by Van den Broek to heed his officials' calls for a more creative approach at an early stage to the growing crisis must be understood within the framework of the CSCE, EPC and NATO regimes in which the Netherlands operated. The CSCE, EPC and NATO each exercised semiautonomous external constraints that were so strong that the Netherlands would under any circumstances have found it difficult to formulate a different policy from other Western states. The following section traces the external constraints that were exercised by these three mentioned organisations on the Dutch Ministry of Foreign Affairs.

\section{The CSCE}

The principles of the right to self-determination and territorial integrity appear in the Helsinki Final Act of the Conference on Security and Cooperation in Europe (CSCE) of 1975. Initially a consultation process for Western Europe, Central- and Eastern Europe, the Soviet Union, the USA and Canada, it became a permanent organisation in 1995. In the three years of negotiations leading up to the Helsinki Final Act, the Soviets in particular had demanded the inclusion of explicit references to territorial integrity and the inviolability of borders, while Western countries, with a clear interest in promoting democracy, had advocated human rights and stressed the importance of the right to self-determination. ${ }^{34}$

The Helsinki Final Act, which is supposed to be binding in a political but not in a juridical sense, refers to the right to self-determination in its eighth principle. The Final Document of 1989, agreed at the follow-up conference of Vienna, repeated it in paragraph 4. In one important aspect the references to the right to self-determination in the CSCE Act diverge from what had earlier been agreed in the framework of the United Nations, which was the possibility of a peaceful change of borders. This possibility had been included in the CSCE Act's first principle at the insistence of the delegation of the Federal Republic of Germany (West Germany) with a view to keeping open the option of a reunification of the Western and Eastern parts of Germany. ${ }^{35}$ Despite the references to the right to self-determination and the possibility of peaceful border changes, the CSCE Final Act also emphasised the principles of the inviolability of borders' (the third principle) and 'territorial integrity of the states' 
(fourth principle). In addition, given the potential conflict between the principles, the Final Act's eighth principle qualified the freedom to exercise the right to self-determination by stressing that this should take place 'in conformity with... the relevant norms of international law, including those relating to territorial integrity of States. ${ }^{36}$

The impact of the CSCE on Western foreign policy establishments was that of a double-edged sword. As a political institution, the CSCE was too weak to intervene effectively in the Yugoslav crisis, while as a norm-giver it did much to set the parameters of European and American policy. As an institution, the CSCE possessed no credible political or military capacity for the implementation of agreed policies when the Yugoslav crisis blew up. Nor did the CSCE offer procedures or mechanisms for the settlement of disputes within, rather than between, its member states. The Charter of Paris for a new Europe, signed on November 21, 1990, was intended to give the CSCE greater institutional clout and created the CSCE secretariat, the Committee of Senior Officials (CSO), an office of free elections, and the Conflict Prevention Centre (CPC). All three were activated between January and March 1991. Nevertheless, when the Yugoslav crisis descended into war in June 1991, the CSCE was still largely 'a set of voluntary agreements by states to abide by the norms of cooperation, consultation, and human rights that they had established. ${ }^{37}$ Moreover, the USA and the Soviet Union had in November 1990 vetoed CSCE involvement, a decision the US only reversed at the summit of July 1991, when war had already broken out. ${ }^{38}$

While weak as an institution, the CSCE's norms and principles functioned as important parameters for the Western response to the Yugoslav crisis. The efforts by the Netherlands, as well as other countries and organisations, to formulate a credible foreign policy to address the Yugoslav crisis, were greatly hampered by the shared wish to adhere to the conflicting CSCE principles regarding territorial integrity and the inviolability of borders on the one hand and the right to self-determination on the other. These 'diametrically opposed concepts... to an important degree paralysed policy analysis and hampered the ability of the policy makers to adapt to reality. ${ }^{39}$ Van den Broek acknowledged this, saying that 'the tension between these two basic principles was the continuing dilemma that we [the Foreign Ministers] had to cope with'. ${ }^{40}$ 


\section{Europe}

'Obsessed with proving themselves, on the one hand, and preparing the difficult arrangements for their union, on the other, and with only half an eye on the problem itself, the EC was nonetheless in the vanguard of international efforts to deal with the dissolution of Yugoslavia.' ${ }^{41}$ Until May 1991, Yugoslavia was for most member states a problem of secondary importance in comparison with the building of a union. In the light of efforts to build that union, with its common foreign and security policy component, EC consensus became an important interest in itself.

Perhaps one of the first occasions in which a European politician invoked the concepts of unity and territorial integrity in the context of the Yugoslav crisis, was a visit by Luxembourg Foreign Minister Jacques Poos to Yugoslavia on August 27 and 28, 1990. The Luxembourg Foreign Minister was accompanied by the Chargé d'Affaires of the Netherlands Embassy, Dirk Hasselman (see above). During talks with Yugoslavia's rotating federal Presidency (not the government), Poos strongly criticised Serbian oppression in Kosovo, but also stated that the EC wanted Yugoslavia as a 'strong federal state and had no interest whatsoever in a break-up of the country.'

In October 1990, Yugoslavia was mentioned in two declarations by the EC Foreign Ministers. At the General Affairs Council in Luxembourg on October 22 the Ministers instructed the committee of political directors to 'make recommendations with regard to the appropriate means to encourage the maintenance of its unity in a framework of democracy.' Six days later, the EC Foreign Ministers, meeting in Rome, expressed their 'wish that the present process of democratic evolution in Yugoslavia will succeed in the framework of a development of respect for human rights and the preservation of the unity and the territorial integrity of that country.'42

While an important decision, in Rome there had been no discussion of the question of why territorial integrity should become a cornerstone of the EC's approach to Yugoslavia. The meeting in Rome had focused entirely on the process of European integration and the preparations for the upcoming Intergovernmental Conference on European Union, to be held the next year in Maastricht, in the Netherlands. According to Van 
Walsum, the Italian-drafted statement stressing the importance of Yugoslavia's unity and territorial integrity 'was not discussed at all by the Ministers; it lay there suddenly and then they all simply concurred.' ${ }^{43}$

The committee of political directors met on November 14 and 15, 1990 to draw up a response to the ministerial request for advice on how the territorial integrity of Yugoslavia could best be supported. The German Political Director had difficulty with the draft under discussion, which emphasised the principle of territorial integrity. His argument, the one that so impressed the Dutch Eastern Europe Division, was that if the choice between stability and the unity of Yugoslavia, on the one hand, and democracy and human rights, on the other, became inevitable, priority would have to be given to the latter. The German argument, later used by Van Walsum in his discussions with US officials, was brushed aside and the political committee concluded that the political imperative, formulated by the Foreign Ministers, of supporting Yugoslavia's territorial integrity must have priority.

This was a first indication that unease existed within the European Community about the policy to which the Ministers had signed up in October 1990. Another series of internal discussions in January and February 1991 revealed that the potential for division was real. The first of these meetings took place on January 29 in Belgrade. There, the EC Ambassadors had difficulty agreeing a draft declaration, to be adopted the following week by the political directors and the Foreign Ministers. Whereas the Greek and French Ambassadors took up positions favouring the continued EC support for Yugoslavia's territorial integrity, the Ambassadors eventually decided to go so far as to omit any reference to the EC's earlier stated interest in Yugoslavia's continued unity and territorial integrity. However, when the political directors met on February 4, 1991, the principle of territorial integrity was reintroduced, following a reminder by a representative of the European Commission that the ministerial declaration of December 18, 1990 had contained a reference to unity and territorial integrity.

On March 4, the political directors, who had gathered to discuss US initiatives, again papered over the unease about existing policy by agreeing to stick with it nonetheless. Several political directors said that in their separate discussions with Dobbins in EC capitals they had pointed out to 
him that public opinion in their country would not allow a Slovenia that had declared independence to 'remain completely in the cold'. Nevertheless, the political directors agreed that support for territorial integrity should remain EC policy on the basis of the following argument:

in those cases where the pros and cons of maintaining the territorial integrity of a state threatened with disintegration were approximately balanced, respect for territorial integrity should come first. There was agreement that a very dangerous situation would arise in central and Eastern Europe if politicians, confronted with ethnic problems, would begin to see the creation of a new state as an easy way out.

The EC Foreign Ministers, who also met on March 4, briefly discussed Yugoslavia during lunch, repeated their call for a dialogue between Belgrade and the republics. Five days later, however, Serbian security forces backed up by tanks crushed student demonstrations in Belgrade. ${ }^{44}$ The event prompted Germany to circulate a tough draft-declaration, which spoke of the need for a 'creation of a new Yugoslavia'. Other member states argued that Germany was racing ahead of developments and it proved impossible to reach agreement.

The political directors decided to suspend the issuing of a declaration pending further developments in Yugoslavia. The Eastern Europe working group was asked to advise on the matter whereby it was to pay specific attention to the problems involved in the attempts to issue a balanced declaration which would do right to the tension that existed between the principles of unity of the central state on the one hand and the right to self-determination on the other.' Given the struggle for independence of individual Yugoslav republics as well as former Soviet republics, notably the Baltic States and Ukraine, the working group was asked to advise on the question of to what extent the unity of Central European states should be supported under all circumstances.

The apparent mood shift seemed to provide an opening for Van Walsum and the Eastern Europe Division to articulate their concerns about the continued support for the territorial integrity of Yugoslavia. In a discussion paper distributed before the meeting, the Netherlands argued: 'there seems to be a tendency among the Twelve to prefer the preservation of the 
unity of states (e.g. Yugoslavia) to disintegration as a result of secession.' Noting that the fourth principle of the Helsinki Final Act forbade countries to take any action to undermine each other's territorial integrity but did not oblige them to support each other in preserving their territorial integrity, the Dutch posed the question of whether 'contacts' with, or even 'recognition' of a secessionist republic should be seen as such an 'action'.

When the Eastern Europe working group met, on March 19 and 20, it seemed initially that there was considerable support for the Dutch (and German and, probably, Danish) line of thought. The working group concluded that for the Soviet Union as well as for Yugoslavia, a 'double track policy' was needed whereby the EC would maintain contacts, both with the central authorities and, independently, with the republics. However, this conclusion was thought to contradict the established policy of maintaining a formal distinction between the central authorities and the independent Yugoslav republics. As a result, the working group's meeting ended in confusion. The report of the meeting, drafted and circulated by the EPC secretariat, qualified the conclusions: the contacts should primarily serve to convince the Yugoslavs to stay together.

In May, developments in Yugoslavia finally turned the crisis into an acute political problem for the European Community's Foreign Ministers. In a clash in the Serb-held village of Borovo Selo in Croatia, Serb militiamen killed twelve Croatian policemen, while three Serbs also lost their lives. ${ }^{45}$ Further complicating the situation was the announcement on 15 May by Serbia that it would block the rotation of the Yugoslav federal Presidency to the Croat Stipe Mesic.

As had been the case with the violent suppression of the student demonstration in Belgrade, Germany wanted the EC to issue an unequivocal and strong response to the Borovo Selo incident. A German draft declaration no longer mentioned the words 'unity' and 'territorial integrity' and concluded that the fundamentals of a durable solution were democracy, right to self-determination, respect for human rights and the rights of minorities as well as the rule of law. The subsequent discussions revealed that the majority of EC member states still believed that Yugoslavia's territorial integrity should remain the key principle of EC policy. In the final declaration, again, German thinking was left out and the 'unity' of Yugoslavia again advocated. 
The shared wish to stick to a consensus that had been reached in late 1990 continued to paralyse the European Community until the Slovenian and Croatian declarations of independence of June 25, 1991 forced the Europeans to face up to a new reality. The first occasion on which to reassess the European Community's policy of support for the territorial integrity of Yugoslavia came with the European Council of June 28 and 29 in Luxembourg. The declarations of independence now constituted a fact and armed conflict between Slovenian police and the Yugoslav Army had erupted the day before. A worst-case scenario that took into account such developments had not been worked out. The Eastern Europe working group and the CoPo had decided that a wrong signal would go out to Slovenia and Croatia if the EC worked out potential responses to a crisis situation triggered by their coming declarations of independence. Instead, it had been decided to adopt a 'wait and see' attitude. Existing policy would have to be continued right up until the moment of actual secession and there would be no recognition before all possible consequences for peace and security had been evaluated. There were to be no deals with Slovenia that could not be reproduced with other republics, so as to keep alive the possibility of a confederation. No wonder that the European Council 'had difficulty with the new situation', as Prime Minister Ruud Lubbers put it. According to Lubbers the main question faced by the European Council was: 'How was one to handle the right to self-determination within Yugoslavia?'.46 This was the question the EC Foreign Ministers had found impossible to address seriously without splitting the European Community. Not surprisingly the European Council did not, within the space of two days, manage to find satisfying answers either. Van den Broek remembers a 'vehement debate about CSCE principles' between French President François Mitterrand and German Chancellor Helmut Kohl. 'Mitterrand emphasised the importance of territorial integrity and Kohl that of the right to self-determination. ${ }^{37}$ Indeed, in his remarks to the press, Mitterrand said that the EC 'must not be accused of trivialising the territorial integrity of Yugoslavia', while Kohl declared 'that the priorities now were human rights, the rights of minorities and the right to selfdetermination' [of individual Yugoslav republics]. ${ }^{48}$ As some sort of conclusion, according to Lubbers, the European Council agreed that to 'keep Yugoslavia together as a country seemed neither a realistic nor a desirable option. Nor was an uncontrolled departure by the constituent republics. The process instead had to be managed and behind that aim the European Community would rally in unison and with all strength. ${ }^{49}$ 
The European Council decided to dispatch the ministerial Troika to Yugoslavia with the aim of negotiating a cease-fire. The Troika presented three demands: a resolution of the constitutional crisis; a suspension of three months of the implementation of the declarations of independence; and the return of the Yugoslav army to its barracks..$^{50}$ On June 28 Foreign Ministers Poos, Van den Broek and Italian Foreign Minister Gianni de Michelis boarded a plane, accompanied by dozens of journalists. In a series of tumultuous meetings in Belgrade and Zagreb, the Troika Ministers posed their demands. Believing that the various Yugoslav parties had accepted all three, the Troika flew back to Luxembourg in the middle of the night so as to be able to report to the European Council on the morning of June 29. On his way to the meeting, Van den Broek told the assembled journalists: 'I believe there are signs of hope, but these days will have to show whether the promises are being lived up to. ${ }^{51}$ They were not: twenty-four hours later, the same three Ministers were on their way back to Belgrade to put the same demands to the same parties. De Michelis, whose place in the Troika was about to be taken up by his Portuguese colleague, had insisted that he should take part in the Troika one more time.

\section{The United States}

Initially, the USA was more active in trying to formulate a response to the Yugoslav crisis than the EC. US analysis showed that a break-up of Yugoslavia would be accompanied by violence (see above). Given that the US saw a disturbing analogy between events in Yugoslavia and developments in the Soviet Union, the USA initially strongly urged the Europeans to join it in finding a way to prevent a violent break-up of Yugoslavia. However, like the European Community, the US too became caught between the principles of territorial integrity and the right to self-determination.

In February 1991, the Europeans were asked to 'develop new ideas, which could contribute to preventing disastrous developments in Yugoslavia.' In a conversation on 14 February between Dutch officials and US Deputy Assistant Secretary Curtis Kamman in Washington, the latter confirmed that the US wanted to prevent Yugoslavia from falling apart because this would lead to chaos, civil war and problems for all neighbouring countries. In Washington's view the best solution would be a 'flexible confederation or a so-called asymmetrical federation.' Dobbins repeated the same message during his European tour at the end of the month (see above). 
US policy, like that of the EC, was little more than wishful thinking along the following lines: because we support the territorial integrity of Yugoslavia, we oppose moves towards secession even if we have no clear idea on how we can stop it, nor on how the right to self-determination can be given meaning within a Serb-dominated Yugoslavia. Nevertheless, because this approach was US policy, it was the one to stick to for most of the EC member states and NATO partners as well. Thus, when in March 1991 President George Bush sent a letter to Yugoslav Prime Minister Markovic to emphasise once more the importance of Yugoslavia's territorial integrity, US officials pointed out that it would be good for a forthcoming EC ministerial declaration to match the content of Bush's letter, which had stated that the US would would neither encourage, nor reward those who would break the country apart. The declaration eventually adopted by the EC Foreign Ministers on March 26 was handed to the Yugoslav federal authorities 'in close concert with the USA' by the Troika of EC Ambassadors. The declaration concluded that 'a united and democratic Yugoslavia stands the best chance to integrate itself harmoniously in the new Europe.'

US policy was kept up until well after the declarations of independence by Slovenia and Croatia (see chapter three). A telling moment constituted a visit by Secretary of State Baker to Belgrade on the eve of the Slovenian and Croatian declarations of independence. Following the CSCE summit in Berlin on June 19 and 20, where Baker had according to the Croatian member of the Yugoslav Presidency 'brushed aside' Croatian efforts 'to obtain support for the peaceful disassociation of the country', Baker went to Belgrade and spoke to eleven Yugoslav leaders in one day. ${ }^{52}$ As he later indicated, he came out of the talks more concerned than upon his arrival. He had tried to convince the Slovenes not to declare independence unilaterally and had warned them that neither the US nor any other country would recognise a unilateral secession. At the same time, indicating the dilemma, Baker had warned the Serbs not to use force to impose their will on the Slovenes and Croats. If Serbia were to force the US 'to choose between unity and democracy', the US would 'always choose democracy. ${ }^{53}$ Despite Baker's stern words, there were, as Fietelaars reported, 'very few indications that the Yugoslav leaders were prepared for sensible negotiation and compromise.' 
Thus ended the fruitless attempts by the international community to prevent the disintegration of Yugoslavia. In the following days, the crisis descended into war. On July 1 the Netherlands took on the EC Presidency whereby its role changed considerably. Apart from the position of the Netherlands, the international external environment itself also changed in two important respects. While the EC member states began to lose their appetite for consensus per se, the USA disengaged from the issue altogether.

\section{Conclusion}

This chapter has traced the failure of the Dutch Foreign Ministry to formulate a credible foreign policy regarding the Yugoslav crisis between July 1990 and June 1991. It has been argued that the absence of a credible policy was not due to an intelligence failure. Yugoslavia's troubles did not go unnoticed. Between July 1990 and May 1991, the Embassy in Belgrade and the Eastern Europe Division in The Hague issued regular warnings that Yugoslavia might, even would, disintegrate. In addition, the Eastern Europe Division, later supported by the Director-General for Political Affairs, offered a starting point for policy, namely to give primacy to the principle of the right to self-determination over the principle of territorial integrity. Whether or not one agreed with this choice, it was important that it had been outlined.

However, the response to the warnings was inadequate, due primarily to a set of political priorities on the part of the Dutch government, in turn largely the result of institutional constraints imposed on the Dutch foreign policy machinery by international regimes. The episode had highlighted that for a smaller state like the Netherlands membership of and loyalty to regimes does not only bring the benefit of a relatively great influence within and through such a regime but can also limit considerably the individual state's manouvering freedom. This is all the more true in a country where the foreign policy élite had not deemed it necessary for decades to think critically about specifically Dutch interests and preferences. With regard to the Yugoslav crisis, it seemed unnecessary, even risky, for a medium-sized NATO ally, EC partner and champion of international law to promote an approach that could not a priori count on the support of the leading elements in these regimes, in spite of the belief held by several important individual participants to the Dutch foreign 
policy process that a managed disintegration of the Yugoslav federation would be a more effective approach than the continued focus on the country's territorial integrity.

Conflicting CSCE principles posed EC Foreign Ministers with a dilemma, which they 'solved' in their declarations in late 1990 by turning the principle of territorial integrity into the cornerstone of EC policy. As the Yugoslav crisis deepened, these public statements, in combination with the widely shared desire for the EC to project unity, ensured that the principle of territorial integrity remained at the centre of EC policy until June 1991. Former Dutch Foreign Minister Hans van den Broek admits that it was not until late June that the EC governments started 'thinking about how one could stop the violence in its tracks and how one could let the fragmentation take place in as orderly a fashion as possible. ${ }^{34}$

If even Germany, with its greater political clout and with stronger views on the issue, was unable to steer EC policy in a different course, it is hard to imagine how the Netherlands could have achieved this goal. This was all the more the case in a situation where support for Yugoslavia's territorial integrity was not just a European consensus but a Euro-American consensus as well. The USA had been the strongest of all advocates of Yugoslavia's territorial integrity. Given the long-established Dutch interest in maintaining NATO's cohesion and US leadership in European security affairs, US policy by itself might have prevented the Netherlands from going along - at the political level - with any change of course that might have occurred within the EC.

The existence of these external constraints, however, does not excuse the absence of an independent Dutch view on the Yugoslav crisis. The criticism from the Dutch regional experts that their superiors were not interested in the Yugoslav crisis seems justified, given that no serious attempt to formulate policy seems to have taken place. No internal policy debate seems to have taken place within the Foreign Ministry following which participants might still admittedly have been forced to accept that good options were unavailable, nor did Van den Broek ever seem interested in alternative policy options. It seems that until May 1991, when a constitutional crisis occurred in Yugoslavia, the Yugoslav crisis could not compete with other foreign policy issues for the attention of the Minister. Symbolising the feeling that the Yugoslav crisis came at a time when officials were 
already hard-pressed by other issues was a remark scribbled onto one of Fietelaars' florid reports from Belgrade, in March 1991: 'This reporting is, like previous reports, interesting but much too long (certainly when put next to the other reports from Belgrade).'

\section{NOTES}

1 Quoted in: Woodward, Broken Bonds, p. 120.

2 Marten van Heuven, 'Yugoslavia: What Issues? What Policies?' Remarks to the Washington Institute of Foreign Affairs, The Cosmos Club, Washington, D.C., February 4, 1993, RAND/P-7808, February 1993, p. 2.; David Binder, 'Yugoslavia seen breaking up soon. C.I.A. paper predicts action in 18 months and adds civil war is likely', New York Times, 28 November 1990.

3 Gow, Triumph, p. 26; Meier, Wie Jugoslawien verspielt wurde, p. 383.

4 Meier, p. 383.

5 Interview Ambassador Jan Fietelaars, Rosmalen 25 August 1995.

6 Ibid.

7 Ibid..

8 Cf. Ellen Berends, 'De desintegratie van de Sovjetunie en de verantwoordelijkheid van het Westen' (The disintegration of the Soviet Union and the responsibility of the West), Internationale Spectator, Vol. xlv, No. 7, July 1990.

9 Interview Ellen Berends, The Hague, 20 January 1997.

10 Interview Harm Hazewinkel, The Hague, 5 January 1995.

11 Quoted in: Twan Huys, In opdracht van Hare Majesteit. Diplomaat in crisistijd (In Her Majesty's service. Diplomat in a time of crisis) (Weert: M\&P, 1994), p. 117.

12 David Gompert, 'How to Defeat Serbia', Foreign Affairs, Vo. 7,3 No.4, July-August 1994, p. 32. Gompert was Senior Director for Europe and Eurasia on the Bush Administration's National Security Council staff.

13 This number was raised to four when the Netherlands took on the EC Presidency on July 1, 1991.

14 Interview Hazewinkel.

15 Interview Herman Schaper, Brussels, October 13, 1997.

16 Ibid.

17 Ibid.

18 Ibid.

19 Interview Peter van Walsum, The Hague, August 20, 1995. 
20 Ibid.

21 Ibid.

22 Ibid.

23 Interviews Hazewinkel and Van Walsum.

24 Interview Hazewinkel.

25 Ibid.

26 Interview Van Walsum.

27 Ibid.

28 Interview Hans van den Broek, Brussels, October 13, 1997: Meier, p. 383.

29 Ibid.

30 Ibid.

31 Cf. Hans van den Broek, 'Internationale betrekkingen: wetenschap en beleid' (International relations: science and policy), Internationale Spectator, Vol. Xliii, No. 1, January 1989, pp. 40-43; Hans van den Broek, 'Nederlandse betrokkenheid bij het vormgeven van een nieuw Europa' (Dutch involvement in the shaping of a new Europe), Internationale Spectator, Vol. Xliv, No. 8, August 1990, pp. 449-456.

32 Baker, The Politics of Diplomacy, pp. 89-90, 95, 618, 639.

33 On Austrian policy, see: Woodward, Balkan Tragedy, pp. 148-149, 160,162, 164.

34 Berends en Hazewinkel, 'Nederland en Oost-Europa', Internationale Spectator, 1992, p. 72.

35 Felix Ermacora, 'Rights of Minorities and Self-Determination in the Framework of the CSCE', in: Arie Bloed en P. van Dijk, eds., The Human Dimension of the Helsinki Process (Dordrecht: Kluwer, 1991), pp. 197-206; Harm J. Hazewinkel, 'Zelfbeschikkingsrecht en territoriale integriteit,' (The right to self-determination and territorial integrity), Internationale Spectator, Vol. XLIX, No. 6, pp. 333337.

36 Conference on Security and Cooperation in Europe, Final Act, Helsinki 1975.

37 Woodward, Balkan Tragedy, p. 175.

38 Ibid., p. 155.

39 Tom Quiggin, 'Srebrenica en de internationale gemeenschap in Bosnië. Een samengebalde chaos?' (Srebrenica and the international community in Bosnia. A clenched chaos?', Internationale Spectator, Vol. lii, No. 2, February 1998, p. 80.

40 Interview Van den Broek.

41 Gow, Triumph, p. 30.

42 Conclusions of the EC Presidency (Italy), regarding the European Council in Rome, October 28- 29, 1990.

43 Interview Van Walsum.

44 Silber and Little, The Death of Yugoslavia, pp. 119-126. 
45 Ibid., pp. 140-143.

46 Ruud Lubbers, “'Drie keer” voordat de haan kraait' ('Three times' before cockcrow), Internationale Spectator, Vol. 1, No. 7/8, July/August 1996, p. 369.

47 Interview Van den Broek.

48 The Independent, 1 July 1991.

49 Lubbers, Internationale Spectator, July/August 1996, p. 369.

50 Gow, Triumph, p. 51.

51 Rob Meines, "Als we niets doen, weten zeker dat het moorden doorgaat"; Rol EG bij de Balkancrisis begon zo mooi' ('If we do nothing we are certain that the killing will continue' EC role in the Balkan crisis began so nicely), NRC Handelsblad, September 7, 1992.

52 Quoted in: Lenard Cohen, Broken Bonds. Yugoslavia's Disintegration and Balkan Politics in Transition, 2nd edn. (Boulder: Westview Press, 1995), p. 220.

53 Baker, p. 482.

54 Interview Van den Broek. 


\section{From 'Even-Handedness' to 'Selectiveness', July - December 1991}

The Yugoslav crisis was escalating into armed conflict. TV images of skirmishes in Slovenia in late June 1991 brought home to European and American families the incredible message that war had returned to Europe. In Slovenia hostilities ended quickly, due to the combination of an effective defence on the part of the Slovenes and the absence of a Serb minority question. Croatia was not so lucky. Fierce fighting erupted there, which lasted until the end of the year. By the end of 1991, the combined Serb/Yugoslav forces controlled large swaths of territory in the Croatian border areas. The vicious siege of Vukovar, which fell to Serb units in November 1991, and in particular the attacks by Montenegrin units of the Yugoslav People's Army on the tourist town of Dubrovnik, aroused Western public opinion. Innocent people had been murdered in cold blood on both sides, but the mass murder by Serb forces of Croat patients from the hospital in Vukovar counted as a horrendous crime against humanity.

As holder of the EC Presidency, the Netherlands was in a position of responsibility and influence at an important moment in European history. This position of prominence in the EC might have meant little, had it not been for the fact that the EC itself continued to be in the driver's seat of international Yugoslavia-diplomacy, given the absence of the United States from the scene. The responsibilities associated with the EC Presidency forced Dutch policy makers to operate with more maturity than they had done before and would do later. Moreover, as the stakes began to rise, the Yugoslav crisis became a priority issue for Foreign Minister Hans 
van den Broek, who according to one of his Cabinet colleagues kept the Yugoslavia-issue 'rather close to his chest'.

Dutch policy during the second half of 1991 constituted a broad movement from 'even-handedness' to 'selectiveness'. The initial approach was 'even-handed' to all the Yugoslav parties. Increasingly, 'even-handedness' was seen as an ineffective way to contain the strongest and most aggressive party to the conflict, Serbia. As a result, this approach gave way to one that was 'selective' and directed primarily against Serbia and the Yugoslav army. This is not to suggest that the development from evenhandedness to selectiveness was a smooth one. 'Selective' proposals were made when the trend favoured 'even-handedness' and vice versa. The selective approach carried a risk that the Netherlands would drift apart from the gravity of opinion in the EC and NATO, which still centered around 'even-handedness'. However, Dutch Yugoslavia policy was kept firmly in check, not only through the external constraints associated with regime membership, but by three clearly defined Dutch institutional interests.

The most important institutional interest for the Netherlands was the cohesion of the EC, particularly at a time when the EC member states were busily preparing a treaty for a European Political Union. According to Herman Schaper: 'We considered it a disaster if the camps in the EC would fall apart. The primacy of our policy was to keep the Twelve in line at all cost. Minister Van den Broek categorically did not want polarisation between the Twelve to occur as a consequence of Yugoslavia.' ${ }^{2}$ A second interest, closely related to the first, was the interest in a Presidency that would be termed successful afterwards. While 'success' was initially defined as a negotiated settlement, as the pressure increased and the criticisms of EC policy became more marked, the precise nature of the outcome mattered less and less, so long as it allowed the EC to portray some measure of unity and it was reached under Dutch chairmanship. A third important institutional interest was the continued leadership of NATO and the United States in European security affairs. 


\section{Even-Handedness: July - October 1991}

Europe and the USA continued to support Yugoslavia's territorial integrity up to the moment of secession and beyond. Despite what now had become public opposition by Germany, this policy persisted during the first week in July 1991. Minister of Foreign Affairs Hans van den Broek, in particular, showed himself to be a strong advocate of maintaining existing policy. An explanation for Van den Broek's attitude would be that, first, the Dutch Foreign Ministry had not yet developed a real view of the causes and consequences of the Yugoslav crisis. In the absence of credible policy alternatives, it seemed safest to continue a policy that had, after all, been agreed to by all EC member states. Secondly, the United States government remained adamant that nothing should be done to encourage the secessionists and that the goal remained the preservation of some kind of Yugoslav federation.

The first occasion, since the beginning of the Dutch Presidency, on which Van den Broek reconfirmed the EC's support for Yugoslavia's unity, was a renewed mediation attempt by the EC Troika of Foreign Ministers in Belgrade and Zagreb on June 30 and July 1 . This was the second time in twenty-four hours that the EC Troika tried to arrange the rotation of the Yugoslav Presidency, as well as a suspension of the Slovenian and Croatian declarations of independence and a return to the barracks by the Yugoslav army. When the clock struck midnight in Belgrade, Luxembourg Foreign Ministers Jacques Poos and Van den Broek stood up, toasted with President Milosevic and turned towards the assembled Yugoslav Presidency members. Van den Broek told them: 'You see, this is how democracy works. I will chair the meeting now because I have taken over [the EC Presidency]. Similarly, you should elect Mesic'. In return he promised: ' ... and I will make a public statement saying that Europe supports the unity of Yugoslavia. ${ }^{3}$ Later on July 1, the new Dutch EC Presidency distributed a strongly worded telegram to all EC capitals, in which the Netherlands stated that the Twelve should do all in their power to prevent the break-up of Yugoslavia.

Van den Broek and Van Walsum flew to Washington on July 2 in an attempt to involve the Bush administration more directly in the management of the Yugoslav crisis. In Washington they met with National Security Adviser Brent Scowcroft and Secretary of State James Baker, who 
made it clear that the administration still believed in the importance of keeping the Yugoslav federation together as a country. According to Van Walsum, the visit was a 'waste of time'. Van Walsum had become ever more pessimistic regarding the possibility of keeping Yugoslavia together and felt the Americans were refusing to face up to reality: 'There was a complete absence of vision and commitment. There was no willingness to talk about any option other than the territorial integrity of Yugoslavia.'

The effect of this visit on the Dutch Presidency was twofold. While it confirmed that the line followed so far was indeed the line supported by the leading NATO ally, the United States, it also became clear that the United States did not want to invest much in order to make its policy actually work. This meant that at the beginning of the term of the Dutch Presidency, its position and those of other member states who supported existing policy weakened considerably in relation to those, in particular Germany and Denmark, who favoured an early recognition of Croatia and Slovenia. It would not be possible for traditional NATO allies like the Netherlands to fall back on the US position as a legitimisation of their own stance. Given the US aloofness, Van den Broek was forced to give less consideration to American opinion and policy than he would normally have wished to. ${ }^{5}$

Van den Broek and Van Walsum flew back to The Hague during the night of July 3, just in time for the first of what proved to be a long series of EC ministerial meetings devoted to the Yugoslav crisis. Throughout this ministerial meeting and the subsequent press interviews, it emerged that the tension between the German position on the one hand, and the French, British and Dutch positions on the other, had only grown and threatened to become a major embarrassment for the $\mathrm{EC}$ as a whole. At the meeting, Germany proposed to abandon the policy of supporting Yugoslavia's unity. Instead, argued Foreign Minister Hans-Dietrich Genscher, the EC member states should threaten Serbia 'with immediate recognition of the independence of Slovenia and Croatia if the JNA [Yugoslav People's Army] renews its intervention.' According to a Dutch report, the German proposal had been supported by Denmark and Italy (and to a lesser extent Luxembourg and Belgium) but opposed by the remaining member states. Sensing that a majority opposed the German proposal, the Dutch EC Presidency had sided with that majority and successfully resisted the explicit language requested by Germany. In remarks to the press Van den 
Broek made no secret of his opposition to the German proposal. Asked about his opinion regarding recognition, Van den Broek answered: 'I don't find that an effective approach. The reverse, I feel it could exacerbate the tension and the violence.' ${ }^{\prime}$

\section{Negotiating a General Settlement}

With the Dutch EC Presidency in a central role, the international attempt to preserve the Socialist Federative Republic of Yugoslavia was finally abandoned on the island of Brioni on July 7. Apart from German pressure and American aloofness, it was Van den Broek's own confrontation with reality, which caused this shift in the stance of the EC Presidency. Meier is, therefore, mistaken to argue that the negotiations conducted on the island of Brioni under the chairmanship of Van den Broek were still meant to 'restore' the old Yugoslavia.' Rather, with regard to a major element of the Brioni agreement, EC-chaired negotiations between the Yugoslav parties, a Dutch report commented: 'the idea that these negotiations could lead to the total independence of Slovenia seems at present to have been accepted by everyone.'

The declaration of Brioni was generally seen as a diplomatic success. On Brioni, after thirteen hours of negotiations, a 'domineering' Van den Broek, as Silber and Little put it, could announce a 'joint declaration', in which the parties agreed to the three demands which the EC had formulated at the end of June. There would be a three-month moratorium on the implementation of the Slovenian and Croatian declarations of independence, though the declarations themselves still stood. The Brioni agreement also stipulated that 'a new situation' had arisen and that negotiations for a peaceful solution to the conflict would start no later than August 1 and 'were to include all aspects of Yugoslavia's future, without preconditions.' An EC Monitoring Mission (ECMM) would be deployed in order to oversee the cease-fire in Slovenia. Crucially, the Brioni declaration gave the EC member states the opportunity to adapt to the new situation and agree a new policy, even though the agreement was 'fragile' and the 'prospects for constructive negotiations still extremely uncertain'.

The main weaknesses inherent in the Brioni declaration were, first an underestimation of the potential for violent conflict in Croatia and Bosnia-Herzegovina, and, second, the mistaken assumption that the EC 
possessed the will and the capacity to follow up on the declaration by agreeing a new approach and then pursuing it in unison. As Van den Broek himself recalled, the Brioni declaration 'gave us time... but I remember that Tudjman approached me and said: "Mr. Van den Broek, congratulations, but beware: this was Slovenia, but the next one is Croatia."”

The Slovenian question was much more easily solved than the Croatian case, partly because it was less complicated and partly because it triggered fewer emotions among West European politicians. As Silber and Little explain, the Slovenes and Serbs themselves shared no major bones of contention, given that there was no large ethnic Serb minority living in Slovenia, and reached an informal agreement on Slovenian secession in Brioni. ${ }^{10}$ In Croatia, by contrast, Serbs made up some 11 per cent of the population. Whereas Croatia was adamant that there could be no change of its borders, the Serbian minority was equally adamant in their refusal to become part of a new Croatian state. In 1991, West European politicians and diplomats looked at Croatia with no or hardly any more sympathy than they reserved for the Serbs. The Dutch in particular were influenced by the legacy of the Second World War, during which Nazi Germany had occupied the Netherlands for five years and murdered most of its Jewish population. For decades after the war, anti-German feelings had run deep among the Dutch. The fascist Croatian Ustasha regime had been a staunch ally of Nazi Germany and had methodically murdered hundreds of thousands of its Serb, Gypsy and Jewish inhabitants. In combination with the fact that Croatia had a substantial Serb minority, the legacy of the Second World War influenced people's ideas about what constituted a fair approach to the Serb-Croat conflict. In addition, there was at this early stage in July a real concern, perhaps a greater one than at any later stage during the Dutch Presidency, about Croatian attitudes towards the multi-ethnic republic of Bosnia-Herzegovina. Reports from the Embassy in Belgrade made clear that the Croats, despite their conflict with the Serbs, were negotiating with the latter with an eye to dividing up Bosnia-Herzegovina at the expense of that republic's Muslim population. ${ }^{11}$ From the Dutch point of view, Croats and Serbs were equally bad. Hence, the communis opinio inside the Dutch Foreign Ministry at this stage was that for any solution to be both effective and fair, it would have to be even-handed. 
Brioni perhaps created the breathing space the EC needed, but the member states proved unable to formulate a credible follow-up. Nevertheless, a first attempt to formulate a common policy was undertaken by the Dutch EC Presidency. The EC Foreign Ministers gathered on July 10 to discuss the results of Brioni and agreed that it was now necessary to identify ways in which the EC could assist the Yugoslav parties to solve their problems. The Dutch believed that if the EC was to meet the expectations surrounding its mediating role and to have real influence on the negotiations, its member states would have to rally behind a common approach. In the week following Brioni, Van Walsum sat down to study the conflict and formulate a first, tentative attempt to structure the intra-EC debate on Yugoslavia.

Between July 8 and 12, Van Walsum immersed himself in 'nothing but Yugoslavia.' ${ }^{12}$ His conclusion was that the 'real choice was between the recognition of individual republics within their existing borders whereby the protection of minorities would have to be guaranteed by legal instruments, or the redrawing of the republics' borders in order to achieve a maximum degree of ethnic homogeneity. ${ }^{13}$ By July 12, Van Walsum had worked out both options in a memorandum, which he sent to Van den Broek, who was then in the regular Friday meeting of the Cabinet. According to Van Walsum, Van den Broek telephoned him that afternoon to say that, while an interesting academic analysis, the paper did not actually constitute policy. For his paper to be policy, Van Walsum would have to make a case for one of the two options. Van Walsum told Van den Broek over the phone that, despite obvious objections against border changes, this was nonetheless the option he favoured. According to Van Walsum, the Foreign Minister replied that once the author's preference was reflected in the paper, it could go out to the EC capitals as a Coreu telegram' (Coreu stands for 'Correspondence Europeenne', the telegram system through which the EU capitals communicate). ${ }^{14}$ This telegram was sent on Saturday July 13, with only the initials of the Director-General for Political Affairs on it. The key section of the proposal was a carefully worded case in favour of a 'voluntary redrawing of internal borders as a possible solution.' ${ }^{15}$

As was pointed out, Van Walsum did not believe that legal instruments could solve Yugoslavia's minority problems. 'It was unthinkable that the Serbs in the Krajina, for example, would reconcile themselves to an 
independent Croatia on the basis of a minority statute.' 16 'If Yugoslavia was being destroyed by its ethnic differences, it did not seem very sensible to choose precisely that option which would result in the creation of new independent states (most notably Bosnia-Herzegovina), that would be plagued by exactly the same ethnic differences. ${ }^{37}$ Moreover, Van Walsum believed the means to stop the moves towards partition from the outside were lacking. Crucially, while Van Walsum recognised that the Serbs stood to gain most from a revision of borders, the proposal was applicable to all of Yugoslavia, including Kosovo, where the ethnic Albanian population had similar ambitions to the Croats and Slovenes, Bosnians and Serbs. As such, the proposal was intended to function both as a carrot and a stick in the EC's relationship with the Serbian leadership.

The Dutch border changes proposal was rejected out of hand by virtually all the EC partners (only Denmark expressed some sympathy). It clashed with the German approach, as presented by the acknowledged Yugoslavia-expert at the German Ministry of Foreign Affairs, Michael Libal, which was founded precisely on recognition of the republics within their existing borders as the juridical instrument to render illegal the Yugoslav army's intervention in Croatia. ${ }^{18}$ In addition, even those countries which disagreed with Germany's calls for a speedy recognition were adamant that if the territorial integrity of Yugoslavia could not be preserved, then sovereignty should be transferred to the republics within their existing borders. This was perceived to be particularly important in the light of the growing unrest in the Soviet Union, where the internal borders, as in Yugoslavia, did not necessarily correspond to ethnicity. Moreover, it was argued by a number of member states that the Dutch proposal would open up a 'Pandora's box', since borders were imperfect nearly everywhere in the world, in particular in the Soviet Union and Africa.

During the next week, it turned out that even within his own Ministry, Van Walsum stood completely isolated. His deputy, Christiaan Kröner, sharply criticised the proposal, while Van den Broek, embarrassed by the overwhelmingly negative response, did not push it. Six years after the event, Van den Broek could not remember that he had given his consent for the text drafted by Van Walsum to go out as an official proposal: 'I do not, in any case, claim the fatherhood of the border changes proposal by Van Walsum. I can actually not remember it and, given my views at the time, I do not understand how I could have supported such a proposal.'19 
The possibility of border changes was firmly buried by the EC Foreign Ministers at a meeting in Brussels on July 29 -attended by Van den Broek and Kröner, who accompanied the Minister in Van Walsum's absence. The Ministers declared that a forceful change of Yugoslavia's internal borders could not be a solution to the crisis. Although this did leave open the theoretical possibility of peaceful and mutually agreed changes of borders, the Ministers had implicitly upgraded Yugoslavia's internal borders to the level of international borders. The Dutch Presidency's first attempt to formulate a common approach for the EC had failed.

\section{The First Move towards Selectiveness: the Anti-Serbian Declaration of August 28}

The rejection of the border changes proposal had a substantial impact on the Dutch approach to the Yugoslav conflict. In particular it facilitated the shaping of a consensus in favour of some form of military intervention. From mid-July onwards, the introduction of a military presence on the ground in former Yugoslavia was always a 'more or less explicit goal on the part of the Dutch Presidency'. ${ }^{20}$ Van den Broek and his senior advisers believed that the EC's political approach required some military component if it were to have a chance of success. Van Walsum's view was that the EC Foreign Ministers, by rejecting border changes, had 'effectively opted for a non-peaceful dissolution of Yugoslavia' and should now face up to the consequences of their decision and be 'prepared to use force to contain Serbia as the most aggressive and heavily armed party.'. ${ }^{21}$ The director of DAV, Boudewijn van Eenennaam, also quickly opted 'for the line whereby Serbia was isolated.'22 As the war in Croatia continued to escalate, opinion inside the Ministry thus began to favour a political isolation of Serbia and some form of military intervention to contain the Yugoslav army. Only the Eastern European Division disagreed and began to fight a rear-guard battle, advocating non-intervention and continuing to make the case for border changes. In doing so, the Eastern European Division isolated itself, lost influence and eventually ceased to be regarded by colleagues as a serious participant in the policy-making process. ${ }^{23}$

The Dutch movement towards 'selectiveness', which seemed to narrow the gap between the German and Dutch positions, could not be completed at this stage because it clashed with all three of the institutional interests referred to above. Any proposal that singled out Serbia for punitive action 
would run into the opposition of France and several other member states and thus cause the split the Dutch EC Presidency sought to avoid. At the same time, no anti-Serbian selectiveness on the part of the Dutch Presidency veered far enough from the German point of view because it did not include the most 'selective' policy of all: an early recognition of Croatia and Slovenia. When, for instance, Germany repeated on August 6 its earlier call to threaten Serbia with a recognition of Croatia and Slovenia, the Dutch Presidency refused to reopen the debate on recognition, receiving support in that position from 'the vast majority of the EC-partners'. The desire to contain Serbia and the Yugoslav army was real, but could not be satisfied without splitting the EC and undermining the Dutch Presidency. Prepared to intervene, but not to recognise, the Netherlands entered a 'neither-nor' period, in which it favoured selectiveness but not at the expense of EC unity. This attitude lasted until October 10, when an unequivocal choice in favour of selectiveness was made.

The Dutch desire for some form of intervention clashed with the stated Dutch interest in NATO and US leadership in international security. This meant, for instance, that the Foreign Ministry long refused to give serious thought to the idea of involving the Western European Union (WEU). According to the former Dutch WEU Secretary-General, Willem van Eekelen, 'Hans van den Broek had no desire to involve WEU in the middle of the debate on its role in the future Political Union. ${ }^{24}$ For this reason also, the Dutch Presidency had decided to organise the monitoring mission agreed to in Brioni itself, obtaining an endorsement from the CSCE rather than turning to the WEU to implement the mission. ${ }^{25}$ While the Dutch vehemently opposed involving the WEU in the management of the crisis, for fear of undermining NATO, the aloofness on the part of the United States made it impossible to count on a NATO intervention instead. Thus the Dutch Presidency found itself in the paradoxical position of supporting some form of military intervention on the one hand, while on the other hand refusing to use the only platform theoretically available for such an intervention at this point in time, the WEU.

Caught between their love for NATO and their desire for some form of intervention in the Yugoslav crisis, the Dutch seemed inconsistent in their policy regarding military intervention. Thus, when France on July 25 proposed to send a WEU 'interposition' force to Croatia and let it be known that it wanted the WEU to become 'the full-blown defence arm of the EC', 
both the "UK and the Netherlands resisted the idea..., because of the damage it could do to the NATO partnership. ${ }^{26}$ (Curiously, by mid-September, it was the Dutch EC Presidency itself, which was to propose the deployment of a WEU-interposition force.) Nevertheless, despite the apparent contradiction, Dutch policy simply remained true to its traditional twotrack approach of promoting supranational integration inside the EU in all fields except security, where NATO should remain the lead organisation.

Notwithstanding the inevitable brake which these institutional interests put on the movement towards a selective approach, this was the path now favoured by the Dutch. Indeed, so great was the desire for action on the part of the Dutch officials that any idea for introducing an external presence on the ground in Croatia was taken up enthusiastically, sometimes mistakenly. Four days after the rejection of the French proposal the Netherlands supported the ministerial decision of July 29 to extend the activities of the EC Monitoring Mission (ECMM) to Croatia. In addition, Van den Broek suggested that the EC propose to the Yugoslav parties that they set up 'mixed patrols' of units of the Croatian national guard and the JNA and, possibly, the EC monitors. Germany and Belgium criticised the Dutch proposal for failing to take into account that the JNA had effectively taken sides with the Serbs. The idea eventually came to nothing. ${ }^{27}$

In the heated atmosphere of The Hague and given the strong desire 'to do something, very few people had noticed that Van den Broek's proposal to set up 'mixed patrols' was the fruit of a misunderstanding between officials of the Eastern European Division and the Atlantic Cooperation and Security Affairs Department (DAV). At a meeting of officials dealing with Yugoslavia, a member of the Eastern European Division had mockingly suggested: 'why not work with mixed patrols, with an EC observer, a Croat and a Serb, three men in a jeep, the way it happened in Namibia?'28 Though meant as a joke, the idea was taken seriously. DAV officials developed the concept into the proposal carried to Brussels by Van den Broek and Kröner.

The Dutch Presidency was rather more fortunate in launching the ECMM. Seen widely as a successful example of common European action and as a valuable provider of intelligence information for the EC capitals, the Dutch Presidency is usually credited for having taken the mission 
seriously enough to make it work. Following the decision at Brioni to create it and the ministerial decision to extend its activities to Croatia if possible, Dutch officials had worked round the clock to find the necessary funding and manpower to get the ECMM up and running. The concept was worked out by a small team of DAV officials eager for the Netherlands to show that common action on the part of the member states was possible. The mission's terms of reference were drafted within seventytwo hours on the basis of the CSCE verification protocol. Kröner visited the EC capitals to raise the money and obtain personnel for the mission. The mission started operating in Slovenia in July, extended its activities to Croatia in September, and continued to serve as an important provider of first-hand information throughout the war in Bosnia-Herzegovina (and thereafter).

The month of August saw a continuous hardening of Dutch attitudes vis$\grave{a}$-vis the Serbian leadership and the Serbian-dominated Yugoslav army. This culminated in a proposal to single out Serbia and the Yugoslav army for a public condemnation by the EC and a threat to exclude it from negotiations regarding the future of the Yugoslav federation. If the proposal were adopted, it could also be the first step in the direction of some form of military response to the Yugoslav army's actions in Croatia. Events on the ground in the Yugoslav conflict, sometimes witnessed by Van den Broek's newly appointed trouble-shooter, Ambassador Henry Wijnaendts, did much to confirm the need for a tough response on the part of the EC. (Wijnaendts, a former Director-General for Political Affairs, now resided in Paris as Ambassador to France. Over the course of the next months, he was busily engaged in several rounds of shuttlediplomacy, attempting to obtain the agreement of the Yugoslav parties to various EC proposals. In this position, Wijnaendts witnessed the destruction of Vukovar. ${ }^{29}$ Since the first direct clash, on July 25, between the Yugoslav army and the Croatian guard it was now obvious to all that the Yugoslav army had sided with the Croatian Serb militias. By far the most important event on the ground to cause a hardening of Dutch attitudes was the behaviour of the Yugoslav army around the Croatian border town of Vukovar. Already on July 3 the Embassy in Belgrade had warned The Hague that 'a unit at brigade-strength of around 3,000 men, a great number of tanks, mortars, artillery and other military equipment' was leaving Belgrade in the direction of Croatia. Speculating on the unit's assignment, Ambassador Fietelaars had written: 'it is also possible that they are 
on their way to the surroundings of Vukovar, a hotbed of inter-ethnic fighting in Croatia, in order to be able to prevent a large-scale confrontation between Croats and Serbs. For this, however, the force is actually much too large.' The exact assignment of the force became all too clear when in August, following additional JNA reinforcements, Vukovar came under shelling from the JNA artillery, sporadic at first but intense from the third week onwards. The offensive against Vukovar seemed to confirm that the JNA and the Serbian leadership were in cahoots.

The Dutch now realised that the time was right for the Presidency and the EC as a whole to take a stand or else risk inviting the wrath of international public opinion. The following exchange illustrates the changing mood inside the Foreign Ministry. In reply to yet another unorthodox plea for restraint by the Eastern European Division and their suggestion to suspend mediation efforts until the Yugoslav parties showed themselves more willing to cooperate, Van Walsum simply replied: 'Even if doing nothing is objectively the best course of action, experience teaches one that that is not politically practical. All twelve Ministers are under pressure to do something.'

Dutch officials frantically searched for ways to respond to the Serbian aggression without being forced into a rerun of the debate on recognition. Thus on August 23 the Eastern Europe Division sent a memorandum to Van den Broek, via Van Walsum, in which they noted: 'Now that as a consequence of Serbian violence increasingly large parts of Croatia have fallen into the hands of the Serbs, it seems useful to forcefully take a stance against this... This could be done by means of a message of the Twelve that is supported by the Central and Eastern European countries, the Soviet Union and the US.' Van Walsum took up the suggestion in a somewhat different form.

The best platform for a tough message to be formulated, Van Walsum believed, would be the upcoming ministerial meeting of September 3. In preparation for that meeting, the political directors were to meet on August 28. Evidence that Van Walsum was planning to draft a tough declaration was provided by a written response to a suggestion from elsewhere in the bureaucracy to organise secret, EC-chaired, talks between Tudjman and Milosevic. Van Walsum opposed such talks and scribbled onto the memo: 
I propose this scenario: - Wed[nesday] 28 Aug. Co[mité] Po[litique]: Tough declaration against violence, so implicitly against Milosevic + JNA. (...) Secret meeting Tudjman and Milosevic must not deal with carve-up of Bosnia-Herzegovina. (...) Talk is therefore not timely. First comes pressure. Tough declaration of next Wednesday fits into that.

The text drafted by Van den Broek and Van Walsum was indeed the toughest so far and exploited to the full the limited means of pressure at the disposal of a civilian power like the EC. The episode that followed constituted a source of pride and frustration on the part of the Minister and the Director-General for Political Affairs. Proud that they had drafted the toughest declaration the EC Foreign Ministers could possibly have issued, they were disappointed to find that the necessary support for the text itself, and the selective approach associated with it, was lacking. The greatest disappointment and a major source of frustration was the fact that German Foreign Minister Genscher, who had consistently advocated isolating Serbia and by whom, the Dutch thought, their draft would be warmly welcomed, gave only half-hearted support.

The Dutch text, which had been drafted on August 27, explicitly condemned Serbia and the Yugoslav People's Army for their fait-accompli policy in Croatia. It warned that this policy could never succeed in effectively protecting the Serbs in Croatia because the international community would never recognise borders that had been changed through force. The text stated that an effective cease-fire, monitored by the international community, was an absolute precondition for fruitful negotiations and called upon Serbia to give up its resistance to an expansion of the EC Monitoring Mission to Croatia. Crucially, the sanction proposed by the Dutch Presidency, if Serbia were to refuse to heed these calls, would be the exclusion of Serbia (and Montenegro) from EC-chaired negotiations regarding the future of Yugoslavia. The implicit threat was clear: without Serbia such talks could easily result in an agreement to recognise individual Yugoslav republics as independent states.

The Dutch EC Presidency thus for the first time showed a willingness to adopt an anti-Serbian selectiveness. It was prepared to try and build a consensus around the possibility of a settlement to which Serbia and Montenegro would not be party, which would in turn open the way 
for an armed response of some sort to Serbian cross-frontier military activities. The Dutch were not yet ready to give explicit support to an early recognition as such; nor were they eager to repeat the debate of June and July over that issue, the deceptive simplicity of which - one was either for or against recognition - had divided the member states. Nevertheless, the Presidency's draft should have taken away any doubts on the part of Germany as to whether the Netherlands was prepared to accept recognition as the eventual outcome.

So what went wrong? There had been much less time to draft the text and prepare the EC partners for it than the Dutch had envisaged. This was due to the fact that, at German insistence, the ministerial meeting had been brought forward from September 3 to August 27. There had not been a possibility for the political directors to prepare the ground for the Ministers. In fact, Van den Broek and Van Walsum had drafted considerable sections of the text in their car, during the two hours or so it took them to reach Brussels for the GAC. It was expected that French Foreign Minister Roland Dumas would try to water down the text, given France's preference for continuing an even-handed approach. En route, Van den Broek and Van Walsum put additional flesh on the draft, 'so that it could take some scratching. ${ }^{30}$ The result, according to Van den Broek was a 'rock-hard anti-Serbian declaration'. ${ }^{31}$ Upon arrival he showed the draft declaration to Genscher who was, as expected, visibly enthusiastic.

Genscher's enthusiasm did not, however, translate into strong support when the Council went into session. Under normal circumstances, Genscher would probably have gone to great lengths to help preserve the Dutch draft. However, Genscher had telephoned Dumas and arranged a private meeting in advance of the GAC. According to Genscher, the intention of the call was to reconfirm the importance of the French-German relationship and to give a new impulse to the EC's involvement in the Yugoslav crisis. ${ }^{32}$ Impatience with what the Germans saw as Dutch obstinacy regarding the recognition issue, as well as the personal animosity between Genscher and Van den Broek, probably also played a role. During their private chat, Genscher and Dumas agreed to present their colleagues with a French-German initiative. Genscher's input to the proposal consisted of an EC-sponsored conference involving, crucially, all the Yugoslav parties. (In actual fact, it had been the British who had first proposed, on August 2, to organise a conference.) Dumas, for his part, introduced the 
idea of an arbitration commission, which he later explained might be able to 'substitute violence with arbitration'. ${ }^{33}$ The French-German initiative was based essentially on what had hitherto been seen as French and British, rather than German, ideas and reconfirmed the Community's even-handedness towards all the Yugoslav parties. The problem for Genscher, upon being presented with the Dutch draft, was that the approach he favoured clashed with the one he had just promised to co-sponsor. As a result, more was taken out of the text than the Dutch had expected.

At the Council meeting, Dumas immediately sought to stymie the possibility that the Dutch draft would be accepted as it stood. He offered the all-party conference and the arbitration commission as an alternative to the Dutch idea of a conference without Serbia and Montenegro. Moreover, he criticised Van den Broek's proposal as too anti-Serbian. This French concern was also echoed by Britain and, especially, Greece. The rest of the line-up was as follows: the Spanish, Luxembourg and Irish Foreign Ministers argued that while the analysis of the Presidency was correct, the criticisms of Serbia should be moderated. Denmark, Belgium, Portugal, Italy and the Commission all more or less supported the Dutch draft as it stood. Italian Foreign Minister De Michelis, Commission President Delors and Portuguese Foreign Minister De Pinheiro all spoke strongly in favour of the Dutch draft, pointing out that a political isolation of Serbia was the only weapon available to the EC. The outcome of the discussion, which lasted until $00.30 \mathrm{hrs,} \mathrm{depended} \mathrm{largely} \mathrm{on} \mathrm{the}$ stance Germany's Foreign Minister would take.

While Genscher spoke sympathetically of the Dutch draft, he was in no position to drop the French-German initiative introduced by Dumas. $\mathrm{He}$ solved his dilemma by proposing to combine the two initiatives. Despite criticisms from representatives such as De Michelis that this undermined the strength of the original Dutch proposal, this was the road taken. The compromise eventually reached encompassed a watered-down version of the Dutch text, as well as the EC Conference and the arbitration commission. The result was an inconsistent mish-mash of separate ideas, leaving the Serbian leadership much more room for manoeuvre than the Dutch draft would have done. In particular, the Serbs could, as a 'concession', now give access to the monitors in exchange for participation in an allparty conference. Such a favourable deal for the Serbs had been absent in the Dutch draft. 
Despite the disappointment on the part of the Dutch, the declaration, issued on the morning of August 28, was the toughest so far, stating, for instance that 'elements' of the Yugoslav army were actively supporting the Serbian side. The EC governments would never condone a fait-accompli policy, although the declaration did not identify Serbia as the culprit, as had been proposed by the Dutch. Serbia was, nonetheless, warned that the EC would organise a meeting with the 'cooperative' parties in order to 'discuss additional measures, including international action' if before September 1 it had not agreed to an EC-monitored cease-fire. Van Walsum was later told by a Slovenian official that the Slovenes had interpreted the use of the term 'fait-accompli policy' as the first step towards recognition of their independence. ${ }^{34}$

\section{Back to Even-Handedness: August 28 - October 10, 1991}

The ministerial meeting of August 27 was not the first nor the last time the Dutch and the Germans should have been able, but failed, to take up a common position. The Dutch EC Presidency formulated a policy that could, in theory, have helped the shaping of a majority stance within the EC around what was - and still is widely- seen as the exclusively German line. The negative German response seems to have upset the Dutch and motivated them to recoil from their selective stance and head back for the safety of even-handedness. This might invoke the wrath of Germany but it reduced the risk of being caught between the majority line of support for even-handedness and a Germany that in the final analysis gave primacy to the German-French axis over the substance of the EC's policy towards the Yugoslav crisis.

The discussions of late August 1991 show that Germany missed an opportunity to gain early EC support for its pro-recognition stance. The German literature has generally glossed over the episode and, furthermore, continued to look back on Dutch policy as totally opposed to recognition. In his memoirs, Genscher is admittedly frank about his meeting with Dumas and the resulting French-German initiative but he does not mention the Dutch proposal. Nor does he explain that the French-German initiative in essence constituted a German concession to France at a point in time where the Dutch Presidency and, probably, other EC member states were seriously considering abandoning the impartial line so far maintained. Hans-Heinrich Wrede, who was the 
German Foreign Ministry's deputy-head of the Yugoslavia Crisis Staff, simply referred to the August 28 declaration as a confirmation of German policy: 'With some delay, the other EC Foreign Ministers also took up this [Genscher's] view.' ${ }^{35}$ Viktor Meier, whose furious attacks on Dutch policy in the Frankfurter Allgemeine Zeitung greatly helped to sour Dutch-German relations, seems mistaken in his conclusions regarding the August 28 ministerial declaration. According to Meier it was the line 'represented by Van den Broek' which 'led directly to the Hague [EC Peace] Conference'. In fact, as Genscher admits, it was he who proposed the Conference as his input into the French-German initiative of August 27/28. Meier augments his omission by falsely stating that the Conference was 'proposed by France.' ${ }^{36}$

An important factor in explaining the failure of the Dutch and the Germans to join forces was the exceptionally poor state of relations between the two countries around the turn of the decade. Beneath a shared desire for further European integration, the personal relations between the two countries' top politicians soured dramatically during the late 1980s and early 1990s. The main cause of these personal-political antagonisms between the long-serving leaders of the Netherlands and Germany probably lay in the German reunification, the expected growth of German power and the concern this caused in the Netherlands. According to Kohl's adviser Horst Teltschick, Lubbers and Van den Broek were among the minority of Western politicians who were 'decidedly cool' about the prospect of German reunification. ${ }^{37}$ Several Dutch officials remember a clash between Genscher and Van den Broek during a meeting in February 1991, one of whom recounts: 'Genscher expatiated emotionally and impressively about German reunification. He referred in a penetrating way to his youth in Halle. It was so quiet that you could hear a pin drop. When Genscher had finished, Van den Broek took the floor and held a 20-minute Philippic in which he made it clear why there could be no German reunification for the time being. It was very painful and I believe that this was the beginning of the antagonism between Genscher and Van den Broek.'38

Following German reunification, the personal antagonisms only became worse, as Dutch concern rose over the perceived monopoly of the FrenchGerman axis over matters European. Dutch-German differences eventually led to another painful episode in 1994, when Kohl conspicuously 
refused to support the candidacy of Lubbers for the Presidency of the European Commission. ${ }^{39}$ No wonder, then, that Dutch and German politicians had difficulty in identifying common ground with regard to the EC's approach to the Yugoslav crisis.

The draft-declaration of August 27/28 had not only been an important break with past Dutch Yugoslavia policy, but had also constituted a major opportunity to repair some of the damage done to Dutch-German relations in past times. The German rebuttal instead poured salt into the open wound. As the Dutch reverted to the majority stance of even-handedness, thereby inviting renewed German criticism, it became practically impossible for the two foreign Ministries to conduct sensible discussions on how to proceed. Instead, the two countries began to pursue two different tracks. Germany began to increase the pressure on the remainder of the EC in favour of a recognition of Croatia and Slovenia, while the Netherlands - paradoxically - focused its energy on supporting the EC Peace Conference.

The EC Peace Conference's first session was held on September 7, and throughout that month, the Dutch focused on ensuring maximum support for the Conference and its chairman, former British Foreign Secretary Peter Lord Carrington. The Conference, the Presidency (despite the Dutch scepticism about the Conference's chances of success) and the majority of EC member states concentrated on achieving a negotiated settlement. This was in line with the EC ministerial declaration of September 6, which had spoken of the necessity of speaking with a single voice so as to give the Conference legitimacy. Germany, instead, began to push openly for recognition of Slovenia and Croatia, seeking the support of like-minded EC member states.

To illustrate the widening gap between Dutch and German policy, one needs only to look at the activities of both countries' Foreign Ministers in mid-September 1991. On September 14 Van den Broek received Croatian Foreign Minister Zvonimir Separovic in The Hague. Van den Broek had been informed by Wijnaendts that the Croats felt encouraged by the August 28 declaration and were now responsible for most of the escalation in the fighting in Croatia. ${ }^{40}$ Given that Croatia's cooperation was required if the EC Conference was to successfully negotiate a settlement, Van den Broek pointed out to Separovic that, despite the tough-sounding 
declaration, Croatia should not pin its hopes on a European military intervention which was 'out of the question'. He also accused Croatia of deliberately escalating the war and jeopardising the Conference that had just started in The Hague. Genscher, for his part, took a completely different road. On September 15 he and De Michelis held a bilateral meeting in Venice. Afterwards, the two Foreign Ministers told the assembled press that if peace negotiations between the warring parties broke down, Germany and Italy would be obliged to recognise the declarations of independence of Croatia and Slovenia. They were ready to do so even if the rest of the EC member states refused to do so. ${ }^{41}$

The conflicting approaches caused an immediate and angry quarrel between The Hague and Bonn. While the Presidency sharply criticised the German-Italian declaration of Venice for undermining the Conference and the cohesion of the EC, Germany was furious about the Dutch criticisms of Croatia. The mutual irritation came to the surface on September 16. The Dutch Presidency distributed a telegram to its partners, which delivered a sharp and outspoken attack on the Venice meeting. It expressed concern that the remarks by the two EC member states might encourage Croatia to disengage from the Conference. Germany countered by inviting Dutch Ambassador Jan van der Tas to the German Foreign Ministry. In Bonn, Van der Tas was subjected to some strong criticisms of the Dutch position. A senior German official told Van der Tas that the Dutch allocation of guilt to the Croats, as well as Dutch references to growing German assertiveness were seen in Bonn as a burden on German-Dutch relations. The remarks by Dutch officials, as they had been reproduced in the German press, were interpreted by Bonn as directed specifically against Foreign Minister Genscher. The Dutch Ambassador did not leave without retorting that the German press had embarked on a veritable smear campaign against the Dutch Presidency, against his own Minister in particular, and that accusations like 'conspirator with a minority of EC-countries' were below the belt.

Greatly frustrated by the perceived attempts on the part of Germany to discredit the Dutch Presidency, Van den Broek decided to call his German colleague's bluff by proposing a military intervention. ${ }^{42}$ The Dutch realised full well that Germany, on the one hand, would be morally obliged to support such an intervention, but would probably be unable to participate for constitutional reasons. The proposal would therefore at 
best lead to a military intervention and thereby enhance the prestige of the Dutch Presidency or, at worst, fail because of a lack of support for which Germany for one, but certainly not the Netherlands, could be blamed.

The Dutch proposal was made public on September 17. The idea was that the Europeans would deploy a 'lightly armed' WEU-force to Croatia to protect the EC monitors. 'Dutch officials said the idea of the force was not to impose a cease-fire but rather to use a European show of arms to discourage a resumption of warfare after a new cease-fire goes into effect.' ${ }^{3}$ Remarkably, the proposal seemed to imply that the Dutch had abandoned the principle that any military involvement in Yugoslavia should be NATO-led. In reality, the reasoning behind the proposal was that WEU involvement would inevitably trigger NATO involvement. It was thought that soon after a form of intervention had been launched under the WEU flag, France would find out that NATO's command and control facilities were indispensable. The USA, in turn, would heed calls for support from their allies and reinforce the operation. A NATO intervention would have been engineered. Had the proposal been accepted, the Dutch would have squared a circle: German critics would have been silenced; a selective approach would have been adopted without splitting the EC on the question of recognition, while the Dutch interest in continued NATO cohesion and US leadership would have been protected.

Unfortunately for the Dutch Presidency its proposal came to nothing. Over the next month or so various contingency-plans were drawn up, involving several lighter and heavier options. But no option could attract the support of a majority of WEU and EC member states. By the end of September, when British Foreign Secretary Douglas Hurd expressed serious reservations about the existing contingency planning, the European debate on military intervention had been concluded firmly in the negative. Thereafter, the UN became the main platform for the discussion of military options.

Despite the German-Dutch dispute and regardless of the latter's formal support for the EC Conference, it was obvious to the officials in The Hague that recognition could not be withheld indefinitely. In his analysis of the EC's diplomacy in 1991, Meier claims that the lack of progress around the negotiating tables of the Hague Conference, was in large part 
due to the 'negative' role played by 'Van den Broek and his people.' Dutch 'politicians, diplomats and military monitors' were the 'catalysts' of the 'EC-debacle'. ${ }^{44}$ Moreover, according to Meier, Dutch officials tried 'everything in their power' to extend the three-month moratorium on the implementation of Slovenian and Croatian independence agreed at Brioni. In reality, Van den Broek and his colleagues were facing a difficult dilemma: how could the Dutch EC Presidency pave the way towards a recognition of Slovenia and Croatia and at the same time avoid being accused by Britain and France of having given up on Carrington's Conference?

Van den Broek later described the continuing dilemma between selectiveness / recognition and even-handedness / the Conference: 'On the one hand the common philosophy was to first have a general settlement and only then to recognise. Genscher opposed that. On the other hand, it quickly became obvious that this was a case of might makes right. A situation arose whereby one had to admit to Genscher that a peaceful fragmentation was no longer possible. We faced the dilemma to either proceed towards a premature recognition, or to have a divided [European] Union. This continued to play until the end.'45 There exists written evidence that Dutch officials were thinking of the implications of the expiry of the three month moratorium and of a possible response to it. A diplomat who had been seconded to Carrington's secretariat at the Conference wrote to Van Walsum that it might in the near future become necessary to deal in a creative way with the question of recognition of Yugoslav republics. The pressure to undertake something in that direction is increasing, witness also the German-Italian ministerial meeting of September 15 in Venice'. According to the official there was 'a conceivable scenario, in which recognition constitutes an option that, provided it is couched in safeguards, can contribute to a continued cohesion of the ECmember states. He went on to advise that the EC, though not its member states, would recognise the 'claim to independence' of all republics, including those who had not asked for it, but to announce that recognition would not be put into practical effect until a general settlement had been reached. Van den Broek opted for a slightly different line, which was announced to the Yugoslav parties on October 10. 


\section{Selectiveness: October-December 1991}

On October 8 and 9 Van den Broek spent hours on the telephone talking to European and American politicians to tell them he intended to set a two-month deadline to the talks chaired by Lord Carrington. If no settlement had been achieved by December 10, a decision to recognise individual Yugoslav republics would automatically have to follow. This new policy was hardly known at the time and remained largely unknown in the Dutch, British and American literature on the subject. ${ }^{46}$ However, the evidence suggests that the proposal was instrumental in opening the way to a decision in favour of recognition, the most selective policy available to the EC.

There were several important reasons for Van den Broek to set the deadline. The first was to save the Dutch EC Presidency from disgrace. As Europe's failure to stop the war in former Yugoslavia was becoming ever more obvious there was a growing concern in The Hague that the Dutch EC Presidency would end up becoming a scapegoat for that failure. That this fear was not wholly unrealistic was confirmed in a private assessment for the attention of Van Walsum, drawn up by a Luxembourg diplomat who had been seconded to the Dutch Presidency in the framework of the Troika: 'One observes that the partners are increasingly inclined to take up positions in public which are easily sold to the media before withdrawing behind common positions while attacking the Presidency for its inactivity or its lack of resolve.'

Further indications of the possibility that the Dutch Presidency might find itself completely isolated at some point, were provided by the events of September 30, 1991, or 'Black Monday' as it is usually referred to in Dutch policy-making circles. ${ }^{47}$ That day the Dutch Presidency suffered a particularly humiliating defeat, albeit largely self-inflicted, in the negotiations for a treaty on a political union. The Dutch had prepared a draft treaty, which consisted of what was widely judged to be a contradictory blend of overly federalist proposals for a political and economic union, and pro-NATO proposals in the field of defence. On Monday September 30 the draft was presented to the EC partners and after a short meeting rejected by all but Belgium. The fact that Germany - against earlier expectations - had not supported the Dutch proposals came as a profound shock to the Dutch. After 'Black Monday', the Dutch government 
was determined to save the Netherlands' EC Presidency from further disaster, and not to let the Netherlands be a scapegoat for the EC's unsuccessful handling of the Yugoslav crisis. ${ }^{48}$

Another important question which the Dutch sought to address with the deadline proposal, given Germany's attitude in September, was how long that country would be able to resist the domestic pressure to go solo. The increasingly obvious answer was 'not very long'. The ever-stronger German pressure on the Dutch, which combined public criticisms with private warnings that Bonn would, if necessary, break ranks and recognise Croatia and Slovenia single-handedly, called for a change of tune on the part of the Presidency. The Dutch were still reluctant to give in to their arrogant big neighbour but were equally concerned about the image of the Dutch Presidency as it was being painted internationally by the German foreign policy establishment. Moreover, Dutch officials could not help admitting that they essentially agreed with the German analysis: to postpone recognition was to play into the hands of the Serbian leadership. Van den Broek and his senior advisers, that is Wijnaendts, Van Walsum and Van Eenennaam, concluded that now was the time to steer the EC towards recognition. As such, the deadline fitted neatly into the Dutch views on the conflict itself and the prevailing scepticism as to whether an all-party conference could contain, let alone punish, Serbia and the JNA. However obvious it was that recognition should now be the goal to work towards, it was important to give the Conference a fair chance of negotiating a settlement, at least in theory. To close ranks with Germany completely would bring as great a risk of division as to let Germany go at it alone. Countries who wanted to keep open the possibility of a general settlement for the whole of the former Yugoslavia might respond furiously and blame the Presidency for having undermined the Conference. A deadline, it was hoped, would be acceptable to both poles of opinion within the EC. It gave the Conference two more months, but made recognition the inescapable outcome if the talks were to fail.

On October 4 the Conference apparently achieved a remarkable success. All parties, including Serbia, agreed that recognition might be the outcome of the negotiations. This outcome was produced in a private meeting between Carrington, Van den Broek, Tudjman, Milosevic and Yugoslav Defence Minister General Veljko Kadijevic. Following the meeting, Van den Broek announced that the EC had obtained the 'acquiescence of 
all Yugoslav parties present at the plenary meeting' for an agreement that 'included the principle that a political solution should be sought on the basis of the perspective of recognition of the independence of those republics who wished it, at the end of a negotiating process conducted in good faith and involving all parties.'

The result of the October 4 meeting was discussed and applauded by the EC Foreign Ministers on October 5 and 6 in the castle of Haarzuilens in the Netherlands. Van den Broek remarked to his colleagues that 'from the agreements of October 4 it could be gathered that the Serbs too now seemed to accept the perspective of recognition'. Nevertheless, given that it was extremely difficult to gauge Serbian motives - why continue to wage war in a country whose borders you have publicly promised to respect? - Van den Broek subsequently proposed to 'set an ultimatum with regard to the implementation of the agreements of October 4'. His colleagues agreed and Van den Broek and his officials sat down to formulate one.

On October 8 and 9 Van den Broek proposed that the ultimatum should be a two-month deadline. In many hours of telephone conversations the Foreign Minister consulted Genscher, Dumas, De Michelis, Hurd and US Secretary of State Baker about the idea of setting a two-month deadline for, on the one hand, the withdrawal of the JNA from Croatia and, on the other hand, the signing of an overall settlement. ${ }^{49}$ Van den Broek obtained the consent of colleagues like Hurd and Dumas by promising to stick to the October 4 agreement, which stipulated that recognition would be 'granted in the framework of a general settlement'. Hence, the firmness of the deadline still seemed open to interpretation. To Genscher, on the other hand, the two-month deadline constituted a confirmation of German policy and became a fixed, agreed, deadline for either a settlement or recognition on December 10, 1991.

Lord Carrington, who was in New York for a meeting with the UN Secretary General, remembers that, when told, he believed the idea 'wholly unrealistic'. ${ }^{50}$ As the Dutch position hardened throughout October, Lord Carrington became increasingly concerned that the Conference would disintegrate, for what would be the incentive for the Croatian and Slovenian governments to accommodate Serbian or international demands at the Conference when all they needed to do was to sit tight for another two 
months and wait for the recognition of their republics to follow automatically? But whether the deadline undermined the Conference was not a point that much bothered the Dutch any longer. What The Hague wanted was a political outcome before the end of its term as holder of the Presidency. As Van den Broek later admitted, the deadline-proposal was meant as a 'means of pressure on the Serbs, not on the Croats and the Slovenes.'51

The deadline proposal was put to the Yugoslav parties on October 10, 1991. Miraculously, after five hours of talks, Van den Broek was able to announce to the press that all parties had agreed to a two-month deadline for the withdrawal of the JNA from Croatia and achieving a general settlement. Ironically, even Milosevic conceded in public that such a deadline was 'realistic, assuming that all parties cooperate. ${ }^{52}$ This was probably a fake-concession and a result of Milosevic's recognition that the deadline was going to be imposed on the Conference anyhow. What is more, the Yugoslav army subsequently let it be known that it would not withdraw from Croatia.

While a sceptical Carrington was still in New York, Wijnaendts as his deputy distributed a memorandum to the Conference's staff, laying out the precise timetable:

I therefore think that we should have at the latest within two months an agreement... That would also be the point in time to have a concluding and solemn session of the Hague Conference. That would also be the latest occasion for the Twelve to take a decision on the recognition of the independence of those republics that have expressed through a democratic process their will to be independent..$^{53}$

If there were still any doubts in London and Paris as to whether the Dutch had joined the German position, these should have been removed by an interview which Van den Broek gave to the Austrian newspaper Die Presse. In the interview, he indicated that recognition would automatically follow at the end of the two months if no overall settlement had been reached: 'This solution must be found within one month. The negotiations can be prolonged for the maximum of one more month. At that moment in time there must be a political settlement and the JNA must have been completely withdrawn from Croatia... If this does not happen, the time will have come for the EC to decide on the recognition of Slovenia and Croatia.'54 
Just how determined the Dutch had become to achieve a recognition before the end of their term as Presidency can be seen by the deliberateness with which they subsequently proceeded to isolate Serbia from the rest of the Conference. For some time the Dutch had believed that the best way to isolate Serbia politically was to hold a conference of 'cooperative' republics only. Instead, the EC had decided to organise an all-party conference. Initially loyal, Van den Broek and his advisers quickly became impatient as German pressure increased, the JNA's behaviour around Vukovar and, later, Dubrovnik became ever harder to stomach and the Conference apparently failed to make substantial progress. These factors combined to create a shared view among Van den Broek and his senior advisers that what was needed was a return to the August 27/28 concept. Serbia would need to be identified as a 'non-cooperative' republic and excluded from the Conference. As a result, the road to recognition would lie open, and an outcome would be obtained before the end of the Dutch Presidency.

As could be expected, Serbia itself was a great help in the search for a legitimate reason to exclude it from the Conference. On October 18, Milosevic refused to agree to the 'Arrangements for a General Settlement' which Lord Carrington had presented. This paved the way for an isolation of Serbia. In response, Dutch officials began to identify ways of singling out Serbia for punitive measures. First the principle of distinguishing between 'cooperative' and 'non-cooperative' republics had to be established as a starting point before one could proceed to isolate Serbia. Thus, on October 23, Van Eenennaam sent a memorandum to Van Walsum, stating that a 'distinction between cooperative and non-cooperative parties' was 'an essential ingredient of any attempt at mediation in a conflict'. Ambassador Fietelaars backed up Van Eenennaam's argument and called for an isolation of Serbia at the Conference: 'Serbia has in substance given up on the Conference and probably on a peaceful solution. Probably isolation of Serbia is now the best modus operandi.'

Van den Broek personally devised the tactical approach by which Serbia should be identified as a non-cooperative party. On October 24 he issued precise instructions in a long telephone conversation with Van Walsum, who was to pass these on to Wijnaendts as deputy chairman of the Conference. Subsequently, Van Walsum wrote a message to Wijnaendts and summarised Van den Broek's instructions on how the chair should 
handle the next day's plenary session of the Conference. Serbia, argued Van den Broek, would have to accept Lord Carrington's plan and be told that there was no room for the approach it favoured, which was a continued existence of the Yugoslav federation for those who did not wish to secede. Then, if Serbia would refuse to cooperate with the Conference on the basis of Carrington's plan, Serbia would have identified itself as a non-cooperative party. Once that had happened, the Presidency would call for a meeting of the EC Foreign Ministers and offer proposals in the spirit of the 'ultimatum' agreed to at Haarzuilens on October 6. These could be recognition of cooperative republics, the introduction of a package of selective sanctions, or both.

The meeting of Foreign Ministers envisaged by Van den Broek took place over lunch on October 28. The day before, the JNA's shelling of Dubrovnik had been condemned in a declaration and the meeting took place in a heavy, emotional atmosphere with Van den Broek and Genscher in particular calling for tough measures. Van den Broek argued that 'it was now a matter of putting the Serbs under pressure and forcing them to take up clear positions at the next plenary session of the Yugoslavia conference' on November 5. He proposed to threaten Serbia with 'restrictive measures' if it refused to accept Lord Carrington's draft settlement. Genscher supported the idea and, despite opposition from Dumas, the Ministers agreed to issue a declaration on that basis. The declaration issued on October 28 stated that if Serbia did not give up its opposition to Carrington's proposal, the Conference would 'proceed with the cooperative Republics' and that 'non-cooperating parties' could then expect 'restrictive measures by the EC and its Member States.' Also, Serbia was warned that the EC would ask the UN Security Council to adopt further restrictive measures.

The selective approach originally formulated by the Dutch Presidency was further formalised by the EC Foreign Ministers on November 8 in the margins of a NATO summit in Rome. Three days before, Milosevic had refused to accept the draft settlement and had expressed his republic's 'great bitterness' over what he called, 'the ultimatum and threat' contained in the European Community's declaration of October 28. The declaration issued on November 8 , in turn, listed a number of measures that the Community had decided to take, in particular the suspension or termination of various trade and aid programs. In addition, the Security Council was invited to impose an oil embargo. 
The fall of Vukovar on November 18 provoked a mood change in the Dutch Foreign Ministry. It seems that in the eyes of senior Dutch officials this event tilted the Yugoslav crisis from the political to the moral level. The existing anti-Serbian selectiveness was continued but acquired a new, sharper-edged quality that could not always be reconciled easily with the stated Dutch interest in maintaining EC cohesion. Principled beliefs about right and wrong began to constitute a more important ingredient in the mixture of domestic sources of Dutch foreign policy. This mood shift from an interest-driven policy to an idea-driven policy was described in an interview with three officials by Vrij Nederland: 'Because the Serbs used ever more violence, opinions began to turn increasingly against them. ${ }^{\prime 55}$ Nevertheless, precisely because these beliefs fitted so well in the already existing framework of selectiveness, there was no immediate clash between principles and interests. Moreover, the institutional interests related to the position as EC Presidency remained, on balance, the dominant forces restraining the growing Dutch temptation to push for policies that could not count on sufficient international support.

The best illustration of the mood-change inside the Foreign Ministry was a memorandum by Van Walsum to Van den Broek. The memorandum was sent on November 19 and constituted a kind of formalisation of anti-Serbian selectiveness. Several senior officials later explained that Van Walsum's November 19 memorandum marked for them the definitive good-bye to 'even-handedness.'. ${ }^{56}$ In the memorandum, Van Walsum argued that the Dutch should 'clearly take sides against Serbia.' He continued: 'Taking sides against Serbia is an imperative because we are dealing with a conflict between two republics, one of which has appropriated the complete national army and the remainders of the national governmental bureaucracy. This is not a situation that can be sensibly approached with "even-handedness"' Van Walsum wanted the Netherlands as EC Presidency and the EC as a whole to consider 'applying so much pressure [on Serbia] through a selective and discriminating policy that it will sooner or later be prepared to compromise.' In conclusion, Van Walsum wrote: 'I realise that it will not be easy to convince all partners, but "even-handedness" can only lead us to having to miserably accept the Serbian conquests and their corresponding new borders in the course of 1992.' 
Vukovar also prompted a number of telegrams from the Dutch Presidency to the EC partners that were worded in the most explicitly 'selective' language used so far. The immediate triggers for the Dutch messages were, first, reports that the fall of Vukovar would be followed by an assault on the town of Osijek and, secondly, the discussions in the Security Council on the possibility of sending a peacekeeping force to Croatia as a buffer between the two sides. Van den Broek and Van Walsum had been sorely disappointed by a meeting with UN Under-Secretary-General Marrack Goulding and Cyrus Vance, the newly appointed UN special representative to Yugoslavia, at Schiphol airport the week before. ${ }^{57}$ Vance and Goulding had indicated that they thought a peacekeeping force should be deployed, not on the official borders between Serbia and Croatia, but on the existing front lines, between Serb and Croat forces. This caused a concern among the Dutch that the UN force would simply serve to consolidate the Serbian gains, a suspicion that was being reinforced by the enthusiasm on the part of the Serbian government for such a UN force to be deployed in Croatia.

When reports came in that Osijek would be the next target of the JNA, the Dutch Presidency decided to make a push for recognition and help forestall the deployment of a UN force that would consolidate the Serbian gains. The Dutch drafted a declaration to be issued by the EC. It stated that the fall of Vukovar and the subsequent attack on Osijek by the JNA and Serbian irregulars 'must rule out the deployment of a UN peacekeeping force' in Croatia. The draft distributed among the EC partners also argued that if attacks on Croatian towns and villages were to continue, the EC and its member states would 'have no choice but to proceed with recognition of Slovenia, Croatia and other interested republics within their established borders.'

The exchange that followed showed that, while there were still different views about the timing of such a decision, the principle of recognition was now supported by a majority of EC member states. To deal with the criticisms concerning the principle of recognition and the timing at which this should take place the Presidency sent a response that made clear it had given up on the idea of a negotiated settlement:

If the Twelve should take the view that the prospect of recognition of the independence of republics can only be envisaged in 
the framework of an overall settlement which involves all 6 Republics, they are powerless against one Republic blocking the process meant to achieve an overall settlement while in the meantime conquering territory...

Over the next few days, the issue of the UN peacekeeping force faded, but before it did, the Presidency sent another telegram showing how singlemindedly it was pushing the selective approach. Part of that approach, as we have seen, was the distinction between cooperative and non-cooperative parties. While a package of sanctions against Serbia had been announced on November 8 , in the absence of recognition of cooperative republics as independent states, there was a risk that they would suffer from the measures announced on November 8 . This had not been the intention behind the distinction between cooperative and non-cooperative republics. Hence, on November 25, the Presidency urged its partners to institute 'positive compensatory measures' favouring the cooperative republics. A package of such measures was adopted, despite some opposition, at the GAC of December 2. The 'cooperative' republics constituted Slovenia, Croatia, Bosnia-Herzegovina and Macedonia.

\section{Recognition: the 'Collective' Decision}

In the run-up to the ministerial meeting of December 16, where the recognition issue was to be settled, the course seemed obvious: recognition would indeed be the outcome. Precisely how inevitable governments judged recognition to have become was a matter of their perception of - and information on - other member states' positions. A considerable number of governments and Foreign Ministers were possibly unaware of the pro-recognition consensus apparently reached by Christian-Democrat government leaders and party-chairmen on Tuesday November 26. Meeting privately in Stuyvenberg castle near Brussels under the aegis of the European People's Party (EPP), six Christian-Democrat government leaders from EC member states, had gathered and agreed that the recognition of Croatia and Slovenia should take place before Christmas. The meeting was attended by Chancellor Helmut Kohl of Germany, Prime Minister Giulio Andreotti of Italy, Prime Minister Wilfried Martens of Belgium, Prime Minister Jacques Santer of Luxembourg, Prime Minister Ruud Lubbers of the Netherlands and Prime Minister Konstantin Mitsotakis of Greece. ${ }^{58}$ The Christian-Democrat pro-recognition consensus 
that had apparently emerged at this gathering of political leaders was referred to in a message from the Dutch Ambassador in Bonn on November 28 concerning other high-level meetings that day:

At the end of the conversation between Chancellor Kohl and Prime Minister Andreotti (after the meeting between Prime Minister Lubbers and Chancellor Kohl this morning) it was declared that Italy also intends to recognise, before Christmas, independent republics in Yugoslavia. During the Dutch-German meeting it was indicated that on this matter there was agreement between all (!) Christian-Democrat government leaders who were together in Brussels Tuesday evening in the framework of EPP.

Several EC government leaders had not been party to this meeting and were perhaps unaware of its outcome. For in contrast to later EPP declarations on e.g. Turkish EU-membership, the consensus reached on November 26 was not published. Even Van den Broek, himself a Christian-Democrat, claims to have been unaware (despite the message from Bonn). ${ }^{59} \mathrm{~A}$ former Cabinet colleague of Van den Broek and Lubbers thought it possible that Lubbers would either have not fully informed Van den Broek, or that Van den Broek would not have felt bound to the November 22 agreement due to the poor state of personal relations between the two. ${ }^{60}$

It is difficult to assess precisely what impact the EPP consensus may have had on the EC's handling of the recognition issue. According to Lubbers, to suggest that a pro-recognition consensus was reached at Stuyvenberg castle, is a 'bizarre' summary of events, in light of the pressure that had been exerted by Kohl and Genscher. "Let's not fight (any longer)", says Lubbers, 'would constitute a more accurate interpretation'. ${ }^{61}$ The most obvious consequence would have been that German Chancellor Kohl could pursue recognition in the knowledge that this was supported, or no longer opposed, by at least half of the EC government-leaders.

Even to governments that were not part of the EPP consensus, it was obvious from Germany's public statements in early December that it would insist on a decision on recognition before Christmas. On December 4, Genscher spoke to the WEU assembly and declared that the EC 
Presidency had set a deadline of December 10. This was a reminder of how seriously Germany had taken the deadline set by Van den Broek and how important a factor it had been in tying Germany into the EC's diplomacy. There were numerous other public and private indications of Germany's resilience, such as a statement by a German government spokesman on December 13. Asked by journalists whether Germany would recognise Croatia and Slovenia (the other republics were not mentioned) before Christmas, the spokesman answered: 'Together with as many other countries as possible within the framework of the EC.... On December 16 the Foreign Ministers of the EC will discuss this issue. We will in any case wait for that.'

The German self-assuredness prior to the final debate seemed justified. The last vestiges of potential opposition from other EC member states had been cleared at the Intergovernmental Conference of Maastricht on December 9 and 10. In Maastricht, Germany supported Britain on a number of crucial points, including an opt-out of the TEU's social chapter. As a consequence, the British, who still had great doubts about the timeliness of recognition, seem to have felt a sense of obligation to Germany that made it hard to oppose Germany on the matter of recognition. ${ }^{62}$ With British opposition silenced, France also gave way. To avoid potential humiliation the French devised a formula, which they hoped would cover France if the EC went ahead with recognition. This formula consisted of a number of general criteria for recognition of new states in Eastern Europe and the Soviet Union. If the EC and its member states would go ahead with recognition, then they would do so on the basis of criteria which the French could claim to have formulated.

The outcome seemed so certain that the Dutch Presidency on December 12 distributed a telegram among the Twelve, proposing that recognition should be the decision taken at the ministerial meeting of December 16: '[T]he Twelve should consider to proceed with a policy of conditional recognition. This would imply granting recognition only to republics that have accepted EC proposals.' Shortly before the meeting on December 16, France gave in completely, turning its criteria-formula into a joint French-German proposal.

Despite the apparently justified German self-assuredness, the Dutch Presidency went into the final debate with reservations about the policy it 
had supported for the past two months. The main reason was that the Dutch had belatedly realised that their anti-Serbian selectiveness contained one crucial omission: the consequences of recognition for BosniaHerzegovina. All this time the discussion about recognition had really been about Croatian and Slovenian independence. The initial concern about Bosnia-Herzegovina had slipped into the background as the Presidency's time was taken up by different considerations, despite regular reminders from the Embassy in Belgrade that Bosnia's stability was gradually being eroded. Warnings from Lord Carrington, UN Secretary General Javier Perez de Cuellar, UN mediator Cyrus Vance and US President George Bush about the consequences of a recognition in the absence of a general settlement had served as unwelcome reminders of the dangers associated with a selective approach that was not backed up by some kind of military force. When on December 15 the Security Council adopted resolution 724, the Dutch Presidency began to feel even more uncomfortable with its own position. Resolution 724 called upon all states and parties 'to refrain from any action which might contribute to increasing tension, to inhibiting the establishment of an effective cease-fire and to impeding or delaying a peaceful and negotiated outcome to the conflict in Yugoslavia.' Clearly, in their eagerness to maintain the EC's cohesion, to keep Germany on board and have an outcome before Christmas, the Dutch had ceased to pay sufficient attention to a problem whose seriousness they had been acutely aware of in earlier phases.

As a result of these fresh concerns, Van den Broek entered the ministerial meeting of December 16 'with reservations about recognition. ${ }^{63}$ Eventually, Van den Broek went along with what was now the German-French compromise 'because we could not allow the Serbs to go on as they liked. ${ }^{64}$ But before that happened, Van den Broek had instructed Van Walsum to see if he could get the political directors to achieve a consensus on the basis of non-recognition and isolate Germany. Surprisingly, Van Walsum succeeded in doing so, the reason being that the great majority of political directors agreed that 'the effect of the recognition of Croatia on the precarious peace in Bosnia should outweigh the unity of the Twelve'. But when Van Walsum reported the outcome of the meeting to Van den Broek, the latter was not as pleased as Van Walsum had expected. Instead, an agonising Van den Broek indicated that it was 'a complex issue and that recognition was inevitable.' ${ }^{65}$ The Italian, Danish and Belgian Foreign Ministers had immediately overruled their political directors and 
indicated that their countries were prepared to go a long way to keep Germany within the consensus of the Twelve, with De Michelis in particular expressing the need to maintain the unity of the EC. Moreover, when Britain, Portugal, the Netherlands, Spain, Ireland and Greece indicated that they were concerned about the consequences of an early recognition, Germany, supported by Denmark, Belgium and Italy, refused to postpone recognition any longer. France, moreover, pointed out that a reasonable compromise-proposal, the French-German criteria, lay on the table, which would enable the EC to paper over the existing divisions. German Foreign Minister Genscher hinted more than once that his country had accommodated others at Maastricht and that the German government could not renege on its public commitment to a recognition before Christmas. Open division was the last thing Van den Broek needed. According to Van Walsum, this 'would look bad on the Dutch Presidency. Van den Broek then turned the meeting around and a compromise was sought on the basis of the French formula.' ${ }^{66}$

The decision eventually reached in the morning of December 17 was that those republics that wished to be recognised as independent states would have to apply for recognition no later than December 23. Recognition would then take place on January 15, 1992. In order to be eligible for recognition by the EC and its member states, these republics would have to fulfill a number of criteria laid out in the EC ministerial declaration of December 16. It would be for the arbitration commission, whose origins lay in the French-German initiative of August 27/28, to judge whether the republics fulfilled the criteria. The republics would have to respect the CSCE and UN principles of international law, such as the inviolability of borders, human rights, the rights of minorities and the non-proliferation of nuclear weapons. Also they had to accept Lord Carrington's proposals for a special status for certain areas and to oblige themselves to search for a peaceful solution of the conflict, if necessary through arbitration.

In a final twist to the debate, Germany and Italy indicated that they did not regard themselves bound to a negative judgment from the arbitration commission regarding the fulfillment of criteria. This meant that Germany, despite having co-sponsored the creation of an arbitration commission and the establishment of criteria, reserved the right to recognise Croatia and Slovenia (the only two republics that seemed to matter to 
Germany in this context) in spite of a possible negative judgment from the arbitration commission. Germany was apparently concerned that France might use the arbitration commission, which was chaired by Robert Badinter, an eminent French judge and former justice Minister, as a block against recognition. In the end, the German government kept its promise to German, Croatian and Slovenian public opinion and announced its decision to recognise Croatia and Slovenia on December 18, before the arbitration commission had been able to pass judgement.

\section{Conclusion}

The Dutch EC Presidency of 1991 was an influential player in the European diplomatic effort regarding the Yugoslav crisis. In some cases, such as the negotiations in Brioni in July, the launch of the EC Monitoring Mission or the blocking of a French proposal to launch a military intervention under the auspices of the Western European Union (WEU), the Dutch Presidency played a crucial role. What is more, the Netherlands during this period successfully protected its own interests. The most satisfying result in this regard was that the Dutch were successful in maintaining and presenting a basic degree of unity between the EC member states, despite the underlying divisions. Initially, the Netherlands achieved this by resisting pressure from Germany and a few other countries to recognise individual Yugoslav republics in the absence of a negotiated settlement when a majority of member states still favoured pursuing such a settlement. Later, when Dutch views hardened and became more antiSerbian, the Presidency constituted an important factor in steering the remainder of the EC member states towards the pro-recognition line.

Clearly, the decision of December 16 and 17 was the most important political decision taken in the context of the international community's diplomacy with regard to the Yugoslav crisis between July and December 1991. The circumstances in which the decision was taken, the players involved and the goals it was meant to serve, tell us three things about the environment in which the Netherlands operated during the second half of 1991. First of all, that environment was marked by an absence of the United States. Following the Dutch Presidency's attempt of July 2 and 3 to engage the United States in the management of the Yugoslav crisis, America remained aloof. Rather than formulating and implementing a joint approach, American policy makers in their contacts with The Hague 
restricted themselves to irregularly expressing their concern or support for European policies or else to give advice. Partly because of the American distance from the issue, the main platform for international diplomacy constituted the EC; an elaborate international regime with shared norms, rules and decision-making procedures. In a regime-dominated environment, a smaller state should theoretically be better placed to exert influence on international affairs than in an adversarial, multi-polar environment. Thirdly, by the end of 1991, the Yugoslav crisis, having continually risen in importance on the international political agenda, became the litmus test of Europe's ability to pursue common foreign policies. In retrospect, the collective decision making of December 1991 constituted both the high-point of European efforts to approach the crisis jointly and the end of the European road. Lacking a credible military capability, recognition was the most important card the EC member states possessed but once played, there remained little else with which to influence events on the ground.

When we consider the position of the Netherlands in its environment, clearly the country was well placed to exercise power. This was to an important degree the result of 'position power'. As the EC Presidency, the Netherlands stood at the centre of most European attempts to formulate and implement common policies, with the exception of bilateral FrenchGerman initiatives, which were usually prepared outside the formal structures of European Political Cooperation. Nevertheless, as EC Presidency, the Netherlands was responsible for presenting a common stance, was relatively well informed about the national positions of its EC partners and, as a result was well placed to initiate or give direction to common European approaches.

The evidence suggests that the Netherlands exploited the possibilities associated with the Presidency to considerable effect on a number of occasions during the second half of 1991. Apart from exercising negative power, such as when resisting German pressure for an early recognition and the French idea of a WEU-force, the Dutch used their positionpower in a more creative fashion as well. The most important occasion in this respect was the imposition of a two-month deadline on the parties to the EC-chaired negotiations for a general settlement. By making it inevitable that a decision on recognition would have to be taken before the end of the Dutch Presidency, the Netherlands was able to contain 
German pro-recognition pressure and prevent a German 'Alleingang'. At the same time, by keeping open the theoretical possibility of a settlement the Dutch could not be accused of undermining the EC Conference even though this was the practical effect of the deadline. The obligation now lay with the supporters of a negotiated settlement to explain how this could be reached and, if they were forced to admit it could not, why one should postpone recognition any longer. The warning of a spill-over of the conflict to Bosnia-Herzegovina by Lord Carrington and others seems to have created some doubt in The Hague about the effectiveness of the selective approach. But by then the path to recognition had been so firmly laid down that there was no way back. Moreover, Van den Broek and his officials believed that their main argument in favour of recognition, namely the need for a response to Serbia's fait-accompli policy, was still valid. Moreover, by showing himself to be concerned about the situation in Bosnia-Herzegovina during the meeting of December 16 and 17, Van den Broek ensured that he could not later be accused of having underestimated the potential for spill-over. All subsequent criticisms of the EC's handling of the recognition issue could be passed on to Germany, whose ruthless pursuit of Croatian and Slovenian recognition had been plain for everyone to see.

External factors, particularly the Netherlands' position-power, were key to Dutch influence during the second half of 1991. Domestic factors nevertheless also facilitated the exercise of power in Dutch foreign policy. In contrast to the earlier period, there was a strong desire for action in the Dutch foreign policy establishment. However, in contrast to later episodes, the policies geared to the Yugoslav crisis generally remained firmly tied into the all-important, explicitly stated, national interest of maintaining EC cohesion. The Dutch interest in EC cohesion, itself admittedly influenced by Dutch values, principles and views regarding European integration, functioned as a constant and an 'objective' national interest in the framework of the Yugoslav crisis. That said, it is clear that the fall of Vukovar and the shelling of Dubrovnik triggered a response that was far more emotional than anything seen until that moment. The Dutch dropped all pretense of supporting the idea of a negotiated settlement, thus risking opposition, when a continuation of the 'calculated' selectiveness would almost certainly have led to the desired outcome anyway. 
1 Interview Ter Beek.

2 Leonard Ornstein, 'Het stratego van de experts', Vrij Nederland, October 31, 1992, p. 12.

3 Silber and Little, The Death of Yugoslavia, p. 178.

4 Interview Van Walsum.

5 For an example of Van den Broek's usual attentiveness to American views, see: Willem van Eekelen, Debating European Security, 1948-1998 (The Hague/Brussels: Sdu Publishers / Centre for European Policy Studies, 1998), p.78.

6 International Herald Tribune, July 5,1991.

7 Meier, Wie Jugoslawien verspielt wurde, p. 390.

8 Gow, Triumph, p. 52

9 Interview Van den Broek.

10 Silber and Little, p. 165.

11 On June 17, for instance, the Embassy had warned the then Luxembourg Presidency that 'in the trilateral discussions between Tudjman, Milosevic, and Izetbegovic, the spectre of trilateral division of the Bosnian administration... into two Serbian cantons, two Croatian cantons and two Muslim cantons was raised in the margins of the meeting and in the Serbian press, to the deep dismay and anger of Mr. Izetbegovic.'

12 Interview Van Walsum.

13 Ibid.

14 Interviews Van Walsum, Van den Broek.

15 Some two-thirds of the telegram were published in: Owen, Balkan Odyssey, pp. 31-33.

16 Quoted in: Huys, In opdracht van Hare Majesteit, p. 23.

17 Interview Van Walsum.

18 Michael Libal, Limits of Persuasion (New York: Praeger, 1998), pp. 129-135. See also: Immo Stabreit: 'Yugoslav Breakup: Don't Blame Germany', Washington Post, June 29, 1993.

19 Interview Van den Broek.

20 Interview Van Walsum.

21 Ibid.

22 Vrij Nederland, October 31, 1992, p. 13.

23 Interview Hazewinkel.

24 Van Eekelen, Debating European Security, p. 143.

25 Ibid., p. 143.

26 The Independent, 26 July 1991. 
27 Hans-Dietrich Genscher, Erinnerungen (Berlin: Siedler Verlag, 1995), p. 943.

28 Interview Hazewinkel.

29 Henry Wijnaendts, Joegoslavische Kroniek Juli 1991 - Augustus 1992, (Amsterdam: Rap, 1993).

30 Interview Van Walsum.

31 Interview Van den Broek.

32 Genscher, Erinnerungen, p. 946.

33 Interviews Van den Broek, Van Walsum.

34 Interview Van Walsum.

35 Hans-Heinrich Wrede, “"Friendly Concern” - Europe's Decision-making on the Recognition of Croatia and Slovenia', The Oxford International Review, Vol. IV, No.2, Spring Issue 1993, p. 31.

36 Meier, p. 400.

37 Quoted in: Van Eekelen, p. 28.

38 Interview Kreemers.

39 Cees van Lotringen, De kwetsbare kolos, de gevaren van een zwak Duitsland (The vulnerable colossus, the dangers of a weak Germany) (Amsterdam/Antwerpen: Veen, 1995).

40 Wijnaendts, Kroniek, pp. 101-102.

41 Wijnaendts, Kroniek, p. 108.

42 Cf. Van Eekelen, p. 145.

43 New York Times, September 17, 1991.

44 Meier, Wie Jugoslawien verspield wurde, p. 401

45 Interview Van den Broek.

46 No mention is made of the October 10 deadline by Cohen, Gow, Libal, Meier, Silber and Little, Woodward or Wrede. Even Wijnaendts completely ignores it, despite having introduced the deadline to the EC Conference's staff.

47 Cf. Van Hulten, The Short Life and Death of the Dutch Draft Treaty towards European Union; Rozemond, De gang naar Maastricht; Tiedeman, Elsevier June 22, 1996.

48 Interview Ambassador Niek Biegman, The Hague, August 23, 1995.

49 Rob Meines, 'Succes voor shuttlediplomatie Den Haag' (Success for shuttle diplomacy The Hague), NRC-Handelsblad, October 10, 1991.

50 Letter from Lord Carrington to the author, December 9, 1996.

51 Interview Van den Broek

52 News report from Dutch Press Agency ANP, 256 BUI 108 ANP - 1817, October $10,1991$.

53 Henry Wijnaendts, Memorandum no. 5, October 10, 1991, Situation Report. Document of the EC Peace Conference, in possession of author. 
54 Helmut Hetzel, 'In zwei Monaten entscheiden wir über die Anerkennung. Slowenien und Kroatien: EG-Ratspräsident Van den Broek konkretisiert im “Presse”-Gespräch das letzte Ultimatum', Die Presse, October 18, 1991.

55 Vrij Nederland, October 31, 1992, pp. 12-13.

56 Ibid.

57 Interviews Van den Broek, Van Walsum.

58 A second private Christian-Democrat meeting was held in the Foreign Ministry in The Hague on December 6. See: Frits Schaling, 'Christen-democratisch beraad over Euro-top' (Christian-democrat council on Euro-summit), NRCHandelsblad, November 27, 1991; Tom Walker, 'Germany steps up pressure for union', The Times, November 27, 1991, and; Ian Glover-James, 'Powerful Kohl club closes the door on Britain, Sunday Times, December 8, 1991.

59 Interview Van den Broek.

60 Interview Ter Beek.

61 Letters from Prof. Ruud Lubbers to the author, February 27, 1997; July 7, 2000.

62 John Newhouse, 'The Diplomatic Round. Dodging the Problem', The New Yorker, August 24, 1992, pp. 65-66. Also: 'Failure in Yugoslavia. The high cost of peacekeeping', The Independent, November 1,1993.

63 Interview Van den Broek.

64 Ibid.

65 Interview Van Walsum.

66 Ibid. 



\section{Moral and Political Entrapment \\ The Netherlands and International Peace Plans for Bosnia, 1992-1994.}

In 1992 Bosnia-Herzegovina became the scene of the next, most violent phase in the Yugoslav crisis. In late March of that year, the Serbian campaign began in earnest. Within the space of little more than two weeks all the cities commanding the roads between Bosnia and Serbia as well as between Bosnia and Serb-held Croatia were taken by Serb forces and emptied of its Bosnian Muslim or Croat population. Subsequently, the roads between these towns were opened up. By May, some six weeks after the start of the campaign, Serb forces controlled some 60 per cent (ultimately 70 per cent) of the territory of Bosnia-Herzegovina, even though Serbs constituted only 31 per cent of the population of Bosnia-Herzegovina. ${ }^{1}$ Within the territory taken by Serb forces, thousands of Muslims in particular were murdered and imprisoned, while hundreds of thousands more were driven from their homes in a strategy that became known as 'ethnic cleansing. In Eastern Bosnia the towns of Srebrenica, Zepa and Gorazde had somehow withstood the attacks and had been able to organise a Yugoslav-style territorial defence successfully. By the end of the year, the Bosnian Muslim forces from Zepa en Srebrenica, as well as some smaller enclaves to the north of Srebrenica had been able to link up with each other, connecting the isolated enclaves into one swath of territory - having killed hundreds of Serbs in the process. However, isolated from Bosnian Muslim-held central Bosnia, the resistance of these enclaves withered away, so that by March 1993 it looked as if Srebrenica would fall too. This was when the UNPROFOR Commander, French General Philippe Morillon intervened personally and went into the Srebrenica enclave to share 
the population's plight and stave off further attacks. The UN Security Council subsequently declared Srebrenica a 'safe area'. A cease-fire agreement was reached between the Bosnian Serb commander, General Ratko Mladic, and the commander of the Bosnian government's forces, General Sefer Halilovic. Canadian peacekeepers were placed inside the 'safe area' in order to deter attacks against it. The Canadians were replaced by Dutch peacekeepers in early 1994.

During the first two years of the Bosnian war, from April 1992 until late 1993, the 'selectiveness' that had started to emerge during the Dutch term as EC Presidency gradually intensified. The general aim of Dutch selectiveness was to defend law and order in the former Yugoslavia, particularly in the now officially recognised republic of Bosnia-Herzegovina. When war erupted in Bosnia-Herzegovina in May 1992, on a scale not seen in Croatia, this concern translated itself into three related - though not always easily reconcilable - policy aims. The first was to preserve or restore as much as possible the territorial integrity of Bosnia-Herzegovina against what was seen as external aggression by Serbia and the Yugoslav army. The second was to defend democracy and human rights against the Serbian strategy of ethnic cleansing. The third was to relieve the suffering of the civilian (Muslim) population. These three goals had in common the apparent need for a political and military intervention in support of the legitimate Muslim-dominated government of BosniaHerzegovina. ${ }^{2}$

We will endeavour here to trace the beginning of the Dutch road into entrapment. We will demonstrate how in August 1992, leading Dutch politicians applied high moral rhetoric to mark their positions domestically and internationally. Secondly, having occupied the moral highground so visibly, the Dutch government became a loyal supporter of the legitimate Bosnian government. This meant backing up demands posed by the Bosnian government and maintaining a principled opposition to peace initiatives and policies that did not seem to deliver these demands. Nor could settlements be supported that did not fulfil the moral criteria which the international community had formulated, but to which the Netherlands clung more tightly than most other Western governments. By the time it was realised that the Netherlands risked isolation, it was too late to backtrack, given that the domestic audience had been fed the moral diet on a daily basis and would not have been able to stomach an 
abrupt change of message. What is more, the Dutch troop commitment to the UN's safe area policy had already been made.

\section{Moral Entrapment}

Following the end of the Dutch Presidency, the Dutch Foreign Ministry continued its selectiveness. Van den Broek and his officials stuck to their analysis that Serbia and the Yugoslav army were the main culprits in the Yugoslav crisis. Hence, the Netherlands disagreed with suggestions from a small number of EC member states and UN officials to suspend the EC's decision to recognise Bosnia in order to forestall a VJ-backed secession by the Bosnian Serbs. Van den Broek opposed this reasoning, arguing instead that 'Serbia should not be rewarded for its policy of faits-accomplis and for effectively holding Bosnia-Herzegovina hostage, by withholding recognition from that republic if it fulfilled the criteria.' Indeed, as Van den Broek had added, the crucial question was whether Milosevic would be prepared to respect Bosnia's borders; if not, then the situation in Bosnia would escalate regardless of whether the EC recognised Bosnia or not. The USA and a majority of EC member states shared the Dutch position regarding Bosnia's recognition.

When war broke out in Bosnia in early May, Dutch officials and Minister Van den Broek could not help feeling vindicated in their analysis. They had since December 1991 supported the Bosnian government's calls for a preventive deployment of UN peacekeepers in that republic. During the public hearings of the TCBU Parliamentary investigation committee in May and June 2000, Van den Broek reflected on the explicit interventionist stance he took up after the Dutch EC Presidency had ended its term. The Netherlands had been among the vanguard of countries that wanted a forceful intervention in Bosnia-Herzegovina in 1992. Van den Broek solemnly declared: 'I am not ashamed to say that I have always been a supporter of military intervention... The Netherlands has a moral duty to contribute to the maintenance of the international legal order.' ${ }^{3}$

What really engaged the Dutch, as well as Western, moral consciousness, were the TV images of Serb-run concentration camps full of emaciated non-Serb prisoners. ITN's television production of August 6, 1992 triggered the kind of response that neither written journalism, nor the siege and fall of Vukovar, nor events in Bosnia until then had provoked. 
Analogies with the German concentration camps of the Second World War were too obvious to be ignored: 'The main objective of the concentration camps, especially Omarska but also Keraterm, a UN report later concluded, 'seems to have been to eliminate the non-Serbian leadership.'4 Like in Britain, France or the US, many Dutch commentators now argued the case for a military intervention against the Serbs, who were embarking on a project akin, in nature if not in scale, to what the Nazis had done between 1939 and 1945.

Virtually the entire Dutch political establishment adopted the case for a military intervention in support of the Bosnian Muslims as their own. But, in contrast to their counterparts in France and Britain, Dutch politicians showed little interest in, and were even dismissive about, such practical questions as how the Bosnian Muslims could best be helped politically and militarily, who would carry out a military intervention, or what the political outcome of a military intervention ought to be. The whole debate on intervention was conducted on a moral level and left no room for practical considerations. The general attitude was very much that the Bosnian government needed to be supported and that as a politician, journalist or diplomat it was vital to be seen to be supportive of the Bosnian government, simply because it was the morally right - and the politically correct - thing to do.

Following the discovery of the camps, the Dutch Minister for Development Cooperation, PvdA politician Jan Pronk, made it clear that in his view the war in Bosnia was of a different nature than the one that had led to the destruction of Vukovar: 'Pure racist violence on a large scale, you cannot let that pass. Because of the attempt of the Serbs to exterminate minorities, the character of the conflict in Yugoslavia has changed. Now that this Hitlerian strategy is evident, military intervention must take place. 5

Pronk was not just $a$ Minister. He was one of the most prominent and outspoken politicians in the Netherlands with a vocal band of supporters in the PvdA (Labour), the largest political party at this stage. More than any other politician in the Netherlands Pronk embodied the 'ethical impulse' in Dutch foreign policy. Strongly supported by a substantial portion of the PvdA electorate, Pronk's opinions were always noted and could strongly influence opinion within his party. In this case he had also 
touched a nerve in the Dutch population at large. Only a small minority of commentators voiced their doubts about the new-born interventionism on the part of a political class that had hitherto not been known for its enthusiasm and knowledge about military matters. Thus, Jerôme Heldring wrote in NRC Handelsblad that Pronk was too nonchalant about the nature of the military intervention he advocated. It was not done for a Cabinet Minister to argue away the complexities of military intervention by stating that 'as an amateur', he did not know 'how one

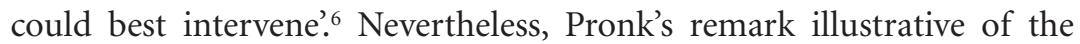
thinking of most of his colleagues, irrespective of their political background. When the terrible news from Bosnia reached them, they abandoned their summer holidays for a special session of Parliament to discuss what should be done. In the run-up to the debate, the media were replete with calls for action, such as by CDA (Christian-Democrat) parliamentary spokesman for Foreign Affairs Jaap de Hoop Scheffer, who said: 'I think that has to happen, military intervention. You have to ask yourself for a moment in which way. You must intervene militarily.' Another leading figure in the Dutch foreign policy establishment was Joris Voorhoeve, former parliamentary leader of the VVD (Conservative Liberals), who was at that time the head of the international relations think-tank 'Clingendael' and later became the Minister of Defence. In an open editorial Voorhoeve and his colleague Theo van den Doel wrote: '... if humanitarian law does not compel us to an active combating of genocide, then certainly ethics compels us to take action against mass murder, torture, starvation and expulsion. For Evil to be victorious the only requirement is for good people to do nothing. In that sense the outside world becomes co-responsible for the mass murders in Bosnia.'

These are but a few of an endless series of public statements testifying to the moral indignation felt by Dutch politicians upon learning the true scale of the atrocities being committed in the Bosnian war by Serb forces. Dutch politicians were by no means isolated from Dutch public opinion as expressed in the media. Editorials, television interviews, opinion polls, parliamentary debates and the advice emanating from the officials in the Foreign Ministry all pointed in the same direction: giving moral, political and military support to the Bosnian Muslims. ${ }^{9}$ Together with the very few columnists such as Heldring, the main voice of dissent was that of the Ministry of Defence, which warned that the kinds of military steps being discussed in Parliament and in the press would not be easy to carry out in 
practice and that, in any case, the means at the disposal of the army at a time of reforms were limited (see chapter 5).

\section{The Netherlands at the 1992 London Conference}

It was in this heavy atmosphere that Foreign Minister Hans van den Broek led a Dutch delegation to the London Conference of August 26-27, 1992. The Conference was hosted by the British EC Presidency and brought together the EC and the UN in what British Prime Minister John Major called a 'major effort to mobilise international pressure on all the former Yugoslav parties and in particular the Serbs to abandon their wholly unacceptable use of force.'10 Only a week before, the UN Security Council had passed Resolution 770, which empowered states, 'acting nationally or through regional arrangements, to use any measures necessary to deliver humanitarian relief'. From the Dutch point of view the time was right and the Conference the perfect forum to mobilise international public opinion for the selective approach the Dutch had themselves adopted almost a year ago.

The Dutch delegation arrived in London in a purposeful mood. Employing classic small-state tools, the Netherlands sought both to mobilise international public opinion in support of the Bosnian government and to enhance its reputation as a haven of moral virtue. Using a mixture of demonstration politics, moral guidance and public criticism the Dutch delegation tried to exert influence on the direction of international Yugoslavia diplomacy. At the same time there was an element of selfcongratulation in the Dutch delegation's approach to the Conference, as was later admitted by one member of the delegation. According to the Foreign Ministry's director for UN Affairs, Jan Hoekema, the delegation members felt as if they were on a mission to convert the international community: 'In London, salvation and blessing would have to come from ourselves. ${ }^{11}$ Using 'clear language', the Dutch would try to push the international community into taking sides with the Bosnians against the Serbs.

Van den Broek's speech at the Conference did achieve international fame, often being mentioned in the literature as one of the Conference's toughest. ${ }^{12}$ In it he stated: 'The most important aim of this conference in London, in our view, is therefore to increase the pressure on the chief culprit, Serbia, 
with its abhorrent practice of ethnic cleansing. He reminded the participants of the principles, such as respect for borders and human rights, which were under threat and called for the full and immediate implementation of UN Security Council resolution 770 . He went on to propose a number of tough measures against Serbia, fully in line with Dutch selectiveness, such as the admission of observers in a number of places in the former Yugoslavia, notably in Serbia's Albanian-inhabited province of Kosovo, a tightening of the trade embargo, the expulsion of Serbian representatives from official bodies and the setting up of a war crimes tribunal. Having made references to the need to protect human rights, recognise borders and the rights of minorities, Van den Broek went further: 'I said that "military intervention must not be excluded as a last resort". That was something my officials were not allowed to write. ${ }^{13}$ According to Silber and Little, Van den Broek's statement formed the basis for a declaration 'lambasting the Serbs', which the Netherlands and Bosnia-Herzegovina insisted should be adopted by the Conference, or else they would walk out of the Conference together. ${ }^{14}$ Eventually, most of the Dutch-proposed elements were indeed taken up in the various statements issued by the Conference. The most important of these were the 'Programme of Action on Humanitarian Issues Agreed Between the Co-Chairmen to the Conference and the Parties to the Conflict', a 'Statement of Principles', the 'Work Programme of the Conference' [which set up the International Conference on the Former Yugoslavia], 'Specific Decisions by the London Conference' and a 'Statement on Bosnia.' ${ }^{15}$

In particular the 'Statement of Principles' would often be cited by the Dutch government in months to come as the yardstick by which to measure the moral and political acceptability of the plans on the table. Indeed, there were thirteen principles a peace plan should adhere to, the most important of which were the non-recognition of all advantages gained by force, the respect for human rights and fundamental freedoms of the members of ethnic and national communities, compliance with the Geneva Conventions and the fundamental respect for the independence, sovereignty and integrity of state borders. ${ }^{16}$

For the Netherlands, the London Conference constituted a diplomatic triumph, albeit a short-lived one. The problem with the Dutch position was not that it was wrong - in retrospect it may be said to have been very right - but that it presumed a willingness to make sacrifices on the part of 
those countries who would be instrumental in turning principle into reality. Van den Broek later recalled receiving a hand-written note from Major immediately after his speech, which read: 'Hans, I agree with every word you said', adding that he wished he still possessed it. ${ }^{17}$ That last remark indicated that Van den Broek felt that Major had backtracked on these words after the Conference. Whether or not this was a fair judgement to make, clearly the words produced by the London Conference meant little by themselves. They required practical measures for them to be given real weight. But the Dutch hope that more powerful countries might launch a military intervention was soon proven to be false. 'Those framing policy felt unable to undertake more decisive military action both for practical reasons and because of the limits imposed by both the UN Charter and the conventions of international relations. ${ }^{38}$ The intervention eventually launched was of a strictly humanitarian nature and consisted of the provision of military escorts to the humanitarian operation carried out by the UN High Commissioner for Refugees.

For the Dutch Foreign Minister and his officials, the weak follow-up to the London Conference was hard to swallow. The Netherlands now entered into a state of self-righteousness that was as understandable as it was dangerous for a country that lacks the political and military power to turn high moral principles into concrete action. Believing the case for intervention to be crystal-clear from a moral point of view, the Dutch Foreign Ministry refused any longer to try and understand, let alone respect, the reasons why the countries that would have to ensure compliance by the Yugoslav parties to the London decisions were reluctant to pay the military costs associated with this kind of coercion. To Van den Broek and his officials 'the British were appeasers, the French pro-Serb' and the refusal to intervene militarily was a matter of 'weak knees.' ${ }^{19}$ Dutch officials, politicians and journalists frequently made similar remarks. Some of this contempt inevitably showed through in contacts with European counterparts and, inevitably, the moral pride of the Dutch was registered outside the country. (Interestingly, in June 1993 the French permanent representative to the UN in New York remarked that France had 6,300 troops on the ground and 'would not accept lessons in morality from anyone.' ${ }^{20}$ ) In essence, in studying Dutch policy between August 1992 and May 1993, one is studying the behaviour, not of a government, but of a single-issue pressure group. ${ }^{21}$ For months, an ever more frustrated Dutch government continually advocated policies that were morally 
righteous but whose implementation would not be a Dutch responsibility. At some point, Dutch policy makers would inevitably begin to feel uncomfortable with this position. They would then be faced with a difficult choice: either they would have to moderate a message they themselves and Dutch public opinion claimed strongly to believe in, or they would have to take on a considerable share of the burden for implementing the policies they were advocating. While the entrapment of 1994-1995 was still far from inevitable, its contours had slowly begun to take shape.

\section{Political Entrapment}

\section{The Vance-Owen Peace Plan}

The Vance-Owen Peace Plan (VOPP) had been drawn up in late 1992 by the International Conference on the Former Yugoslavia (ICFY) under the chairmanship of Cyrus Vance and David Lord Owen. A crucial role in the actual drafting of the plan had been played by Martti Ahtisaari, the later Finnish president and international mediator for the Kosovo-crisis. The ICFY had drawn up various options, all of which needed to reconcile the tension between the stated wish of the international community and the Bosnian government to retain a single, multi-cultural Bosnian state with a central government on the one hand and military reality, pre-war demographics and the desire on the part of the Bosnian Serbs and the Bosnian Croats to obtain at the very least a high degree of autonomy on the other. Eventually, the ICFY co-chairmen had opted for a de-centralised state of ten provinces. These provinces would inevitably have an ethnic majority but all were constitutionally designed to be multi-cultural, while none would have international-legal status, so as to prevent the tripartition of the country and allow as many refugees as possible to return to their homes. ${ }^{22}$ The plan was presented on January 2, 1993 in the first of a series of plenary sessions comprising the political leaders of all three sides. At the end of the two-day session the Bosnian Croats signed the package, consisting of the constitutional principles, the cessation of hostilities agreement and the map, in full. Within the following two weeks the Bosnian Muslims signed the constitutional principles and the cessation of hostilities but refused to accept the map. The Bosnian Serbs, who were being asked to give up some 38 per cent of the 60 to 70 per cent of territory they controlled in Bosnia-Herzegovina, signed the cessation of hostilities but refused to sign anything else. ${ }^{23}$ Eventually, the Bosnian Serb delegation headed by Radovan Karadzic signed the package in full on 
May 2 but that success proved short-lived as the validity of the signature was called into question by a referendum among the Bosnian Serbs, who rejected the plan. The US, Britain and France could have decided to start implementing the plan on the basis of the Bosnian Serb delegation's signature of May 2 but refused to do so for fear of continued Bosnian Serb opposition.

Owen later accused the Netherlands of not having given its full support to the VOPP in the first months of 1993 and that of all the EU member states the Netherlands had been the most critical. ${ }^{24} \mathrm{He}$ also argued that the Netherlands had 'created very large problems for the Vance-Owen peace plan', had influenced 'some attitudes' of the first Clinton administration - which had refused to support the plan - and that 'the Netherlands played an important role in the torpedoing of the Vance-Owen plan'. These remarks were greeted in the Dutch newspaper editorials with an uneasy, somewhat bemused disbelief, perhaps because it challenged the comforting self-image of the Netherlands as a morally righteous and influential state, whose fault, however, it ultimately never was due to its limited power. Also, the idea that 'raw emotions', 'ignorance' and 'pseudomoralism' had been the main domestic sources of Dutch opposition to the plan was dismissed..$^{25}$

One prominent Dutch politician was stirred into denying Owen's criticisms. Hans van den Broek, who had left his post as Minister of Foreign Affairs in January 1993, to become the EU Commissioner for External Affairs, let it be known through his spokesman in Brussels, that he 'did not remember the Dutch role this way. ${ }^{26}$ That it was Van den Broek who replied to Owen's accusations seemed a bit strange, given that he had left the Dutch Cabinet on January 2, 1993. While the peace package had gradually developed during the preceding months, the official negotiations had not started until that same day. In other words, the responsibility for formulating Dutch policy regarding the Vance Owen plan fell primarily on the shoulders of Van den Broek's successor rather than on Van den Broek himself. It is unclear what motivated Van den Broek to respond in this manner, but his continued sense of responsibility for Dutch policy even after his departure from The Hague reflected the continuity of the 'selective' approach of which Van den Broek had been the political architect. 
The only apparent discontinuity between Van den Broek and his successor, Professor Pieter Kooijmans, an eminent lawyer from the University of Leiden who later became a judge at the International Court of Justice, was that the latter had no problem admitting that he had opposed the VanceOwen Peace Plan. According to Kooijmans, 'The Netherlands was very critical towards the VOPP.27 Senior diplomats confirmed that they too had had serious objections to the plan. According to Hoekema, for instance, he and his colleagues had shared a sense of 'moral indignation', had been 'very critical' of the VOPP and had entertained 'whole series of objections' against it. ${ }^{28}$ Dr Niek Biegman, who had become the Permanent Representative at the United Nations in New York in September 1992 following a spell as Director-General for international cooperation, also acknowledged that the Netherlands had been critical towards the VOPP. ${ }^{29}$ Ambassador Wijnaendts, who had returned to his post in Paris, posed a critical question, in his case publicly and at a time when the VOPP was still on the table: 'Was it... wise' he wrote in his own memoirs, 'on the part of Vance and Owen to want to impose a plan for the division of BosniaHerzegovina on the Muslims, the main victims of the conflict?'30

There were two major reasons why the Netherlands opposed the VOPP: it was considered unjust and it was thought that a better alternative could be had. The plan was perceived to reward the Serbs for their ethnic cleansing campaign by awarding them too much territory. The Bosnian Muslims, the chief victims of the war, were felt to be hard done by. Secondly, it was hoped that something better could in practice be achieved. 'We considered the VOPP a post-facto legitimisation of ethnic cleansing and it conflicted with the principles of the London Conference. We did not believe in a durable peace that did not contain the basic elements of justice... The Bosnians opposed it and you have to listen to those who have to live with it. We were in close contact with them. ${ }^{31}$ In sum, according to Kooijmans, the VOPP entailed a 'premature capitulation before ethnic cleansing. ${ }^{32}$ Biegman too acknowledged that the Dutch had found it difficult to reconcile their own principled stance with support for the VOPP, saying that the plan had 'contained too great an element of rewarding Serbian aggression. ${ }^{33}$

The main objections raised by the Dutch to the Vance-Owen plan were thus of a moral nature, although it was also sometimes argued that the plan was difficult to implement. It is, in retrospect, difficult to raise 
principled objections against the intentions accompanying the Dutch position. Nevertheless, objections can be raised regarding the attitude underlying the Dutch stance and the lack of attention paid to the possible effects of the Dutch position for the situation on the ground in Bosnia. One of the problems with the Dutch position was an underlying attitude of moral arrogance. The Dutch professed to be frustrated by the fact that theirs was a minority stance but at the same time they seemed somehow to revel in it because it confirmed the home-made image of their country as a haven of moral virtue. ${ }^{34}$ Kooijmans, for instance, argued: 'We made a clearer distinction between good and bad than most of the others ... that was perhaps our idealism. ${ }^{35}$ This was not the first time Kooijmans indicated that an emphasis on morality in foreign policy set the Netherlands apart from other countries. In one interview, when asked whether in international affairs the Dutch sometimes operated as missionaries, Kooijmans replied: 'I am proud of that. We care about human civilisation. We care about the quality of international society. The Netherlands often leads in this ... It is correct that the Netherlands, within the European Union, has made out a case for measures against the Serbs. We also did so under my predecessor Van den Broek. But me too, I feel that one cannot, on this point, adopt a purely pragmatic approach. I just cannot bring myself to conduct Realpolitik in relation to Yugoslavia. One cannot and may not think in terms of: what has the Netherlands got to do with this? Where is our economic interest? ... I also think that the Dutch population and Parliament ask of me that I openly protest against violations of human rights ... I receive more parliamentary questions about human rights violations than most of my foreign colleagues. That says something about the mentality of our country. ${ }^{36}$ Biegman too emphasised the qualitative difference between the Netherlands and other Western states, saying that 'the Netherlands fulfilled a role in New York and in EC policy by occupying the moral highground and consistently pointed out who was the aggressor, who the victim and who committed most war crimes.. ${ }^{37}$

Even though it would depend on other countries to turn the principles defended by the Netherlands into reality, the Dutch felt their criticisms of the VOPP to be entirely justified because a better deal was not just a moral obligation but a practical possibility. According to Biegman, 'there was a feeling that a better deal could be had for the Muslims'. ${ }^{38}$ All it seemed to require was for the newly elected US administration, headed by 
president Bill Clinton, to show the kind of courage so conspicuously absent in places like London, Paris and Bonn. As Kooijmans put it, 'We advocated military intervention as an alternative to the VOPP. The idea was to involve the Americans but that did not succeed. We were saying to the Americans: "Come in with your troops and help us improve the plan: a better map, a better governmental structure, help us reintegrate the country."'39

As Kooijmans's remark indicates, the Dutch policy of persuading the US to use its military power to improve the lot of the Bosnian Muslims ultimately failed. Nevertheless, in January and February 1993 the omens for greater American involvement seemed good. Both during the transition and following Clinton's inauguration as President on 20 January 1993 senior figures in the new Administration aired critical comments about the VOPP. The main message from Washington was that the plan rewarded ethnic cleansing and therefore was morally unacceptable. Thus, the US Ambassador to the United Nations and later Secretary of State, Madeleine Albright, said in a press conference on February 24, 1993 that the plan amounted to 'rewarding aggression and punishing the victims.'

While the US objections against the VOPP fell on receptive ears in the Netherlands, the ensuing public disagreements between the ICFY cochairmen and the Clinton administration caused an acute conflict of loyalty for the Netherlands. So far, the Dutch had not made public their objections to the VOPP in order not to undermine EC unity. According to Kooijmans, it was 'possible to show oneself to be very critical within a closed front.' ${ }^{40}$ But the increasingly open conflict between the ICFY and the US, in which the ICFY co-chairmen called upon the EC member states to maintain a united front towards the US, embarrassed the Netherlands.

Uncomfortable with the ICFY's approach, Kooijmans tried to convince the Europeans that American support for the VOPP was going to be necessary. In a meeting in The Hague on February 4 with the EC Ambassadors to the Netherlands, Kooijmans said that he was worried about 'Lord Owen's criticisms of the US stance', because he 'considered close cooperation with the US of greatest importance' if implementation of the plan was to succeed. Kooijmans also told the Ambassadors that he saw four possible scenarios in relation to the American stance, ranging from outright rejection to unconditional acceptance of the VOPP, neither of 
which he considered likely. There were two alternatives: the US might accept the plan but distance itself from the implementation or might demand changes to the plan which would make US support possible. Kooijmans believed that the latter option was the 'least unfavourable' and concluded his briefing by repeating that the Netherlands thought it of 'essential importance' that the US would be involved as closely as possible in the implementation of the VOPP. Despite having been ambiguous about the question of whether or not the Netherlands supported the VOPP as it stood, experienced diplomats must have observed that the real Dutch position boiled down to a hope that US involvement would lead to a forceful implementation of an upgraded plan.

The Dutch awaited the first concrete American initiative regarding the Bosnian conflict with great anticipation. On February 10, the new US Secretary of State, Warren Christopher, announced that the US would take six steps to help solve the Bosnian conflict. He announced that the US would 'engage actively and directly in the Vance-Owen negotiations' and called for a number of measures to 'deter Serbia from widening the war'. Crucially, however, he had qualified this apparently forceful US engagement by adding that 'the only way' to end the conflict was through 'negotiation' and that 'no settlement [could] be imposed on the parties. ${ }^{31}$

In The Hague, Christopher's speech was seen as a step in the right direction. In an analysis of the speech, DAV officials advised Kooijmans on how to proceed after Christopher's speech. The paper first encouraged Kooijmans to think that the speech did indeed constitute an important positive step. The American refusal to contemplate imposition on the parties, so it was argued, would strengthen the position of the Bosnian government in relation to the ICFY co-chairmen: '[T] he US has picked up the thread where the negotiators had left it... Particularly Owen seemed to believe that pressure on the Muslims would bring results... From the fact that the Muslims are not really prepared to negotiate as long as they are the victim of Serb attacks and ethnic cleansing, the Americans draw a different conclusion than Owen and Vance, namely that the Bosnian Serbs must be forced to make more concessions.'

The DAV memo also expressed the belief that the US was taking the time necessary to achieve a 'more acceptable settlement'. While fundamentally positive about the new US involvement, DAV also warned that the 
American search for a better settlement, however much welcomed by the Netherlands, would require additional time and that in the process a 'vacuum could arise that endanger[s] the peace process'. American involvement, it was added, should 'not lead ... to a deterioration of the situation on the ground'. In order to prevent this from happening, Kooijmans was advised to encourage the Americans to indicate which specific improvements to the plan they had in mind. This could be done at a forthcoming gathering of NATO Ministers on February 26.

In Brussels on February 26, Kooijmans took up a position that was strongly supportive of what he believed to be the American position. Whereas his British and French colleagues made a case for supporting the VOPP as it stood, Kooijmans argued that, since the plan had not yet been accepted by all the belligerent parties, there should exist a willingness to make improvements to the plan. Welcoming Christopher's statement of February 10, Kooijmans went on to request that the American Secretary of State indicate more precisely which changes the US thought the VOPP required. As the meeting wore on, however, it became painfully apparent that the Dutch had misread the American attitude. American difficulties with the VOPP, it turned out, were not so much that the plan was not ambitious enough but that it was overly ambitious and regarded as a European entrapment exercise. The US Secretary of State did not call for changes to the VOPP at all. Instead he simply stated that it was up to the Europeans to take the lead and increase their efforts.

It was now clear that American troops were no more likely to fight for the Bosnian Muslims than were Dutch troops. The Dutch realised that the better deal they had encouraged the Bosnians to hope for might, after all, not be had. Worse, the political vacuum the DAV memorandum had warned against was already coming about for there was no alternative negotiating track available. The feared deterioration of the situation on the ground now also constituted a harsh reality. Particularly in Eastern Bosnia, Serb forces were overrunning the Bosnian Muslims, who had in early January still controlled substantial amounts of territory. Most of the VOPP's province number seven, intended as a Muslim-majority province, threatened to fall into Serb hands. By mid-April the last Muslimcontrolled territory around Srebrenica in Eastern Bosnia was at risk of falling to the Serbs. With Srebrenica gone so would be the last chance of implementing the VOPP. 
Fortunately, it seemed, on May 2 the Bosnian Serb leadership finally signed the VOPP but four days later the Bosnian Serb Parliament refused to endorse their leaders' signatures and announced a referendum, which they knew would lead to a rejection of the plan. For the US, to whom imposition of the plan on the Serbs was anathema, this signalled the death of the VOPP. Britain and France subsequently arrived at the same conclusion given that they were reluctant to implement the plan without American military support. ${ }^{42}$ The Netherlands, which still did not have any combat troops on the ground in Bosnia, went the other way. Seeing that tripartition was now approaching fast, it became a staunch advocate of the plan.

Two weeks before Karadzic signed the VOPP, the Security Council had adopted resolution 819 (April 16), which demanded that Srebrenica and its immediate surroundings be treated as a 'safe area'. Given that Srebrenica's safe area status apparently helped the enclave to stay out of the hands of the surrounding Serbs, Kooijmans felt that an expansion of the safe area concept might be a good way of supporting the VOPP. 'Our linking of the VOPP with the safe areas can be explained by our concern that tripartition was approaching. Even in the VOPP, these areas were for the Muslims. Our plea for safe areas was aimed to ensure that it would not get even worse. ${ }^{43}$ Having advocated safe areas at a General Affairs Council (GAC) in Copenhagen on April 26, the next opportunity for Kooijmans to make the case for safe areas constituted a meeting with Christopher on May 7 at the Dutch embassy in Bonn.

The meeting with Christopher demonstrated how far apart the Netherlands and the US had moved regarding the VOPP. Christopher was touring Europe to rally support for a so-called 'lift and strike' policy. ('Lift and strike' meant a lifting of the arms embargo and the launching of air strikes in order to prevent the Serbs from overrunning the Muslims during the period the latter would need to obtain more weapons once the embargo had been lifted. The Europeans, whose troops would be caught up in the ensuing escalation, refused to support it.) Before he met with Kooijmans, Christopher had signalled in earlier meetings with the British, Danish and Belgian members of the EC Troika and in a meeting with Commissioner Van den Broek that he believed the VOPP was off the table. Ironically, Christopher told Kooijmans that he believed that the US and the Netherlands thought 'along similar lines'. Christopher confided in 
Kooijmans that the US believed the VOPP for the time being should be laid aside but that he had come under the impression in his consultations with the EC-Troika the day before that they were still clinging to the plan. However, according to Christopher, for the near future the plan was not an implementable option. It was not dead but at the most something for later. It must have come as a surprise to Christopher, given earlier Dutch policy, that Kooijmans disagreed. Pointing out the potentially disastrous humanitarian consequences of the US-proposed policy of 'lift and strike', Kooijmans instead suggested the creation of safe areas, arguing that it protected the most vulnerable civilian population and in fact left the VOPP intact, because it concerned areas that in [that plan] belong[ed] to the "muslim provinces"' The two politicians parted after Christopher had expressed serious doubts about the safe area concept (see chapter 5).

While the Netherlands had finally come round to supporting the VOPP, even in the face of continued American opposition, Britain and France moved in an opposite direction. Having consistently supported the VOPP, they now decided they could not save the VOPP if there was not even a basic American willingness to support it. The plan's death sentence was signed by the US, Russia, Britain, France and Spain on May 22 in the so-called Joint Action Programme (JAP). The final negotiations for the JAP had taken place during the previous weekend, outside the UN, ICFY and EC frameworks, and the result constituted an intergovernmental agreement between five governments united by their membership of the Security Council. The JAP no longer spoke of the VOPP, referring to the Vance-Owen 'process' instead. To soften the blow for international opinion, heal transatlantic divisions and divert attention from the real problem, namely their unwillingness to fight the Serbs over the VOPP, the five governments announced a number of ad-hoc measures, such as the creation of additional safe areas and the establishment of a war crimes tribunal.

The Netherlands understood what was going on and protested in vain. According to Kooijmans, 'the JAP was to a certain degree even worse than the VOPP. It was much more of a diktat than the VOPP and it was a breaching of the EC by France and Britain. This caused irritation. ${ }^{34}$ The Dutch government protested: the US Ambassador was summoned to the Ministry and in a sharp-toned telegram to his EC colleagues, Kooijmans stated that there seemed to be a 'discrepancy between the [JAP] of the 5 
[Security Council] members and the earlier positions of the Community and its member states, particularly concerning the Vance-Owen Peace Plan (VOPP).' In conclusion, the telegram summed up the Dutch position:

The Netherlands is of the opinion that the VOPP should remain the overall political framework for a solution of the conflict in Bosnia-Herzegovina and that acceptance of the plan by all the parties to the conflict remains the goal of the international community.

The Dutch criticisms of the JAP were repeated in an uneasy telephone conversation between Kooijmans and his French colleague Alain Juppé. According to Kooijmans, the latter was 'very defensive' when Kooijmans expressed his concern that the JAP might harm the VOPP. When Juppé asked Kooijmans whether it was not the case that the Netherlands had consistently championed safe areas, Kooijmans replied that this was true but that the Dutch 'had advocated safe areas within the context of the VOPP and that they should never be allowed to develop into ghettos'.

When the Netherlands opposed the VOPP in January and February, it had stood isolated. Now that it supported the plan, the country again stood isolated.

To some degree the Netherlands had carried responsibility for the continuation of war, the reduced solidarity between the EC member states and the diminished credibility of the ICFY, developments that were not in a smaller state's interest. Dutch policy encouraged the Bosnian government - with whom the Dutch were in constant touch - to refuse acceptance of the VOPP at a stage where their hold on east Bosnian land was still considerable. The Dutch attitude also awarded a degree of European legitimacy to the American opposition to the plan and helped to undermine the credibility of the ICFY. The Dutch Foreign Ministry may not have recognised this, pinning its hope on an American willingness to 'improve' the VOPP through the use of force. When the Dutch finally discovered that American opposition to the VOPP was not primarily motivated by principled objections, but by a self-interested but valid concern that the plan's implementation would be too costly in terms of American lives, the damage had already been done. While the Dutch belatedly changed course, so did the countries with combat troops already deployed as part 
of UNPROFOR, notably the UK, France and Spain. Although ready in principle to implement the VOPP with American support, these countries' enthusiasm had dwindled as each day of Bosnian/Dutch/American opposition had strengthened the Bosnian Serb army's control over Bosnian territory, making an imposition of the plan ever more costly in terms of their own soldiers' lives.

\section{The Plan for a Union of Three Republics}

The Netherlands had belatedly come to the aid of the VOPP because it was recognised that a worse alternative was in the making. When the contours of this alternative became known, initially the Foreign Ministry refused to support it and for a while continued to cling on to the VOPP as if it was still possible to reach agreement on that basis. In an internal Foreign Ministry memorandum the deputy-director for European Affairs wrote that the new plan, the precise contents of which were as yet unclear but seemed to point towards tripartition, could be seen as the 'fatal blow to the VOPP'. He warned that 'the Twelve should beware of exchanging a non-perfect plan for a bad plan as a result of pressure from circumstances or Lord Owen.' It took several months for the Dutch to accept the new plan as the basis for Western diplomacy.

According to Kooijmans, idealism means that you cannot obtain the agreement of the aggressor by forcing the victim to lie on his back. ${ }^{35}$ Hence, idealism required opposition to the Union of Three Republics because it was believed to do precisely that. Indeed, the plan was not ideal from the Bosnian government's point of view. Initially, the Serbian and Croatian presidents had only offered 23 per cent of Bosnia-Herzegovina's land to the Bosnian Muslims. Never before had the two presidents been so open about their respective sponsorship of the Serbs and Croats in Bosnia. In subsequent negotiations, Owen and Thorvald Stoltenberg, former Norwegian Foreign Minister and successor to Vance as UN special representative and ICFY co-chairman, raised this percentage to 30 per cent, an achievement that was announced on July 9.

Dutch public opinion was not ready for the direction in which the negotiations were now going. Over the past weeks, the government had done nothing to prepare it for what was happening, let alone made an attempt to explain why. As a result, a storm of moral outrage erupted in Amsterdam 
and The Hague. Demands were made for the government to defend the London principles and exert strong pressure on the villain of the piece, Lord Owen, to either step down or to stick with the principles. ${ }^{46}$ This is not to suggest that subsequent Dutch policy was driven by public opinion for Kooijmans and his advisers all personally supported this line as well. It does show that a shared sense of direction for Dutch foreign policy still very much existed.

On July 29, Foreign Minister Kooijmans sent a letter to his Belgian colleague protesting against the Union of Three Republics. The Dutch government was said to be 'concerned that the negotiations in Geneva could lead to a settlement, which would in many respects be at odds with the basic principles subscribed to in London and Copenhagen.' Neither EC representative Lord Owen nor, it seems, most other EC member states received copies since three weeks later the Dutch government felt it necessary to point out in a separate telegram that partners 'should be aware' that this letter had been sent.

During a telegram exchange, it turned out that Germany shared the Dutch position. On August 9 Germany let it be known that it had reservations about the negotiations being conducted in Geneva. The Germans expressed scepticism as to whether the plan for a 'Union of Three Republics' could produce an outcome that was fair and equitable on the basis of the London principles and reconcilable with the principle of territorial integrity and sovereignty. The Dutch government on August 10 backed up Germany, informing EC capitals that the Netherlands found 'itself in full agreement with the German position'. On August 11 the German and Dutch messages were countered by Lord Owen, the Belgian EC Presidency, Britain, Spain and Portugal, all of whom argued that the ICFY was pursuing the best possible settlement under the given circumstances and needed full support.

Encouraged by the German criticisms, Kooijmans stepped up the pressure on the ICFY to come up with a better deal. In a further development of its position on August 19, The Hague pointed out the weaknesses in the plan's constitutional proposals, which did indeed point towards tripartition but had been agreed to by all three of the conflicting parties on July 30. As for the plan's map, which was still under negotiation, the Dutch telegram argued that because of the 'extreme weakness' of the 
Union of Three Republics, a 'much larger territory than proposed by the Serbs and the Croats' was needed for the Bosnian Muslim republic. The Dutch government therefore had 'much sympathy for President Izetbegovic's demands in this respect'. Finally, the telegram warned that there was a chance that the Netherlands would not take part in the plan's implementation with ground troops, given the Dutch doubts that the outcome of the negotiations would 'indeed correspond to the notion of a fair and viable settlement'.

Dutch and German 'dissent' over the Union of Three Republics put a strain on EC unity. In order to address this problem, the ICFY co-chairmen visited the German and Dutch Foreign Ministers on August 25. The meetings showed that it was difficult for both Kinkel and Kooijmans to accept the Union of Three Republics but that the Dutch attitude was more uncompromising. Nevertheless, for the Dutch Foreign Ministry the meeting constituted a sobering confrontation with reality and the beginning of a fundamental break with the policies of the past few months.

Having visited Kinkel in Frankfurt, Owen and Stoltenberg arrived in The Hague to meet Kooijmans. According to Hoekema, the prevailing mood in the Foreign Ministry prior to the meeting was one of barely suppressed hostility. The Dutch were determined that the two co-chairmen 'would be given a proper dressing-down' and to impress upon them that if they wanted the Netherlands to support their proposals, these would first have to 'pass the ethical test'. ${ }^{47}$ In one section of his speech notes for the meeting, Kooijmans' civil servants advised him to express his understanding that the negotiators were no longer in a strong negotiating position vis-àvis the Serbs, since ... 'the world lost its nerve on the Vance Owen Peace Plan' (a reference to the Joint Action Programme). Nevertheless, Kooijmans was also urged to express Dutch concerns about the peace plan. According to the notes, Kooijmans was to say that he was under the impression that "the great emphasis on "realism" and "negotiability" [had] caused the concept settlement now on the table to be determined to a large extent by the military superiority of the Serbs, to the detriment of a number of important principles, as established in London and Copenhagen.'

In another section of his speech notes, Kooijmans was advised to point out towards the end of the meeting that, since Owen and Stoltenberg 
negotiated on the basis of a mandate given by the European Community, the Dutch government would also be accountable for its joint responsibility for the end result of Owen's and Stoltenberg's negotiations. This responsibility existed 'towards those whose future was at stake in the first place' but also towards the Dutch Parliament and public opinion, both of whom were following the Geneva negotiations with 'intense and often critical and concerned attention'.

As a Dutch report of the meeting shows, Kooijmans closely followed his speech notes. During the meeting he asked Owen and Stoltenberg whether there was not a risk that the international community would conclude in a few years time that they had been 'fools' to commit themselves to this agreement and take on the responsibility for its implementation. As both the Dutch and Owen's reports state, the ICFY co-chairmen explicitly admitted that they shared many of the Dutch concerns. Both reports also show that Owen subsequently posed the question of whether, in the absence of a better alternative, one was not forced to take what was on offer. Touching upon this dilemma, the Owen report made an interesting comparison between the attitudes of Kooijmans and Kinkel and revealed a crucial difference between the two. Both Ministers were 'sceptical' about the proposal. They were both 'concerned in general' about the viability and durability of the proposed settlement and 'concerned that the Muslims, as the weaker party, were basically being forced into accepting this solution'. Both Kinkel and Kooijmans 'worried about parliamentary and public reactions' and, finally, 'admitted they could offer no alternative proposal'. In thinking through the consequences of this admission, the two Foreign Ministers, however, had parted company:

Kinkel seemed convinced that for all its perceived faults, the proposal on the table at least offered the best way of getting peace. Kooijmans, however, did not seem to accept that the alternative, continued and intensified war, justified acceptance of the proposal. ${ }^{48}$

According to several officials and by his own admission, Kooijmans had strong opinions about the Yugoslav crisis. The 'Kooijmans factor' is said to have been all-important. His idealism gradually began to 'provoke bureaucratic resistance. ${ }^{49}$ Kooijmans, while admitting that he did have strong views about the Bosnian war, later argued that there were other 
Cabinet members with even stronger views: 'Don't forget that within the Cabinet I was still a dove. ${ }^{50}$ Kooijmans' remark raises the question of whether the Yugoslav crisis featured a lot in Cabinet meetings. Both Relus Ter Beek and Voorhoeve lamented that during their respective terms as Defence Minister - which include the years 1990-1995 - Dutch policy regarding the Yugoslav crisis was not the subject of an in-depth discussion in the Cabinet even once and that, instead, the Foreign Minister possessed a large degree of autonomy. ${ }^{51}$ It would seem, therefore, that Kooijmans' primarily meant his immediate colleague the Minister for Development Cooperation, who articulated strong views at times.

The meeting with the ICFY co-chairmen seems to have brought home for the first time the uncomfortable truth that a failure of the plan was unlikely to lead to a better deal for the Bosnian Muslims. A memorandum signed by Frank Majoor, Van Eenennaam's successor as director of DAV, laid out the options one by one. Its careful phrasing suggests that it was felt that the implications of the message would take time to sink in with Kooijmans. According to the DAV memorandum, if the Bosnian government rejected the plan it would end up being greatly disappointed. The Bosnian government would probably reject it in the expectation of three alternative measures being taken in isolation or together: air strikes, a strengthening of the international military presence on the ground and a lifting of the arms embargo. DAV feared, however, that none of the three measures would be implemented and that in the absence of a settlement there was a great risk that 'the situation for the Muslims [would] quickly deteriorate.' In what was essentially a call for Kooijmans to add water to the principled Dutch wine, the paper argued that none of the options open to the Netherlands in the case of a Bosnian Muslim rejection of the plan (ranging from a call for nominating new negotiators to a plea to lift the arms embargo) could prevent the outcome that the amount of Muslim-held territory would 'probably be less than what [was] now on offer.'

While it would have been impossible for Kooijmans to openly admit it, given the fierce public criticisms in the Dutch media of Owen, the Foreign Ministry changed tack. The London principles were abandoned as the fundamental yardstick by which to measure whether a peace plan deserved Dutch support. Instead, the Netherlands began to focus on the need for a 'fair and viable settlement', a definition internationally accepted and broad enough to allow negotiations to go in various directions. 
According to Kooijmans, the change in Dutch policy was motivated by 'the acceptance of the inevitability of tripartition. You must learn to live with it. You must not close your eyes.'52 In addition to the meeting with Owen and Stoltenberg, what had possibly helped change the minds of Kooijmans and his officials was a remarkable publication in the June edition of the Internationale Spectator, the Clingendael Institute's international relations monthly. It had been written by three of the institute's most senior experts, including Joris Voorhoeve, who was to become the Minister of Defence less than a year later. They had offered six options for peace in Bosnia, two of which came with rough maps that so obviously conflicted with the London principles and required such additional amounts of (voluntary) ethnic cleansing that no international negotiator could have proposed them without inviting immediate calls for his resignation. The article concluded in favour of a combination of safe havens and complete tripartition: 'New negotiations must be opened with all three of the parties in order to realise a tripartition of Bosnia-Herzegovina, which will finally stop the war and create a Bosnian buffer state between Serbia and Croatia. ${ }^{53}$

No longer challenging the principle of tripartition, the Dutch government focused on how to obtain an additional 4 per cent of territory for the Bosnian Muslims. In doing so, the Netherlands, together with Germany and the US, backed a demand to that effect by Bosnian President Izetbegovic. Eventually, at the end of September, the Bosnian (Muslim) assembly in Sarajevo rejected the Union of Three Republics. While the cycle of escalating demands had not been broken yet, the Netherlands was now working within, rather than against, the established political framework for peace. With the changed German and Dutch positions came an opportunity for the EC to throw its collective weight behind the ICFY and its plan. Interventions by Dutch officials within the framework of EPC revealed the degree to which the Netherlands had changed course. On September 6, in a meeting of the committee on Yugoslavia (Coyug), a Dutch official said that 'given the very weak position of the Union in the constitutional set-up, the division of the territory between the three republics [was] all the more important in the search for a "fair and viable" settlement.' The official subsequently backed up Bosnian government's demand for nearly 4 per cent of additional territory, which included access to the sea and a wider corridor to the East Bosnian enclaves than envisaged in the plan. In the CoPo meeting of September 7 
and 8, the new Director-General for Political Affairs, Joris Vos, took up the same position. Vos repeated the call for access to the sea and corridors to the enclaves so that the Bosnian Muslim territory would indeed be 'viable'. In both meetings Germany had taken up a similar position and it seemed the internal European division was beginning to disappear, given that the discussion of the political directors 'lacked the sharp and bitter tone that [had] so marked the exchanges of thoughts on this point during the past year'.

To summarise, between June and September 1993, the Dutch Foreign Ministry went through the same motions over the so-called Union of Three Republics as it had over the VOPP. The primary reaction was one of outright hostility and moral indignation. Subsequently, when the Foreign Ministry was forced to admit that a better deal could not be had, the Union of Three Republics was supported as the only plan available. Measured in terms of Dutch interests, the damage had been substantial. The Netherlands had alienated itself from important European partners, the credibility of the ICFY regime had been further undermined, and the Bosnian government had been encouraged to continue a war that had been characterised for months by military stalemate.

During October, following the refusal of the Bosnian government to accept the Union of Three Republics plan as it stood, the EC nevertheless continued to support the plan, believing it possible to obtain all-party agreement if more territory could be found for the Bosnian government. Eventually, the hitherto solely German-Dutch position of support for additional territory became the EC's formal approach after Germany had found France prepared to present it as a German-French initiative. The plan, which essentially remained the same but formalised the need to give the Bosnian Muslims one-third of Bosnia's territory, became known as the EU Action Plan.

\section{The EU Action Plan}

The Netherlands was very happy with the content of a letter from German and French Foreign Ministers Kinkel and Juppé to the Belgian EC Presidency on November 7, 1993. One of the key points in the letter was a demand that the Muslim-majority republic would get an extra 3 per cent of territory, bringing its total percentage up to one-third of 
Bosnia-Herzegovina. Following a further elaboration of the FrenchGerman letter by the Belgian Presidency, the initiative came to be known as the EU Action Plan.

Dutch policy towards the EU Action Plan was one of loyal support. That the Netherlands should be so supportive cannot simply be attributed to the moral quality of the peace plan. For that, the plan resembled the Union of Three Republics too closely and, while it would be easier to implement than the VOPP, in moral terms it constituted the tripartition the Dutch had so long regarded as the outcome to be avoided. The Foreign Ministry's support for the EU Action plan was in part motivated by the same consideration that had led it to support the Union of Three Republics from September onwards. This was recognition of the fact that opposition to a bad plan did not necessarily translate into an ability to offer something better.

Dutch support for the EU Action Plan constituted more than a grudging acceptance of the inevitable. There was a remarkable enthusiasm about the plan and an eagerness for the Bosnian government to accept it and thereby end the war. Two additional reasons help to explain this newfound Dutch emphasis on the need for a rapid settlement. First of all, there was a belated recognition of the threat of international isolation. The fact that Germany co-sponsored the EU Action Plan required the Netherlands to support it or else risk complete isolation within what was now officially the European Union. In Kooijmans' words, 'you must, of course, avoid becoming isolated. ${ }^{54}$ Moreover, given that the plan took account of the American-backed demand by the Bosnian government for one-third of the country, it seemed that the US would support the plan as well. As Kooijmans put it, the EU Action Plan seemed to possess 'a greater viability [than its predecessors] because of possible US involvement. ${ }^{55} \mathrm{On}$ the basis of this assessment of American attitudes, for the Dutch to oppose the EU Action Plan would have lifted the Netherlands out of what seemed an Atlantic - not just European - consensus.

While a minority of senior officials in the Foreign Ministry continued to argue as late as mid-November that the EU Action Plan was morally unacceptable and did not deserve Dutch support, Kooijmans, the Director-General for Political Affairs and the director of DAV agreed that the plan should have full Dutch backing. At a GAC on November 22, 
Kooijmans told his colleagues that it was with a heavy heart that he had to accept that the London principles could no longer guide international diplomacy. He acknowledged that they had 'disappeared from sight' and that it would make the plan 'schizophrenic' if they were to be included in the package. Moreover, he said that 'in view of the looming humanitarian disaster, a peace settlement ... was now necessary'. Kooijmans even accepted that the suspension of international sanctions against Serbia and Montenegro was a price that had to be paid if peace could thereby be obtained.

Having come out in support of the plan, Kooijmans immediately went an important step further in focusing all of the Dutch energy on obtaining concrete American support. In contacts between Joris Vos and an American official, Vos pointed out that without a settlement a humanitarian disaster might take place during the coming winter. This meant that, despite the plan's weaknesses, an effort should be made to reach a settlement on this basis before the winter. Vos formally requested the US Administration's 'political support' and 'cooperation' in the Security Council for the 'phased suspension of the sanctions', as well as US 'participation' in the implementation of the plan.

Despite an unequivocally negative response from the USA to the Dutch overture, the Netherlands continued to try and engage Washington. However, the USA let it be known that it did not want to exert any pressure on the Bosnian government, opposed suspending sanctions and would probably not take part in an implementation force. Another occasion to try and influence American thinking occurred with a meeting between Dutch Defence Minister Relus ter Beek and his US colleague Les Aspin. They met on December 9 in the margins of a NATO Defence Planning Council, which brought together all NATO member states' defence Ministers. The key issue discussed by Ter Beek and Aspin was the Bosnian government's request for explicit NATO security guarantees if it were to sign up to the EU Action Plan. What was in effect meant by NATO security guarantees was US guarantees. So when Ter Beek met Aspin he said that the Dutch government saw the safe area operation as 'a temporary matter' and hoped that there would soon be a general settlement. 'I said that, surely, the Americans could not be absent during its implementation, whereby I mentioned Haiti, meaning our willingness to contribute troops there. I proposed that US troops would make up half 
of the implementation force. ${ }^{36}$ However, despite Ter Beek's plea for a military involvement on the part of the US, Aspin's reply was non-committal. The American response was that the Bosnian demand for NATO guarantees caused concern in Washington and that it would be difficult to explain that such guarantees would be given to 'the absurd rump-state of Bosnia but not to Poland.'57 An additional American objection was raised the next day in NATO, making it all too clear that the US did not intend to support the EU Action Plan. A Dutch official had argued for NATO contingency planning so as to enable the Bosnian government to make peace but this was followed by a cold American rebuke. The Bosnian government and the ICFY were too quick in assuming, so ran the American argument, that NATO should be the organisation to give guarantees. Since the negotiations took place under the aegis of the UN, the Security Council was the more appropriate body to extend such guarantees.

Such was the eagerness in the Foreign Ministry to see the EU Action Plan succeed that some voices dared question the continued existence of the safe areas. This sudden scepticism regarding the safe areas, aired in particular by the European Affairs Department, was motivated in part by a growing feeling that the safe areas were an obstacle to peace, as well as by hints from the Bosnian government that it was willing to discuss a territorial trade-off.

Kooijmans later commented that his moral indignation did not prevent him from understanding the dilemma that lay before him and his Western colleagues: 'the longer safe areas continue to exist, the more they become an anomaly; you have to embed them in a plan. ${ }^{58}$ Surprisingly, it was the Netherlands of all EU member states that raised the issue in the context of European Political Cooperation. The new-found Dutch pragmatism was motivated in part by a message received from the Bosnian government. In a conversation with Bosnian Prime Minister Haris Silajdzic on November 30, 1993 Kooijmans was told that the Netherlands was the Bosnian government's 'friend' and 'most important ally' in the EU. Silajdzic added that, despite the Bosnian government's critical public stance, 'the Netherlands should know that the Bosnian government was prepared to fall back on a settlement that awarded them one-third of the territory.' The Dutch Foreign Minister understood the significance of these remarks and asked Silajdzic whether the Bosnian government 
'would be prepared to exchange the enclaves in Eastern Bosnia for territory around Sarajevo', something 'Lord Owen [had] mentioned as a possibility'. To this, Silajdzic replied that it was 'very difficult', but that the Bosnian government did 'not totally say no to that'.

Silajdzic's reply and the subsequent problems for the Netherlands in doing something useful with this interesting message showed the degree to which the safe area policy had become counter-productive. For even if there was silent agreement among the Bosnian government and its Western supporters that ultimately the eastern enclaves would have to be given up as part of a territorial settlement, who would be the first to say so publicly? The answer was 'nobody' for no Western politician would have dared to begin explaining such a moral defeat to his or her domestic audience. This was also true for Dutch politicians whose rhetoric had been among the most explicit. Clearly, the Security Council's half-hearted but very public commitment to the Bosnian safe areas foreclosed the option of a withdrawal, while the option of defending the safe areas was seen as too potentially costly to be credible. To complicate matters, moreover, Silajdzic had mentioned that the Serbs were not prepared to give something in return for the enclaves, while the Bosnian government refused to contemplate the population exchange envisaged by the Serbs. In sum, the message from the Bosnian government was the kind of information that was crucial and useless at the same time. It was crucial because it was the clearest possible indication of the outcome one could see looming on the horizon. It was useless because this outcome was so clearly unacceptable to Western audiences that no credible political follow-up existed.

Nevertheless, the Foreign Ministry with its interest -although not articulated - in reaching a settlement before the troop commitment to the safe areas was to materialise, raised the issue of a territorial exchange in the context of the EU's Common Foreign and Security Policy. If the EU could be mobilised against the odds to support the idea of a territorial exchange, then perhaps a settlement could be reached fairly quickly. Hence, in the Committee of Political Directors in the margins of a General Affairs Council on December 6, 1993 the Netherlands expressed its 'concern' about the wish of the Bosnian government to 'draw in' the EastBosnian enclaves into its future republic. The creation of such a territorial 'link-up' of 'Muslim-territories' would result in a 'Serb enclave', which 
would in turn 'guarantee an unworkable situation'. The explicit and uncharacteristic Dutch intervention seems not to have triggered a meaningful response. Rather, on December 11 the EU once more declared that it regarded as legitimate the Bosnian government's demands for onethird of the country and access to the sea, a message Kooijmans repeated during a visit to Sarajevo on Tuesday December 14, 1993.

By the end of December 1993, American officials were openly saying that the EU Action plan had reached a dead end. Despite this depressingly negative stance on the part of the US, the Netherlands refused to give up. On December 29, Foreign Ministers Kooijmans and Kinkel sent a letter to Bosnian President Izetbegovic, the tone of which showed that Dutch patience with the Bosnian government was wearing thin. Kooijmans and Kinkel informed Izetbegovic that 'reports of a Muslim offensive against Croat settlements in central Bosnia' were causing them 'great concern'. The two Foreign Ministers continued:

The European Union has called on the Serb side to stop the shelling of Sarajevo and other Bosnian cities. We are urging the Croats to show moderation. But we would also wish to appeal urgently to your side in the interests of your long-suffering people to avoid any action that could extinguish the present chances of peace. Peace can only be achieved at the negotiating table.

For the Netherlands to exert this kind of pressure on the Bosnian government was unprecedented and showed the degree to which the Netherlands wanted the EU Action Plan to succeed, but it was to no avail. Following another round of failed talks, there was widespread agreement by the end of January 1994 that the EU Action Plan was indeed dead.

Kooijmans still refused to give up and he implored his European and American colleagues not do so either. In a long letter to his European colleagues, dated January 26, 1994, Kooijmans called on them to continue the humanitarian mission in Bosnia. As for the peace negotiations, he suggested that the EU should try to 'promote actively a better relationship between Croats and Muslims' and 'to try to involve the US and the Russian Federation as much as possible in efforts to bring the peace negotiations forward'.58 The letter to his European colleagues was followed by a 
letter to US Secretary of State Christopher: 'My feeling is that we have reached a crucial stage in the process and that, if we join our efforts, it might be possible to obtain a settlement which would meet the justified Muslim demands. Now that the French as well seem to be moving in that direction, I would strongly urge the US to associate itself more closely with the political process and become more actively involved in devising and promoting a settlement which [could] be accepted by the Muslims.'

The letters reflected an understandable discomfort with the idea that the plan would fail and Dutch troops would become part of the anomaly which in Kooijmans' words the safe areas had now become. Also, the plan's imminent failure seemed to testify to the weakened ability to manage crises of some of the collective mechanisms the Dutch had placed their faith in, in particular the EU. For the first time since August 1992 the Netherlands had rediscovered its interest in promoting European cohesion. However, from the more powerful member states' perspective, these collective institutions had already failed to deliver and it was time for a new concept that would bind them together without the lumber of smaller players with strong opinions and little of substance to offer. This new concept was the Contact Group, founded in April 1994.

The Contact Group consisted of the US, Russia, France, Britain and Germany, as well as the European Commission and the EU Presidency. Italy joined at a later stage. From April 1994 until the end of 1995 the Contact Group dominated the international community's Yugoslavia diplomacy. With the establishment of the Contact Group, the ability of a middleranking EU member state to influence the international diplomatic and humanitarian/military intervention in the former Yugoslavia was reduced. At the same time, the Contact Group's ability to deliver a diplomatic result was hampered considerably by the stalemate on the ground in Bosnia. In particular the presence of safe areas with lightly armed UN troops in them, hampered the peacemaking ability of the Contact Group. Irony had it that Dutch troops were deployed in the most sensitive safe area of all in February 1994, a safe area that was impossible to defend from a military point of view but impossible to abandon politically. 


\section{Conclusion}

The position of the Netherlands during the period 1992-1995 was fundamentally different from the one occupied in 1990 and 1991 due to external and domestic factors. On the external level, the most important development was the gradual loss of influence by the European Community, renamed European Union in 1993. Lacking a military capability of its own, the EU lost influence as a collective actor in relation to other national and collective actors, notably the US, France, Britain, the Russian Federation and the UN. The Europeans had given a demonstration of their collective political power in 1991 over the recognition issue, which had presented the US with a fait-accompli that was impossible to ignore. But having played the card of recognition, Europe possessed few other means with which to exert a credible influence on the Yugoslav crisis. The US, alarmed by the sudden assertiveness of a reunited Germany, began to play a growing role in determining the political agenda of international intervention, despite remaining on the sidelines militarily.

As a regime, the EU also grew weaker internally. Germany's tactics regarding the recognition issue in 1991 had been widely interpreted as a violation, albeit in spirit rather than formally, of the established norms and principles guiding European foreign policy. With the German precedent set, the other EU member states, including the Netherlands, no longer regarded the cohesion of the EU as a fundamentally important foreign policy interest in itself.

While the ICFY temporarily functioned as the new forum for collective Yugoslavia diplomacy, it exercised fewer and looser constraints on each of the participating states than had the EC. As a norm-setter the 1992 London Conference had been successful, but the collective political will to enforce these norms upon parties in the Bosnian conflict was absent. Gradually, the ICFY began to be replaced by intergovernmental, ad hoc coalitions, which more accurately reflected the limited political will and military means with which the leading states in the international community approached the Yugoslav crisis. Early evidence of this transformation was provided by the intergovernmental preparation and announcement of the Joint Action Programme which, in the words of one senior Dutch official was 'very annoying', because 'we were not part of it. ${ }^{\prime} 0$ The subsequent creation of the Contact Group confirmed the trend. 
On the domestic level, a number of changes occurred too. First of all, the interest in European cohesion, an 'objective' national interest that had functioned as a corset on Dutch Yugoslavia policy in 1991, no longer played an important role. Instead, the Netherlands began to be driven by something that is best described as moral indignation. The impact of principled beliefs on Dutch policy limited the number of acceptable policy options to those that were rooted in the intention to support the 'good' side in the conflict, the Bosnian (Muslim) government, against the 'bad' side, the Bosnian Serbs - with the Bosnian Croats somehow escaping the Dutch attention, given that most people were uncertain in which camp to put them.

Clearly, the Netherlands did exert influence on international Yugoslavia policy during the years under discussion, despite the changes in the international environment and despite the fact that Dutch policy was driven by moral indignation. During the 1992 London Conference, the Netherlands played an important role in the formulation of the principles a Bosnian settlement would have to honour. In the first months of 1993, the Netherlands was the only EC member state not to support the VOPP, arguing that the plan did not honour these principles and that the main victims of the war, the Bosnian Muslims, were entitled to a better deal. Applying a combination of 'moral guidance,' 'demonstration politics', 'public criticism' and a 'small-state alliance' with the Bosnian government, the Netherlands effectively broke ranks with the other EU member states, in the process legitimising Bosnian and American opposition to the plan. Bosnian-DutchAmerican opposition proved the death knell for the VOPP. During the summer months the Netherlands, together with Germany, successfully helped to block the plan for a Union of Three Republics, encouraging the Bosnian government to make additional territorial demands. When the French government too accepted the need for an additional three percent of territory, the Dutch government could claim to have been one of the coarchitects of the third plan, the EU Action Plan, which awarded the Bosnian government an exact one-third of Bosnian territory. Finally, the Netherlands had been an advocate of a formalised UN safe area policy, which was indeed created in May and June 1993.

Unfortunately, influence does not necessarily translate into the achievement of desired policy goals. Having felt morally obliged to oppose the VOPP, the Dutch to their dismay saw the VOPP being replaced by a plan 
that seemed to honour the London principles even less. The Netherlands initially blocked it for the same moral reasons. However, towards the autumn of 1993 the Foreign Ministry changed tack and became more supportive of the international diplomatic efforts, going as far as to propose a territorial exchange involving the East Bosnian enclaves, including Srebrenica. There were two reasons for this about-turn, the first being the recognition of the collective refusal to upgrade the peacekeeping operation into a real military intervention aimed at the imposition of a settlement. Secondly, the Foreign Ministry became concerned lest the absence of an agreed settlement would make the UN's safe area policy - which the Netherlands had so staunchly advocated and to which Dutch troops had already been committed - an 'anomaly', as Foreign Minister Kooijmans put it. By the time the Foreign Ministry recognised the approaching entrapment for what it was, however, there was no indication that the collective implementation of a settlement would indeed make the safe area operation redundant.

\section{NOTES}

1 Honig and Both, Srebrenica, p. 73.

2 It also meant that the Netherlands became an important bilateral aid donor to the Bosnian government, financing for instance the water supply system for Sarajevo, which had been damaged by Serb forces.

3 Public Hearings Tijdelijke Commissie Besluitvorming Uitzendingen (hereafter: $T C B U)$, The Hague, 22 May.

4 'Final Report of the United Nations Commission of Experts Established Pursuant to Security Council Resolution 780 (1992)', para. 175. See on the Serbian strategy of ethnic cleansing: Honig and Both, Srebrenica, pp. 71-77.

5 Trouw, August 22,1992.

6 Jerôme L. Heldring, 'De Breznjev-doctrine van Jan Pronk' (Jan Pronk's Breznjev-doctrine), NRC-Handelsblad, August 25,1992.

7 NOS Laat (NOS Late), August 7,1992.

8 J.J.C. Voorhoeve and M. van den Doel, 'Nederland moet het initiatief nemen tot actie in Bosnië' (The Netherlands should take initiative to act in Bosnia), de Volkskrant, 5 August 1992. Voorhoeve also advocated these ideas internationally: Joris Voorhoeve and Theo van den Doel, 'If the world stands by once again, evil surely will prevail', International Herald Tribune, August 11, 1992. 
9 See: Arie M. Oostlander (Christian-Democrat MEP), 'Europa moet in Bosnië geweten laten spreken' (Europe must let conscience speak in Bosnia), de Volkskrant, August 11, 1992; Arie M. Oostlander, 'Scenario van de jaren dertig. Europa mag niet meewerken aan racisme in Bosnië-Hercegowina' (Scenario of the thirties. Europe may not cooperate in racism in Bosnia-Herzegovina), Trouw, August 7, 1992; Laurent Heere, 'Tijd van praten is voorbij. Oud-Generaal Huyser acht ingrijpen Bosnië onvermijdelijk' (Time for talk is over. Former General Huyser judges intervention Bosnia inevitable), Gooi en Eemlander, August 6, 1992; André Roelofs, 'Kunnen we nog blijven zuchten en protesteren?' (Can we continue any longer to sigh and protest?), de Volkskrant, August 5, 1992; Max Arian and Joke van Kampen, 'Te wapen. Het hoe, wie, waarom en wanneer van operatie Joego Storm' (To arms, the how, who, why and when of operation Yugo Storm), Groene Amsterdammer, August 5, 1992; Bart Tromp, 'Ingrijpen' (Intervene), Het Parool, August 12, 1992; Hylke Tromp, 'Conflict Joegoslavië vraagt om herhaling van Desert Storm' (Conflict Yugoslavia demands repeat of Desert Storm), de Volkskrant, July 3, 1992; 'Nederlandse keuze' (Dutch choice), de Volkskrant, August 13, 1992; 'Geen weg terug' (No way back), Trouw, August 14, 1992; J.J.C. Voorhoeve en M. van den Doel, 'Argumenten tegen ingrijpen in Bosnië zijn niet sterk', (Arguments against intervention are not strong), NRC Handelsblad, August 10, 1992; Alexander Münninghoff and Martijn Delaere, "De Serven gedragen zich als de nazi's" (The Serbs behave like the nazi's), Haagsche Courant/Het Binnenhof, August 8, 1992. Opinion polls indicated that between August and December 1992 some 63 to 68 percent supported Dutch participation in a military intervention and accepted that it would involve Dutch casualties. Source: Jan van der Meulen, 'Hoge verwachting van nieuwe krijgsmacht' (High expectations for new armed forces), Maatschappij \& Krijgsmacht, Vol. 15, No. 1 (February 1993), p. 2; de Volkskrant, August 10, 1992.

10 Owen, Balkan Odyssey, p. 18.

11 Interview Hoekema.

12 Silber and Little, p. 260; Gow, p. 226.

13 Interview Van den Broek. In the official record of the Conference Van den Broek spoke of 'military actions' rather than 'military intervention', but the implication was the same.

14 Silber and Little, p. 260.

15 The texts of the various declarations and decisions have been reproduced in a variety of official publications and political journals. For example: Review of International Affairs Documentation No 1007-8, 1. VIII-1.IX 1992, pp. 15-18. 
16 The others were: the imperative to respect ceasefires; the need to engage in negotiation on the basis of the principles outlined, commitment to seek and accept a final settlement on all questions of succession to the Former Yugoslavia; the obligation to comply with UN Security Council Resolutions; the need to cooperate in the delivery of humanitarian aid; the obligation to cooperate wholeheartedly in international monitoring, peacekeeping and arms control operations; the need for international guarantee to ensure full implementation of agreements reached within the framework of the International Conference.

17 Interview Van den Broek.

18 Gow, p. 110.

19 Interview Van den Broek

20 Report of the Secretary-General pursuant to General Assembly Resolution 53/35 (1998) 'Srebrenica Report', paragraph 102.

21 The term 'pressure group' as a metaphor for the Dutch government was coined by: H.A. Daalder, 'Nederland en de wereld, 1940-1945' (The Netherlands and the world, 1940-1945), in: Van Sas, ed., Kracht, p. 141.

22 See 'Report of the Secretary General on the International Conference on the Former Yugoslavia' UN Doc. S/24795, November 11, 1992.

23 Owen, Balkan Odyssey, p. 91.

24 Peter Michielsen and Robert van de Roer, "Een onderhandelaar moet zijn gevoelens opkroppen"; Lord Owen blikt terug op rol in ex-Joegoslavië' ('A negotiator must crop up his feelings"; Lord Owen looks back on his role in exYugoslavia), NRC-Handelsblad, June 10, 1995.

25 'Nederland in sleutelrol' (The Netherlands in a key role), NRC-Handelsblad, June 12, 1995.

26 'Van den Broek: niet eens met kritiek Lord Owen' (Van den Broek: disagrees with criticism Lord Owen), NRC-Handelsblad, June 12, 1995.

27 Interview Judge Pieter H. Kooijmans, The Hague, May 23, 1997.

28 Interview Hoekema.

29 Interview Ambassador Niek Biegman, August 23, 1995.

30 Wijnaendts, Kroniek, p. 198.

31 Interview Kooijmans.

32 Ibid.

33 Interview Biegman.

34 On the Dutch self-image, see: Scheffer, Een tevreden natie.

35 Interview Kooijmans.

36 Leonard Ornstein and Max van Weezel, 'Wereldse Zaken. Minister Kooijmans is best trots op "hummeltje Nederland"' (Worldly Affairs. Minister Kooijmans is quite proud of "little toddler Netherlands"'), Vrij Nederland, April 16, 1994. 
37 Interview Biegman.

38 Ibid.

39 Interview Kooijmans

40 Ibid.

41 Secretary of State Christopher, Department of State Briefing on the Former Yugoslavia, February 10, 1993.

42 Honig and Both, Srebrenica, pp. 112-113.

43 Interview Kooijmans.

44 Ibid.

45 Ibid.

46 Cf. André Roelofs, 'Bosnia-Herzegovina. De dokter en de psychiater' (BosniaHerzegovina. The Doctor and the Psychiatrist), de Volkskrant, August 12, 1993; M. van den Doel, 'Een schijnoplossing. Plan Owen-Stoltenberg maakt geen eind aan oorlog' (A fake-solution. Plan Owen-Stoltenberg puts no end to war), Trouw, August 5, 1993; Steven de Vogel, 'A visionary. If Germany and the Netherlands abandon their trust in Owen, there will be a crack in the EC', Vrij Nederland, August 28, 1993 ; Christian Chartrier, 'Un commissaire européen dénonce la "stratégie de la capitulation" menée par le négociateur de la CEE', Le Monde, August 31, 1993; Arie M. Oostlander, 'Owen plays the game of the unscrupulous England', Trouw, September 1, 1991.

47 Interview Hoekema.

48 'Bosnia: Co-Chairmen's Meetings with Dutch Foreign Minister Kooijmans and German Foreign Minister Kinkel, 26 [sec] August on Union of Three Republics', David Owen Balkan Odyssey CD ROM.

49 Interviews Hazewinkel, Hoekema.

50 Interview Kooijmans.

51 Interviews Ter Beek, Voorhoeve.

52 Interview Kooijmans.

53 Theo van den Doel, Dick Leurdijk en Joris Voorhoeve, 'Is er een duurzame oplossing voor de oorlog in Bosnië?' (Is there a lasting solution for the war in Bosnia?), Internationale Spectator 47-6, June 1993, p. 313.

54 Interview Kooijmans.

55 Ibid.

56 Interview Ter Beek.

57 Ibid.

58 Interview Kooijmans.

59 Ibid.

60 Interview Hoekema. 



\section{Military Entrapment}

\section{The Commitment to Srebrenica}

On July 11, 1995, the safe area of Srebrenica was taken by (Bosnian) Serb forces. In the immediate aftermath the Serbs killed over seventhousand Muslim men. The great majority of these men were not killed in battle but murdered after having been taken prisoner. ${ }^{1}$ It had taken the Serbs a week to conquer and ethnically cleanse the safe area and it had proved to be a relatively easy task. There had been little resistance from the fourthousand Muslim soldiers in the enclave, the fourhundred Dutch peacekeepers deployed there, or from UNPROFOR as a whole.

Dutch military entrapment in the Bosnian conflict began on June 22, 1993, became concrete in February 1994 and was completed in February 1995. On June 22, 1993, the Dutch government committed itself internationally to an additional military contribution for the specific purpose of implementing the UN Security Council's safe area policy. In February 1994, the first Dutch troop contingent entered the Srebrenica enclave as hostages to their environment. One year later, the Bosnian Serb army stopped all but the most essential goods from entering the enclave of Srebrenica, thereby fully shutting the trap. As became painfully evident, the trap could not be reopened from within nor from outside.

In retrospect it would, perhaps, have been better for everyone had the Dutch government refused to go to Srebrenica - at least at this stage. This much was suggested by the very UNPROFOR commander who eventually assigned the Srebrenica mission to the Dutch troops, Belgian Lt. General Francis Briquemont. 'In November 1993 all countries refused to deploy 
troops in Srebrenica ... I then informed both supreme Commander Cot and the UN authorities that I thought about giving up Srebrenica. The answer from New York came quickly: "Impossible. Do something, general." At that point, after all, the Dutch accepted the mission. But given that by late 1993 I was facing increasingly difficult negotiations with the Serb commander Mladic, perhaps I should have stuck to my original position... If the Dutch government had taken on the same attitude as many other states, a deep crisis would have erupted between the military command of UNPROFOR and the UN leadership. Such a crisis might have been salutary.'2

While one cannot be certain, saying 'no' at this point in time might have had the sobering effect of forcing the Security Council to choose between a credible implementation and an early admittance of failure. Instead, the Dutch government's readiness to deploy troops in Srebrenica helped to legitimise and prolong the Security Council's 'strategy of non-decision' regarding the safe areas. As history would show, the Dutch military entrapment symbolised and exacerbated the international community's entrapment in the Bosnian war that resulted from the UN Security Council's half-hearted safe area resolutions. Gow describes the international safe area predicament as follows: 'What was in any case certain was that without secure logistics lines and a large UN presence the isolated enclaves in eastern Bosnia would be indefensible. They would therefore be no more than symbolically "safe" at the same time as they were hostages to fortune. This placed the UN on a hook for a variety of reasons. First, the Security Council had made a commitment to protecting these areas; second, UNPROFOR was genuinely unable to deter attacks purely by a presence in the "safe areas"; third, deterrence relied on the threat of using close air support to defend the troops, or possibly air strikes, in response to bombardment of the areas; and fourthly, the threat of using air power was neutralised by the vulnerability of the troops on the ground in those areas, deployed in small pockets and cut off from the main force.' 3

Why did the Netherlands consciously and willingly entrap itself in one of these isolated pockets? In order to be able to answer this important question, one really needs to divide it into two separate questions. The first would be why the Netherlands committed additional troops to a safe area policy that was conceptually flawed and not accompanied by firm troop 
offers from those who had sponsored the policy. Secondly, why did the Netherlands decide to take on the Srebrenica mission, by itself, when other countries so conspicuously avoided that destination?

The most important step towards military entrapment, the lone Dutch military commitment to the UN Security Council's safe area policy, was the result of the same factors that had caused the Dutch moral and political entrapment. Externally, there was a steady decrease in international solidarity and a correspondingly weaker international position for the Netherlands. The JAP of May 22, 1993 had been the first indication of the great powers' impatience with the existing multilateral frameworks. ${ }^{4}$ The creation of the Contact Group in April 1994 by Britain, France, Germany, Russia and the US further reduced the strategic-political role of an EU member state like the Netherlands.

In terms of actual Dutch foreign policy, support for the safe areas was an integral component of the trusted approach of anti-Serbian - and proBosnian - selectiveness. The Dutch felt morally obliged to support the safe areas with a troop contribution, just as they had felt morally obliged to oppose the VOPP and the Union of Three Republics. Once the commitment had been made in front of international leaders, such was the political entrapment that even if the conclusion was reached privately by some policy makers that it was better not to deploy troops in Srebrenica, there seemed no longer to be a way back without an unacceptable loss of face.

The second question is more complicated and requires scrutiny of the role played by the Ministry of Defence. While the Ministry of Foreign Affairs remained the lead actor regarding the general Dutch policy of support for the safe areas, the Ministry of Defence's hostility against infantry deployments gave way to a gradual acceptance of, even support for, the assignment. As early as August 1992, the country's most senior officer had spoken out publicly against the safe area concept. ${ }^{5}$ But in August 1993, following constant pressure from Parliament, the press and the Foreign Ministry, the Ministry of Defence switched tack. It was recognised that the domestic-political process and the subsequent international commitments made by the government had created a reality of its own, which the senior officers had to respect even if their military judgment told them not to. 
The Srebrenica mission as it was finally implemented not only differed from, but was more ambitious than what most policy-makers had intended the Dutch military role to be. If we look at the domestic decision-making process leading up to the actual deployment, a process of 'coalition logrolling' seems to have taken place, with the Ministry of Defence supporting deployment of the airmobile battalion in Srebrenica in return for its key bureaucratic-political interests being served.

We will first describe briefly what the military entrapment of February 1994 - July 1995 looked like from the perspective of the policy makers and decision makers back in The Hague. Subsequently, we will trace the steps taken by the Ministry of Foreign Affairs and Parliament which led the Netherlands to support the safe area concept with a troop contribution. We will then address the question of why the Ministry of Defence agreed to make available, despite strong reservations, a battalion of the airmobile brigade for the UN safe areas. Finally, how did 'coalition logrolling' influence the safe area mission?

\section{Military Entrapment}

Events have proven just how deadly a trap the safe area was for the Bosnian Muslim inhabitants and how deadly it might have been for the Dutch soldiers - and in the case of private Raviv van Renssen was. In terms of policy too, Srebrenica constituted a trap. Western governments had committed themselves politically and morally to the safe areas without committing themselves militarily, but then found they were stuck with them. For the Dutch government, entrapment was, however, much more acute given that its lightly armed troops were actually stationed in one of the two most vulnerable eastern enclaves. While the Dutch government's willingness to fight for the enclaves was by no means greater than that of other governments, its token military commitment to Srebrenica forced the government to keep up the pretence publicly that the mission was being carried out successfully. In reality, as soon as the Dutch peacekeepers had entered the enclave the main concern back in The Hague became how to get them out again.

An early indication that there was a gap between rhetoric and reality came even before the mission had started. In a press conference for the family of the peacekeepers about to be deployed, their commander, Lt. 
Colonel Chris Vermeulen sought primarily to encourage the audience. His task, he said, would be 'to ensure that Srebrenica ... continues to exist' and if fired upon he would 'shoot back'. His unit was well-equipped and well-prepared for the limited assignment. In reality Vermeulen was much more pessimistic, but had been urged by the Defence Ministry's department of information not to say so in public. In an interview following the press conference, Vermeulen revealed some of his pessimism: 'A massive attack by the Serbs for instance? No, the unit is not suited to withstand that. But then you get close air support ... and must trust the intelligence systems.' ${ }^{3}$

It is often argued in defence of the Dutch decision to deploy troops in Srebrenica that the Canadian government had done the same in April 1993. Such an argument overlooks two important facts. First, British, not Canadian, troops were the first to be deployed in Srebrenica. When in March 1993, the French UNPROFOR Commander, Lt.General Philippe Morillon entered the enclave, he was accompanied by a contingent of British troops in armoured personnel carriers commanded by Major Abrams. When Morillon left the enclave, he ordered Abrams and his men to stay. Nevertheless, the British subsequently quietly left the enclave, having been ordered by the Ministry of Defence in London to do so with the argument that these troops were overstretched. Secondly, the Canadian government responded to a crisis situation where speed was of the essence. It should also be noted that the Canadians and the British came to a bilateral agreement providing for close air support by British planes if the Canadian peacekeepers were to come under attack. Subsequently, the Canadian government was only interested in one thing: getting the Canadians out of Srebrenica. The Netherlands, in contrast, had had ample time to study what was now an institutionalised safe area policy and to learn from the Canadian precedent. Moreover, a Dutch United Nations Military Observer (UNMO), Colonel Van Dijk, had been part of the team accompanying Morillon in 1993. In late 1993 he gave a briefing at the Ministry of Defence - attended also by a Foreign Ministry official in which he explicitly warned against deployment in the east-Bosnian safe areas.

Adding to the sense of entrapment were the fruitless attempts by the Dutch government to break out of it. Soon after the understrength Dutch battalion had been deployed in the enclave, on March 3, 1994, key Dutch 
decision-makers recognised that they and their troops were in a mess. During a visit to the Srebrenica on May 12 Minister of Defence Ter Beek concluded that the Dutch troops had ended up in a 'triple prison'. He was forced to agree with a Dutch Major's summary of the contingent's predicament: 'The Muslim leaders here control the Muslim refugees, we guard all the Muslims and take a lot of work out of the hands of the Serbs. The Serbs guard us. ${ }^{7}$ When Joris Voorhoeve, who succeeded Ter Beek as Minister of Defence on August 22, 1994, visited the enclave ten days into his new job he reached a similar conclusion. 'I saw immediately how extremely vulnerable the enclave was to attacks by Serb troops. How exposed our soldiers were. It gave me an enormous fright and for me it was clear a solution had to be found as quickly as possible.'

Policy makers initially focused on possible ways of evacuating the Dutch battalion if the need were to arise. (Voorhoeve later explained that in 1994, when discussing his possible new job as Defence Minister, 'Srebrenica' had been discussed. At that time he believed that the safe area had in actual fact already succumbed to Serb forces in 1993. He nevertheless accepted the post, because he thought that international negotiations would lead to a solution for the population [in Srebrenica]'.) ${ }^{9}$ During the winter months of 1994 this was the single most important question occupying the Minister of Defence as well as the Second Chamber's permanent Committees for Foreign Affairs and Defence. ${ }^{10}$ On October 18 the Committees were, for instance, briefed by the army's deputy director of operations, Brigadier-General Ton Kolsteren, about the possibilities for evacuation. Unfortunately Kolsteren was forced to tell them that the withdrawal plans being worked out by UNPROFOR and NATO all pointed to the impossibility of withdrawing the Dutch troops from Srebrenica in a 'hostile environment. ${ }^{11}$ Were the Serbs to block their exit from the enclave, the Dutch would have to regroup and 'take up defensive positions within the enclave'. If a fighting withdrawal nonetheless became inevitable there were two options, both of which would certainly cost lives: a 'fly-out' and a 'drive-out'. In the first option, there was a real possibility that one or more helicopters would be lost due to hostile fire. Given that these helicopters would have to be provided by other countries, it was doubtful that such an operation would ever be undertaken. In the 'drive-out' option, the Dutch battalion would have to fight its way out, either to Serbia proper (ten kilometres), or to central Bosnia (eighty kilometres). To reach central Bosnia, the assistance of NATO forces would be 
required. Kolsteren concluded that there was only one realistic option: 'permission from the warring parties to leave in a safe way.' Kolsteren's presentation had brought home the uncomfortable truth that the bluehelmeted peacekeepers were in effect hostages.

If an evacuation from Srebrenica was not possible, the next best thing seemed to be for another country to share the Dutch plight. Predictably, the same countries that had refused to go into Srebrenica in 1993 refused again in 1994 and 1995, although it should in fairness be pointed out that a small section of British SAS soldiers (Forward Air Controllers) were with the Dutch in Srebrenica. Defence Minister Voorhoeve nevertheless put great effort into an attempt to internationalise the military presence in Srebrenica with six or seven countries. 'We asked the Poles, the Jordanians, the Argentineans and several East-European countries, but nobody wanted it.'12 The NATO countries were not enthusiastic either about Voorhoeve's proposal, made at a NATO meeting in Seville, Spain, for an 'exchange of units'. The idea was that other NATO countries would deploy troops together with the remaining Dutch in Srebrenica. The gaps in their ranks would then be filled by Dutch troops taken out of Srebrenica. Voorhoeve recalled: 'The response from our allies was: "Sorry, but we have enough on our plates already."'13 Although in June 1995 a bilateral agreement was reached with Ukraine for the replacement of the entire Dutch contingent, this commitment was largely theoretical, given the Serb blockade of the safe area.

As the situation in Srebrenica steadily deteriorated, Voorhoeve saw one option after another come to nothing. In February 1995 the Serbs shut the trap: they stopped allowing fuel to come into the enclave and began to interfere with food convoys as well as with the rotations by Dutch personnel into and out of the enclave. Voorhoeve then 'defended internationally' what he called a 'West-Berlin strategy', by which was meant an air corridor to supply the contingents in the eastern enclaves with fuel. As Kolsteren had earlier explained to parliamentarians, a helicopter operation came with daunting problems. Voorhoeve quickly discovered that the 'political will' among the other troop contributing countries to risk their helicopters being shot down 'was absent.. ${ }^{14}$ 
Another option defended by Voorhoeve constituted a preventive evacuation of the Dutch battalion and the population. However, as in 1993, this option was fiercely opposed by the Bosnian government, to whom the forty-thousand refugees stuck in dangerous Srebrenica served as a valuable object of pressure for international military intervention. 'I discussed a preventive evacuation with Ambassador Mohammed Sacirbey in October 1994, but he resolutely rejected it.' ${ }^{15}$ The two men discussed evacuation again in June 1995, but again Sacirbey would hear none of it. ${ }^{16}$ Asked whether Voorhoeve had been ready for the Dutch government not just to ask politely but to put real pressure on the Bosnian government to agree to an evacuation, he explained: 'I asked the Minister of Foreign Affairs [Hans van Mierlo] to place this option on the international agenda. I never received a written reply. In an oral reply the Minister of Foreign Affairs said that the option had been discussed before and was not politically feasible. ${ }^{17}$

The Serbs continued to play cat-and-mouse until they went in for the kill. Fortunately for the Dutch soldiers and their leaders, when the Serb attack came, the Serbs judged it wiser strategically to avoid direct combat with the Dutch UN peacekeepers and to focus instead on the elimination of the Bosnian Muslim men. Once that task had been accomplished, the Serbs released the peacekeepers from their prison, and the Dutch entrapment finally ended.

For the politicians, diplomats and generals in The Hague the experience of entrapment had been an unpleasant one - an experience they were adamant should not be repeated. The 'feelings of powerlessness' as the enclave was slowly strangled to death had turned into utter panic when the attack came: 'Whatever we thought of, there was no solution. Militarily there was nothing we could do against the Serbs. The Dutch were in the valley without cover, while above on the hilltops, the Serbian artillery and tanks stood ready. If any kind of action was undertaken, these could shoot and flatten whatever they wanted. They could easily destroy in a single blow the factory that housed the Dutch battalion. The number of victims would have been enormous. We did not stand a single chance.'18 This remark came from Lt. General Hans Couzy, who as the Commander of Land Forces had been intimately involved in the decision to deploy the airmobile brigade in the safe area of Srebrenica. 
The feverish search for a way out of entrapment and the domestic anguish after the fall of the enclave reinforce the case for examining why the Dutch had allowed themselves to get trapped in the first place. Why had there been such an eagerness to support the Security Council's safe area resolutions with a troop commitment? Why had there been no fear of deploying a Dutch infantry battalion in what Sun Tzu would have termed 'entrapping terrain'? ${ }^{19}$

\section{The Foreign Ministry and Safe Areas}

In his appearance before the TCBU parliamentary investigation committee on May 25, 2000, former Prime Minister Ruud Lubbers stated that the Foreign Ministry had been the 'driving force' behind Dutch troop deployments in former Yugoslavia. Indeed, Kooijmans insisted two years after the fall of Srebrenica that 'Srebrenica was not the wrong area [for the Dutch troops to be in], because our policy had, after all, precisely been aimed at the creation of that kind of area. The Netherlands had made a strong case for the safe areas; if it then comes to their protection, you have to take part. If you do not, you lose face. ${ }^{30}$ Clearly, Kooijmans believed that a military commitment to the safe areas was a moral and political obligation.

Military entrapment thus resulted from moral and political entrapment. The decision-making process was driven by principled beliefs concerning morality and was far removed from the rational actor decision-making model. ${ }^{21}$ The decision-making process followed the same pattern as Dutch policy regarding the ICFY peace plans, with the moral judgment often coming before the assessment. This is not just an observation made with the wisdom of hindsight, witness the warnings that were issued by a few prescient commentators at the time. When in August 1992 Minister Pronk and other politicians had called for Dutch contributions to a military intervention, Jerôme Heldring had warned that they were creating a 'climate in which irresponsible decisions are taken.'22 Pointing out that despite the 'brave words' of Ministers and MPs the Netherlands could offer 'absolutely nothing meaningful', the commentator argued that 'we should at least adapt our words to that'.

The advice to moderate the Dutch rhetoric was - as we have seen ignored. Precisely the opposite happened. A combination of personal 
ethics and domestic-political calculation tempted many politicians and officials into increasing the pressure on the only reluctant actor, the Ministry of Defence, to underpin the Dutch rhetoric with a credible contribution to the UN peacekeeping operation in the Balkans. Between August 1992 and November 1993, the number of Dutch troops deployed in and around former Yugoslavia steadily mounted to a total of 2084 soldiers. The Navy was taking part in the combined WEU/NATO blockade in the Adriatic Sea, while the Air force had deployed eighteen F16s to supervise the UN-imposed 'No-Fly Zone' over Bosnia-Herzegovina. The Army was represented with a signal battalion and a transport battalion. ${ }^{23}$

All these contributions had in common that they still did not seem sufficient to legitimise the Dutch opposition to the ICFY peace plans and the continual advocacy of military intervention. Deploying signal and transport units were judged to be low-profile and relatively risk-free operations - although four Dutch soldiers died and a substantial number were wounded while carrying them out - and not suited to increase the international credibility and visibility of Dutch policy. Caught in their rhetoric, there seemed only one way out for interventionist politicians, officials, journalists and academics alike: the deployment of a real combat unit on a 'serious' mission in Bosnia. Put bluntly, the credibility of the foreign policy elite's claims to moral virtue could only be sustained if others were willing to risk their lives. Hence the endless calls by the Foreign Ministry and by Parliament - supported by a majority of Cabinet Ministers - for additional deployments, of assembled volunteer units if necessary. 'Tank units, mechanised infantry battalions, artillery units, everything was reviewed. ${ }^{24}$ Clearly, therefore, there was always going to be great domestic pressure in favour of deploying the airmobile brigade's first operational battalion when its training would be completed.

When in May 1993 the UN Security Council formulated an expanded safe area policy, the Foreign Ministry and the Second Chamber put an end to the perceived procrastination by the Defence Ministry. On May 6, the same day the Security Council adopted resolution 824, thereby expanding the safe area policy to include a total of six Bosnian towns, the parliamentary Committees for Foreign Affairs and Defence discussed Bosnia with Kooijmans and Ter Beek. In his statement, Kooijmans told the Second Chamber that he wanted to 'promote the creation of safe areas', which he believed could be 'interpreted as a sign of international 
political will', even though there were as yet 'insufficient troops' present in Bosnia for the protection of these areas..$^{25}$ These words constituted an open invitation to the Second Chamber to put pressure on the Ministry of Defence. The invitation was accepted. Following Kooijmans' statement, all the major parties requested that the government 'contribute to a solution of the conflict in Bosnia through a speedy contribution of military units or - if that were not possible - to alleviate humanitarian suffering with military means. ${ }^{26}$ All the parties supported safe areas. There was a multi-party demand for an additional training to be given to the first soon-to-be-ready battalion of the airmobile brigade so that the Dutch could participate in their protection. ${ }^{27}$ Less than two weeks later, the Second Chamber unanimously adopted a joint Labour/ChristianDemocrat motion, which called on the government 'to also prepare the airmobile brigade for action in anticipated UN operations by giving operational battalions as quickly as possible adequate training with heavier equipment, such as armoured vehicles. ${ }^{28}$ The late Maarten van Traa (PvdA), a co-sponsor of the motion, said he believed that, despite the international reluctance to get involved, the contribution of a Dutch battalion with relief capacity should be seen as 'politically ... sufficiently important to win countries over. ${ }^{29}$

Had the Dutch government been more reluctant to raise such high expectations domestically and had it not continuously 'lectured' other countries on military intervention, it would have possessed at least two legitimate arguments for not contributing troops to the safe areas. The first would have been that the concept as formulated by the Security Council was flawed, even by the standards of a safe area supporter like the Netherlands. The second and most important argument against a Dutch troop contribution was the subsequent lack of material international support for the Security Council's safe area policy.

The resolutions being drafted in New York were 'a masterpiece of diplomatic drafting, but largely unimplementable as an operational directive.'30 These resolutions created the very ghettos Kooijmans had warned his French colleague Juppé about and certainly did not intend the safe areas to function as starting points for a phased implementation of the VOPP or any other plan. Nevertheless, by its decision to contribute troops to the safe area operation, the Netherlands had 'also effectively commit[ted] itself to the policy set out in the [Security] Council's resolutions.' ${ }^{31}$ The 
Dutch enthusiasm for the safe area policy being formulated in New York is all the more remarkable if set against the Bosnian government's more gloomy assessment. The Dutch government's frequent guest, Ambassador Sacirbey, summarised Bosnian feelings as follows: 'If you remember, the Bosnian government actually opposed the idea of the safe areas. They were artificial creations and part of the refusal to go along with the Vance Owen Plan. They served as an excuse for not intervening militarily. ${ }^{32}$

If the inherently contradictory nature of the safe area resolutions 819 (April 16, 1993), 824 (May 6, 1993) and 836 (June 4,1993) were not sufficient justification for staying far from the safe areas, then surely the subsequent absence of concrete military commitments should have set the alarm bells ringing? It would have been legitimate for the Netherlands to withdraw the offer if the government had decided thereafter that the mandate was unattainable. Such a move would not have been without precedent: in 1985 the Netherlands withdrew its contingent from Lebanon, mainly because the government and the Second Chamber judged the mandate no longer possible to fulfil - and the dangers to the Dutch peacekeepers unacceptably high (four Dutch soldiers died within the space of several months, with the total number of fatal casualties eventually rising to nine). Admittedly, the Lebanon-situation differed in that the Netherlands through participation in UNIFIL actually experienced that the peacekeeping mandate could not be fulfilled, whereas a withdrawal of the safe area troop offer would have been based, not on experience but on prior assessment. Turning this argument round, one wonders whether soldiers first have to die before a decision to withdraw a troop commitment to a peacekeeping operation becomes a legitimate one.

The question of who was going to implement the Security Council's safe area policy had become a prisoner's dilemma even before the policy had been fully formulated. In resolution 844 (June 18, 1993) the Security Council had decided on a so-called light option which required some 7600 additional troops for the safe areas. The UN Secretariat asked a great number of UN member states for troop contributions. Most member states either flatly refused or expressed a very cautious preliminary interest, the follow-up to which depended on the contributions other countries would make. Not even the five sponsors of the resolution, Russia, Spain, Britain, France and the USA, offered additional troops: an important indication that they did not believe in their own policy. ${ }^{33}$ 
The Dutch Minister of Foreign Affairs knew weeks before the Dutch troop offer was made that the US, the country that could make or break the safe area policy, refused to take part in their protection with ground troops. At their meeting on May 7 in the Netherlands Embassy in Bonn, Christopher had confronted Kooijmans with the question of whether it was wise to put soldiers in threatened cities and offer them nothing but air cover. It may have been tempting for Kooijmans to believe that the US would come round to supporting the safe areas eventually. After all, the US had just voted in favour of resolution 824 which expanded the safe area formula to six Bosnian towns. This was perhaps one of the reasons why Kooijmans, when faced with Christopher's scepticism about safe areas during their meeting in Bonn, had confidently stated that 'this option was successful in Srebrenica and thereby had proved to be a realistic approach that could be built upon'. Nevertheless, how much more explicit could Christopher have been when he warned Kooijmans that the US military thought that the option of safe areas was not militarily sound and refused to participate with ground troops? As if to underscore the point, President Clinton a few days later stated that he would not send US troops 'into a shooting gallery. ${ }^{34}$ However, clearly neither Minister Kooijmans nor his advisors were interested in such an option, with the UN Affairs Department in particular a keen supporter of a Dutch infantry contribution to UNPROFOR..$^{35}$

The Dutch government continued embracing the safe area resolutions. It had simply invested too much moral and political capital in military intervention and safe areas to be able to sell a public withdrawal from the concept. Moreover, with the adoption of resolution 824 on May 6 the Netherlands seemed to have scored a major point, for the policy it had long advocated had actually been accepted and formalised by the Security Council. Here was an opportunity to put the Netherlands on the map. The safe area resolutions, it was decided, should be capitalised upon to improve the 'visibility' of Dutch foreign policy. ${ }^{36}$

The Dutch troop commitment to the safe areas was formalised in June. On June 16, 1993, two days before the adoption of resolution 844 (when it became clear that the Security Council had opted for the light option'), an important instruction was sent to the permanent representations at the UN in New York and at NATO in Brussels. Both representations were instructed to 'announce' that the Netherlands was 'prepared in 
principle' to make an 'additional' troop contribution 'for the safe areas'. The specific contribution the Dutch government had in mind would be a 'maintenance unit' as part of a multinational 'logistical unit'. Also, they were to announce that the Netherlands 'kept open the option' to have the first battalion of the airmobile brigade 'ready for a possible deployment in Bosnia-Herzegovina from early 1994 onwards.' This offer was to be qualified with a statement that the safe areas were 'explicitly not' the battalion's envisaged assignment. Instead, they were meant for the implementation of a negotiated settlement 'on the basis of the principles of the Vance-Owen Plan'. While the troop offers were 'conditional', the intention behind them, so the instruction read, was to obtain 'maximum political effect'. The goal, as the official instruction to the Dutch Ambassadors at NATO and the UN make clear, was not just to make Dutch calls on other countries to contribute troops 'credible by setting the example oneself, but also to serve as a catalyst'. The specific offer of the airmobile brigade's first battalion was intended, moreover, 'to break the impasse' surrounding the implementation of a peace settlement. Later, when it became clear that the Dutch troop offer had failed to achieve these objectives, the Dutch government could do little else but express its 'serious disappointment about the lukewarm response by the EC partners'. ${ }^{37}$

The fact that it had agreed to the contents of the message was a sign that the pressure on the Defence Ministry from the Foreign Ministry and the Second Chamber was having an effect. The troop offers were a direct result of the two parliamentary debates in May in which Defence Minister Ter Beek had felt obliged to offer a tailor made logistical unit for the safe areas and had agreed to make the airmobile brigade ready for operations. At the same time, the fact that safe areas were excluded as an option for the airmobile brigade demonstrated that the views of Ter Beek and advisers had been taken into account. As one Defence Ministry official put it, Ter Beek's specific offer for the safe areas was made because it was seen as a relatively secure bet, since 'a logistical unit was unlikely to end up in the front-line.'38

In one remarkable paragraph, the instruction stated that for practical reasons it would not be possible to deploy both the logistical unit and the first airmobile battalion at the same time. This qualification made the rest of the message seem rather curious. For if it was not practically possible to deploy both battalions at the same time, then why were the 
permanent representations instructed to mention them both? The two Ministries each seem to have thought that this qualification fitted their policy preferences, in which case the Foreign Ministry was one step ahead. Unlike the officials in the Defence Ministry, the diplomats knew that the chance was small that the peace initiatives currently being discussed would reach the implementation phase. Part of the reason was that the Foreign Ministry itself was helping to obstruct progress with regard to the ICFY's plan for a Union of Three Republics. Hence, from the Foreign Ministry's perspective, the link between the implementation of a settlement and the deployment of the airmobile battalion seemed largely fictitious. Given that the deployment of a logistical unit was unlikely to increase the visibility of Dutch foreign policy, the conclusion appears justified that the Foreign Ministry counted on the deployment of the airmobile battalion in the framework of the UN safe area policy.

For the people in the Defence Ministry, on the other hand, the 'topic "Foreign Ministry and the peace plans" played miles away. The Foreign Ministry's stance regarding the various peace plans 'was impossible to extract. ${ }^{39}$ Somehow an excessive optimism took root in the Ministry of Defence in the summer of 1993. As Ter Beek put it, "Everywhere, the idea existed that the warring parties were battle-weary and would give preference to a compromise at the negotiating table above a second winter of war. ${ }^{\prime} 0$ As the summer wore on, the Minister, the generals and his civilian advisers convinced themselves that the UN's safe areas would be 'embedded in the approaching broader peace agreement'. ${ }^{41}$ This optimism lasted until the second week of September, when it became known that the Bosnian government had refused to accept the plan for a Union of Three Republics. Had the Defence Ministry been fully aware of the Foreign Ministry's opposition to this peace plan and the one before it, the critical line regarding infantry deployments set out by Chief of Defence Staff General Arie van der Vlis might well have remained the dominant one (see below).

One week after the instruction of June 16, the Dutch readiness for a troop offer was articulated publicly by the Cabinet itself. On June 22 Prime Minister Lubbers and Foreign Minister Kooijmans attended a European Council meeting in Copenhagen. There, Kooijmans was given a 'free hand' by Prime Minister Lubbers and announced that the Netherlands was ready to commit a logistical unit to support the UN's safe area policy. ${ }^{42}$ Through 
this commitment, the Dutch troop offer had been set in stone. As Ter Beek later put it, there now existed a potential 'loss of face' in case the Netherlands proved unable or unwilling to fulfil its promise. ${ }^{43}$

With the commitment of June 22, 1993 the Netherlands had entered the first stage of military entrapment for it was difficult to envisage how the Netherlands could still withdraw the offer, even though it had been made in relative isolation. Kooijmans and some officials later claimed that the Dutch troop commitment had been accompanied by explicit commitments by other EU member states. ${ }^{44}$ The European Council as a whole, it was argued, had agreed to assemble all of the 7600 troops needed for the safe areas. Moreover, French President François Mitterrand was said to have explicitly promised that additional French troops would take part in the implementation of the safe area policy. When the French government later withdrew the French troops from the safe area of Bihac and concentrated them in Sarajevo, the Dutch realised they had misinterpreted Mitterrand. ${ }^{45}$ Given that Sarajevo was a safe area, the French were formally still helping to implement the policy but had not deployed the additional numbers of troops Kooijmans and Lubbers believed Mitterrand had promised.

A serious look around the table in Copenhagen should have been sufficient to make one realise that it was unlikely that the Europeans would be able to assemble 7600 additional troops. Germany, Italy and Greece could or would not contribute any troops on historical and constitutional grounds. If the Netherlands had reached its limit with an additional logistical unit, then similar personnel constraints could be expected to exist in troop contributing countries like Belgium, Spain, Portugal and the Nordic countries, not to mention countries like Ireland and Luxembourg who had few, or no troops on the ground at all. Apart from the French, this left the British whose capabilities were, however, also stretched. Considerations such as these did not play a role, because the problem was approached the other way around; rather than assess what other countries would do, it was hoped that the Netherlands would serve as a catalyst. In Copenhagen 'Ruud [Lubbers] and Peter [Kooijmans] wanted to set an example. ${ }^{46}$

To summarise, while the Ministry of Foreign Affairs could claim a victory with the commitment of June 1993, the Ministry of Defence still seemed 
to be playing its hand intelligently for it had refused to be committed to the combination 'airmobile battalion and isolated safe areas'. However, between June and August 1993, as pressure on the Ministry of Defence increased further, its resistance to deploying the airmobile batallion in the safe area context gradually weakened and eventually gave way to halfhearted support.

\section{The Defence Ministry's 'Switch'}

In August 1993, the Defence Ministry 'switched' its troop offer for the safe areas from the tailor made logistical unit into an airmobile battalion. The switch seemed to imply that the Defence Ministry's attitude regarding infantry deployments and safe areas had developed from opposition to support. However, the senior officers' reservations regarding the UN's peacekeeping operation in Bosnia had not subsided. Rather, the switch was motivated by both the domestic political pressure in favour of deployment and the bureaucratic interests of the Army. According to H.J. Schoo, the editor-in-chief of Elsevier Magazine, what really caused opinion in army circles to sway in the summer of 1993 was the desire to 'justify the creation of the airmobile brigade., ${ }^{47}$

It is crucial to recognise that the Ministry of Defence was not a monolithic actor if one is to understand its changing role regarding troop deployments in Bosnia. In comparison to the Foreign Ministry, where shared beliefs had cemented various groups around a single pro-intervention perspective (albeit with differing views on the modalities of such an intervention), the Ministry of Defence was less cohesive. This was partly due to the age-old rivalry between the three armed services for as large a bite of the budgetary cake as possible. The Foreign Ministry used the divisions within the Defence Ministry to push for greater military contributions. From the perspective of a senior Foreign Ministry official 'there existed three factors at the Defence Ministry that had to be taken into account: DAB, the chief of the Defence Staff and the Commander of Land Forces. The military initially were reluctant but later changed their minds. As for Ter Beek, he too seemed to feel the need for the Netherlands to contribute something internationally. Ter Beek, like Kooijmans, appeared driven by ethics and morality.' 48 
In terms of internal cohesion, the Defence Ministry went through three stages. Between August 1992 and May 1993, there was a general reluctance within the Ministry to become deeply involved in the Yugoslav crisis. Against the pressure to deploy infantry troops the Defence Ministry initially maintained a united front. However, as the pressure continued to rise and the legitimacy of the Army budget began to be questioned, the Army leadership in particular became attracted to deployment. Once deployment began to be regarded as inevitable, the Defence Ministry's generals and civilian officials united around a shared wish to exercise as much control as possible over the actual deployment and take on a more assertive posture vis-à-vis the Foreign Ministry.

Between August 1992 and May 1993 Minister Ter Beek played a moderating role in the Dutch domestic political arena. He warned that Dutch possibilities were limited and raised practical military objections to calls for Dutch infantry contributions. He flatly refused, for instance, the idea of deploying conscripts in other than supportive roles, which made it hard to assemble complete combat units. As a consequence, Ter Beek was able to neutralise the demands for a greater Dutch military involvement by offering non-combat troops who would play a supporting role in UNPROFOR. Hence, all Ter Beek offered during the emotional exchanges of August 1992 was a unit of 400 soldiers for a joint Belgian-Dutch transport battalion (in addition to a substantial contribution by the Navy to the WEU/NATO mission in the Adriatic Sea). Given that this was double the number he had offered earlier in the year and that a signal unit was already active in Bosnia and Croatia, he could claim to be heeding the Second Chamber's calls for greater involvement. The transport battalion left for Bosnia on November 3, 1992.

The downside to Ter Beek's tactics was that nothing of what he offered could take away the widespread feeling that the Netherlands was not doing enough to help the Bosnian Muslims. Every time events in BosniaHerzegovina seemed to warrant action, calls were made for greater Dutch military contributions. In late 1992 Ter Beek deflected pressure from Lubbers and Van den Broek to do more by offering a squadron of F16s for the implementation of the No-Fly Zone. The next occasion at which the Defence Ministry came under fire was a parliamentary debate in March 1993. In the run-up to that debate Foreign Minister Kooijmans had presented Ter Beek with a fait-accompli by publicly promising additional 
Dutch troops for the eventual implementation of the VOPP. Ter Beek had not been consulted and later commented wryly that Kooijmans had 'automatically assumed that he was also speaking completely in my spirit'. ${ }^{9}$ During the actual debate, to which Ter Beek had not been invited, one MP after another came up with suggestions on how all-volunteer combat units could be assembled. Ideas that were floated included moving the Marines from the UN operation in Cambodia to Bosnia as well as the creation of a mechanised infantry battalion of volunteers drawn from different units. Kooijmans refused to commit himself but promised to review all options in a meeting with Ter Beek the day after the debate. ${ }^{50}$ Kooijmans arrived at the Ministry of Defence the next day in the company of Peter van Walsum, the Director-General for Political Affairs, and Boudewijn van Eenennaam, the director of DAV. Ter Beek awaited the delegation in the company of General Van der Vlis and Dirk Barth, the director of the General Affairs Department (DAB). Various possibilities for deploying combat units were reviewed. But Ter Beek did not commit himself and proposed instead that Van der Vlis would produce an inventory of all possible options. Van der Vlis presented his inventory on March 17, which mentioned a variety of options but clearly favoured deployment of a logistical unit of some fourhundred men. ${ }^{51}$

During a parliamentary debate on May 6,1993, when the safe area concept again stood at the centre of attention, Ter Beek pointed out that the Dutch were already making a respectable contribution to the UN operation in Bosnia, with their signal and transport battalions. He argued that there was no room for a mechanised infantry battalion. As for the first battalion of the airmobile brigade, its training would not be completed until November. 'If the necessity existed,' Ter Beek concluded, a 'tailormade' logistical unit was what the Netherlands could contribute. ${ }^{52}$ But the pressure did not subside. During another debate, on May 19, he was faced with a Labour/Christian-Democrat motion calling upon the government to prepare the airmobile brigade for operations in Bosnia. No wonder then that Ter Beek felt increasingly isolated.

A fundamental scepticism regarding the UN intervention in former Yugoslavia on the part of the senior military underpinned Ter Beek's opposition until May 1993. In addition, Ter Beek himself was concerned lest he take decisions under pressure from the 'do something' lobby that would later be judged irresponsible. ${ }^{53}$ Ter Beek's most senior adviser, 
General Van der Vlis, regarded the conflict as a potential quagmire. The nature of the conflict appeared to be complex, while the actual terrain was unfavourable to regular armies. Van der Vlis issued private and public warnings that the kind of military intervention which so many people in the Netherlands seemed to favour would be more costly than was generally suggested. He appeared, for instance, on television as early as November 1992, when safe areas were first being advocated in the Netherlands, to criticise the safe area concept and the idea of stationing peacekeepers within them. Finally, Van der Vlis feared that it would still take several years before the ethos of a true professional army would take root in the Dutch army. ${ }^{54}$ For a country whose military capability was limited it seemed, therefore, wise to adopt a low profile internationally and to keep Dutch military contributions modest..$^{55}$

Apart from military arguments such as the ones voiced by the chief of the Defence Staff, bureaucratic concerns had motivated opposition to deploying infantry. Van der Vlis and Couzy, who later claimed to have been 'a little less attached to this argument', feared that participation by the airmobile brigade in the safe area operation would compromise equipment plans. ${ }^{56}$ 'What went through my mind,' Van der Vlis later explained, 'was the question: will this not mean the end of the airmobile brigade? Because people would perhaps start saying: "See, they can work very well with armour. We don't need those helicopters." 57 The airmobile brigade was due to receive some sixty new combat and transport helicopters, an additional investment worth some two billion guilders. Without combat helicopters, the brigade would be reduced to an air-transportable infantry brigade whose added value to the Army would be questionable at best. Hence, the military became extremely concerned when in May 1993 some MPs began to hint that they might consider blocking part of the acquisition. ${ }^{58}$

Van der Vlis found himself increasingly isolated as the pressure to deploy combat troops began to fall on receptive ears within the Ministry. Two groups of players saw merit in the deployment. First, Minister Ter Beek and his civilian advisers in DAB were concerned about the political isolation in which Ter Beek found himself as a result of the barrage of parliamentary statements and motions in favour of deploying combat units. Within the Cabinet, Ter Beek later explained, 'I was virtually the only Minister trying to dissuade somewhat... Slowly a steel ring of advocates 
of an extra Dutch military contribution was closing in on me. ${ }^{59}$ Ter Beek also found himself isolated within his own party, given the strong support within the PvdA for deploying combat troops. In addition, Ter Beek, who as a socialist youth had helped to build the highway of brotherhood and unity in Tito's Yugoslavia, was touched by the same principled beliefs that motivated many other Dutch politicians, as he later acknowledged. ${ }^{60}$ Finally, the creation of the airmobile brigade had cost some six billion guilders, a sum Ter Beek had usually justified by stressing the brigade's capacity to operate in peacekeeping environments. As such he too was sensitive to calls for the brigade to show its worth. ${ }^{61}$

A second group attracted by the idea of deploying the airmobile brigade consisted of the so-called young turks. 'To his surprise', Couzy discovered that a group of officers in his own Army staff favoured additional troop contributions for the safe areas. According to Couzy, 'their argument was that it would be good for the image and presentation of the Royal Netherlands Army to carry out such a difficult assignment.' ${ }^{2}$ The 'young turks' were senior generals who believed in the need for an all-volunteer army. This made them influential, given that Ter Beek needed such modernisers to carry through the ambitious defence reforms he was overseeing. ${ }^{63}$ At the same time, they were very sensitive to parliamentary and public calls for the new brigade to show its worth. ${ }^{64}$ Their sensitivity was enhanced by the rivalry between the three armed services. ${ }^{65}$

The generals' preoccupation with the Army's and the airmobile brigade's legitimacy showed in their remarks to the press. According to LieutenantGeneral Maarten Schouten, the Commander of the First Army Corps and in 1996 successor to Couzy as the Commander of Land Forces, it would be 'very bad' for the airmobile brigade if, two and a half years after its creation it would have got 'no further than Ossendrecht heath and a little exercise in Greece. ${ }^{66}$ Another of the officers favouring the deployment of the airmobile brigade was its second successive commanding officer, Brigadier-General Jan Willem Brinkman, who told journalists that the army should do something to demonstrate that the brigade 'deserved' the yet-to-be-bought combat helicopters. ${ }^{67}$ Such was the eagerness for action among the brigade itself that Brinkman's predecessor had prepared a reconnaissance mission to Cambodia in the hope that his brigade would be ordered to replace the Marines there. When Ter Beek ordered the mission to be cancelled, the 'disappointment ... was great'. ${ }^{68}$ 
The likelihood that the airmobile brigade would be deployed in the safe area context and not in the framework of a general settlement increased dramatically in July and early August 1993 for two additional reasons. The first was an internal assessment that a deployment of the logistical unit would cause manpower problems. In July, General Schouten's First Corps let it be known that it had miscounted its personnel, as a consequence of which it was uncertain whether sufficient numbers could be found to make up the 'tailor made' logistical unit offered for the safe areas. What was certain was that deployment of the logistical unit would consume so many resources that it would no longer be possible to offer the airmobile battalion its own logistical unit. Ter Beek now risked being held responsible for a failure by the Netherlands to live up to its military commitment to the safe areas. Switching the two battalions presented itself as a politically expedient way out of this dilemma.

The second development triggering the switch was a humiliating message from the UN Secretariat in New York. On the morning of August 10, the Defence Ministry received a message from the UN that the intended assignment for the fourhundred-men strong logistical unit was the maintenance of former East-German equipment to be used by a Pakistani battalion in UNPROFOR. If the UN Secretariat's intention was to encourage the Dutch Ministry of Defence to come up with something better than a logistical unit, it could not have devised a more effective approach. For the Dutch military and their Minister, the envisaged assignment constituted an 'impossible' one. ${ }^{69}$ It was time to come up with a 'much better offer'.70

The 'switch' was formally proposed to Ter Beek by senior military and civilian advisers on August 17, 1993. Upon his return from holiday the Minister found on his desk a paper which described the problems that had arisen with regard to the deployment of the logistical unit in the framework of the safe areas. The paper proposed that the solution to these problems was to replace the tailor made logistical unit with an airmobile battalion and its own logistical support unit.

The paper's conclusions were the fruit of discussions between senior generals and civilian officials which had not, however, involved the main opponent to deployment, General Van der Vlis, who was still on holiday. In the absence of Van der Vlis, the document had been signed by his 
deputy, Lt. General Henk van der Breemen, and by Dirk Barth, the Director of DAB. Van den Breemen and Barth explained that the idea for a switch had been discussed in the regular staff meeting and that detailed consultations had been held with Lt. General Couzy and Major-General Ruurd Reitsma (the Director of Operations). While Couzy had expressed reservations, he had not rejected the proposal. Reitsma had indicated that he saw great advantages in such a switch. Upon his return, Van der Vlis was presented with a fait-accompli that was supported by everyone else with an interest. He went along with the decision grudgingly. ${ }^{71}$

In the document, Barth and Van den Breemen explained the reasons why a switch seemed the optimal decision to take. The Dutch offer of a tailor made logistical unit had run into even greater manpower problems than were known to exist before. In addition, the date for the deployment of such a unit would narrowly approach the moment when the airmobile brigade would be ready to deploy its first battalion. The problems described, the document continued, were sensitive both domestically and internationally. On the domestic side, Parliament still assumed that both battalions could be deployed. On the international level, it was clear that the Dutch political prestige had been put on the line through the Cabinet's explicit commitment in Copenhagen in June. Given that the UN Secretary-General had formally accepted the troop offer, clearly the Ministry of Defence had to come up with something. Ter Beek was given the following advice: 'Against this background we suggest you combine the offer of a logistical unit and the Dutch option of deployment of the first airmobile battalion into a new, larger Dutch offer: an airmobile battalion with its own logistical component, totalling ninehundred to thousand men. Such a battalion, equipped with YPRs [armoured vehicles] can be ready for deployment early $1994 .{ }^{32}$

There can be no doubt that the switch was made with the safe area operation in mind. Towards the end of the document, the two authors mentioned the possibility that the UN's entire safe area operation might change due to - or be overtaken by - the implementation of a settlement. 'This', the paper continued, 'inevitably brings uncertainty about the exact assignment of the extra Dutch troops to be deployed early next year.' Clearly, in this document, the safe area operation was treated as a given, and the implementation of a settlement as a possibility. 
When the ever-sceptical General Van der Vlis returned from holiday, the Defence Ministry made a final, but fruitless attempt to place the proposed switch in the context of a settlement and thereby avoid the safe areas. Minister Ter Beek was to present the new, improved offer at UN Headquarters in New York on September 7 in a meeting with UN SecretaryGeneral Boutros-Ghali. He was also to meet with senior members of the US Administration in Washington D.C. In preparation for the visit, his officials drafted a letter from Ter Beek to Boutros-Ghali, dated August 31, 1993, which reflected the unrealistic assumption that the safe area operation would be overtaken by the implementation of a peace settlement. The letter did not mention the 'safe areas' anywhere and instead argued that the new Dutch troop offer could not be 'a blanc cheque. ${ }^{73}$ The letter was handed to Jan Hoekema's UN Affairs Department in the Foreign Ministry with the request to pass it on to the permanent representation in New York, who could then pass it on to the UN Secretariat. However, the letter never reached its intended destination. Foreign Minister Kooijmans and his staff found the letter unacceptable, because it created the impression that the Netherlands was reneging on its troop contribution to the safe area operation. Defence Ministry officials were informed that the letter should be replaced by a joint instruction from both Ministries to the permanent representation in New York. The Defence Ministry caved in and agreed to a joint instruction that was sent on September 2. The telegram reminded the UN Secretariat of the commitment made in Copenhagen in June to take part in the safe area operation with a logistical unit and stated that the new offer was made with the implementation of safe area resolution 836 specifically in mind. In sum, the Foreign Ministry had kept the Defence Ministry firmly in check and had thereby determined the framework in which Ter Beek's meeting in New York would take place.

In light of what had just happened, Ter Beek could not have vetoed the safe area operation in his talks with Boutros-Ghali, had he wanted to do so: 'I very specifically committed the reinforced battalion to the implementation force but I did not explicitly say: "It is not meant for the safe areas."'74 It came as a relief when he found that Boutros-Ghali was optimistic about the likelihood of a political agreement being reached soon. In this case troops would be needed for an implementation force, rather than for a safe area operation in a war environment. More optimism came Ter Beek's way when he met US National Security Adviser Anthony 
Lake and Deputy Secretary of Defence William Perry in Washington. Lake indicated that additional European troop offers might help the US administration win over Congress for a more active involvement in the Bosnian crisis, including ground troops. ${ }^{75}$ Influenced by the optimism of his interlocutors, Ter Beek returned to the Netherlands fairly confident that the safe area operation would slip into the background as time passed by. When the Bosnian government did not accept the plan for a Union of Three Republics, it still seemed unlikely that the UN would continue the safe area operation, precisely because the UN had not been able to assemble the required number of troops. By October the Army staff had, moreover, concluded that it had a 'strong preference' for deployment in the 'area of Zenica' in central Bosnia which was close to the Dutch transport battalion's area of operation. The option Srebrenica/Zepa would pose 'great logistical problems. ${ }^{76}$ It therefore came as an unpleasant surprise when on 22 October 1993 UN Secretary-General formally requested the Netherlands to contribute the airmobile battalion to the safe area operation. According to Ter Beek, 'the absence of a peace settlement meant that the extra Dutch unit would be faced with a very different task than the one initially envisaged for it.'77

\section{The Road to Srebrenica}

The UN's request for the airmobile battalion to be made available for the safe area operation suddenly brought home the implications of the safe area policy. The enthusiasm for the safe areas that had so marked the rhetoric in the Foreign Ministry and the Second Chamber disappeared like snow before the sun with the former going so far as to suggest that there was a need for territorial exchanges involving the isolated safe areas in eastern Bosnia (see chapter 4). As for the Second Chamber, when the UN's request was made public on November 4, 1993, Christian-Democrat MP Ton de Kok telephoned the Ministry of Defence to express his concerns. De Kok indicated that he had quite a few reservations regarding the protection of the safe areas. He said he had doubts 'about the utility' of the presence of the Dutch troops inside the safe areas. He added that he was under the impression that the Dutch offer had been intended 'exclusively' for the implementation of a peace settlement. When the Defence Ministry spokesman reminded De Kok of the debates of May, 6 and 19 during which his party had strongly supported deployment of the airmobile brigade in the safe area framework, De Kok was forced to admit that 
'Parliament had perhaps somewhat very enthusiastically demanded for the preparation of the airmobile brigade.' ${ }^{78}$

Another MP to voice concern was Maarten van Traa, the PvdA spokesman for Foreign Affairs and one of the sponsors of the pro-deployment motion of May 19. Already in early October, following a visit to Bosnia, he had begun to backtrack. Van Traa told de Volkskrant: 'I have always stood in front in pleading for Dutch involvement but I now also have the responsibility to place question marks.'79 Van Traa advised his fellow party-member Gerrit Valk, the spokesman for defence affairs, to make a formal reservation during the final debate on deployment on November 16,1993 regarding the precise destination of the airmobile brigade. This Valk did, explaining that he wanted another debate when the precise location would be known. While Valk was the only one to make a formal reservation, most members of the permanent committees for Foreign Affairs and defence expressed a preference for 'stationing the battalion in a contiguous area in central Bosnia, rather than in a safe area. ${ }^{80}$ Ter Beek replied that 'he had not made an absolute condition of the choice of location' and could not exclude the possibility that the Dutch troops would be deployed in Srebrenica, although this was not his preferred choice, given the 'great logistical problems' involved. ${ }^{81}$

Given the Foreign Ministry's and Second Chamber's belated questioning of the safe area concept, it seems curious that the Ministry of Defence - rather than treating the final destination as an inevitability that was coming about by no fault of its own - did not seek to exploit the brief domestic momentum by promoting a last-ditch national effort to claim the operation in central Bosnia. Such an approach could in theory have culminated in a domestic political constellation similar to the one that had arisen in Scandinavia, where Sweden, Denmark and Norway had made available a joint 'Nordic' battalion for the safe area operation. These countries' respective parliaments opposed deployment in Srebrenica and were ready only to authorise deployment in Tuzla, a well-defended Bosnian town with a territorial link to Muslim-held central Bosnia. With the Scandinavian parliaments having taken up this position, the Swedish Foreign Minister could let it be known to the UNPROFOR Commanders that the Nordic governments opposed deployment of their battalion in Srebrenica. ${ }^{82}$ Nevertheless, the question of whether the Dutch Defence Ministry could have mobilised domestic opinion against deployment in an 
isolated safe area is not only hypothetical, but should probably be answered in the negative. The few individual expressions of doubt by MPs came too late and were too weak to resemble anything like parliamentary opposition. Ultimately, for most people the precise location and nature of the airmobile battalion's future assignment were of secondary importance. What mattered was the deployment itself. This was true for Ministers, parliamentarians, officials, officers and journalists alike. Hence, when the airmobile battalion's definitive destination became known at the end of the year, all the major parties including the PvdA supported deployment in Srebrenica.

Ter Beek sent a mission to Bosnia less than a week after the receipt by the Defence Ministry of the UN Secretary-General's request for the airmobile battalion to be made available for the safe areas. The mission was led by the commander of the airmobile brigade, Brigadier-General Jan Willem Brinkman, and included a colonel from the Defence Staff, a colonel from the Army staff and a DAB official. Brinkman was one of the 'young turks': eager supporters of deploying the airmobile brigade. The appointment of a mission leader who would have accepted most any assignment for the airmobile brigade confirmed that his superiors did not foresee tough negotations with the UNPROFOR commanders on the battalion's assignment, but rather that any assignment would be acceptable. Given that the UNPROFOR commanders were being confronted by an otherwise total refusal to deploy troops in Srebrenica, this complacent attitude on the part of the Dutch Defence Ministry increased the likelihood of Dutch soldiers ending up in an enclave that would soon be described by Ter Beek as a triple prison.

On November 9, Ter Beek and General Couzy met up with General Brinkman's delegation in Zagreb, Croatia. Brinkman told them that the UNPROFOR commanders were thinking of two options. Under the first option the battalion would be deployed in central Bosnia in the triangle Vares-Zenica-Kakanj, which was close to where the Belgian-Dutch transport battalion was based. In this case, the Nordic battalion stationed in Tuzla would also take on Srebrenica (an option that was not, as we have seen, acceptable to the Scandinavians). The second option entailed splitting the battalion into two. One half would operate in central Bosnia, the other in the Srebrenica/Zepa area, two safe areas that were considered as a single area of operation. ${ }^{83}$ Brinkman explained that UNPROFOR had a 
preference for option one. This was a relief to Ter Beek and Couzy. ${ }^{84}$ Ominously, however, Brinkman added that he considered the second option as acceptable too, which suggested that he had not raised objections to this option in his consultations with UNPROFOR. The planned meeting between Ter Beek and Lt. General Briquemont, UNPROFOR's Bosnia-Herzegovina commander, did not take place as Briquemont had gone on leave instead, thereby making it impossible for Ter Beek to express face to face his 'preference for one location in one contiguous area' ${ }^{85}$ Back in the Netherlands, nobody argued that the final decision on deployment should be postponed until Ter Beek had personally had a chance to talk to Briquemont, so on November 12 the government formally decided to deploy the airmobile brigade. Discussion in the Cabinet focused on the question of how to finance the deployment. As Ter Beek later put it, "the missionary had decided "let's go" but then the merchant asked "who is going to pay for it?".

Despite, or rather precisely because of, the uncritical support for deployment, the Dutch were still in the dark about their battalion's assignment. At the same time, the Dutch attitude helped the UNPROFOR generals in their difficult decision about which country's troops would be deployed in Srebrenica. For Cot and Briquemont a complex problem was being solved before their very eyes by a third party: if all troop contributing countries refused to deploy troops in the safe area of Srebrenica while the Netherlands did not, then Dutch troops it would be. ${ }^{86}$ Hence, when General Reitsma was sent on a reconnaissance mission to Bosnia to find out what would be the battalion's destination, the outcome had become predictable.

General Reitsma was sent to former Yugoslavia in late November with the aim of discussing the battalion's mission with General Cot in Zagreb and with General Briquemont in Kiseljak near Sarajevo. Due to bad weather, however, Reitsma was forced to stay in Zagreb and discuss the matter with Briquemont over the phone. Reitsma was told that the two options discussed with General Brinkman earlier in November had been cancelled. Instead the Dutch battalion would have to take on the safe areas of Srebrenica and Zepa. Reitsma took little convincing. Not only did he personally support deployment, but the formal decision-making process in the Netherlands had left him without any credible argument to oppose the decision by UNPROFOR. On the night of December 1 and 2, 1993, 
therefore, Reitsma faxed his report and recommendation to his immediate superior, General Couzy, who in turn forwarded it to the Defence Staff the following morning without any comment. Reitsma's message read:

The option Srebrenica and Zepa is an honourable, difficult, but do-able task for the Royal Netherlands Army and fits within the demands of the government and the wishes of Parliament. It is expected that this option will require several additional measures which are, however, not insurmountable. It is recommended to agree to this option, to inform Parliament about it and to instruct the Royal Netherlands Army to carry out this option. In order to avoid unnecessary speculations about Dutchbat's location(s) in the press and with personnel, speedy decision-making is desirable. ${ }^{87}$

The Second Chamber was informed of the location on December 3, 1993 in a letter by Ter Beek. The Second Chamber was reminded of the unanimous support they had given to the deployment decision in the debate on November 16. According to the letter there was no need for great concern for the 'military situation in both Srebrenica and Zepa [had been] quiet for some time' and the Dutch battalion could be expected to be capable of fulfilling its assignment 'well and responsibly'. ${ }^{88}$ On February 1, 1994, the Second Chamber's permanent committees for Foreign Affairs and Defence explicitly reconfirmed their consent to deployment of the airmobile battalion, whereby the national decision-making process had come to an end.

\section{The Defence Ministry Sets a Price}

While it is unlikely that a more critical attitude on the part of the Ministry of Defence could have altered the outcome, by November 1993 such was the level of acceptance within it that no serious attempt was undertaken to influence UNPROFOR's decision-making. This is not to suggest that the senior military had suddenly lost all sense of military judgment. Rather, they had come to accept that in the domestic debate on intervention, military considerations could not effectively counter political and moral considerations. Having come this far it proved impossible to avoid the temptation to go one step further and use the deployment of the airmobile battalion as a political tool. The Army leadership in particular 
began to regard the safe area mission as a costly but necessary investment, for it had identified a number of (bureaucratic) political interests such a mission could serve.

An important return on this investment, it was hoped, would be an enhanced domestic legitimacy of the Army. Given that in the Yugoslav crisis the Dutch Navy and Air force seemed to be making more important and more visible contributions than the Army, its generals became concerned that the Army's long-term financial prospects were weakening. The airmobile brigade symbolised and exacerbated the Army's predicament. The Second Chamber had only grudgingly approved its creation in 1991 and had insisted that the Minister of Defence would 'report regularly' on the progress of this expensive new unit. ${ }^{89}$ By 1993, with the Bosnian war at its height, the credibility of the new all volunteer army was at stake. The argument used traditionally by successive defence Ministers to avoid budget cuts - the real and perceived obligations to NATO - no longer worked. What the media, the Second Chamber and the Foreign Ministry made clear they wanted was for the Army and the airmobile brigade to show their worth. To reinforce the message, as we have seen, some parliamentarians went so far as to threaten blocking the funds required for the acquisition of helicopters for the airmobile brigade..$^{90}$ Hence, the Army generals concluded that 'participation' in the Bosnian operation with combat troops could act as a 'buffer against further budget cuts. ${ }^{91}$ According to Ter Beek, one general was 'absolutely' certain that Parliament would quickly come to understand the need for helicopters once the brigade's first operational battalion had been deployed in Bosnia. ${ }^{92}$

Unfortunately, by setting such a political objective, the Army leadership invited suspicion of having replaced the traditional definition of a 'successful mission' by the airmobile battalion in Bosnia by an alternative, perverse interpretation. After all, what would be a more effective demonstration of the battalion's need for helicopters than its 'imprisonment' in a surrounded enclave? While Van der Vlis had long opposed deployment of Dutch infantry in Bosnia, he now shared the Army's concern that deployment of the airmobile brigade in Srebrenica, where its battalion would be forced to operate as a mechanised infantry battalion, would compromise equipment plans. When it turned out that the Army leadership and Chief of the Defence Staff Van der Vlis advised Ter Beek to equip 
the battalion as a classic, lightly armed peacekeeping unit, some Foreign Ministry officials voiced concern. They warned their superiors that the YPR armed personnel carriers the airmobile battalion would make use of in Srebrenica, were not equipped with $25 \mathrm{~mm}$ gun turrets, but only with manually-operated .50 calibre machine guns. The official explanation, they argued, was that the airmobile brigade had not been trained for mechanised warfare and that the YPRs were only to be used as battlefield taxis. The Foreign Ministry officials, however, had also come across the argument that the Army leadership was afraid that using YPRs with 25 $\mathrm{mm}$ guns would raise further doubts in Parliament with regard to the procurement of armed helicopters..$^{93}$

While it is doubtful that the Bosnian Serbs would have allowed the more heavily armed version of the YPR to enter Srebrenica, it seems that the Army leadership eventually came to regard entrapment in an isolated safe area as a means to an end. In any case, the entrapment of the airmobile battalion in the safe area of Srebrenica helped to ensure the airmobile brigade's survival as an integral unit. Soon after the deployment in Srebrenica, parliamentary approval was given for the acquisition of transport and combat helicopters for the airmobile brigade, with D66 (opposition) leader and future Foreign Minister Hans van Mierlo commenting in May 1994 that the airmobile brigade was the only large project the government had successfully completed. ${ }^{94}$

The Defence Ministry set an additional price for its support for deployment, namely a greater say in the formulation of Dutch policy in so far as this affected the security of Dutch forces in theatre. Despite the conscious decision to equip the airmobile battalion as lightly armed peacekeepers, by no means did the Minister and the generals contemplate risking the lives of Dutch soldiers in hopeless battles for what their military judgment told them was an indefensible enclave. On the contrary, as Van der Vlis later publicly explained, the Defence Ministry had gone along with the deployment on the basis of an understanding that the Dutch soldiers would operate 'in a humanitarian mission, on the basis of impartiality' and that this 'mission would be considered terminated if the conflicting parties ceased to respect the status of the safe area and the mandate of the Dutch blue helmets. ${ }^{95}$ Ter Beek later confirmed this view: 'It was a peacekeeping operation, because we were there with the consent of the Serbs. ${ }^{\text {'96 }}$ To underscore the impartiality of the Dutch troops, they did not make an 
attempt to enter the enclave until written permission had been received from the political leader of the Bosnian Serbs, Radovan Karadzic.

Already in August 1993, a Defence Ministry steering group had concluded that the security of the Dutch forces in Bosnia-Herzegovina required that 'with every escalatory step, maximum political control must be guaranteed. ${ }^{97}$ Later, with Dutch troops stationed in Srebrenica, this meant ensuring that the use of air power would not lead to retaliation against the Dutch troops, a concern shared by other countries whose troops were placed in vulnerable positions, most notably Canada during the period that its troops had been deployed in Srebrenica. ${ }^{98}$ The responsibility for protecting the security of the Dutch troops in Bosnia-Herzegovina could not be entrusted to the Foreign Ministry, given that this concern did not seem to feature high on the Foreign Ministry's agenda. In fact, during the preceding months relations between the two Ministries had steadily deteriorated. Diplomats had come to regard the military as immoral cowards, while the military had ceased to take seriously the perceived utopians in the Foreign Ministry. ${ }^{99}$ Clearly, from the Defence Ministry's perspective, if the security of Dutch forces was to be given a central place in Dutch policy then the Defence Ministry needed to assert itself. Ter Beek later confirmed that the Defence Ministry did indeed play a more important role in the formulation of Dutch Bosnia policy following the deployment of the airmobile battalion in Srebrenica: 'Yes, oh yes, with our troops deployed in Srebrenica, our views mattered.'100

The most important consequence of the Defence Ministry's new-found assertiveness was the evolution of Dutch attitudes regarding the use of air power from enthusiasm to caution. Back in June 1993, UN Security Council resolution 836 had authorised member states to take 'all necessary measures, through the use of air power, in and around the safe areas in the Republic of Bosnia and Herzegovina, to support UNPROFOR in the performance of its mandate'. Eventually the differences of views between cautious troop contributing countries like the UK, France, Canada, Spain and - following deployment in Srebrenica - the Netherlands, on the one hand, and the more hawkish US on the other, led to a so-called dual key arrangement. This meant, in short, that NATO could not use air power without the specific permission of the UNPROFOR commanders and the UN Secretary-General or his Special Representative for former Yugoslavia. 
Before the decision to deploy troops in Srebrenica, the Dutch position regarding the use of air power had reflected the tough interventionist approach in general. The Netherlands generally favoured the use of NATO air power against the Bosnian Serbs. Thus, when there was a discussion in NATO in early August 1993 on an American proposal to threaten air strikes against Serb forces on Mount Igman near Sarajevo, the Netherlands was 'very sympathetic' towards the American proposals. Sarajevo and other safe areas 'needed to be liberated from the Serbian stranglehold'. Moreover, it was argued that the 'presence of UNPROFOR should not by itself be allowed to be an argument to exclude tougher measures by definition.' ${ }^{101}$ Similarly, during a ministerial North Atlantic Council on January 11, 1994 Kooijmans and Lubbers had called for a strongly worded paragraph on air strikes. Clearly, at this stage, the Netherlands did not yet need to fear retaliation against its own peacekeepers.

In February 1994, NATO air strikes were again threatened, this time in response to a mortar attack against Sarajevo, which had turned the town's central marketplace into a 'human abattoir'. ${ }^{102}$ While the Netherlands supported issuing a tough-sounding ultimatum to the Serbs, backed up by the threat of air strikes, it did not escape attentive journalists that the government also believed that the NATO ultimatum should be embedded in certain 'safeguards'. These safeguards entailed that no air strikes could take place without a specific request to NATO by the UNPROFOR command and the UN. De Volkskrant accurately observed : 'Kooijmans opts for caution.' ${ }^{103}$ The newspaper also commented that the new 'more balanced' Dutch policy had everything to do with the deployment of the airmobile battalion 'in Serb-controlled territory'. Fortunately, the issue dissipated as Russian intervention led to the departure of the Serb forces from Mount Igman.

One can pinpoint the moment when the Defence Ministry became more influential as an actor with regard to the use of air power. On January 19, 1994 a meeting was held in The Hague between UN Secretary-General Boutros-Ghali and Dutch Cabinet Ministers led by Prime Minister Lubbers. Air power constituted the main topic for discussion. However, Ter Beek entered the meeting with a different interest in mind than Kooijmans and Lubbers. While Ter Beek's interest was in receiving guarantees that air power would not endanger the security of the Dutch troops, Kooijmans wanted to secure a promise from the UN Secretary-General that a decision to use air power could be taken swiftly. 'I remember', 
Kooijmans later explained, 'that I exchanged detailed views with the Secretary-General about air power, whereby I made clear that there was no need for a separate decision from the Security Council to conduct air strikes. According to the Secretary-General it was necessary. That caused confusion. Lubbers agreed with me.'104

One of the reasons why Kooijmans and Lubbers seem to have been confused was that they had not made a clear distinction between 'close air support' and 'air strikes'. In the UNPROFOR environment, the distinction was nonetheless extremely important, particularly in the context of safe areas. Close air support was meant as a protective measure to be taken if UNPROFOR troops found themselves being targeted. In such a case, air power could be used to attack the actual guns threatening the UNPROFOR troops (the 'smoking gun' principle). Air strikes on the other hand were meant as a pre-emptive or punitive measure, aimed not only against tactical targets but also against such strategic targets like bridges, command centres and ammunition dumps.

In contrast to Kooijmans, Ter Beek was satisfied by the outcome of the meeting. ${ }^{105}$ The essence that he had distilled from Boutros-Ghali's words was that 'close air support' could be given on short notice, while 'air strikes' would require a more lengthy decision-making procedure. ${ }^{106} \mathrm{Ter}$ Beek's understanding of the meeting's conclusion was confirmed in a letter from Boutros-Ghali to the President of the Security Council, dated 28 January 1994. In the letter the UN Secretary General explained that the authority to invoke close air support would be delegated to his Special Representative for the former Yugoslavia, Yasushi Akashi. Air strikes, on the other hand, would require his personal approval. ${ }^{107}$

In the ensuing days, the Foreign Ministry continued to blur the distinction between the two kinds of air power while the Defence Ministry accentuated it. ${ }^{108}$ Hence, in a written exchange with the Foreign Ministry, Defence Ministry officials made clear that the blue-helmeted peacekeepers in Bosnia were not in a position to satisfy the precondition that 'an attack from the air must be finished on the ground.'109 On 27 January 1994, when the first Dutch units departed for Srebrenica, General Couzy spoke out publicly against air strikes in a radio interview. Minister Ter Beek later stated that he saw the dual key arrangement as a safety valve one should cherish rather than tamper with. ${ }^{110}$ The Foreign Ministry 
eventually caved in. Acceptance of the dual key was, as one senior DAV official put it, a 'concession by the Foreign Ministry to the Defence Ministry' (as if this was a national question). ${ }^{11}$ In fact, within the Foreign Ministry, the UN Affairs Department, as opposed to DAV, could live with the new constellation, which gave primacy to continuation of the UN's humanitarian operation over the use of NATO air power.

When in April 1994 five Dutch military observers were taken hostage by the Serbs in retaliation for the use of NATO 'close air support' over the safe area of Gorazde, the Dutch enthusiasm for the more offensive air strikes diminished further. With the hostage crisis of May 1995, when Serb forces took hundreds of UNPROFOR soldiers hostage in retaliation for air strikes against their ammunition dumps in Pale, further evidence had been provided that the combination air power and vulnerable peacekeepers in isolated enclaves was not an effective one.

Paradoxically, the Defence Ministry's cautious approach to the use of air power was supported by the parliamentarians whose primary concern now constituted the security of the very troops they had urged the Defence Ministry to deploy. Parliament's changed attitude reflected the growing doubts among the Dutch public with regard to the role of the Dutch forces in former Yugoslavia. Three opinion polls conducted between December 1993 and June 1995 demonstrated that the percentage of those in favour of Dutch participation in UNPROFOR had decreased from an absolute majority of 68 per cent in December 1993 and 53 per cent in December 1994 to 41 per cent in June 1995, albeit that the percentage of outright opponents had not substantially increased (from 14 per cent in 1993, to 26 per cent in both 1994 and 1995). ${ }^{112}$ With the initial enthusiasm for participation in UNPROFOR having waned, by June 1995, clearly the domestic balance of power had shifted in favour of the Ministry of Defence. Fatefully, by then the attempts to get the Dutch soldiers out of Srebrenica or to reinforce them had come to nothing.

\section{Conclusion}

We have argued here that Dutch entrapment in the Bosnian conflict was completed with Dutch troops being deployed as effective hostages in the enclave of Srebrenica. From then on, there was no way into and no way out of the enclave without the permission of the surrounding Serb forces. 
We have described what entrapment looked like from the perspective of the policy makers back home. Clearly, the entrapment of the Dutch troops in Srebrenica caused great concern in Dutch policy-making circles and desperate attempts were made to either free the troops from their predicament or at least to reinforce them with additional equipment or other countries' troops.

The fact that entrapment was perceived at the time for what it was begs the question of what had allowed this situation to arise in the first place. Clearly, the eventual mission for the airmobile brigade had been a more ambitious undertaking than any of the players involved in the decisionmaking had originally intended. In order to understand what led the Netherlands to offer lightly armed peacekeepers for Srebrenica one needs to separate two issues. The first would be the question of why the Netherlands supported the safe area concept as it was formulated by the Security Council. The second question is why the Netherlands agreed to the Srebrenica mission. As for the answer to the first question, it was argued that the military commitment flowed from the same moral and political considerations that had motivated the Dutch opposition to the ICFY peace plans in the first half of 1993. Having long advocated a more forceful military intervention and supported the safe area concept, the Dutch government felt morally obliged to underpin its rhetoric with deeds. Otherwise, the high moral reputation and the corresponding selfimage which the Dutch government had construed since August 1992 risked being exposed as hollow. This notion is supported by other observers. According to Koen Koch, for example, Dutch interventionism in Bosnia derived in part from such pragmatic considerations as the 'enlargement of national prestige', 'national pride' and the 'strengthening of the national self-image.' ${ }^{113}$

The second question requires scrutiny of the role played by the Ministry of Defence. There can be no doubt that until August 1993, the Defence Ministry stood isolated in its opposition to deploying Dutch infantry in the Bosnian theatre. In the face of growing domestic pressure in favour of safe areas and in favour of deploying the airmobile battalion, the Defence Ministry's position gradually shifted so that by November 1993 domestic support for deploying troops in the framework of the UN safe area policy was ' 100 per cent'. ${ }^{14}$ Apart from a sense of inevitability which the constant domestic pressure had caused, the change of policy was also 
motivated by the bureaucratic and political self-interest of the Army leadership. The main interest the Army generals sought to secure was enhanced domestic legitimacy for the Army, in particular for the expensive new airmobile brigade, which was expected to receive some sixty combat and transport helicopters. In addition, the Ministry of Defence wanted a bigger say in Dutch policy regarding the war in BosniaHerzegovina, particularly in so far as this affected the security of Dutch peacekeepers on the ground. This then was the implicit deal the Ministry of Defence offered to Parliament and the Foreign Ministry: it would go along with deployment of an airmobile battalion in the safe area framework in exchange for parliamentary approval of the acquisition of the helicopters and a greater emphasis on the security of the Dutch forces in Dutch policy towards the Yugoslav crisis. The Defence Ministry seems to have successfully protected these interests. Soon after the deployment of the airmobile battalion in Srebrencia, the acquisition of helicopters for the airmobile brigade was approved by the Second Chamber. Also, the Defence Ministry succeeded in modifying the Dutch stance regarding the use of air power over Bosnia-Herzegovina, with the Foreign Ministry having to accept a greater emphasis being put on the security of the peacekeepers. However, in their eagerness to secure these interests, the Army generals had overlooked an important point. While the Defence Ministry's official line was that the mission would be regarded as terminated were the parties to the conflict to violate Srebrenica's safe area status, both the Bosnian Muslim people in the enclave as well as the Dutch and international audience really believed that the Dutch peacekeepers could be depended upon to actually protect the Bosnian Muslims against the Serbs. In reality the peacekeepers in Srebrenica could not provide this kind of protection as anyone who had studied the UN safe area resolutions and had monitored the situation closely understood. Nevertheless, the perceived failure to protect the people in Srebrenica rebounded mercilessly on the Army and served to undermine the very legitimacy its generals had sought to secure domestically. Moreover, the Army's international reputation had suffered a huge blow.

The Srebrenica mission thus was a more ambitious mission than anyone involved in the policy-making process had intended it to be. None of the key actors apparently took into account the 'triple prison' constellation that arose when the implementation began, with General Van der Vlis as a possible exception who solved his dilemma by equipping the Dutch 
peacekeepers as lightly as possible so as to stress their peacekeeping, instead of warfighting, role. The Foreign Ministry's primary focus lay on the 'moral imperative' of an infantry contribution to the safe area operation and the 'visibility' this would bring. The Defence Ministry responded to the domestic pressure by gradually abandoning military criteria in favour of (bureaucratic) political criteria. The one strategic and moral consideration which should have stood at the centre of the decisionmaking process - but was never seriously addressed - was whether the Dutch peacekeepers would actually be in a position to afford protection to the civilian Muslim population inside the safe area.

\section{NOTES}

1 Honig and Both, Srebrenica, pp. 177-180.

2 Francis Briquemont, “Doe iets, generaal”. De val van Srebrenica bewees de leugenachtigheid van 'peacekeeping' in Bosnië' ('Do something, general'. The fall of Srebrenica proved the mendacity of peacekeeping in Bosnia), De Morgen, 9 January 1997.

3 Gow, Triumph, pp. 301-302.

4 Pauline Neville-Jones, 'Dayton, IFOR and Alliance Relations in Bosnia', in: Survival Vol. 39, No.4, Winter 1996-97, pp. 45, 46; Owen, Balkan Odyssey, pp. 277 278; LePick, 'French Perspectives', in: Danchev and Halverson, eds, International Perspectives on the Yugoslav Conflict, p. 77.

5 Anet Bleich, 'Safe havens in Bosnië: een zinnig voorstel (Safe havens in Bosnia: a sensible proposal),' de Volkskrant, November 24,1992.

6 Wio Joustra and Hans Moleman, "'Ik wil niet dat mijn mannekes risico lopen.” Commandant is in Bosnië militair èn diplomaat.' ('I don't want my men to run risks.' Commander in Bosnia is a soldier and a diplomat.), de Volkskrant, January 28, 1994.

7 Ter Beek, Manoeuvreren, p. 213.

8 Cees van der Laan, "Srebrenica laat me niet meer los". Afgeschreven Minister Voorhoeve weet niet van opgeven' ('Srebrenica does not let go of me anymore'. Written-off Minister Voorhoeve does not know how to give up) Haarlems Dagblad, February 7, 1998.

9 Joris Voorhoeve, Public Hearings, TCBU, The Hague, 31 may 2000.

10 Ter Beek, Manoeuvreren, p. 214.

11 Interview Major-General Ton Kolsteren, Utrecht, December 7, 1997. 
12 Haarlems Dagblad, 7 February 1998

13 Interview Voorhoeve.

14 Interview Voorhoeve.

15 Interview Voorhoeve.

16 Honig and Both, p. 186.

17 Interview Voorhoeve. As was described in chapter six, the Ministry of Foreign Affairs had indeed placed this option on the agenda and had been rebuffed. However, in retrospect, the refusal to try again seems to have further tied the hands of the Minister of Defence prematurely.

18 Couzy, Mijn jaren als bevelhebber, p. 153-154.

19 Sun Tzu, Art of War, p. 203.

20 Interview Kooijmans.

21 For an example of the rational actor model in foreign policy decision-making, see: Charles W. Kegley, Jr and Eugene Wittkopf, American Foreign Policy, Pattern and Process, Fourth Edition (New York: St. Martin's Press, 1991), p. 457-458.

22 Jerôme L. Heldring, 'The Breznjev-Doctrine of Jan Pronk', NRC-Handelsblad, August 25, 1992.

23 Personal File Relus ter Beek.

24 Ter Beek, Manoeuvreren, p. 179; Wio Joustra, 'Ter Beek stelt leger vredesmacht samen uit delen landmacht' (Ter Beek assembles peacekeeping force from parts of Army), de Volkskrant, March 10, 1993

25 TK), 1992-1993, 22181, no. 51.

26 Ter Beek, Manoeuvreren, p. 187

27 TK, 1992-1993, 22 181, no. 51.

28 Ibid.

29 Quoted in: TK, 1995-1996, 22 181, no. 149.

30 Shashi Tharoor, 'Should UN Peacekeeping Go "Back to Basics"?', Survival, Vol. 37, No. 4 (Winter 1995-6), p. 60.

31 D. A. Leurdijk, 'Besluitvorming in VN-verband' (Decision-making in the UN framework), D.A. Leurdijk and others, Nederland op vredesexpeditie (The Netherlands in peace expedition) (The Hague: Instituut Clingendael, 1996), p. 12.

32 Interview Muhamed Sacirbey, The Hague 17, March 1998.

33 France and Britain eventually used existing resources to help implement the policy in Sarajevo and Gorazde respectively. That said, France withdrew its troops from the safe area of Bihac. Ukraine made available additional troops, who ended up in Zepa and Gorazde, while Bangladeshi troops 'protected' Bihac. The small Canadian unit in Srebrenica had been there since April and was waiting to be replaced. The Nordic countries, finally, also offered one battalion, but vetoed Srebrenica and Zepa as areas of operation. 
34 Elisabeth Drew, On the Edge. The Clinton Presidency (New York: Simon \& Schuster, 1994), p. 162.

35 The UN Affairs Department's enthusiasm for the UNPROFOR operation, which strongly contrasted with DAV's preference for a greater NATO involvement, was highlighted by a number of the author's interlocutors.

36 TK 1995-1996, 22181, nr. 149.

37 Note from the Director of General Policy Affairs and the Deputy-Chief of the Defence Staff to Minister Ter Beek, No. D93/326, August 17, 1993, in: Personal File Relus ter Beek.

38 Interview Defence Ministry official.

39 Ibid.

40 Ter Beek, p. 190.

41 Note from the Secretary-General to the Chairman and members of the Political Council, No. S93/061/3190, October 8, 1993, in: Personal File Relus ter Beek.

42 Interview Kooijmans.

43 Ter Beek, p. 190.

44 Interview Kooijmans.

45 Note from the Deputy Director for Operational matters, Communications and Information systems, July 9,1993, in: Personal File Relus ter Beek

46 Ter Beek, p. 190.

47 H.J. Schoo, Elsevier, December 9, 1995.

48 Interview Majoor.

49 Ter Beek, Manoeuvreren, p. 178.

50 TK 1992-1993, 50, no. 20.

51 Interview Ter Beek

52 Ter Beek, Manoeuvreren, p. 188; Berghorst, Very Good News, p. 9.

53 Interview, Ter Beek. See also: Ds. Frans Jansen en Aalm. Harry Wanders, 'Het verantwoord risico. Uit liefde voor de medemens. Interview with former Minister of Defence Relus ter Beek', Kernvraag 1997/2, no. 112, pp. 19-23.

54 Interview General Arie van der Vlis, Rijnsburg, 1996 (conducted together with Dr Jan Willem Honig).

55 Interview Van der Vlis.

56 Couzy, Mijn jaren als bevelhebber, p. 138.

57 Quoted in: Berghorst, Very Good News, p. 10.

58 Cf. 'Wrevel over militaire inzet in Bosnië' (Irritation about military effort in Bosnia), NRC Handelsblad, 18 June 1993.

59 Ter Beek, Manoeuvreren, p. 184

60 Interview Ter Beek. 
61 The sum of six billion includes costs that were airmobile brigade-specific, such as the acquisition of combat helicopters and Chinook transport helicopters, as well as standing operational costs similar to those of other army brigades, such as salaries, accommodation, training etc.

62 Couzy, Mijn jaren als bevelhebber, p. 138.

63 In Ter Beek's words: 'Ruurd Reitsma belonged to the "young turks" within the army. He and the current commander Maarten Schouten really believed in the change-over of the army to an organisation with only professional personnel. They were also particularly suited for the new main task of engaging in crisismanagement operations. I was always impressed by their effort and creativity in the restructuring, in which they fulfilled an exceptionally important role.', p. 184.

64 See: Willebrord Nieuwenhuis, 'Dupe van gewijzigde realiteit. Profiel van de Luchtmobiele Brigade' (Victim of changed reality. Profile of the airmobile brigade), NRC-Handelsblad, August 9, 1997.

65 Honig, Defense policy, p. 4.

66 Quoted in: Berghorst, Very good news, p. 11.

67 Marcel Reijmerink and Perry Pierik, 'Bij Defensie dienen alsnog koppen te rollen' (Heads should still roll at Defence), de Volkskrant, September 2, 1995.

68 Ter Beek, p. 188.

69 Ibid., 191.

70 Ibid.

71 Interviews Ter Beek, Van der Vlis.

72 Note from the Director of General Policy Affairs and the Deputy-Chief of the Defence Staff to Minister Ter Beek, No. D93/326, 17 August 1993, in: Personal File Relus ter Beek.

73 Relus ter Beek, Public Hearings, TCBU, The Hague, May 24, 2000; Jan Hoekema, Public Hearings, TCBU, The Hague, May 24, 2000.

74 Interview Ter Beek.

75 Ter Beek, pp. 193-194.

76 'Aantekening inzake de uitzending van het eerste luchtmobiele bataljon naar het voormalig Joegoslavië' (Note regarding the deployment of the first airmobile battalion to the former Yugoslavia), No. S93/061/3190, in: Personal File Relus ter Beek.

77 Ter Beek, p. 195.

78 Note from Deputy Spokesman to Minister Ter Beek, November 4, 1993, in: Relus ter Beek, Personal File.

79 Van Traa twijfelt over deelname aan nieuw vredesleger' (Van Traa has doubts about participation in new peace army), de Volkskrant, October 6, 1993. 
80 Message from the Director of Operations to the Chief of the Defence Staff and SCOCIS, December 2, 1993.

81 On 15 November Ministers Kooijmans and Ter Beek informed Parliament, though the information was somewhat confusing. The letter mentioned that the UN would 'at the same time want to deploy the available military means so as to ensure that in the "safe areas" there [would] be a sufficiently large presence of UN military.' While the safe areas had thus been mentioned, according to the letter, General Briquemont's 'priority' for extra troops was 'central Bosnia', suggesting that this was where the airmobile battalion was needed most; TK 1993-1994, 22181, nr. 64 .

82 Message from the Director of Operations to the Chief of the Defence Staff and SCOCIS, 2 December 1993; Briquemont, De Morgen, January 9, 1997.

83 Interview Kreemers.

84 Minister Ter Beek was 'not unhappy' with this message: Ter Beek, p. 198.

85 Ter Beek, p. 199.

86 As General Briquemont later put it: 'In November 1993 all countries refused to station troops in Srebrenica; it really was the first time in my career as officer that I was confronted with a refusal - in the field of battle - to follow orders.' De Morgen, January 9, 1997.

87 Ter Beek, p. 203

88 TK 1993-1994, 22 181, nr. 66.

89 Honig, p. 224.

90 NRC-Handelsblad, August 9, 1997; 'Wrevel over militaire inzet in Bosnië' (Irritation about military effort in Bosnia), NRC Handelsblad, June 18, 1993.

91 Van Staden, p. 22.

92 Ter Beek, p. 191.

93 Interview Robert in den Bosch, 21 September 1999.

94 Quoted in: Ter Beek, p.180.

95 Remark made at meeting of Studium Generale, University of Utrecht, 1997

96 Interview Ter Beek.

97 'Stuurgroep. Uitgangspunten Defensie' (Steering group. Starting points [Ministry of] Defence, 23 August 1993, in: Relus ter Beek, Personal File..

98 Gow, Triumph, p. 136; Owen, Balkan Odyssey, pp. 206,225; Honig and Both, Srebrenica, pp. 106-107.

99 This picture was confirmed in the interviews and off-the-record conversations conducted by the author.

100 Interview Ter Beek. 
101 Message from the Permanent Represenation at NATO in Brussels to the Ministry of Foreign Affairs and the Ministry of Defence, August 3, 1993, in: Relus ter Beek, Personal File

102 Silber and Little, The Death of Yugoslavia, p. 309.

103 Wio Joustra, 'Kooijmans kiest voor voorzichtigheid. Navo gaat in de aanval, maar onder voorwaarden.', de Volkskrant, February 11, 1994.

104 Interview Kooijmans.

105 Interview Ter Beek; Ter Beek, p. 204.

106 When Kooijmans was confronted with Ter Beek's interpretation of the meeting of 19 January, he confirmed that his reading of the meeting had been 'different'. Source: interview Kooijmans.

107 'Letter from the Secretary-General of the United Nations to His Excellency Mr. Karel Kovanda, President of the Security Council, New York, January 28, 1994'.

108 As late as May 1994, two months after the arrival of the Dutch in Srebrenica, and after the notorious Gorazde crisis of April that year, where air power had proved to be a cumbersome tool, a Foreign Ministry official approached a Defence Ministry official with the request for an explanation on the precise difference between air strikes and close air support. Source: Interviews Ter Beek, Kreemers.

109 Memorandum from DAB-official to Minister Ter Beek, February 1, 1994, in: Relus ter Beek, Personal File.

110 Ter Beek, Manoeuvreren, p. 205.

111 Interview Foreign Ministry official.

112 Van der Meulen, 'Einde Missie?', Maatschappij en Krijgsmacht, p. 3.

113 Koen Koch, 'Zeuren aan de zijlijn' (Whinging on the sideline), de Volkskrant, July 8, 1995.

114 Interview Foreign Ministry official. 



\section{Conclusion}

This book has provided an analysis of Dutch foreign policy regarding the Yugoslav crisis from 1990 until 1995. Its main conclusion is that the Netherlands was an important and influential player in the international community's intervention in the former Yugoslavia during this period. This is a significant conclusion if one bears in mind that the Netherlands is a smaller state, or 'pocket-sized medium power', and that mainstream Realist International Relations theory assumes that smaller states have no serious role of their own to play in international affairs. A second conclusion is that the Netherlands was particularly influential during its term as EC Presidency in 1991, which suggests that it is easier for a smaller state to have an impact when its external environment is marked by a shared desire to cooperate and by respect for shared norms and rules. Third, despite the constraints imposed on the Netherlands by its external environment, domestic factors played an important, sometimes even decisive, role in determining the foreign policy behaviour of the Netherlands. In particular between August 1992 and late 1993, shared ideas and beliefs among the civilian elements of the Dutch foreign policy elite, as well as a domestic (bureaucratic) political conflict centering on the Defence Ministry's reluctance to deploy infantry in Bosnia-Herzegovina, had a decisive impact on Dutch policy. Finally, this book has highlighted the importance of distinguishing between 'influence' and 'success': between August 1992 and July 1995 the Netherlands, while influential, entrapped itself in the Bosnian war and was severely punished for it, almost as if it had violated Waltz's 'law of gravitation'. 


\section{Dutch Influence}

No evidence was found to support a claim that the Netherlands was an influential player during the period of July 1990 until June 1991, when the Yugoslav crisis had not yet descended into armed conflict. However, the question of whether the Netherlands was influential at this stage proved to be an irrelevant one for the Yugoslav crisis simply did not constitute a foreign policy concern for the international decision makers.

The situation was altogether different during the second half of 1991. Between July and December 1991 the Netherlands was at its most influential, which is not to say that the Dutch EC Presidency made no mistakes or at times failed to exert influence. What matters is that a number of specific occasions can be identified during which the Dutch Presidency played a crucial role in the formulation of EC policy. On July 7, 1991, for instance, Foreign Minister Van den Broek negotiated the Brioni declaration with the various Yugoslav sides. The declaration included a threemonth 'moratorium' on the Croatian and Slovenian declarations of independence, an agreement on access for an EC Monitoring Mission (ECMM) to Slovenia (soon thereafter extended to Croatia). Several authors, notably Silber and Little, and Meier, argue that Van den Broek had dominated the scene in Brioni. The Dutch Presidency subsequently mobilised manpower and financial resources for ECMM and had the mission deployed in Slovenia less than a month after the Brioni declaration. Interestingly, ECMM exists to this day in most of the former Yugoslavia and Albania and is currently being restructured to become a veritable common foreign policy instrument of the European Union.

It is often argued that it is much more difficult to exert 'positive' influence than it is to influence by obstruction. An example of the Netherlands influencing European policy through obstruction constituted the rejection of a French proposal in July 1991 to send a WEU-force to Croatia. Both the Netherlands and the UK argued that such a move would undermine NATO unity. (When in September that same year the Netherlands itself proposed deploying a WEU-force, it discovered that it was easier to obstruct such a proposal than to assemble sufficient support for it.)

Another important occasion on which Dutch policy impacted on the direction of the EC's approach to the Yugoslav crisis constituted the ministerial 
declaration of August 27/28, 1991. Although the draft (which had been put together by Van den Broek and Van Walsum) had been even tougher than the declaration that was eventually issued, their reference to the faitaccompli policy of Serbia and the Yugoslav army remained. This was the first time the EC member states had used such explicitly anti-Serbian language and it had the effect of strengthening the position of Croatia and Slovenia. Having referred to Serbia's fait-accompli policy, it was going to be difficult for the member states to revert back to an even-handed or neutral position.

One of the most influential actions by the Netherlands during the entire period discussed in this book, constituted the announcement on October 10, 1991 of a two-month deadline for the negotiations between the conflicting Yugoslav republics on an overall settlement. If by December 10, 1991 no agreement was reached, the EC member states would have to take a decision on a recognition of individual Yugoslav republics that wished to become independent states. Little noted at the time, this deadline nonetheless became a crucial factor in uniting the EC around a prorecognition policy. Van den Broek had presented it as a means to achieve some sort of political outcome before the end of the Dutch term as EC Presidency. While the precise nature of that outcome constituted a matter of secondary importance, Van den Broek and his advisers realised that the deadline's practical effect was to reinforce Germany's advocacy of a speedy recognition of Croatia's and Slovenia's independence.

The deadline-ultimatum was underpinned by EC policies that again showed the Netherlands to have been influential. The two-month deadline had been intended as a means of pressure on the Serbs. To add to this pressure and increase the likelihood of a political outcome before the end of the year, the Foreign Ministry employed a tactic which had originally been devised as part of the above-mentioned Dutch draft declaration of August 28. At the time it had been rejected as too imbalanced (read: antiSerbian). The idea was to distinguish between 'cooperative' and 'noncooperative' republics and, subsequently, to exclude the 'non-cooperative' republics (i.e. Serbia and Montenegro) from the all-party negotiations that were being conducted under the aegis of the EC Peace Conference chaired by the former British Foreign Secretary Lord Carrington. However, in order to be able to exclude Serbia and Montenegro from the talks, they first needed to be identified as 'non-cooperative'. The procedure 
through which this aim was achieved was based on a precise instruction, dated October 24, 1991, from Van den Broek, via Van Walsum, to Wijnaendts who served as Carrington's deputy. If Serbia and Montenegro refused Carrington's draft-settlement as it stood, then they would have identified themselves as 'non-cooperative' and would henceforth be excluded from the talks. Once that had happened, the Presidency would call together a meeting of EC Foreign Ministers and propose punitive measures against the 'non-cooperative' republics. The implication was clear: the EC would for the first time be able to discriminate between the republics with sanctions and, eventually, move for a recognition of the republics that wished to become independent. Everything went according to plan: Serbia and Montenegro refused to accept Carrington's draft. Then, on October 28, a declaration was adopted by the EC Foreign Ministers which clearly distinguished between 'cooperative' and 'non-cooperative' and threatened the latter with 'restrictive measures'. The measures were listed in a ministerial declaration on November 8. Positive compensatory measures for the 'cooperative' republics were announced on December 2. On December 12, four days before the final debate on recognition, the Netherlands distributed a telegram among its EC partners arguing that the EC member states should go ahead with recognition.

By mid-December 1991 a narrow majority of EC member states had come round to supporting a position that had been defended by Germany and Denmark from the outset. The primary impact of Dutch policy had been to serve as the glue that kept the EC more or less united around a common approach. The Netherlands had helped to prevent a German Alleingang by gradually steering the anti-recognition camp in the EC towards a more 'selective', anti-Serbian approach. While Dutch policy was not perceived to have impacted on the EC Peace Conference, it was through Dutch policy that a 'legitimate' basis was found on which to oust Serbia and Montenegro from these talks and proceed with recognition of the other republics.

The end of the Dutch term as EC Presidency did not bring to a complete halt the ability of the Netherlands as a smaller state to influence international policy regarding the Yugoslav crisis. The crisis itself developed into a new phase when in March/April 1992 war erupted in Bosnia-Herzegovina. The next occasion at which the Netherlands influenced the direction of the international community's involvement in that crisis constituted 
the London Conference of August 26-27, 1992, jointly chaired by the British EC Presidency and the UN. The tough interventionist speech made by Van den Broek at this conference achieved international fame, with Silber and Little claiming that it was the threat of the Dutch and Bosnian delegations to walk out that made the Conference adopt a declaration 'lambasting' the Serbs. Van den Broek's speech contained elements that were taken up in the Conference's 'Statement of Principles' by which any peace plan for Bosnia-Herzegovina would have to abide.

From the Dutch point of view, the peace plan that was put on the table in early 1993, the Vance Owen Peace Plan (VOPP), did not sufficiently respect the principles the Netherlands had helped to formulate at the London conference. Hence the Netherlands began to criticise and oppose it. According to one of the plan's co-authors, Lord Owen, the Dutch criticisms certainly had an impact. He argued that the Netherlands 'created very large problems for the Vance-Owen Peace Plan' and influenced the new US Administration's attitudes towards the plan. Clearly, within the EC, the Netherlands was the most critical of the VOPP. Given that the Bosnian government regarded the Netherlands as its ally and closest friend within the EU, it is likely that the Netherlands encouraged the Bosnian government not to accept the VOPP and instead to hold out for a better deal. In the process, the division caused within the EC by the Dutch stance legitimised US opposition to the plan. It seems that, apart from Bosnian Serb obstinacy which could have been overcome through imposition of the plan, it was the Bosnian-Dutch-American axis which led to the VOPP's demise.

The next peace plan on the table, the plan for a Union of Three Republics, drew a similar response from the Netherlands, which regarded as unacceptable the three-way carve-up of Bosnia-Herzegovina that was taking place. Together with Germany and the US, the Netherlands encouraged the Muslim-dominated Bosnian government to demand additional territory. Within the EU the Netherlands was the first to specifically demand four percent of additional territory to bring the total amount of territory directly under control of the Bosnian Muslims to exactly one third of the country. When France was subsequently found prepared to propose changes to this effect in a joint German-French letter to the Belgian Presidency, the Netherlands could nonetheless claim to have been one of the architects of the plan's successor, the EU Action Plan. While the EU Action 
Plan too failed, the territorial division envisaged in it, with 49 per cent of territory going to the Bosnian Serbs and the remaining 51 per cent to Croats and Muslims, was to remain the basis for the eventual settlement agreed in Dayton, Ohio in late 1995.

Another example of the Netherlands influencing the nature and direction of international Yugoslavia diplomacy involved the expansion of the UN safe area policy. The Netherlands belonged to the most vocal advocates of the safe area concept. Hence when in April 1993 Srebrenica was declared a safe area by the UN Security Council, the Dutch Foreign Ministry in particular felt vindicated. Subsequently, Foreign Minister Kooijmans pushed for an expansion of the safe area formula to other towns in Bosnia-Herzegovina, despite being warned by US Secretary of State Christopher that the US military did not believe in the concept. When the safe area concept was nevertheless further formalised and expanded by the Security Council, the Netherlands was considered instrumental in its coming about, as French Foreign Minister Alain Juppé indicated in a telephone conversation with Kooijmans in May 1993.

Through its military commitment to the isolated UN safe area of Srebrenica, finally, the Netherlands exerted influence. Apart from the fact that this move freed up Canadian troops, it is hard to deny that the Dutch commitment did indeed increase the international visibility of the Netherlands as the Foreign Ministry had envisaged. In addition, the Dutch commitment kept the safe area concept alive for the time being. But the Dutch influence was that of a double-edged sword; by keeping alive the safe area concept and its 'light option' implementation, the Netherlands helped legitimise a strategy of non-decision on the part of the Security Council, which otherwise might have been forced to seriously readdress its policy in one way or another.

\section{The External Environment:}

\section{Caught between Cooperation and Competition}

During the period of July 1990-June 1991 the Netherlands was a loyal member of various international 'regimes', in particular the EC, NATO and the OSCE. Nevertheless, this regime-dominance in the external environment was no guarantee for the Netherlands as a smaller state to exert influence on international Yugoslavia-diplomacy. This observation would 
seem to contradict the hypothesis that a smaller state is particularly well placed to be influential when the external environment is benign and cooperative. However, the evidence shows that during this period the external environment was not only benign, but also disinterested. While the early warning system functioned, as evidence regarding both the US and Dutch policy-making process demonstrates, Western governments had other problems on their minds and regarded the emerging Yugoslav crisis as an issue of secondary importance. Had the potential of the Yugoslav crisis for causing international instability been recognised at the political level at this early stage, perhaps a more decisive response would have been given. In such a case, it would have been interesting to see whether the Netherlands would have been able to play a meaningful role. What we are left with is an impression that the Dutch government all too easily settled for the middle ground in the EC, but that this criticism would be valid for most any EC member state at this juncture, given the shared wish among EC Foreign Ministers to stick to a common policy of non-interference, essentially for the sake of sticking to a common policy. Although the US regularly called upon the Europeans to do more, the US Administration too was distracted, while State Department officials found it difficult to explain what the 'more' should consist of.

The external environment in which the Netherlands formulated its Yugoslavia policy changed with the declarations of independence by Slovenia and Croatia on June 25, 1991 in that the Yugoslav crisis came to be seen as important by most Western governments. The ambition of European governments in particular grew, even though the political will to pay the military costs associated with the growing diplomatic involvement was to remain absent for years to come (prompting Gow to refer to Western diplomacy as the 'triumph of the lack of will'). From the perspective of the Netherlands the period July 1991 until May 1993 was marked by a relatively benign and cooperative international environment. In particular during the period of July-December 1991, when the Netherlands held the EC Presidency, circumstances external to the Dutch foreign policy process favoured the Netherlands. It was the EC, the international regime with the most elaborate shared rules and procedures, which took the lead in devising an international response to the Yugoslav crisis, while the US kept its distance. The EC's prominence in itself was no guarantee that a medium-powered EC member state would be able to make its mark. However, as a matter of coincidence, within the EC it was 
the Netherlands which occupied the Presidency. The combination of a prominent position within a prominent regime prepared the ground for the Netherlands to exert influence. As we have seen, the Netherlands made ample use of this opportunity. The position as Presidency not only gave the Netherlands an information advantage it would not normally have had, but obliged policy makers and decision makers to think of policies not only in terms of what was desirable from the Dutch point of view but in terms of what would be the level of acceptance among the EC partners. On occasions where insufficient attention was paid to positions of other regime-members, such as when the Netherlands proposed in July 1991 to focus on border changes, the response was immediate and harsh. Learning by doing, the Netherlands became increasingly adept at steering EC policy.

The fact that it required the 'position power' inherent in holding the Presidency for the Netherlands to be influential would seem to point to a need to seriously qualify the conclusion that a smaller state like the Netherlands is particularly well placed to exert influence in international affairs when the external environment is benign and cooperative. Of all the instances at which the Dutch Presidency was influential none would likely have occurred had the Netherlands not occupied the Presidency. It seems that more is needed, namely a prominent position within a regime, preferably one with tight rules and elaborate procedures like today's European Union. One could just as easily conclude, however, that it would have been a lot less likely for the Netherlands to have been trusted with the co-ordination of international policy in an international environment marked by competition and adversarial behaviour. From this point of view, a regime-dominated, cooperative international environment is more likely than an adversarial environment to allow for a smaller state to occupy a position of prominence.

The Netherlands still managed to exert influence in 1992 and 1993. Initially, through the EC and the International Conference on the Former Yugoslavia (ICFY), established during the above-mentioned London Conference as successor to the EC Peace Conference, the international environment remained regime-based. However, as the leading powers began to grow impatient with the established multilateral frameworks, the international environment became more multi-polar and adversarial. The growing preference for ad hoc, intergovernmental approaches to 
dealing with the Yugoslav crisis led to the announcement on May 22, 1993 by five countries of the 'Joint Action Programme' (JAP). The five JAP signatories included three EC member states, Spain, Britain and France, who had excluded the other EC member states from the process. The tendency to work through intergovernmental structures eventually culminated in the creation of the so-called Contact Group in April 1994, consisting of the US, Russia, Britain, France, Germany and, at a later stage, Italy. Other states, the Netherlands included, were thereby marginalised from the international policy process. While the development from cooperation to competition was a gradual process and should not be described in absolute terms, clearly the circumstances under which the safe area concept was institutionalised by the UN Security Council demonstrated that international solidarity had plummeted. For while the creation of safe areas had been regarded by a variety of international actors as a way to mend (mainly transatlantic) divisions, the subsequent question of who would provide troops for the implementation of the Security Council's safe area resolutions constituted a veritable prisoner's dilemma, with most governments inclined to pass the buck.

In this increasingly adversarial environment the Netherlands would inevitably find it ever harder to exert international influence. The reason why the Netherlands nevertheless succeeded in doing so on a number of important occasions lay in the new, highly visible role it had adopted. No longer the promotor of European consensus, the Netherlands took on a classic small-state posture by becoming the guardian of morality and international law. In the process many of the small-state strategies listed in the introduction were employed, in particular those with a 'normative' character. The Dutch performance at the London Conference of August 1992 and Dutch obstruction over the VOPP and the plan for a Union of Three Republics during the first half of 1993 constituted classic cases of 'demonstration politics' and '(public) criticism'. The decision to commit troops to the UN's safe area policy in the hope that the Netherlands would serve as a catalyst was a clear-cut example of 'moral guidance'.

\section{Internal factors; bureaucratic politics and principled ideas}

One cannot understand Dutch Yugoslavia policy during the period 19901995 by treating it merely as a derivative of the external constraints imposed on the Netherlands by its external environment. Domestic factors 
too were important and at times even decisive determinants. Initially, external constraints exercised by the EC and CSCE regimes were so tight that Dutch Yugoslavia policy indeed was little more than a derivative. In the Netherlands only the Foreign Ministry was oriented to a degree to what was going on in Yugoslavia, a handful of prescient academics and journalists (like NRC-Handelsblad's Eastern Europe expert, Peter Michielsen) excepted. Within the Foreign Ministry the early warning system functioned adequately. Both the embassy in Belgrade and the Eastern Europe Division in The Hague warned their superiors that Yugoslavia's disintegration was imminent. Later the Director-General for Political Affairs became concerned and called into question the existing European policy of non-interference. However, for a long time, the Minister of Foreign Affairs was not interested in the matter, essentially because his European colleagues were not either. When the interest in the topic rose, the Dutch government felt comfortable with a position at the centre of the Euro-Atlantic consensus on the need to maintain Yugoslavia's territorial integrity.

During the Dutch EC Presidency of July-December 1991, the Foreign Ministry remained the dominant domestic actor. As before, neither bureaucratic politics nor principled beliefs played a dominant role in the formulation of Dutch policy. In contrast to the preceding period however, this was due not only to external constraints but also to domestic constraints in the shape of a number of national interests, in particular the interest in continued EC-cohesion. The perceived need to maintain and promote EC-cohesion served as an exceptionally 'objective' yardstick by which Dutch Yugoslavia policy was measured. This is not to suggest that Dutch Yugoslavia policy was value-free or devoid of any view on the crisis itself, which would be inhuman, but that it was considered of paramount importance to prevent already apparent strains over the Yugoslav crisis from turning into public division. Inevitably, the existence of a relatively objective constant excluded many policy options as unrealistic or undesirable that might otherwise have gained domestic support. Only towards the end of the term as Presidency did officials begin to feel that their principled beliefs about 'good' and 'bad' were being challenged by the crisis, and such beliefs began to emerge as semi-autonomous forces in the Dutch foreign policy process. These principled beliefs did motivate some policy proposals that might have risked creating division within the EC, in particular the Dutch suggestion not to deploy a UN force in Croatia for 
fear that such a force would freeze Serbian territorial gains. However, this proposal proved to be an exception to the rule as the issue quickly disappeared from the agenda. The overall focus of the Dutch Presidency continued to be on the question of how to keep the EC member states united around a common position, which by the end of 1991 had crystallised into support for the recognition of individual Yugoslav republics as independent states.

With the end of the Dutch term as EC Presidency, the 'objective' interest in EC cohesion disappeared as an important domestic input in Dutch Yugoslavia policy. In its place came a widespread feeling of moral indignation which, although not an exclusively Dutch phenomenon, had a strong impact on Dutch policy. Principled beliefs about 'good' and 'bad', as well as the perceived moral obligation to combat evil began to make a mark on Dutch Yugoslavia policy, with public opinion, the press and Parliament as increasingly vocal actors. When confronted with the question of whether parliamentarians had not all too easily allowed themselves to be influenced by moral indignation, the late Maarten van Traa hinted at how high emotions had run in the Netherlands: 'It is easy to say in retrospect that parliamentarians should not be driven by public indignation but the daily reality was that we were being bombarded by telephone calls and letters from people asking us to do something.' something, no matter what it sometimes seemed, became the veritable driving force of Dutch Yugoslavia policy. Principled beliefs about 'good' and 'bad' lay at the origin of the Dutch opposition to the VOPP and the plan for a Union of Three Republics, the advocacy of the safe area concept and the subsequent military commitment to the UN Security Council's safe area resolutions. Only when directly confronted with the consequences, such as when the VOPP risked being replaced by a worse plan, or a failure of the EU Action Plan implied the continued existence of safe areas as 'anomalies', did the Dutch government abandon principled beliefs as the key motivation. In fact, on such occasions the Netherlands sometimes made remarkable swings from 'super-moralist' to 'superpragmatist', for instance when it suggested to European partners that a territorial exchange involving the east Bosnian safe areas might be necessary.

Bureaucratic politics quite literally played a role in the decision-making process regarding the deployment of the airmobile brigade in the safe 
area of Srebrenica. Initially the source of bureaucratic conflict, deployment of the airmobile battalion subsequently became part of a package deal along the lines of the 'coalition logrolling' model. At the centre of the initial domestic conflict stood the Ministry of Defence, the sole actor opposing deployment of Dutch infantry in advanced positions in the UN peacekeeping operation in Bosnia. Between August 1992 and August 1993, the Ministry of Defence successfully managed to resist the pressure for deployment of combat troops emanating from a broad domestic coalition spearheaded by the Foreign Ministry and the Second Chamber. Relations between the Foreign and Defence Ministries soured to the extent that an integrated civil-military perspective on the Dutch contributions to UNPROFOR was no longer possible. Instead, the diplomats focused exclusively on the moral imperative and political benefits of a deployment, while the military regarded the Bosnian conflict as a quagmire the Netherlands should stay out of. Minister of Defence Relus ter Beek cleverly bought time by regularly giving the parliamentarians something they had not asked for but dared not refuse, such as F16s, Navy frigates, a transport battalion and a signals unit. However, the downside to this tactic was that none of the commitments satisfied the advocates of deploying combat units, so that in spite of the time Ter Beek seemed to be buying, the pressure did not subside. Around the summer of 1993, Ter Beek and his advisers began to feel that the pressure could no longer be withstood without the Army's legitimacy being undermined. In particular the fact that the expensive new airmobile brigade's first operational battalion would soon complete its training would make it hard to continue opposing the deployment of combat units.

Paradoxically, once the Defence Ministry had grudgingly accepted the inevitability of deploying the airmobile brigade's first ready battalion, it appears that the Army in particular began to support the idea of deployment to the extent that its generals ceased to think critically about the nature of the battalion's mission. It seems that the generals, feeling forced to do so by the domestic-political constellation that had arisen, began to give priority to bureaucratic-political considerations over military judgment. Their change of attitude had nothing to do with a sudden change in military views on the Bosnian conflict or the safe area concept. Rather, it was primarily motivated by their concern for the domestic legitimacy of the Army, the airmobile brigade in particular. As one commentator put it, 'The Army command has never really believed in the 
doctrine of military deployment in the service of human rights. But they have never resisted the principle, because it constituted in the eyes of many the most important justification of the continued existence of large armed forces after the end of the Cold War.'2

The airmobile brigade was the jewel in the crown of the new all-volunteer Army, but it was also a very expensive unit whose envisaged airmobile tasks could not be fulfilled without helicopters. These helicopters were, however, yet to be bought. When parliamentarians, frustrated by the apparent obstinacy on the part of the Ministry of Defence, began to hint that they might be forced to block the acquisition of the brigade's helicopters, they struck a chord with the Army generals.

Apart from the Army's interest in preserving domestic legitimacy, the Defence Ministry's new-found support for deploying its first ready battalion was motivated by the view that deployment would enable the Defence Ministry to obtain a bigger say in Dutch policy regarding the war in Bosnia-Herzegovina, particularly concerning policy affecting the security of Dutch peacekeepers on the ground. Applying the coalition logrolling model, this was the 'deal' struck by the Ministry of Defence with Parliament and the Foreign Ministry: in exchange for deployment of an airmobile battalion, there was to be parliamentary approval of the acquisition of the helicopters, while Dutch policy regarding the Yugoslav crisis would henceforth be measured against its possible consequences for the security of Dutch peacekeepers. This informal deal succeeded in so far as the helicopters were indeed bought and the Defence Ministry's concern for the security of Dutch forces did indeed become a central concern of Dutch policy regarding the Yugoslav crisis. However, in the longer term the Army's international reputation and domestic legitimacy suffered a blow because of the events of July 1995.

It is striking that at a time when the views of the Foreign Ministry and Defence Ministry were so far apart, Cabinet meetings did not serve as a platform for harmonising civil and military views. Instead, it was essentially left to the Foreign Minister to formulate overall Dutch Yugoslavia policy and for him and his colleague the Minister of Defence to sort out their differences of view regarding Dutch military contributions by themselves. This is not to suggest that other Cabinet members never said anything. In fact, Christian Democrat Ministers and Social 
Democrat Ministers alike generally supported deployment, as Ter Beek suggested with his comment that in the Cabinet a 'ring of steel' slowly closed in on him. What is simply incomprehensible, however, is that until the actual fall of Srebrenica in July 1995, the Cabinet never felt inclined to discuss Dutch Yugoslavia policy in depth, as both Ter Beek and his successor Voorhoeve later lamented.

One wonders whether the civil-military dispute about the Dutch role in UNPROFOR could have been avoided in another way. First of all, it would have required a better integration of civil and military perspectives through tighter joint policy-making and decision-making procedures - for instance in the shape of a 'War Cabinet', or regular high-level meetings between the Foreign Ministry and the Defence Ministry, or regular briefings by the Defence Ministry for parliamentarians (as was the case during the Kosovo-crisis of 1999). Paradoxically, it seems that the best way of preventing the civil-military dispute of 1992-1993 would have been a very early deployment of Dutch combat troops as part of UNPROFOR, say in August 1992 when UNPROFOR was mandated by the Security Council to use force in order to ensure the delivery of humanitarian aid (resolution 770). Had such an early deployment taken place, it is possible that Dutch military views would have become an integral part of Dutch Yugoslavia policy at an early stage, akin to the situation in France, Britain and Spain. This might have helped reduce the gap between moral and political rhetoric and military reality that so obviously hampered Dutch Yugoslavia policy during this period.

As a reminder of the depth of division between the civil and the military elements in the Dutch foreign policy making circles, one needs only to look at a peculiar episode of Dutch Yugoslavia policy in the weeks following the fall of Srebrenica. In late August 1995, Prime Minister Wim Kok (who had been Minister of Finance in the preceding Cabinet) and Foreign Minister Hans van Mierlo contemplated committing Dutch troops to Gorazde, the only east-Bosnian safe area still intact. ${ }^{3}$ On August 28, the last British troops (Welch Fusiliers) stationed there had been evacuated in order to enable UNPROFOR and NATO to apply air power more freely. As Chris Vernon, the UNPROFOR spokesman at the time, put it: 'Gorazde will be defended by using the NATO airforce on a large scale on the basis of a completely different concept than up until now.' ${ }^{4}$ However, while the UNPROFOR commanders were frantically trying to evacuate 
all remaining isolated contingents of UN peacekeepers to Muslim-held central Bosnia, so as to be finally able to use air power without the risk of retaliation against these vulnerably placed troops, Prime Minister Kok said he 'absolutely could not place' the decision to evacuate Gorazde in the light of the agreement of a conference in London on June 21 to defend Gorazde. ${ }^{5}$ Foreign Minister Hans van Mierlo too believed that the decision to evacuate the enclave ran counter to the goal of defending the enclave. Both Kok and Van Mierlo apparently had not interpreted the events of the past months as evidence that the combination 'air power' and 'vulnerably placed troops' did not work. Interestingly, an opinion poll conducted in August 1995 demonstrated that the percentage of supporters for Dutch participation in military operations in the former Yugoslavia, having sunk to 41 per cent in June 1995, had bounced back to 62 per cent. ${ }^{6}$ However, having experienced Srebrenica, Defence Minister Voorhoeve vehemently opposed the idea of stationing Dutch troops in Gorazde, supported in Parliament by the VVD and the CDA. Fortunately for the Netherlands, as UNPROFOR's redeployment was completed and the air campaign began to bear fruit, it became obvious that there was no longer any point in deploying peacekeepers in Gorazde.

\section{From Indifference to Entrapment}

That one can be influential and unsuccessful at the same time was amply demonstrated by the performance of the Netherlands in the Yugoslav crisis between 1992 and 1995. In 1990, nothing yet pointed to the later entrapment of the Netherlands. In fact the Dutch government remained more or less indifferent towards the developing crisis until well into 1991. Not until the declarations of independence by Slovenia and Croatia on June 25, 1991 did Van den Broek and his European and US colleagues begin to take a greater interest in events in Yugoslavia. By contrast, during the Dutch EC Presidency of July-December 1991 Van den Broek and his senior advisers immersed themselves in the Yugoslav crisis. Nevertheless, for most of this period, the Foreign Ministry and the Cabinet seem to have kept a certain distance from the Yugoslav crisis in that it was always seen against the background of European integration. Van den Broek and his closest advisers cleverly steered clear of the Scylla of German pro-recognition pressure and the Charybdis of French/British opposition to recognition. The Netherlands successfully prevented a German Alleingang by gradually moving from 'even-handedness to 'selectiveness'. While keeping 
Germany in check, it was important at the same time to avoid the impression of undermining attempts to reach an overall settlement. The way this was eventually achieved was to impose a deadline by which time either a settlement should have been reached or else a decision made to go ahead with the recognition of Slovenia and Croatia (the only ones that really seemed to matter to the German government). With the deadline, the Netherlands could credibly encourage Germany to be patient a little while longer, while nobody could accuse the Netherlands of pre-empting a settlement although the practical effect of a deadline was, of course, to make such a settlement extremely unlikely (for there obviously no longer existed an interest for Slovenia and Croatia to make any kind of political concession). Obliged to think on behalf of the EC as a whole and with the interest in EC cohesion featuring prominently in Dutch policy, there existed little risk of the Netherlands entrapping itself in the Yugoslav crisis as the result of principled beliefs at stake in the crisis or a parochial domestic interest.

Things changed following the end of the Dutch Presidency. No longer saddled with the responsibilities associated with the Presidency, the Netherlands took up a role as guardian of international law. A lone 'principled' actor in an increasingly adversarial environment, the Netherlands gradually worked itself into a mess. On the road to the hell of Srebrenica, three stages of entrapment could be detected. First came what may be termed moral and political entrapment. Dutch politicians, diplomats and journalists explicitly committed themselves to the defence of certain moral principles through military means. Hence the Dutch call to arms at the London Conference of August 1992; hence the Dutch opposition to the VOPP; hence the opposition to the plan for a Union of Three Republics; hence the support for an instutionalised UN safe area policy in Bosnia-Herzegovina; hence the Dutch troop offer for the safe areas. Throughout this period, the Dutch foreign policy elite had paid little attention to the question of whether adequate Dutch military means were available at a time when the Dutch Army was still in the process of changing from a conscript-based Army into an all-volunteer Army. They had not paid attention to an even more important question either, namely whether a willingness to pay the military costs associated with the protection of moral principles truly existed in the Netherlands. Having thus created a gap between moral rhetoric and the reality of the Dutch military role in UNPROFOR, the foreign policy elite were faced with the question 
of how to close the gap. Either the rhetoric had to be adapted to the Dutch military role, or alternatively the Dutch military contribution would have to be beefed up so as to bring it in line with the rhetoric. The Dutch foreign policy elite opted for the latter, which explains the consistent pressure on the Defence Ministry to come up with something better than the F16s and the frigates, something better than the transport battalion and something better than the signals unit.

Dutch military entrapment in the Yugoslav crisis took shape when on June 22, 1993 the government committed itself internationally to an additional military contribution for the specific purpose of implementing the UN Security Council's safe area policy. Having consistently occupied the moral high ground internationally, to withdraw this commitment would have meant the end of the Dutch role as guardian of morality. In February 1994, a first Dutch troop contingent entered the Srebrenica enclave, with the remainder of the (understrength) battalion arriving in March. As soon as they were inside the enclave, the implications became clear. When parliamentarians were briefed by Dutch military on the situation, they realised that the Dutch peacekeepers in Srebrenica were the hostages, if not prisoners, of the surrounding Serbs. The domestic alliance between the Foreign Ministry and Parliament quickly gave way to an understanding between the Defence Ministry and Parliament that the security of the Dutch forces was paramount and that the use of NATO air power was not to result in retaliation against the vulnerable Dutch peacekeepers. The Foreign Ministry only grudgingly accepted the Defence Ministry's leadership with regard to the question of air power. The fall of Srebrenica was to trigger an anguished debate in the Netherlands, with a lot of unfair scapegoating directed at the Dutch battalion in Srebrenica and Defence Minister Voorhoeve. In reality, while moral indignation was a huge driving force both before and after the fall of Srebrenica, the decision-making process regarding the deployment of the battalion had omitted to address the most important question of all, namely whether the Dutch peacekeepers would be in a position to offer effective protection to the Muslim population in the enclave and, if not, what was the morality of deploying them. 


\section{NOTES}

1 [Het is achteraf makkelijk praten als men zegt dat parlementariers zich niet zo moeten laten meesslepen door publieke verontwaardiging, maar de dagelijkse realiteit was dat we werden bestookt met telefoontjes en brieven van mensen die wilden dat we iets deden.]: Maarten van Traa in public debate during book presentation Dick Leurdijk, Pulchri, The Hague, 1997.

2 Paul Scheffer, NRC-Handelsblad, September 4, 1995.

3 TK 1993-1994, 22 181, no. 119.

4 VN laten "veilige haven" Gorazde aan lot over' (UN abandon 'safe haven' Gorazde to its fate), Trouw, August 26, 1995.

5 'Kok ontkent meningsverschil over Gorazde' (Kok denies difference of opinion over Gorazde), ANP, August 25, 1995.

6 Stichting Maatschappij en Krijgsmacht, Internet site: www.smk.nl. 


\title{
Bibliography
}

\author{
PRIMARY SOURCES
}

\section{Unpublished Official Documents}

Archief Buitenlandse Zaken, The Hague

Aim: ddi-deu / ara / 01990, 1992-1992, Kroatie / Nederland / diplomatieke betrekkingen / erkenning van staten.

Aim: ddi-deu /ara / 00039, 1991, Berichtgeving van de posten m.b.t. de binnenlandse politiek van Joegoslavie.

Aim: dpv /ara / 00812, 1993-1993, International Conference on the Former Yugoslavia (ICFY) Vance-Owen Peace Plan.

Aim: ddi-deu /ara / 01311, 1993-1993, Vredesmachten / Internationale bemiddeling. Dossier inzake het analyseren en becommentariëren m.b.t. de implementatie van het Vance-Owen plan in Bosnië-Hercegovina.

Aim: dpv /ara / 00811, 1993/02, International Conference on the Former Yugoslavia (ICFY).

Aim: ddi-deu /ara / 00753, Europese Unie / Actie-Plan. Dossier inzake de informatieverstrekking m.b.t de relatie tussen Bosnië-Hercegovina en de Europese Unie m.b.t. de follow up Actie-Plan in Bosnia-Hercegovina.

Aim: ddi-deu / ara / 02157, 1994, Dossier inzake de informatieverstrekking m.b.t. de relatie tussen Bosnië-Hercegovina en de EU m.b.t. de follow-up Actie-Plan in Bosnië-Hercegovina

Aim: ddi-deu / ara / 00077, 1991-1991, DEU / Berichtgeving van de posten m.b.t. de binnenlandse politiek van Joegoslavië. 
Aim: ddi-deu / ara / 00430, 1991-1991, Joegoslavië / Verhoudingen en diplomatieke betrekkingen met Nederland.

Aim: ddi-deu / ara / 00823, 1991-1991, Dossier inzake de advisering m.b.t. het te vormen beleid t.a.v. de binnenlandse poitieke crisis in Joegslavië.

Aim: ddi-deu /ara / 00430, augustus-december 1991, Joegoslavië / Verhoudingen en diplomatieke betrekkingen met Nederland.

Aim: die / 1985 - 1994 / 01248 / november 1991 - januari 1992, Europese gemeenschappen / EG / Joegoslavië.

Aim: ddi-deu / ara / 03310, september 1991, De verhouding tussen de FRJ (Servië/Montenegro) en de Verenigde Naties (VN) m.b.t. de International Conference on the Former Yugoslavia (ICFY).

Aim: ddi-die / ara / 01233, 1985 - 1994, Europese Gemeenschappen / EG / Joegoslavie.

Aim: ddi-deu / ara / 1232, september-oktober 1991, Europese Gemeenschappen / EG / Joegoslavië.

Aim: ddi-deu / ara / 03290, oktober-december 1991, De verhouding tussen de FRJ (Servië/Montenegro) en de Verenigde Naties (VN) m.b.t. de International Conference on the Former Yugoslavia (ICFY).

Aim: ddi-deu /ara / 00411, oktober-december 1991, Deu / Berichtgeving d.m.v. coreus inzake de standpunten van de europese politieke samenwerking over Joegoslavië.

Aim: ddi-deu /ara / 00404, oktober - december 1991, DEU / berichtgeving van de posten m.b.t. de binnenlandse politiek van Joegoslavië inzake Kroatië.

Aim: ddi-die / ara / 1082, januari 1990 t/m mei '91, EG Verhouding met Joegoslavie.

Provinciehuis, Assen

Relus ter Beek’s personal papers, 1989-1994.

\section{Other}

Wijnaendts, Henry. Memorandum no. 5, October 10, 1991, situation report. Document of the EC Peace Conference. 


\section{Dutch Government Publications and Other Published Official Documents}

TK, 1979, 15 441, nr.7, 'Nederlandse deelneming aan de VN vredesmacht in Libanon. Om niet dan na overleg met de Kamer aan een VN vredesmacht deel te nemen.'

TK, 1979, 15 887, nr. 6, 'Modernisering kernwapens.'

TK, 1990-1991, 21 813, nr. 2, 'Nieuwe kaders voor ontwikkelingssamenwerking in de jaren negentig. Een wereld van verschil.'

TK 1991-1992, 22 181, nr. 20, 'De situatie in Joegoslavië, Verslag van een mondeling overleg.'

TK, 1992-1993, 53, nr. 20, 'Aan de orde is de behandeling van de brief over de situatie in voormalig Joegoslavië en de opvang van vluchtelingen (2281, nr. 35).'

TK, 1992-1993, 22181, nr. 46, 'De situatie in voormalig Joegoslavië. Brief van de Minister van Buitenlandse Zaken en de Minister van Defensie.

TK, 1992-1993, 22 181, nr. 51, 'De situatie in voormalig Joegoslavië. Verslag van een mondeling overleg.

TK, 1992-1993, 22 975, nr. 1-2, 'Prioriteitennota: Een andere wereld, een andere Defensie.'

TK, 1993-1994, 22 181, nr. 52, 'De situatie in voormalig Joegoslavië. Verslag van een mondeling overleg.'

TK, 1993-1994, 22 181, nr. 66, 'De situatie in voormalig Joegoslavië. Brief van de Minister van Defensie.'

TK, 1994-1995, 23 591, nr. 5, 'Betrokkenheid van het parlement bij de uitzending van militaire eenheden. Brief Ministers met notitie over het toetsingskader voor uitzending van militaire eenheden voor internationale operaties.'

TK, 1996-1997, 22 181, nr. 49, 'De situatie in voormalig Joegoslavië. Brief van de Minister van Buitenlandse Zaken.'

TK, November 15, 1993, 1993-1994, 22181, No. 64.

\section{Other Published Documents}

Adviesraad Vrede en Veiligheid. Verloren onschuld. Nederland en VN-operaties.

Keerpunt 1972. Regeerakkoord van de progressieve drie (PvdA, D'66 en PPR). 1972.

Kemenade, Dr J.A. Omtrent Srebrenica. Rapport over de verzameling en verwerking van informatie door de defensie-organisatie over gebeurte- 
nissen rond de val van de enclave Srebrenica, eindrapport en bijlagen, september 28, 1998.

Report of the Secretary-General pursuant to General Assembly Resolution 53/35 (1998) 'Srebrenica Report', November 15, 1999.

The United Nations and the Situation in the Former Yugoslavia. Resolutions of the Security Council and Statements by its President, September 25, 1991-April 28, 1995. New York: UN Department of Public Information, April 1995.

Scheffer, P. 'Machtsverschil en rechtsgelijkheid in de Europese Unie', Wetenschappelijke Raad voor het Regeringsbeleid. Werkdocumenten. W 86, 1995.

Stichting Wetenschappelijk Bureau D'66. 'Nieuwe Prioriteiten in het Buitenlands Beleid,' SWB Cahier, Vol. 4, No. 1, 1995.

\section{Published Memoirs and Diaries}

Baker, James A. III with Thomas M. DeFrank. The Politics of Diplomacy. Revolution, War \& Peace, 1989-1992. New York: G.P. Putnam's sons, 1995.

Beek, Relus ter. Manoeuvreren. Herinneringen aan Plein 4, Amsterdam: Balans, 1996.

Bell, Martin. In Harm's Way. Reflections of a War-Zone Thug. London: Penguin, 1996.

Bildt, Carl. Peace Journey. The Struggle for Peace in Bosnia. London: Weidenfeld and Nicolson, 1998.

Couzy, H.A. Mijn jaren als bevelhebber. Amsterdam: L.J.Veen, 1996.

Dutchbat on Tour. Juli '94 - Januari '95, Delft: Début.

Dutchbat in Vredesnaam. Januari 1995 - juli 1995. Rijswijk: Début, 1996.

Genscher, Hans-Dietrich. Erinnerungen. Berlin: Siedler Verlag, 1995.

Heuven, Marten van. 'Yugoslavia: what issues? what policies?' Remarks to the Washington Institute of Foreign Affairs,' The Cosmos Club, Washington, D.C., February 4, 1993, RAND / P-7808, February 1993.

Holbrooke, Richard. To End a War. New York: Random House, 1998.

Karremans, Srebrenica. Who Cares? Nieuwegein: Arko, 1998.

Morillon, Général. Croire et Oser. Chronique de Sarajevo. Paris: Grasset, 1993.

Owen, David. Balkan Odyssey. London: Gollancz, 1995; Balkan Odyssey, CD ROM. 
Plas, Michel van der. Luns: 'ik herinner mij...' Vrijmoedige herinneringen van Mr. J.M.A.H. Luns zoals verteld aan Michel van der Plas. Leiden: A.w. Sijthoff, 1971.

Veenhof, Herman, Srebrenica, Oorlogsdagboek van Piet Hein Both. Barneveld: De Vuurbaak, 1995.

Westerman, Frank. De brug over deTara. Amsterdam: Atlas, 1994.

Wijnaendts, Henry. Joegoslavische Kroniek Juli 1991 - Augustus 1992, Amsterdam: Rap, 1993.

White Dragon. The Royal Welch Fusiliers in Bosnia. Wrexham: The Royal Welch Fusiliers, 1995.

Zimmerman, Warren. Origins of a Catastrophe: Yugoslavia and Its Destroyers. New York: Times Books, 1996.

\section{SECONDARY SOURCES}

\section{Books}

Allison, Graham. Essence of Decision. Explaining the Cuban Missile Crisis. Boston: Little, Brown, 1971.

Baker-Fox, Annette. The Power of Small States, Diplomacy in World War II. Chicago and London: The University of Chicago Press, 1959.

Banac, Ivo. The National Question in Yugoslavia. Origins, History and Politics. Ithaca, New York: Cornell University Press, 1984.

Behschnitt, Wolf Dietrich. Nationalismus bei Serben und Kroaten 18301914. München: Oldenburg Verlag, 1980.

Bloed, Arie, ed., The Conference on Security and Cooperation in Europe. Analysis and Basic Documents, 1972-1993. Dordrecht: Kluwer, 1993

Bloed, A. and P. van Dijk, eds., The Human Dimension of the Helsinki Process. Dordrecht: Kluwer, 1991.

Blom, J.C.H. Crisis, Bezetting en Herstel. Tien Studies over Nederland 19301950. The Hague: Universitaire Pers Rotterdam, 1989.

Bodenheimer, Susanne. Poltical Union. Microcosm of European Politics 1960-1966. Leiden: 1967.

Boxer, C.R. The Dutch Seaborne Empire 1600-1800. London: Penguin, 1990. Cahill, Kevin M. M.D., ed. Preventive Diplomacy. Stopping Wars Before They Start. New York: Basic Books, 1996. 
Calic, Marie-Janine. Der Krieg in Bosnien-Hercegovina. Ursachen, Konfliktstrukturen, Internationale Lösungsversuche. Frankfurt am Main: Suhrkamp Verlag, 1995.

Carlsnaes, Walter and Steve Smith, eds. European Foreign Policy. The EC and Changing Perspectives in Europe. London: SAGE, 1994.

Carr. E.H. The Twenty Years' Crisis 1919-1939. London: MacMillan, 1995.

Cohen, Lenard. Broken Bonds. Yugoslavia's Disintegration and Balkan Politics in Transition, Second edn. Boulder, Colorado: Westview Press, 1995.

Clarke, Michael and Brian White. Understanding Foreign Policy. The Foreign Policy Systems Approach. Aldershot: Edward Elgar, 1989.

Danchev, Alex and Thomas Halverson, eds. International Perspectives on the Yugoslav Conflict Oxford/London: MacMillan and St. Antony's College Oxford, 1996.

Dosenrode-Lynge, von, Sören Zibrandt, Westeuropäische Kleinstaaten in der EG und EPZ Zürich: Rüegger, 1993.

Drew, Elisabeth. On the Edge. The Clinton Presidency. New York: Simon \& Schuster, 1994.

Dürrenmatt, Peter. Der Kleinstaat und das Problem der Macht. Basel: Helbing und Lichtenhahn, 1955.

Eekelen, Willem van. Debating European Security, 1948-1998. The Hague, Brussel: Sdu Publishers / Centre for European Policy Studies, 1998.

Everts, Philip and Guido Walraven, eds. The Politics of Persuasion. Implementation of Foreign Policy by the Netherlands. Aldershot: Gower, 1989.

Fisher, Herbert. Studies in History and Politics. Oxford: Clarendon Press, 1920.

Freedman, Lawrence, ed. Military Intervention in European Conflicts. Oxford: Blackwell Publishers / The Political Quarterly, 1994.

George, Stephen. Politics and Policy in the European Union, second edn. Oxford: University Press, 1991.

Gilpin, Robert. War and Change in World Politics. Cambridge: University Press, 1981.

Glenny. Misha. The Rebirth of History. Eastern Europe in the Age of Democracy. London: Penguin Books, 1990.

Glenny, Misha. The Fall of Yugoslavia, new edition. London: Penguin Books, 1993.

Goldstein, Judith and Robert O. Keohane. Ideas \& Foreign Policy. Beliefs, Institutions and Political Change. Ithaca: Cornell University Press, 1993. 
Gow, James. Triumph of the Lack of Will. International Diplomacy and the Yugoslav War. London: Hurst, 1997.

Griffiths, Richard T., ed. The Netherlands and the Integration of Europe 1945-1957. Amsterdam. NEHA-series III, 1990.

Habeeb, William M. Power and Tactics in International Negotiation. How Weak Nations Bargain with Strong Nations. Baltimore / London: Johns Hopkins University Press, 1988.

Halperin, Morton. Bureaucratic Politics \& Foreign Policy. Washington D.C.: Brookings Institution, 1974.

Handel, Michael. Weak States in the International System. London: Frank Cass, 1981.

Hayes-Renshaw, Fiona and Helen Wallace. The Council of Ministers. London: MacMillan, 1997.

Hellema, Duco. Buitenlandse politiek van Nederland. Utrecht: Aula, 1995.

Heuvel, Martin van den and Jan G. Siccama, eds. Yearbook of European Studies 5. The Disintegration of Yugoslavia. Amsterdam: Rodopi, 1992. Hill, Christopher, ed. The Actors in Europe's Foreign Policy. London: Routledge, 1996.

Hoffmann, Stanley. Gulliver's Troubles, or the Setting of American Foreign Policy. New York: McGraw-Hill, 1968.

Honig, Jan Willem. Defense Policy in the North Atlantic. The Case of the Netherlands. Westport Connecticut/London: Praeger, 1993.

Honig, Jan Willem and Norbert Both. Srebrenica. Record of a War Crime. London: Penguin Books, 1996.

Huys, Twan. In opdracht van Hare Majesteit; Diplomat in a time of crisis. Weert: M\&P, 1994.

Jansen, Thomas. Die Entstehung einer Europäischen Partei: Vorgeschichte, Gründung und Entwicklung der EVP. Bonn: Europa Union Verlag, 1996.

Judah, Tim. The Serbs: History, Myth and the Destruction of Yugoslavia. New Haven and London: Yale University Press, 1997.

Kaplan, Robert. Balkan Ghosts: A Journey through History. New York: Vintage Books, 1993.

Kegley, Charles W. Jr. ed. Controversies in International Relations Theory. Realism and the Neoliberal Challenge. New York: St. Martin's Press, 1995.

Kegley, Charles W. Jr. and Eugene Wittkopf. American Foreign Policy, Pattern and Process, Fourth Edition. New York: St. Martin’s Press, 1991. 
Keohane, Robert O. ed. Neorealism and its Critics. New York: Columbia University Press, 1986.

Keohane Robert O, and Joseph Nye. Power and Interdependence. Boston and Toronto: Little, Brown, 1977.

Kissinger, Henry A. A World Restored. Castlereagh, Metternich and the Restoration of Peace, 1812-1822. Boston: Houghton Mifflin, 1957.

Kooijmans, P.H. Internationaal publiekrecht in vogelvlucht, 6th edn. Groningen: Wolters-Noordhoff, 1996.

Leeuwen, van, M. et al. Het Woord is aan Nederland. Thema's van buitenlands beleid in de jaren 1966-1983. The Hague: Sdu, 1983.

Leurdijk, Dick A. The United Nations and NATO in Former Yugoslavia, 1991-1996. Limits to Diplomacy and Force. The Hague: Netherlands Atlantic Commission / Netherlands Institute of International Relations 'Clingendael', 1996.

Leurdijk, D.A. et al. Nederland op vredesexpeditie. The Hague: Instituut Clingendael, 1996.

Libal, Michael. Limits of Persuasion. New York: Praeger, 1998.

Little, Richard and Michael Smith. Perspectives on World Politics, second edn. London: Routledge, 1991.

Lodge, Juliet, ed. The European Community and the Challenge of the Future, $2^{\text {nd }} e d n$. London: Pinter, 1993.

Lotringen, van, Cees. De kwetsbare kolos. De gevaren van een zwak Duitsland. Amsterdam/Antwerpen: Veen, 1995.

Lyddal, Harald. Yugoslavia in Crisis. Oxford: Clarendon Press, 1989

Malcolm, Noel. Bosnia. A Short History. London: MacMillan, 1994.

Meier, Viktor. Wie Jugoslawien verspielt wurde. München: Beck, 1996.

Middlebrook, Martin. Arnhem 1944. The Airborne Battle. (London: Penguin Books, 1995)

Nooy, Gert de, ed. The Clausewitzian Dictum and the Future of Western Military Strategy. The Hague: Kluwer Law International, 1997.

Olson, William C. and A.J.R. Groom. International Relations Then \& Now. Origins and Trends in Interpretation. London: Routledge, 1992.

Oye, Kenneth A., ed. Cooperation under Anarchy. Princeton N.J.: Princeton University Press, 1986.

Purnell, Robert. The Society of States: An Introduction to International Politics. London: Weidenfeld and Nicolson, 1973.

Rabin, Yihtzak. The Rabin Memoirs, 2nd. edn. Bnei Brak, Israel: Steimatzky, 1994. 
Raeymaeker, Omer de, et al. Small Powers in Alignment. Leuven: University Press, 1974.

Randal, Jonathan C. After Such knowledge. What forgiveness? New York: Farrar, Straus and Giroux, 1997.

Rittberger, Volker, ed. Regime Theory and International Relations. Oxford: Clarendon Press, 1993.

Roer, van de, Robert. Frontdiplomaten. Confrontaties met internationale hoofdrolspelers. Amsterdam: Balans, 1999.

Rohde, David. A Safe Area. Srebrenica: Europe's Worst Massacre Since the Second World War. London: Pocket Books, 1997.

Röling, Mr. B.V.A. Volkenrecht en vrede, 3rd edn. Deventer: Kluwer, 1985.

Rosenthal, U. Bureaupolitiek en bureaupolitisme: om het behoud van een competitief overheidsbestel. Alphen aan den Rijn: Samsom, 1988.

Rothstein, Robert L. Alliances and Small Powers. New York and London: Columbia University Press, 1968.

Sas, N.C.F. van, ed. De kracht van Nederland. Internationale positie en buitenlands beleid in historisch perspectief. Haarlem: Becht, 1991.

Scheffer, Paul. Een tevreden natie. Nederland en het wederkerend geloof in de Europese status quo. Amsterdam: Bert Bakker, 1988.

Silber, Laura and Allan Little. The Death of Yugoslavia, revised edn. London: Penguin Books / BBC Books, 1996.

Snyder, Jack. Myths of Empire. Domestic Politics and International Ambitions. Ithaca and London: Cornell University Press, 1991.

Soetendorp, R.B. and A. van Staden, eds. Internationale betrekkingen in perspectief. Utrecht: Spectrum, 1987.

Staden, A. Van. Een trouwe bondgenoot: Nederland en het Atlantisch bondgenootschap 1960-1971. Baarn: In den Toren, 1974.

Thompson, Mark. A Paper House. The Ending of Yugoslavia. London: Vintage/Arrow, 1992.

Tzu, Sun. Art of War, Translated, with a historical introduction by Ralph D. Sawyer. Boulder: Westview Press, 1994.

Viotti, Paul R. and Mark V. Kauppi, eds. International Relations Theory. Realism, Pluralism, Globalism. New York: Macmillan, 1987.

Voorhoeve, J.J.C. Peace, Profits and Principles. A Study of Dutch Foreign Policy. The Hague: Martinus Nijhoff, 1979.

Weber, Max. Essays in Sociology. New York: Oxford University Press, 1978.

Wels, C.B. ed. Vaderlands Verleden in Veelvoud. Opstellen over de Nederlandse geschiedenis na 1500. Deel II, 19e en 20e eeuw. Second revised edition: The Hague, 1980. 
Wels, C.B. Aloofness and Neutrality. Studies on Dutch Foreign Relations and Policy-Making Institutions. Utrecht: HES, 1982.

West, Richard. Tito and The Rise and Fall of Yugoslavia. London: SinclairStevenson, 1994.

Westerman, Frank and Bart Rijs, Srebrenica. Het zwartste scenario. Amsterdam: Atlas, 1997.

Wijk, Rob de, NATO on the Brink of a New Millennium: the Battle for Consensus. London: Brassey's, 1997.

Wolfers, Arnold. Discord and Collaboration. Baltimore: Johns Hopkins University Press, 1963.

Woodward, Bob. The Choice, New York, Simon \& Schuster, 1996.

Woodward, Susan. Balkan Tragedy. Chaos and Dissolution after the Cold War. Washington, D.C: Brookings Institution, 1995.

\section{Articles}

Barber, Lionel. 'Vegetable-Eater,' Financial Times, November 13, 1997.

Berdal, Mats. 'Fateful Encounter: the United States and UN Peacekeeping.' Survival, Vol. 36, No. 1, Spring 1994, pp. 30-50.

Berends, Ellen. 'De desintegratie van de Sovjetunie en de verantwoordelijkheid van het Westen,' Internationale Spectator, Vol. xlv, No. 7, July 1990.

Berends, Ellen and Harm J. Hazewinkel, 'Nederland en Oost-Europa.

Omzien in verwondering,' Internationale Spectator, 1992

Bleich, Anet. 'Safe havens in Bosnië: een zinnig voorstel', de Volkskrant, November 24, 1992.

Beugel, E.H. van der. 'Minister Beyen: persoonlijke herinneringen,' Internationale Spectator, February 1991, Vol. xlv, No. 2.

Beugel, E.H. van der. 'Nederland in de naoorloogse Westelijke samenwerking,' Internationale Spectator, March 1995, Vol. xlix, No. 3.

Beuningen, Frank van. 'Interimmanagement vanuit Den Haag. Nederland en het Voorzitterschap van de IGC', Internationale Spectator, September 1997 - li - 9.

Binder, David. 'Yugoslavia Seen Breaking up Soon. C.I.A. Paper Predicts Action in 18 months and Adds Civil War is Likely,' New York Times, November 28, 1990.

Briquemont, Francis. “'Doe iets, generaal”. De val van Srebrenica bewees de leugenachtigheid van peacekeeping in Bosnië,' De Morgen, January $9,1997$. 
Broek, Hans van den. 'Internationale betrekkingen: wetenschap en beleid,' Internationale Spectator, Vol. Xliii, No. 1, January 1989

Broek, Hans van den. 'Nederlandse betrokkenheid bij het vormgeven van een nieuw Europa,' Internationale Spectator, Vol. Xliv, No. 8, August 1990, pp. 449-456.

Doel, Theo van den, Dick Leurdijk and Joris Voorhoeve. 'Is er een duurzame oplossing voor de oorlog in Bosnië?', Internationale Spectator 47-6, June 1993.

Elgström, Ole. 'Active Foreign Policy as a Preventive Strategy Against Dependence,' Cooperation and Conflict, XVI, 1981.

Ermers, Marcel and John Kragt. 'Tussen tradities en tractaten: Minister Beyen van Buitenlandse Zaken en de Europese integratie,' Internationale Spectator, May 1991, Vol. xlv, No. 5.

Gelb, Leslie H. 'False Humanitarianism,' New York Times, August 6, 1992.

Glenny, Misha. 'Yugoslavia: The Great Fall,' The New York Review of Books, March 23,1995, pp. 56-65.

Glover-James, Ian. 'Powerful Kohl Club Closes the Door on Britain', Sunday Times, December 8, 1991.

Gompert, David. 'How to Defeat Serbia,' Foreign Affairs, Vo. 7,3 No.4, July-August 1994.

Gow, James. 'Deconstructing Yugoslavia,' Survival, Vol. XXXIII, no. 4.

Hazewinkel, Harm. 'Zelfbeschikkingsrecht en territoriale integriteit', Internationale Spectator, Vol. XLIX, No. 6. pp. 333-337.

Hehn, Paul N. 'The Origins of Modern Pan-Serbism - the 1844 Nacertanije of Ilija Garasaning: An Analysis and Translation.' East European Quarterly, Vol. IX, No. 2, pp. 153-171.

Heldring, Jerôme L. 'The Breznjev-doctrine van Jan Pronk,' NRC-Handelsblad, August 25, 1992.

Helm, Sarah. 'Dutch Resist the Second German Conquest,' Independent on Sunday, April 16, 1995

Hetzel, Helmut. 'In zwei Monaten entscheiden wir über die Anerkennung. Slowenien und Kroatien: EG-Ratspräsident Van den Broek konkretisiert im “Presse"-Gespräch das letzte Ultimatum,' Die Presse, October 18, 1991.

Hirsch, Mario. 'Influence Without Power: Small States in European Politics,' The World Today, March 1976.

Honig, Jan Willem. 'Myths That Keep Small Powers Going. Internationalist Idealism in the Netherlands,' Cyril Buffet and Beatrice Heuser. Haunted by History. Myths in International Relations. Providence/Oxford: Berghahn Books, 1998, pp. 15-27. 
Jansen Ds. Frans and Aalm. Harry Wanders, 'Het verantwoord risico. Uit liefde voor de medemens,' Kernvraag 1997/2, no. 112, pp.

Joustra, Wio. 'Kooijmans kiest voor voorzichtigheid. Navo gaat in de aanval, maar onder voorwaarden,' de Volkskrant, February 11, 1994.

Joustra, Wio and Hans Moleman. "Ik wil niet dat mijn mannekes risico lopen." Commandant is in Bosnië militair èn diplomaat,' de Volkskrant, January 28, 1994

Keohane, Robert O. 'The Big Influence of Small Allies,' Foreign Policy, No. 2, 1971.

Keohane, Robert O.'Lilliputians' Dilemmas: Small States in International Politics,' International Organization XXIII, No. 2 (1969).

Knapen, Ben. 'Wie bij de wereld wil horen, hoort nergens bij.' NRC Handelsblad, September 4, 1993.

Koch, Koen. 'Zeuren aan de zijlijn.' De Volkskrant, July 8, 1995.

Krasner, Stephen D., 'Structural Causes and Regime Consequence'. International Organization, 36, 2, Spring 1982.

Laan, Cees van der. "Srebrenica laat me niet meer los". Afgeschreven Minister Voorhoeve weet niet van opgeven'. Haarlems Dagblad, February $7,1998$.

Lindel, Ulf and Stefan Persson. 'The Paradox of Weak State Power,' Cooperation and Conflict XXI, 1986.

'Little countries. Small but Perfectly Formed,' The Economist, January 3, 1998, pp. 63-65.

Lubbers, Ruud. “'Drie keer” voordat de haan kraait,' Internationale Spectator, Vol. 1, No. 7/8, July/August 1996.

Meines, Rob. “'Als we niets doen, weten zeker dat het moorden doorgaat”; Rol EG bij de Balkancrisis begon zo mooi,' NRC Handelsblad, September 7, 1992.

Meines, Rob. 'Succes voor shuttlediplomatie Den Haag', NRC-Handelsblad, October 10, 1991.

Meulen, van der, Jan. 'Einde Missie?' Maatschappij en Krijgsmacht, Vol. 17, No. 4, August 1995, pp. 3-6.

Michielsen, Peter and Robert van de Roer. "Een onderhandelaar moet zijn gevoelens opkroppen"; Lord Owen blikt terug op rol in exJoegoslavië,' NRC-Handelsblad, June 10, 1995.

Neville-Jones, Pauline. 'Dayton, IFOR and Alliance Relations in Bosnia,' Survival Vol. 39, No.4, Winter 1996-97.

Newhouse, John. 'The Diplomatic Round. Dodging the Problem,' The New Yorker, August 24, 1992. 
Nieuwenhuis, Willebrord. 'Dupe van gewijzigde realiteit. Profiel van de Luchtmobiele Brigade,' NRC-Handelsblad, August 9, 1997.

Oppewal, Jolke and Didier Seroo. 'Dubbel interview met Hans van Mierlo en Jan Pronk, Internationale Samenwerking, March 1998, Vol.13, No. 3. Ornstein, Leonard. 'Het stratego van de experts,' Vrij Nederland, October 31, 1992.

Ornstein, Leonard and Maz van Weezel. 'Wereldse Zaken. Minister Kooijmans is best trots op "hummeltje Nederland", Vrij Nederland, April $16,1994$.

Pijpers, A. 'Dekolonisatie,' Internationale Spectator, February 1991-xlv-2.

Quiggin, Tom. 'Srebrenica en de internationale gemeenschap in Bosnië. Een samengebalde chaos?' Internationale Spectator, Vol. lii, No. 2, February 1998.

Review of International Affairs Documentation No 1007-8, 1. VIII-I.IX 1992, pp. 15-18.

Reijmerink, Marcel and Perry Pierik. 'Bij Defensie dienen alsnog koppen te rollen,' de Volkskrant, September 2, 1995.

Rozemond, S. De gang naar Maastricht. The Hague: Clingendael-notitie, October 1991.

Schaling, Frits. 'Christen-democratisch beraad over Euro-top', NRC-Handelsblad, November 27, 1991.

Schmelzer, Norbert W.K. 'De Mogelijke Invloed van de Kleinere Staaten in het Huidige Wereldbestel', Speech at Leuven, February 22, 1972. Netherlands Ministry of Foreign Affairs, Jaarboek 1971-72. The Hague: Staatsuitgeverij, 1972.

Schmelzer, Norbert W.K. 'Minister-president en buitenlands beleid,' Voor de eenheid van beleid: beschouwingen ter gelegenheid van vijftig jaar Ministerie van Algemene Zaken. The Hague: SDU, 1987.

Snyder, Glenn H. 'The Security Dilemma in Alliance Politics,' World Politics Vol. 36, No. 5, July 1984, p. 467.

Stabreit, Immo. 'Yugoslav Breakup: Don't Blame Germany,' Washington Post, June 29, 1993.

Staden, Alfred van. 'Small State Strategies in Alliances. The Case of the Netherlands,'

Cooperation and Conflict 1995. London, vol. 30 (1).

Staden, A. van. De fuik van Srebrenica, een bijdrage aan nadere oordeelsvorming The Hague: Clingendael Institute for International Relations, 1997. 
Stemerdink. A. 'Aardappels en gloeilampen: “it's the economy, stupid!", Hedendaagse diplomatie. Onmisbare schakel of overbodige luxe?. Internationale Spectator speciale editie. The Hague: Clingendael Institute, 1997.

Tharoor, Shashi. 'Should UN Peacekeeping Go "Back to Basics"?' Survival, Vol. 37, No. 4, Winter 1995-6.

Tiedeman, Elsbeth. 'Terug naar Zwarte Maandag. Hoe Duitsland op 30 september 1991 het Europees ideaal van Nederland om zeep hielp; een reconstructie met de hoofdrolspelers,' Elsevier, June 22, 1996.

Voorhoeve, J.J.C. 'Nederland: een middelgrote mogendheid in zakformaat,' Internationale Spectator, February 1991 - xlv-2.

Voorhoeve, J.J. C. 'Kansen voor Nederland,' Internationale Spectator, January 1993 - xlvii - 1.

Voorhoeve, J.J.C. and M. van den Doel. 'Nederland moet het initiatief nemen tot actie in Bosnië,' de Volkskrant, August 5, 1992.

Walker, Tom. 'Germany steps up pressure for union', The Times, November 27, 1991.

Wrede, Hans-Heinrich. "Friendly Concern.” Europe's Decision-making on the Recognition of Croatia and Slovenia,' The Oxford International Review, Vol. IV, No.2, Spring Issue 1993.

\section{Unpublished Papers}

Berghorst, Drea. Very Good News. De Besluitvorming over de uitzending van een luchtmobiel bataljon naar Bosnië-Herzegovina, MA thesis, 1996 NGIZ award, Free University of Amsterdam, July 1995.

Hagman. Hans-Christian. UN-NATO Operational cooperation in Peacekeeping 1992-1995. London: Department of War Studies, King's College London, 1996.

Hazewinkel, Harm J. 'Het Beleid ten aanzien van Joegoslavië, 1990-1993 (The policy with regard to Yugoslavia, 1990-1993). Internal History, The Hague: Ministry of Foreign Affairs, 1991.

Hulten, Michiel van. The Short Life and Death of the Dutch Draft Treaty towards European Union. Brugge: College of Europe, 1992/93. 


\section{Index of Names}

Abrams, Major 185

Adriatic Sea 190

Africa 108

Ahtisaari, Martti 151

Air Force, Royal Netherlands 190, 198, 236

Air Power 182, 185, 212-215, 217 , 223 (fn. 108), 238

Airmobile brigade 18, 184, 188, 190-191, 194-211, 217, 235239

Akashi, Yasushi 214

Albania 55, 227

Albright, Madeleine 155

Allison, Graham 29

Amsterdam 161

Andreotti, Giulio 131-132

Annan, Kofi 19

Arbitration commission; creation of 115-117

Argentina 187

Army, Royal Netherlands 198, 200- 201, 205, 209-211, 216, 236-237

Aspin, Les 20, 169-170

Austria 86, 126
Badinter commission: see under: Arbitration commission.

Badinter, Robert 136

Baker, James 16, 52, 85, 103, 125

Balkans 190

Baltic States 84, 91

Barth, Dirk 199, 203

BBC Newsnight 59

Beek, Relus ter 19, 20, 26, 52-53, 165, 190,194-196, 206-210, 236, 238

Beek, Relus ter, and the Switch 197-205

Beek, Relus ter, discusses air power with Boutros-Ghali 213-214, 223 (fn. 106)

Beek, Relus ter, meets Les Aspin 169-170

Beek, Relus ter meets BoutrosGhali in New York 204-205

Beek, Relus ter, visits Srebrenica 186

Belgium 17, 19, 82, 207

Belgium, and Dutch EC Presidency $104,111,116,123,131$, 134-135 
Belgium, as EC Presidency 158, $162,167-168$

Belgrade 16, 72, 83, 91, 92, 94, 102

Belgrade, EC/EU Ambassadors 62, 73, 74, 90

Belgrade, Netherlands Embassy $56,71,86,96,98,112,134,234$

Berends, Ellen 75, 76, 77, 79

Berlin, CSCE summit 15, 86, 95

Biegman, Niek 153-154

Bihac, safe area 196

Bonn 120, 124, 132, 155

Bonn, Netherlands Embassy 18, $120,132,158,193$

Borovo Selo, 69, 92

Bosnia-Herzegovina 17, 18, 20, $33,72,74,105,112,131,134-$ 135, 139 (fn. 11), 143-179, 190, 194, 198, 208, 212, 225, 228, 236

Bosnian Croats 20, 143-144, 151, $161,163,172,175,230$

Bosnian government 19-20 144, $146,151,161,167-168,171$ $172,175,188$

Bosnian Muslims (Bosniacs) 17, 20, 21, 106, 143-144, 146, 151, 154-155, 156-157, 161, 164, $165,167,171-173,175,191$, 205, 229, 181, 186, 188, 198, 206, 217, 230, 239-240

Bosnian Serbs 17, 21, 143-144, 151-152, 156, 158-159, 161, $163,171,175,181,188,215$, 217, 229

Boutros-Ghali, Boutros 19, 20, 213-214

Breemen, Henk van den 202-203
Brinkman, Jan Willem 201, 207208

Brioni 16, 105-107, 112, 136, 227228

Briquemont, Francis 181-182, 208

Britain, British (see also under: UK) $16-18,21,28,29,33,34$, 65, 148, 150, 152, 157-159, 161-162, 173-174, 183, 185, $192,212,226,229,233,238$ 239

Britain, and Dutch EC Presidency 104, 111, 115, 121, 123, 133, 135

Broek, Hans van den 16-18, 33, $52,145,154,198,226-229$

Broek, Hans van den Broek, as EU Commissioner for External Relations 152, 158

Broek, Hans van den, and August 27 declaration 114-117

Broek, Hans van den, and bilateral talks in Washington D.C 103 Broek, Hans van den, and border changes proposal 107-109

Broek, Hans van den, and Dutch EC Presidency 101-141

Broek, Hans van den, and early warning 76, 79, 81-82, 84-86, $88,94,97,239$

Broek, Hans van den, at London Conference 148-151

Brussels 109, 115, 131, 152

Brussels, Netherlands Permanent Mission to NATO 56, 193

Bucharest 81

Bureaucratic Politics model 2930, 184, 233-239 Bush, George 71, 95, 134 
Cabinet 50-53, 147, 152, 165, 190, $195,200,208,237-239$

Cambodia 199, 201

Canada, Canadian 87, 185, 187, 212, 230

Carr, E.H. 39

Carrington, Peter Lord 16, 56, $119,122-127,134,135,227-$ 228

CDA (Christian Democrats) 18, 48, 147, 191, 199, 205, 237

Central Bosnia 186-187, 205-207, 239

CFSP (Common and Foreign

Security Policy) 32-33, 59-63, 171

Chief of the Defence Staff, Ministry of Defence 57-58, 197,199, 202, 210

Christian-Democrats (see under: CDA)

Christopher, Warren 18, 156-159, 173,230

Clingendael Institute of International Relations, The Hague $18,39,166$

Clinton, Bill 18, 152, 154, 193

CNN 59

Coalition logrolling 29, 184, 209215, 235-239

Commander of Land Forces 57 58, 197

Contact Group 33, 65, 173-174, 183, 233

Copenhagen 19, 158, 162-163, 195-196, 203-204

CoPo (see also under: Political

Committee) 93, 114, 166

Cot, Jean 182, 208
Couzy, Hans 19, 20, 57, 188, 200, 203, 207-208, 215

COWEB 62

COYUG 62, 166

Croatia, Croatian 16, 17, 19, 69, 71, 72-74, 82, 86, 92, 93, 95, 101-141, 144, 161, 166, 198, 207, 226-227, 231, 234-235, 239-240

Croatian Serbs 73, 82, 106, 107 108,114

CSCE $15,70,79-80,87-88,97$, $110,112,135,234$

D66 48, 52, 211

$D A B$ (Department of General Policy Affairs), Ministry of Defence 53, 57-58, 197, 199200, 203

DAV (Department of Atlantic Security and Cooperation Affairs, Foreign Ministry) 55, 56, 58, 79-80, 109, 111-112, 156-157, 165, 168, 199, 215

Dayton 230

De Hoop-Scheffer, Jaap 147

De Volkskrant 50, 206, 213

Defence Staff 207-208

Denmark and Dutch EC Presidency 104, 108

Denmark, Danish 92, 116, 134135, 158, 206, 228

Department of Information, Ministry of Defence 57, 185, 205

DGES (Director(ate)-General for European Affairs, Foreign Ministry) 54-55 
DGIS (Director(ate)-General for International Cooperation,

Foreign Ministry) 54-55

DGPZ (Director(ate)-General for

Political Affairs, Foreign

Ministry) 54-55,75, 79, 80, 81, 96, 107, 114, 167-168, 199, 234

DGRB (Director(ate)-General for

Regional and Country Policy

Affairs, Foreign Ministry) 5455

Die Presse 126

Dijk, Colonel van 185

Dobbins, James 15, 83, 90, 94

Doel, Theo van den 18, 147, 166

Dubrovnik 101, 127-128, 138

Dumas, Roland 115-117, 125, 128

$D V B$; see under: DAV

Eastern Bosnia 143-144, 157, 171, $176,182,185,234,238$

Eastern Europe division, Foreign Ministry 55, 75-77, 109, 111, 113

Eastern Europe working group 62, 91-92

EC (Peace) Conference, creation of 115-117

EC (Peace) Conference 16, 18, 119, 121-124, 125, 127-128, 227-228, 232

EC Presidency, Dutch 16, 33, 34, $35,40,55,96,101-141,225$ 227, 232, 234, 239

EC/EU 17, 20, 28, 30, 41, 71, 73, 154-155, 160, 164, 166, 168, 173-174, 226-228, 230-235, 240
$\mathrm{EC} / \mathrm{EU}$, and early warning 76,77 , 80, 81, 83-85, 89-94, 96

ECMM (EC Monitoring Mission) 105, 111, 112, 114, 226

Eekelen, Willem van 110

Eenennaam, Boudewijn van 109, 124, 127, 165, 199

Eichenberg, Richard 50

Elgström, Ole 39

Elsevier Magazine 197

Entrapment 30-32, 41, 157, 176, $215,225,239-241$

Entrapment, military 181-223

Entrapment, moral and political 143-179

EPC (European Political

Cooperation) 59-63, 70, 83, 85, 87, 89-94, 166, 170

EPP (European Christian

Democrats) 17, 63, 82, 131-

12, 141 (fn. 58)

EU Action Plan 19, 167-173, 175, 229-230

European Affairs Department, Foreign Ministry 25, 55, 56, 161,170

European Commission 86, 90, $116,119,173$

European Council of Heads of

State and Heads of

Government 60, 62, 93, 195196

Everts, Philipp 49

Eyskens, Mark 82

Fietelaars, Jan 15, 73-75, 77, 86, $95,98,112,127$

France 16, 18, 33, 34, 56, 65, 86, 90, 150, 152, 157-161, 167-168, 
173-175, 183, 192, 196, 212,

226, 229-230, 233, 238-239

France, and Dutch EC Presidency

104, 110-111, 115-117, 118,

121, 133-137

Frankfurt 163

Frankfurter Allgemeine Zeitung

33, 118

GAC (General Affairs Council of EC/EU Foreign Ministers) 61, $89,115,131,158,168,171$

Geneva Conventions 149

Geneva, ICFY negotiations 162,

164

Genscher, Hans-Dietrich, and

August 27 declaration 114-

117

Genscher, Hans-Dietrich 17, 52,

104, 118, 120, 122, 125, 128,

132

Germany, and Dutch EC

Presidency 101-141

Germany, and early warning 75-

$76,87,90-92$

Germany, German 17, 19, 34, 65,

71, 73, 162, 163, 166, 167-168,

173-174, 183, 196, 227-229, 233, 239

Glina 69

Goldstein, Judith 30

Gompert, David 78

Gorazde 20, 21, 143, 215, 223 (fn. 108), 238-239

Goulding, Marrack 130

Gow, James 32-33, 34, 182, 231

Greece, Greek 86, 90, 116, 131, 135, 196

Gulf conflict 71
Haarzuilens castle 16, 125, 128

Haiti 169

Halilovic, Sefer 144

Halle 118

Halperin, Morton 29

Handel, Michael 28

Hasselman, Dirk 73, 74

Hayes-Renshaw, Fiona 61

Hazewinkel, Harm 74-77, 79, 82

Heldring, Jerôme 147, 189

Helsinki, Final Act 87, 92

Heuven, Marten van 71

Hoekema, Jan 50, 148, 153, 163, 204

Honig, Jan Willem 25

Hungary 86

Hurd, Douglas 121, 125

ICFY (International Conference on Former Yugoslavia) 18, 19, $33,41,195,232$

ICFY, peace plans 143-179, 189190

Ideas and beliefs approach 30 , 225, 233-239

Igman, Mount 213

International Court of Justice 153

International Herald Tribune 18, 59

International Organisation 28

Internationale Spectator 166

Ireland, Irish 116, 135, 196

Italy, Italian 16, 65, 173, 196, 233

Italy, and Dutch EC Presidency $104,116,120,122,131,134$ 135

Italy, and early warning 83,86 , 90, 94

ITN 17, 145 
Izetbegovic, Alija 20, 139 (fn. 11), 163, 166

JAP (Joint Action Programme) $18,33,65,159-160,163,174$, 183,233

JNA (Yugoslav People's Army) 16, 74, 93, 101, 104, 110, 112, 114, $117,124,126-128,130,227$

Jordania 187

Juppé, Alain 19, 160, 167, 191, 230

Kadijevic, Veljko 16, 124

Kakanj 207

Kamman, Curtis 94

Karadzic, Radovan 18, 151, 158, 212

Keohane, Robert 27, 30

Keraterm 146

Kinkel, Klaus 19, 20, 163-164, 167,172

Kiseljak 208

Koch, Koen 216

Kohl, Helmut 93, 118, 131-132

Kok, Ton de 205

Kok, Wim 50, 53, 238-239

Kolsteren, Ton 20, 186-187, 21

Kooijmans, Pieter 18, 19, 20, 52, 153-154, 195-196, 197, 204, 213, 230

Kooijmans, Pieter, and ICFY peace plans 143-179

Kooijmans, Pieter, and safe areas 189-197

Kooijmans, Pieter, discusses air power with Boutros-Ghali 213-214, 223 (fn. 106)
Kooijmans, Pieter, discusses military options with Ter Beek 199

Kooijmans, Pieter, meets Haris Silajdzic 170-171

Kooijmans, Pieter, meets Warren

Christopher 158-159, 192-193

Kooijmans, Pieter, receives Owen and Stoltenberg 163-164

Kosovo 25, 48, 69, 72-73, 108, 149,238

Krajina 107

Kröner, Christiaan 108-109, 112

Lake, Anthony 204-205

Lebanon 192

Leiden, University of 52, 153

Lepick, Olivier 33

Libal, Michael 108

Liberalism 28, 31, 38

Little, Alan 35, 105-106, 149, 226, 229

Ljubljana 83,86

Logistical unit 194-205

London Conference, August 1992 17, 20, 34, 26, 148-151, 153, $162-163,165,169,174,229$, 233, 240

London 155, 185

Lubbers, Ruud 20, 40, 81-82, 93 , 118-119, 131-132, 189, 195196, 198, 213

Lubbers, Ruud, discusses air power with Boutros-Ghali 213-214

Luxembourg 16, 63, 74, 196

Luxembourg EC Presidency 76, $83,86,89,93,94$ 
Luxembourg, and Dutch EC

Presidency 103-104, 116, 123, 131, 139 (fn. 11)

Maastricht IGC 17, 52, 80, 89, 133, 135

Macedonia, Former Yugoslav

Republic of 17, 72, 74, 131

Maintenance unit 194-205

Majoor, Frank 54, 165

Major, John 148, 150

Marines, Royal 199, 201

Markovic, Ante 76, 81

Martens, Wilfried 131

Media 59, 177 (fn. 9), 235, 240

Meier, Viktor 33-34, 72, 105, 118, 121-122, 226

Mesic, Stipe 15, 70, 92, 103

Michelis, Gianni de 94, 116, 120, 125, 135

Michielsen, Peter 234

Mierlo, Hans van 52, 188, 211, 238-239

Milosevic, Slobodan 16, 69, 74, $103,113,124,126,127,128$, 139 (fn. 11), 145

Ministry of Defence 41, 56-58, 147, 183-237

Ministry of Defence, sets a price 209-215

Ministry of Foreign Affairs 41, $147,150,161,163,165,167-$ $168,171,176,183-198,204$, 210-218, 223 (fn. 108), 227, 230, 234-239

Mitsotakis, Konstantin 131

Mitterrand, François 93, 196

Mladic, Ratko 144, 182

Mondorf-les-Bains 76
Montenegro 72, 101, 114, 116, $169,227-228$

Morillon, Philippe 143-144, 185

NATO 20, 29, 34, 46, 48, 52, 53, $63,64,70,75,78-79,85,87,96$, $102,110-111,121,123,169$ $170,186-187,190,194,210-$ $215,226,230,238$

NATO, ministerial meetings 18 , 20, 64, 128, 157, 169-170, 187, 213

Navy, Royal Netherlands 190, 236

Netherlands, historical background 45-48

Netwerk 59

New York 19, 125, 126, 150, 154, 182, 191-192, 202, 204

New York Review of Books 59

New York, Netherlands

Permanent Mission to the UN 56, 193

NIOD (Netherlands Institute for War Documentation) 10, 26

No-Fly Zone 190, 198

Nooij, Albert 15, 72, 75

Nordic countries (see also under: Scandinavian countries) 196, 207

Norway, Norwegian 161, 206

NOVA 59

NRC Handelsblad 46, 50, 147, 234

Omarska 146

OSCE 55, 64, 70, 230

Osijek 130

Owen, David Lord 26, 33, 151, 155-156, 159, 161-164, 166, 171,229 
Owen-Stoltenberg plan: see under: Union of Three Republics.

Pakistan, Pakistani 19, 202

Pakrac 69

Pale 21, 215

Paris, Charter of 88

Paris 126, 153, 155

Parliament (see also under:

Second Chamber) 41, 48-50, 147, 154, 164, 183, 189, 199, 203-206, 209-211, 215, 235237

Perez de Cuellar, Javier 134

Perry, William 205

Peterle, Lojze 15, 81, 83

Pinheiro, de Mr. 116

Plitvice National Park 69

Poland 170, 187

Political Committee (see also under: CoPo) 15, 62, 75, 81, 90-91, 134-135, 171

Poos, Jacques 15, 94, 103

Portugal 94, 116, 135, 162

Prlja, Dr 72

Pronk, Jan 17, 54, 146, 165, 189

Public opinion 59, 177 (fn. 9), 215, 235, 239

PvdA (Labour) 18, 48, 146, 191, 199-201, 206-207, 237

Rapid Reaction Force 48 Realism, Realists 27-30, 36, 189, 225

Regime-theory, regimes 28,70 , 96, 137, 167, 174, 231-234

Reitsma, Ruurd 20, 203, 208-209

Renssen, Raviv van 184
Rome 89, 128

Rupel, Dimitrij 15, 69, 81, 86

Russian Federation 18, 34, 60, 65, 159, 172-174, 183, 192, 214, 233

Sacirbey, Mohamed 187, 191-192

Safe areas 144, 145, 159-160, 166, 169, 170-171, 173, 175-176, 181-184, 189-197, 216-218, 230, 233-236, 240

Santer, Jacques 131

Sarajevo 21, 172, 196, 208, 213

SAS (Special Air Service) 187

Scandinavian countries (see also under: Nordic countries) 206207

Schaper, Herman 79-80, 102

Scheffer, Paul 46

Schiphol airport 130

Schoo, H.J. 197

Schouten, Maarten 201-202

Scowcroft, Brent 16, 103

Second Chamber (see also under: Parliament) 186-198, 205-210, 236

Security Council 17, 18, 25, 35, 56, 63-65, 128, 130, 134, 144, 148-149, 158-160, 169-170, 181-183, 189-193, 212, 214, 230-238

Separovic, Zvonimir 16, 119

Serbia $34,70,72,74,91,102,106$, 109, 110, 112, 114, 116, 117, $124,125,127-128,129,130$, 144-145, 148-149, 161, 166, $169,186,227-228,235$

Seville 187

Silajdzic, Haris 20, 170-171 
Silber, Laura 35, 105-106, 149, 226, 229

Simon, Herbert 29

Skof, Matija 83

Slovenia, Slovene 16, 17, 69, 7274, 76, 81-83, 86, 91, 93, 95, 101, 105-106, 110, 112, 117, 120-122, 124-126, 130-131, 133-136, 138, 226-227, 231, 239-240

Small State theory 27, 35, 36, 37, $38,39,40,148,160,175,225$ 230

Snyder, Glenn 31

Social-Democrats: see under: PvdA

Soviet Union 71, 78-79, 84-85, $88,91-92,94,108,113,133$ Spain 18, 33, 86, 116, 135, 159, $162,192,212,233,238$

Srebrenica 20, 21, 25, 26, 31, 34, 48, 49, 143-144, 157-158, 176, 181-189, 205-213, 215-216, 230, 240

Stability Pact 55

Stichting Maatschappij en

Krijgsmacht 59

Stoel, Max van der 46

Stoltenberg: Thorvald 161, 163164, 166

Stuyvenberg castle 17, 131

Sun Tzu 189

Sweden 206

Switch, the Defence Ministry's 197-205

Tas, Jan van der 120, 132
TCBU (Tijdelijke Commissie Besluitvorming Uitzendingen)

9-10, 145, 189, 218 (fn. 8)

Teltschick, Horst 118

TEU (Treaty on European Union)

$32,52,60,62,133$

The Economist 28, 59

The Hague 152, 155-156, 162,

$184,213-214,234$

Thorbecke, J.R. 38

Tito 201

Traa, Maarten van 191, 206, 235

Transport battalion, Belgian-

Dutch 198, 205, 207, 236

Troika 15, 34, 83, 94-95, 103, 158-159

Trouw 17

Tudjman, Franjo 16, 72, 106, 113, 124, 139 (fn. 11)

Tuzla 206

Ukraine $60,91,187$

UN 18, 33, 40, 56, 64-65, 87, 121 , $125,130,131,135,145-146$, 148, 150, 155, 159, 161 170, $173,175-176,182-183,190-$ 195, 199-205, 212-215, 233, 236

UN Affairs Department, Foreign Ministry 56, 148, 193, 204, 215, 220 (fn. 35)

UN High Commissioner for Refugees 150

UNIFIL 49, 192 Union of Three Republics plan 19, 161-167, 183, 195, 205, 229, 233, 235, 240

United Kingdom (UK): see under: Britain, British. 
United States, American 15-18, 19, 27, 29, 34, 37, 52, 63, 65, 71, $152,155-161,166,168-169$, 172-174, 183, 193, 204-205, 212-213, 229, 233

United States, and Dutch EC

Presidency 101, 102, 110, 113, 121, 123, 137

United States, and early warning $78,79,80,81,83,86-88,90,94$ $96,97,231,239$

UNMOs (United Nations Military Observer) 15, 215

UNPROFOR 17-19, 21, 143-144, 161, 181-182, 186, 193, 198, 202, 206-209, 212-215, 236, 238,240

Valk, Gerrit 206

Vance, Cyrus 130, 134, 151, 156, 159,161

Vares 207

Venice 16, 120, 122

Vermeulen, Chris 184-185

Vernon, Chris 238

VJ (Yugoslav Army) 144-145

Vlis, Arie van der 18, 200, 202204, 210-211, 217

Vojvodina 72

Voorhoeve, Joris $18,20,27,39,54$, 147, 165-166, 218 (fn. 8), 238239

Voorhoeve, Joris: discusses options 187-188

Voorhoeve, Joris: visits Srebrenica 186

VOPP (Vance-Owen Peace Plan)

18, 151-161, 183, 191-192, 194, $199,229,233,235,240$
Vos, Joris 167, 169

Vrij Nederland 129

Vukovar 16-17, 101, 112-113, 127, 129-130, 138, 145-146

VVD (Conservative liberals) 48, 147,239

Wallace, Helen 61

Walsum, Peter van $15,17,113$ 114, 124, 127, 130, 199, 227

Walsum, Peter van, and August 27 declaration 114-117

Walsum, Peter van, and bilateral talks in Washington D.C 103 104

Walsum, Peter van, and border changes proposal 107-109

Walsum, Peter van, and early warning $80,81,82-83,84,89$ 91

Walsum, Peter van, and memorandum on selective approach 129

Waltz, Kenneth 27, 225

Washington, D.C. 15, 18, 19, 83, 103, 169, 204-205

Welch Fusiliers 238 WEU 16, 55, 63, 79, 110-111, 121, $132,136,137,190,226$

Wijnaendts, Henry 56, 112, 119, $124,126,127,153,228$

Woodward, Susan 34, 35

Wrede, Hans-Heinrich 117 WTO (World Trade Organisation) 29

YPR armoured vehicles 203, 211 Yugoslavia, Federal Republic of 
(Serbia and Montenegro) 63, 101, 114, 116, 169, 200

Yugoslavia, Socialist Federative

Republic of 32, 55, 69, 71, 76-

77, 79, 81, 82, 85, 89-90, 91, 92,

$94,97,103,105,112,128$

Zagreb 16, 19, 20, 72, 86, 94, 103, 207-208

Zenica 205, 207

Zepa 143-144, 208-209 